University of Louisville

ThinkIR: The University of Louisville's Institutional Repository

$5-2004$

\title{
Child maltreatment assessment and recidivism : a study of Kentucky child protective services.
}

Helen Katherine Mudd

University of Louisville

Follow this and additional works at: https://ir.library.louisville.edu/etd

\section{Recommended Citation}

Mudd, Helen Katherine, "Child maltreatment assessment and recidivism : a study of Kentucky child protective services." (2004). Electronic Theses and Dissertations. Paper 1019.

https://doi.org/10.18297/etd/1019

This Doctoral Dissertation is brought to you for free and open access by ThinkIR: The University of Louisville's Institutional Repository. It has been accepted for inclusion in Electronic Theses and Dissertations by an authorized administrator of ThinkIR: The University of Louisville's Institutional Repository. This title appears here courtesy of the author, who has retained all other copyrights. For more information, please contact thinkir@louisville.edu. 
CHILD MALTREATMENT ASSESSMENT AND RECIDIVISM: A STUDY OF KENTUCKY CHILD PROTECTIVE SERVICES

By

Helen Katherine Mudd

B.S., Eastern Kentucky University, 1976

M.S., Eastern Kentucky University, 1979

M.S.S.W., University of Louisville, 1990

\author{
A Dissertation \\ Submitted to the Faculty of the \\ Graduate School of the University of Louisville \\ in Partial Fulfillment of the requirements \\ for the Degree of
}

Doctor of Philosophy
Kent School of Social Work
University of Louisville
Louisville, Kentucky
and
College of Social Work University of Kentucky
Lexington, Kentucky

May, 2004 
CHILD MALTREATMENT ASSESSMENT AND RECIDIVISM: A STUDY OF KENTUCKY CHILD PROTECTIVE SERVICES

By

Helen Katherine Mudd

B.S., Eastern Kentucky University, 1976

M.S., Eastern Kentucky University, 1979

M.S.S.W., University of Louisville, 1990

A Dissertation Approved on

April 7, 2004

By the following Dissertation Committee:

Thomas R. Lawson, Ph.D., Dissertation Director

Ruth Huber, Ph.D.

Dana Christensen, Ph.D.

Gerald Barber, Ph.D.

Pat Litzelfelner, Ph.D. 


\section{DEDICATION}

This dissertation is dedicated to

Herman and Pauline Brown

and

Paul and Helen Taylor

who have provided me with lifelong support in my educational endeavors. 


\section{ACKNOWLEDGMENTS}

I would like to thank the chairman of my qualifying exams and dissertation committee, Dr. Thomas Lawson, for his guidance and patience. I am particularly thankful for Dr. Lawson's assistance with my statistical analysis. I would also like to thank my other committee members, Dr. Ruth Huber, Dr. Dana Christensen, Dr. Rod Barber, and Dr. Pat Litzelfelner for their unique contributions to my studies. I offer special thanks to Dr. Ruth Huber, the director of the Kent School Doctoral Program, whose patience, wisdom, and compassion have guided me throughout this journey. I am indebted to Dr. Dana Christensen for his contributions to Kentucky's Solution-Based Casework. As a Kentucky protective service worker, solution-based casework has provided me a theoretical foundation for my work with families and children. It has also provided structure for my educational endeavors. I would also like to express my appreciation to $\mathrm{Dr}$. Rod Barber for his contributions to Kentucky's All Families Matter Data. Dr. Barber's work in Kentucky child welfare outcomes has been instrumental in changing the way I, as well as our state, evaluates our work with the families we

serve. I offer my appreciation and thanks to Dr. Pat Litzelfelner, whose comments on safety at the defense of my dissertation proposal provided needed focus to my studies. I especially appreciate Dr. Litzelfelner's willingness to travel many miles to actively participate in my qualifying and dissertation committees. 
Being a member of the charter class of the Kent School of Social Work

Doctoral Program has been a life altering experience. My expressions of appreciation would not be complete, therefore, without recognizing my fellow charter class members-Iris Phillips, Nancy Keeton, Linda Taylor, and Bart Irwin. I offer them thanks for being my travel companions on this journey. The memories of our shared experiences will always be remembered with fondness.

During my tenure with the Commonwealth of Kentucky, I have had the opportunity to work with a dedicated and caring staff that works tirelessly on behalf of the children they serve. Their efforts are making a difference. I therefore, offer them my thanks, especially to Unit 1, Hardin County.

Last, but certainly not the least in importance, I offer my appreciation to my family. Words are not adequate to express the depth of my appreciation to my husband, Lenny, for his understanding and patience during those times when the journey was long and the end was almost unperceivable. His love, encouragement and unwavering support carried me through the difficult times of this journey. Also, thanks to my children, Kristi Keeling, Kimberly Mudd, Stephen Mudd, and Katie Mudd whose belief in their mother was a constant source of inspiration. I offer special thanks to Kimberly Mudd for her assistance in data entry. In closing, I acknowledge immeasurable gratitude to Herman Brown, Pauline Brown, Paul Taylor, and Helen Taylor, my parents, my uncle, and my aunt, who have provided me with a lifetime of love and support. Their neverending belief in my ability gave me the courage to begin and finish this long, difficult, and challenging journey. 


\section{ABSTRACT}

Child Maltreatment Assessment and Recidivism:

A Study Of Kentucky Child Protective Services

Helen K. Mudd

May 8,2004

This quantitative dissertation examines risk assessment and recidivism of child maltreatment to determine the relationship between child protective services provided by the Kentucky Department of Protection and Permanency and risk of harm. A chart review of existing data on 3,235 closed Kentucky child protective services cases provides information about the quality of service provided to families, the reduction of risk of maltreatment assessed in the family, and the rate of recidivism following case closure. This dissertation examines the usefulness of the Continuous Quality Assessment tool (CQA) and its effectiveness in assessing risk. The CQA is an assessment tool that is designed to guide child protective workers in making case decisions throughout the life of the case. This dissertation on risk assessment and recurrence of maltreatment adds to the measurable outcomes of effectiveness for child protection services and enhances a public child welfare agency's ability to improve service delivery to families. 
A modified one-group pretest posttest design was utilized to assess the dependent variables, risk of maltreatment and recurrence of maltreatment, before and after casework services were provided. Changes in risk of maltreatment were measured by the cumulative rating on the assessment tool, as well as by scores in the specific risk domains: maltreatment, sequence of events (how well the family is managing their high-risk situations), family development stages, family choice of discipline, adult patterns of behavior, child/youth development, and family support. The second dependent variable, recurrence of maltreatment, was measured by the number of reports of maltreatment investigated in the year following case closure.

Findings highlight the success of solution-based casework in creating change. Variables found to be significantly related to reduction in risk include (a) the length of time a case was open for the current treatment episode, (b) region of service, (c) supervisor gender, (d) CQA individual risk domains, and (e) expertise of worker. Variables found to be significantly related to recurrence of maltreatment include (a) CQA safety rating and individual risk domains, (b) worker's level of skill, (c) type of abuse, (d) number of substantiated referrals in case at closure, $(\mathrm{f})$ a prior episode of treatment, and $(\mathrm{g})$ geographic region of service. 


\section{TABLE OF CONTENTS}

PAGE

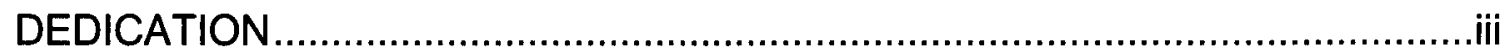

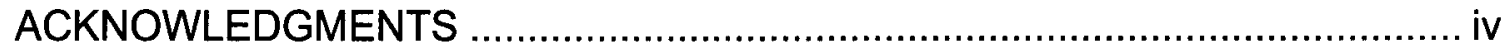

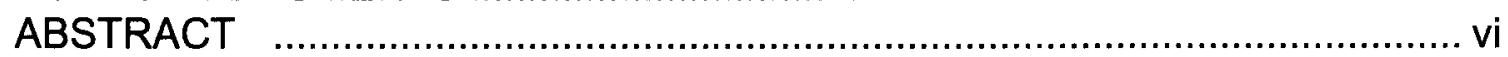

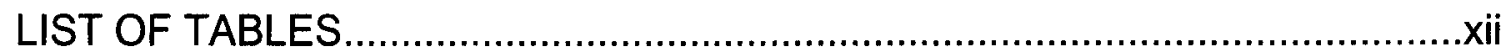

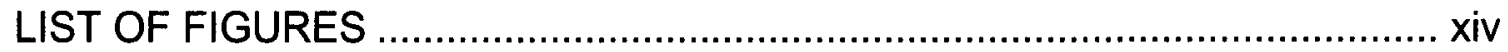

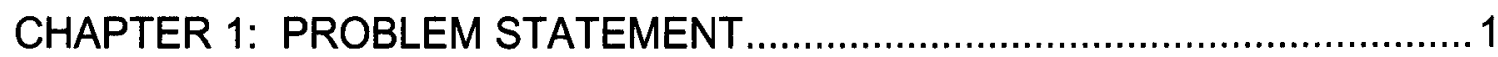

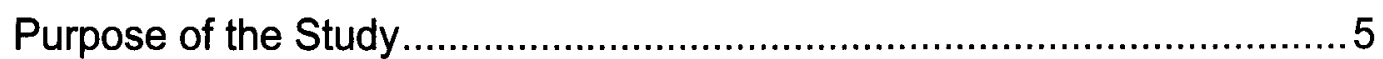

Child Welfare Outcomes and Overarching Research Question.......6

Continuous Quality Assessment............................................ 6

Supporting Standards of Accreditation and Cabinet Outcomes ......8

Child Welfare Services Defined ......................................................... 9

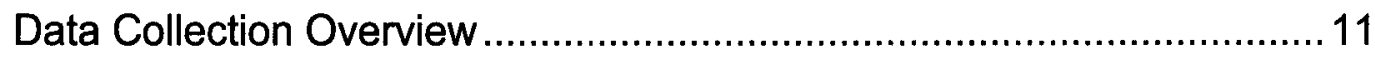

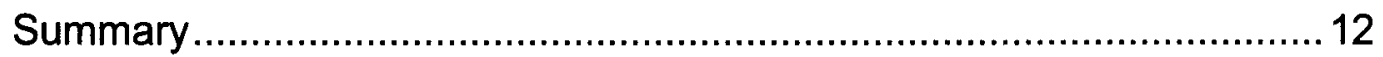

CHAPTER 2: LITERATURE REVIEW ................................................. 13

Historical Context of Child Abuse ......................................................... 13

Effectiveness and Outcome Measurement in Child Welfare .................. 24

Risk Assessment in Child Protective Services .................................... 42

Paradigm Of Risk Society ......................................................... 43

Risk Assessment Decision-Making ............................................. 44

Defining Child Well Being ........................................................ 45 
The Cycle of Abuse

Life Events and Environmental Factors ................................. 47

Risk Assessment to Improve Clinical Judgment ....................... 49

Assessment Tools .................................................................. 51

Summary of Risk Assessment in Child Protective Services ........ 54

Nationwide/Kentucky Child Abuse Statistics ...................................... 55

Kentucky's Solution Based Casework .............................................. 61

Summary of Literature Review ....................................................... 63

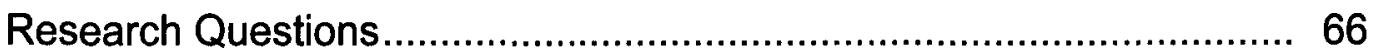

CHAPTER 3: METHODOLOGY .......................................................... 67

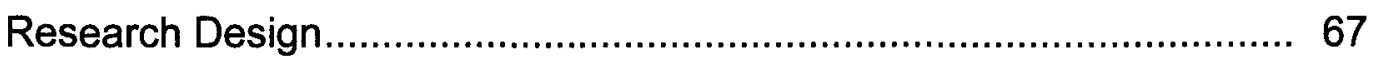

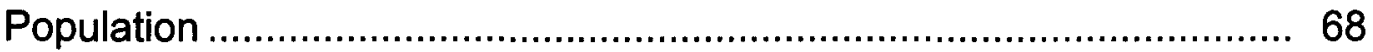

Dependent and Independent Variables ............................................. 70

Data Collection and Research Instruments ....................................... 72

Issues of Confidentiality/Informed Consent ........................................ 74

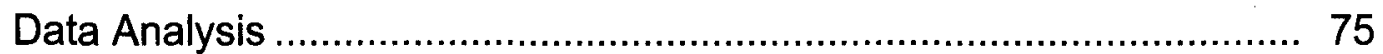

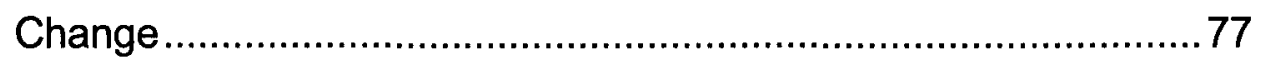

Repeat Maltreatment ............................................................ 78

Case Manager Demographics ..................................................79

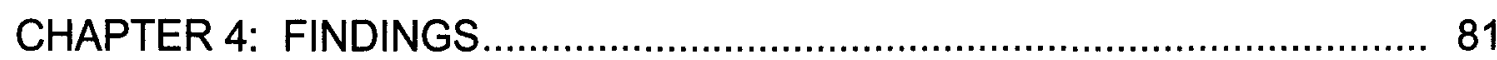

Demographics: Kentucky and Study Populations............................. 81

Change: Research Question One ............................................ 86

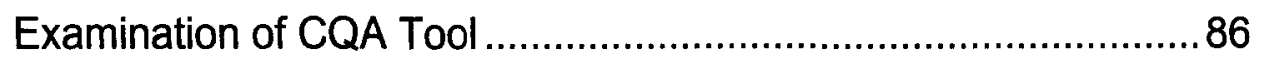


Tests Of Significance For Change Between Opening and 93

Closing

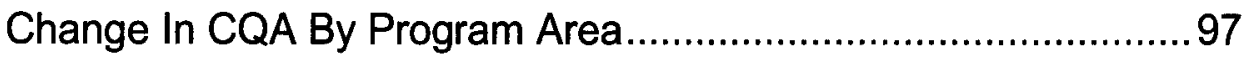

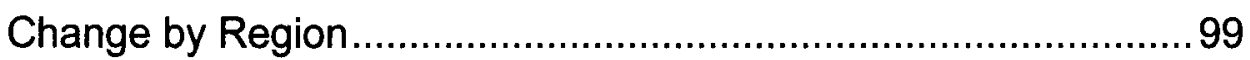

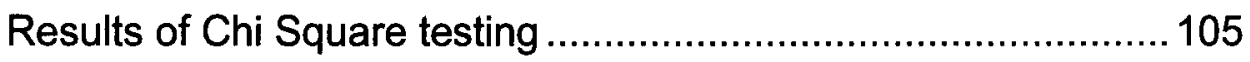

Restatement of and Answer to Question One .......................... 106

Repeat Maltreatment: Research Questions Two and Three ............... 120

Cases With Prior Treatment Episode .................................... 120

Referrals Since Case Closure ................................................. 124

Results of Chi Square testing ................................................ 128

Restatement of and Answers to Questions Two and Three ........128

Case Manager Demographics: Research Questions Four and Five .....139

Demographics of population ..................................................140

Restatement of and Answers to Questions Four and Five ..........144

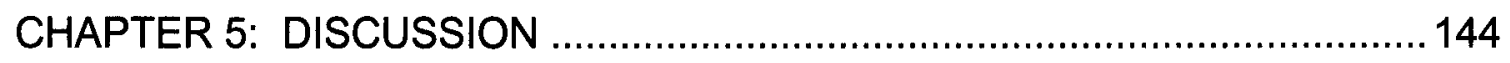

Continuous Quality Assessment Tool .............................................. 150

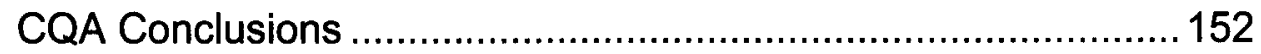

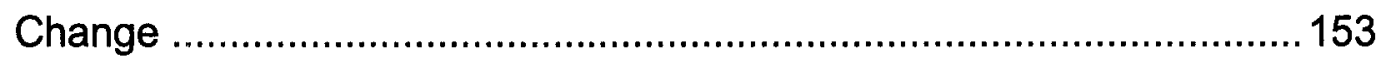

Confirmation of Change by Paired t-testing .............................. 154

Regional Differences in Change ............................................ 154

Significant Relationships Between Independent Variables.......... 155 And Change

Case Manager/Supervisor Demographics Related to Change .... 157 
Regional Differences in Maltreatment.

Significant Relationships Between Independent Variables 159 and Repeat Maltreatment

Case Manager/Supervisor Demographics Related to Repeat..... 162 Maltreatment

Limitations 163

Concluding Comments on Assessment, Change, and Recidivism 164 With Suggestions For Future Studies

CQA Tool 164

Change 165

Recidivism 166

Effectiveness in Kentucky? 167

REFERENCES 169

APPENDICES 184

CURRICULUM VITAE 218 


\section{LIST OF TABLES}

TABLE

PAGE

1. Number of Child Victims of Physical Abuse, Sexual Abuse and Neglect....58

2 Distribution of Recurrence of Maltreatment 2001 by Region......................60

3. Dependent and Independent Variables, Operationally Defined with ...........71 Level of Data

4 Distribution of Cases by Region with Regional Demographics .................. 83

5. Differences Between Huebner's (2002) and Mudd's (2004) Factor ............89 Analyses of Risk Factors

6. Crosstabulation of Risk at Case Opening by Risk Fields .........................99

7. Crosstabulation of Risk at Case Closure by Risk Fields ..........................93

8. Crosstabulation of Risk at Case Opening by Huebner Safety Factor, .......94 Mudd Safety Factor and Huebner Well Being Factor

9. Crosstabulation of Risk at Case Closure by Huebner Safety Factor, .........95 Mudd Safety Factor and Huebner Well Being Factor

10. Paired t-test Analyses Comparing Changes in Risk Factors and .97 Cumulative Scores Between Opening and Closing

11. Correlations Between CQA Risk Factors and Change in CQA Score. .97 Between Opening and Closing CQA

12. Mean Frequency Scores for Change Between CQA Opening and .98 Closing Scores by Primary Program Area

13. Paired t-test Analyses Comparing Changes in Scores on CQA by 99 Program Area

14. Frequency Scores in Means of Change and Months of Service Case .....100 Open for Current Treatment Episode 
15. Paired t-test Analyses Comparing Changes in Scores on CQA 101 by Region

16. Crosstabulation of Closing Cumulative CQA Scores by Region 104

17. Crosstabulation of Closing Cumulative CQA Scores by 105 Geographic Region

18. Results of Chi-Square Testing: Case Characteristics by 107 Cumulative CQA Rating at Case Closure

19. Results of Chi-Square Testing: Case Characteristics by 110 Reduction in Cumulative CQA Rating, Opening to Closing

20. Results of Chi-Square Testing: Case Characteristics by 110 Reduction in Mudd Safety CQA Rating, Opening to Closing

21. Distribution of Cases with Prior Treatment Episode, Means of Months .... 122 that Cases Were Previously Open and Means of Months Between Case Closing and Reopening

22. Frequency of Referrals in Cases at Closure 123

23. Frequency of Referrals in Cases Since Closure 124

24. Distribution of Cases with Recidivism by Region 126

25. Results of Chi-Square Testing: Case Characteristics by Repeat 129 Substantiated Maltreatment

26. Results of Chi-Square Testing: Case Characteristics by Reports 132 of Maltreatment, Substantiated and Unsubstantiated

27. Case Manager's Area of Study and Highest Educational Degree. 141

28. Supervisor's Area of Study and Highest Educational Degree 142

29. Comparison of Years of Service and Worker Position 143

30. Comparison of Overall Means of Case Managers/Supervisors and 144 Closing Cumulative CQA Scores 


\section{LIST OF FIGURES}

FIGURE

PAGE

1. Service regions of the Cabinet for Families and Children. ........................81

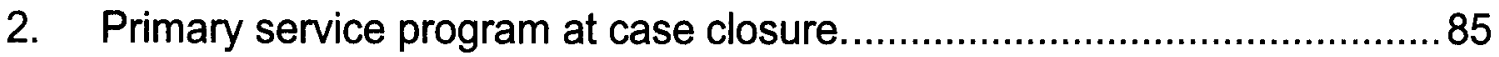

3. Flow chart of referral and service delivery process with independent........87 variables that are examined for relationship to overarching research question.

4. Comparison of Huebner's opening and closing Safety Risk Factor 96 scores.

5. Comparison of Mudd's opening and closing Safety Risk Factor scores .....96

6. Length of time from case closure to new referrals. ............................. 127

7. Number of children involved in reports of maltreatment since closure ...... 127 by case. 


\section{CHAPTER I}

\section{PROBLEM STATEMENT}

In this age of multiplicity and change, public social service agencies are challenged to demonstrate the effectiveness of their programs. The present age of accountability poses difficult challenges for child welfare agencies that are struggling to provide services within policy guidelines in a climate that emphasizes outcomes, efficiency, and economics. Although the measurement of the service outcome is not the only domain to which the social welfare administrator must attend, "there can be no defensible social work based definition of effectiveness oriented administrative practice without it" (Hudson, 1988, p. 59). Casework effectiveness is not a new issue. Was Flexner at the

Conference on Charities and Corrections in 1915 not questioning the effectiveness of social work when he called for the profession to demonstrate professionalism through the use of scientific methodology (Flexner, 1915)? Then in 1973, Fischer startled and challenged the social work profession with his seminal article, Is casework effective? (Fischer, 1973a)

Researchers, challenged by Fischer to demonstrate the effectiveness of child welfare programs, found little empirical data prior to 1974 (Cohn \& Daro, 1987; Magura \& Moses, 1986). This lack of documentation on child welfare services was addressed in 1974 with the passage of The Child Abuse and 
Prevention Act, which mandated that every state develop a system for managing child protective services, including mandatory reporting, investigation, and treatment. In 1976, the U.S. Attorney General issued a report that indicated (a) there was no valid system in place for determining the effectiveness of child welfare programs, and (b) effectiveness studies should include measures of the well being of the targeted population (Magura \& Moses, 1986). Defining child well being, however, was not without its difficulties. Child welfare agencies that attempted to develop valid and reliable measures to evaluate progress were confronted with a lack of consensus on desired objectives and difficulties in precise measurement of child well being (Magura \& Moses, 1980; Nasuti, 1998; Seaberg, 1988). While states struggled with developing systems for managing child protective services, the number of children being abused was rising at an alarming rate. From 1980 to 1986 , the incidence of reported child abuse and neglect increased by $66 \%$ (U.S. Department of Health and Human Services, 1993). Nationwide, more than 1.5 million children (25.2 children per 1,000) were reportedly maltreated each year. In 1988, the Child Abuse and Prevention Act of 1974 was amended to appoint a U.S. advisory board to assess progress in prevention and treatment of children. The board's report, submitted in 1990, stated that although the federal government had spent billions of dollars, child abuse was rising. The board suggested that child abuse should be considered a national emergency (U.S. Department of Health and Human Services, 1993). By the mid 1990s the need for additional reform was reflected in the rising number of 
children in out of home care, the length of time children were staying in care, and the lack of measurable child welfare outcomes.

Thus, the political and economic stressors of the early 1990s increased pressure for results oriented social programs, often in less time and with fewer resources (English, 1998; Freeman, 1995). Child protective agencies, overwhelmed by the number of children needing protection, treatment, and out of home care placements, were confronted with federal and state budgetary reductions (Dattalo, 1995; English, 1998; McCurdy, 1995; Videka-Sherman \& Viggiani, 1996; Wulezyn \& George, 1992). Federal funding for child welfare expenditures in Kentucky decreased 17.4\% from 1996 to 1998, with state funding decreasing $27 \%$ during the same time frame (Child Welfare League of America National Data Analysis System, 2003). As the demand for service increased in the 1990s and monetary support for community-based services decreased, social work professionals acknowledged the urgency of building knowledge about casework effectiveness (Alperin, 1993; Carter, 1988; Ell, 1996; Videka-Sherman \& Viggiani, 1996; Wells, 1994). This urgency was heightened with the passage of the Adoption and Safe Families Act of 1997, which mandated outcomes of safety, permanency, and well being. This dissertation focuses on safety by examining assessment and recurrence of maltreatment.

In 2000 an estimated 3 million referrals concerning the welfare of 5 million children were reported to protective service agencies in the United States as alleged victims of child maltreatment. Approximately 879,000 were found to be victims of maltreatment. In 2000, 12 out of every 1,000 children were 
substantiated as victims of abuse. An average of 2,400 children were found to be victims of abuse each day. Victimization rates declined as age increased. The youngest and most vulnerable children—children under 3-had the highest victimization rate. The National Child Abuse and Neglect Data System (NCANDS) reported that an estimated 1,300 children known to CPS died of abuse and neglect in 2001. Forty-one percent of these children were less than 1 year of age, while children under the age of 6 accounted for $85 \%$ of the fatalities (Goldman \& Salus, 2001; U. S. Department of Health and Human Services, Administration on Children, Youth and Families, 2003). Child abuse is indeed a national emergency.

Presently, the protection of children by caseworkers handling overwhelming caseloads emphasizes that efficiency and effectiveness of intervention are the foremost questions to be answered by Child Protective Service (CPS) research (Wells, 1994). Outcome research, utilizing follow-up studies, is critical to determining the effectiveness of CPS services. The examination of effectiveness in child protection is however, complicated by a multitude of intervening variables including (a) child protective services are most generally provided under the auspices of public welfare agencies with a shifting political foundation of programs, administrators, and funding, (b) the protective service client is generally involuntary, (c) decision-making is highly subjective and open to interpretation, (d) the types of services offered by protective service workers are many and varied, and (e) families are generally involved with multiple agencies simultaneously (Wells, 1994). 
Research findings on the effectiveness of community-based programs must move beyond numbers and case status data. Reid (1988) and Videka-Sherman and Viggiani (1996) challenged researchers to move beyond looking at largescale outcomes, which have been disappointing for so many child intervention programs and begin to study program variation. They stressed that future research should focus on explaining program variation and variables-client, practitioner, and administrative-linked with success. Child welfare researchers must be cognizant that failure to increase empirical research on social work interventions relinquishes to those outside the social work profession "the tasks of defining the important practice questions, selecting the appropriate research methodologies, interpreting the data and developing the implications for practice" (Kirk, 1991, p. 4).

\section{Purpose of the Study}

As workers and agencies struggle with the measurement of effectiveness, evaluating the likelihood of maltreatment becomes a key issue. The purpose of this dissertation is to add to the body of knowledge on measurable outcomes of effectiveness for child protective services by determining whether there is a relationship between child protective services provided by the Kentucky Cabinet for Families and Children (hereafter referred to as the Cabinet) and risk of maltreatment. The safety of children is the primary focus of child welfare and protective service workers, wanting to know if their work is effective, need valid and reliable measurement instruments for assessing risk. Therefore, the effectiveness of Kentucky's Continuous Quality Assessment Tool (CQA) 
(Appendix A) in assessing level of risk for child protection cases will be

examined. Level of risk, as measured by the CQA, will be compared to recurrent maltreatment to determine if a significant relationship exists between the two variables.

\section{Child Welfare Outcomes and Overarching Research Question}

Child welfare outcomes can be placed in three main domains: case status, client status, and client satisfaction (Magura \& Moses, 1980, 1986). Each of these domains contributes uniquely to the understanding of effectiveness of child welfare programs. Case status data includes such variables as (a) length of time a case is open, (b) findings of investigations, (c) whether a child is in out of home care, (d) timeliness of reviews, and (f) worker demographics. Client status data focuses on changes in child/parent/family behavior and well being. This dissertation will analyze case status and client status variables to answer the research question, What is the relationship between child protection services provided by the Kentucky Department of Protection and

Permanency and risk of maltreatment? Thus, this study supports the Cabinet's goal of developing a service delivery system based on proven needs, measurable outcomes, and fact-based policy development.

\section{Continuous Quality Assessment}

The Continuous Quality Assessment (CQA) is designed to guide workers in the collection, organization and analysis of information to better determine the safety, risk, and needs of families and children (Kentucky Cabinet for Families and Children, 2003). The CQA, which is based on the Safety and Assessment 
and Family Evaluation (SAFE) Model, was developed by a team of Cabinet staff and a group of consultants from the ACTION for Child Protection Institute (Holder, Costello, Lund, \& Holder, 2000). The SAFE model, which is described as a comprehensive safety assessment and planning approach for the family which focuses on threats to child safety, was designed and piloted in 1987. ACTION created and tested the first successful child safety intervention model in child welfare services in 1986 and since that time has assisted in implementing child safety intervention models throughout the nation. ACTION provides expert consultation, technical assistance, training and expert testimony to support states' efforts to establish effective child safety intervention decision-making and practices (Action for Child Protection Institute, 2003, paragraph 1). ACTION jointly operates The National Resource Center on Child Maltreatment (NRCCM) with the Child Welfare Institute in Duluth, Georgia.

CQA data are included in the Statewide TWIST database (since 1999), which also includes case based data. Therefore, changes in CQA ratings of risk can be related to strategies used for case management, family and child characteristics, and outcomes (Huebner, 2002). The worker assigns a risk rating of 0 to 4 in each of seven risk domains. A risk classification is generated based on the total risk score $(\mathrm{a})$ high risk $=20-28$ points, $(\mathrm{b})$ significant risk $=14-19.9$ points, $(\mathrm{c})$ moderate risk $=7-13.9$ points, and $(\mathrm{d})$ low risk $=0-6.9$ points (Kentucky Cabinet for Families and Children, 2003). Huebner (2002), conducting psychometric analysis of the scales using CQAs completed between December 1999 and March $2002(n=479)$, identified two factors being measured by the 
CQA-safety risk and child well being. The first factor of safety risk includes scores on maltreatment, sequence of events, and adult behavior risk domains. The second factor of child well being includes scores on family developmental tasks, choice of discipline, child development, and family support risk domains. A reliability analysis of the CQA found that the overall alpha coefficient of internal consistency was 0.79 . However, when the summary factors of safety risk and child well being were considered, the safety risk factor was adequately reliable with an alpha coefficient of .86. The well-being factor was found to be less reliable with an alpha coefficient of .53 . Huebner recommended that future analysis of the CQA include summary scores for the two factors.

\section{Supporting Standards of Accreditation and Cabinet Outcomes}

Kentucky, the first state in the nation to voluntarily seek accreditation for their protection and permanency programs, successfully achieved National accreditation in October 2002. To maintain accreditation, Kentucky must demonstrate that continuous quality improvement is an evolving process in service delivery. Therefore, this dissertation is designed to meet identified standards for the Council on Accreditation (Appendix B).

This dissertation is also designed to provide an evaluative measure of the Cabinet's outcome for quality service delivery. The Cabinet's outcomes are (a) safety for children and vulnerable adults, (b) family self-sufficiency (rather than dependency on government programs), (c) permanency for children and vulnerable adults, (d) child development and well being, and (e) quality service delivery, professional development, and community partnerships. These 
outcomes are driven by four goals: (a) to demand excellence from our human service delivery systems focusing on those we serve in the Commonwealth, (b) to promote an accountable, responsive, and integrated human services community, (c) to build, promote and advocate commitment for the Cabinet's human services mission, and (d) to maximize our financial, technological, and human resources to efficiently and effectively deliver services. As a measure of accountability, the Cabinet supports this examination of casework effectiveness.

\section{Child Welfare Services Defined}

Defining maltreatment is a significant methodological issue in conducting research on maltreated children (English, 1998; Gough, 1996; Kinard, 1994; Nelson, Saunders, \& Landsman, 1993; Winefield \& Barlow, 1995). Magura and Moses (1986) in their studies on outcome measures in child welfare adopted the definitions respectively of Kadushin (1978) and Reid (1979) for child welfare and child welfare services. Accepting these definitions, the field of child welfare is defined as "the broad range of activities designed to benefit children, promote their well-being and strengthen or assure provision meeting their physical, social, emotional, educational, and moral needs" (Kadushin, 1978, p. 4). Child welfare services are defined as those social services designed to "ensure that children will have the care, protection, and treatment they need when their parents, for any of a variety of reasons, are not able to provide these essentials" (Reid, 1979, p. 15).

Kinard (1994) pointed out that, although researchers prefer to deal with variables that can be easily and neatly quantified, maltreatment rarely exists in 
the pure forms desirable for research. Kinard encouraged researchers to adopt definitions of maltreatment that conform to statutory reportable conditions. In 1974, the Child Abuse Prevention Act (CAPTA), Public Law 93-247, was passed by the U.S. Congress to provide a national definition of child maltreatment and to define actions that states should take to protect children. The law defines child maltreatment as "the physical and mental injury, sexual abuse, neglected treatment or maltreatment of a child under age 18 by a person who is responsible for the child's welfare under circumstances which indicate the child's health and welfare is harmed and threatened" (Child Abuse Prevention and Treatment Act, Public Law 93-247, 1975, p. 5). This definition specifies that only parents or caregivers can be identified as perpetrators of child abuse or neglect. Maltreatment of children by other individuals is considered assault. According to Public Law 93-247, the four types of maltreatment identified in the definition include physical abuse, sexual abuse, neglect, and emotional injury. Physical abuse is defined as an act of commission by the caregiver that results or is likely to result in physical harm, including death of a child. Neglect is defined as an act of omission by a parent or caregiver that involves (a) refusal or delay in providing health care, (b) failure to provide basic needs such as food, clothing, or shelter, affection, and attention, and (c) inadequate supervision or abandonment. Emotional abuse is defined as an act of commission or omission that includes rejecting, isolating, terrorizing, ignoring, or corrupting a child. An important component of emotional or psychological abuse is that it must be sustained and repetitive. Sexual abuse is defined as an act of commission, including intrusion 
or penetration, molestation with genital contact, or other forms of sexual acts in which children are used to provide sexual gratification for perpetrators.

While CAPTA set minimal definitional standards for states receiving federal funds, the details of defining child maltreatment fell to the individual states. Kentucky's child protection program is mandated by statue, which means that there are laws that declare a child's right to be free from abuse and neglect. These laws, the Kentucky Unified Juvenile Code, are contained in Kentucky Revised Statues Chapters 600 to 645 (Appendix C). Inherent in the code are two basic principles: a child's fundamental right to be safe and to be nurtured, and a child's right to be raised by his/her own parents. Kentucky's definitions of child abuse are congruent with those established by the American Humane Society. Child abuse is defined by the American Humane Society as "non-accidental infliction or risk of infliction of physical, emotional, or mental harm to a child by a caretaker" (Filip, McDaniel, \& Schene, 1992, p. 323).

\section{Data Collection Overview}

A chart review of existing data was conducted on 3,235 closed CPS cases. Data were collected through a review of The Workers Information Sys $\underline{T}$ Tem (TWIST) reports and chart files using the Risk Assessment Quantitative Research Chart Review Form (Appendix D). TWIST is Kentucky's electronic case management system. TWIST, with over 75 screens and 600 data fields, collects information related to referrals, investigations, assessments, case planning, court, placements, payments, case management notes, placement and service providers. The chart review includes an examination of CQAs (Appendix 
A), service recordings, referrals, and TWIST reports. The chart review form is designed to gather information about the quality of service provided to the family, the change in the amount of risk assessed in the family, and the rate of recidivism following case closure. Analysis of these data will inform service providers and agency personnel about the effectiveness of services provided. Worker demographics for the identified case managers will be examined to further this understanding of effectiveness.

\section{Summary}

This dissertation begins to determine whether there is a relationship between child protective services provided by a State Department of Protection and Permanency and child safety. This researcher will examine the state's risk assessment tool and its effectiveness in assessing risk, as measured by the reoccurrence of abuse. Wells (1994) supported follow up studies as being critical to determining the effectiveness of child protective services. Therefore, recidivism will be assessed by examining reports of maltreatment in the identified cases for a one-year period following case closure. This dissertation will highlight successful outcomes with Solution-based casework in creating change with protective service families. Pecora, Fraser, Nelson, McCroskey, and Meezan (1995) challenge researchers and practitioners to remember that families being served are the ultimate beneficiaries of the research effort. Thus, this study on risk assessment as a measure of effectiveness will add to the body of knowledge on measurable outcomes for the Cabinet, which will enhance its ability to improve service delivery to the families and children of Kentucky. 


\section{CHAPTER II \\ LITERATURE REVIEW}

Legislation that defines child welfare and the role of state child welfare agencies has been a part of federal statues for nearly 30 years, yet workers and agencies continue to struggle with the measurement of casework effectiveness. Protective service workers want to know if their work is effective and need, therefore, valid and reliable measurement instruments for assessing risk. The complexity of measuring effectiveness and assessing risk in child protective services requires the researcher to have knowledge of the existing child welfare literature in a broad range of areas, dating to the beginning of the twentieth century. Relevant literature will focus on (a) the historical context of child protective services, (b) the breadth of effectiveness and outcome measurement research in child welfare, (c) risk assessment in child protective services, (d) Nationwide/Kentucky Child Abuse Statistics, and (e) Solution Focused Casework. The review of relevant literature will be concluded with a summary, followed by research questions.

\section{Historical Context of Child Abuse}

Child abuse is not a new problem and precedents for the ideas and values of defining child abuse and its treatment have been recorded throughout historical accounts of child welfare. Chambers (1993) pointed out that it is 
important to examine the contribution that history makes to the understanding of a social problem. Wells (1994) encouraged researchers to gain an understanding of the legal basis of child protective services and how that basis developed over the years, prior to planning for future services. She emphasized that all quests for knowledge should "be undertaken with a thorough knowledge of, and appreciation for, the structure within which child protective services are managed and delivered" (p. 431).

Although criminal cases involving child abuse were recorded as early as 1655 in Massachusetts, the abuse and neglect of children did not move from being largely a private matter to one of public concern until the late $19^{\text {th }}$ century (Filip, McDaniel, \& Schene, 1992; Watkins, 1990). By 1825, according to Folks (1902), there was a general recognition of the duty of public authorities to take action in cases of parental abuse and gross negligence, and by 1833 New York City had amended its charter to allow designated individuals to remove children who were neglected or suffering abuse at the hands of their parents. Folks (1902) pointed out, however, that duty to remove often resulted in the child's placement in an almshouse. Criminal prosecution was reserved for only the most severe situations, generally when the punishment was considered to be cruel and unmerciful or where there was permanent injury (Costin, 1991, 1992; Watkins, 1990).

Laws to protect children were not lacking but were not uniformly enforced during the $19^{\text {th }}$ century (Thomas, 1972). In 1874, the New York Society for the Prevention of Cruelty to Children (NYSPCC) was established following the much- 
publicized case of Mary Ellen Wilson. A concerned citizen seeking help for this child turned to the society for prevention of cruelty to animals for assistance based on the grounds that humans are a part of the animal kingdom ("Mary Wilson", 1874). Subsequently, the NYSPCC established the law enforcement approach to child rescue, which emphasized the removal of children from their homes and the prosecution of abusive parents (Anderson, 1989; Antler \& Antler, 1979; Costin, 1991, 1992; Filip, McDaniel, \& Schene, 1992; Watkins, 1990). The NYSPCC's annual report of 1894 reported the NYSPCC's involvement in the custody of over 230,000 children. Annual expenditures for the support of these children were $\$ 1.5$ million (Folks, 1902).

In other cities, dual-purpose humane societies were organized to protect children as well as animals. In 1885, the American Humane Association, which had been founded in 1878 as the national federation of animal rescue agencies, became, as well, the national federation of child rescue agencies (Anderson, 1989). The work of the child rescue agent consisted of receiving complaints of maltreatment, visiting the home, consulting with neighbors, deciding whether the complaint had merit, and taking appropriate action. The agent could chastise the caregivers for carelessness, give admonishment for more serious offenses, or in the most severe cases remove children temporarily or permanently (Anderson, 1989; Watkins, 1990). The work of the child rescue worker of 1878 bears a striking resemblance to the work of the child protection worker in the $21^{\text {st }}$ century. In fact, the American Humane Society's Helping in child protective services: A competency-based casework handbook continues in the $21^{\text {st }}$ century as the 
reference handbook for protection workers across the nation, including those in Kentucky.

In the latter part of the $19^{\text {th }}$ century, child rescue was considered a highly specialized, legalistic activity. Anti-cruelty societies were considered private-law enforcement agencies, not charities. From the beginning of the movement in 1874 , until the 1920s, the anti-cruelists, led by Elbridge Gerry, of the NYSPCC, relied primarily on coercive reform. In some cities, agents carried badges and were vested with limited police power. Investigations were swiftly completed, allowing for only one or two visits. Children found to be in the need of protection were routinely placed in institutions. Perceiving as an intrusion the new philosophy of "scientific social work," Gerry adamantly rejected Mary Richmond's principles of casework (Costin, 1992; Gerry, 1913). The Massachusetts Society for Prevention of Cruelty to Children (Massachusetts SPCC), established in 1878 by Boston philanthropists, led opposition to the Gerry tenets. By 1893, critics of anti-cruelty agents, such as Homer Folks, concerned with the lack of emphasis on placement, called for the anti-cruelty societies to integrate their services into the local child welfare system. Integration would have necessitated the agents answering to a higher authority than their local board of directors. In 1894, when the New York State Board of Charities undertook the responsibility of visiting, inspecting, and providing a measure of supervision to charitable institutions, Gerry refused to allow an inspection of the society's shelter for children. A lengthy court battle followed. Ultimately the New York Court of Appeals ruled in 
Gerry's favor-that the NYSPCC was a law enforcing, rather that a charitable institution, and therefore was not subject to the inspection (Costin, 1992).

At the 25th annual session of the National Conference of Charities and Correction in 1898 , Folks admonished those gathered to accept the responsibility they incurred by depriving a child of his natural caretakers and his relations to the community. Folks challenged workers to ensure that caretakers and surroundings, provided for the removed child, give the child a better start in life than the child otherwise would have had. Cushing emphasized that those who removed children from their families had an obligation to ensure that those children were placed in environments with improved living conditions. During this same conference one of the earliest efforts to develop typologies on clients presenting problems, Classification of Paupers, was presented (Lincoln, 1898). Lincoln (1898), concerned about the living conditions of vulnerable adults, called for the separation of almshouse inmates by conduct and character. In the ensuing years, Folks advocated for research to explore what was becoming of children when they left care (Folks, 1899, 1902). One hundred years later, the Adoption and Safe Families Act of 1997 raises these same issues as it promotes safety, permanency, and well being for children.

Grafton Cushing first raised the idea that child protective services should emphasize casework, as well as child rescue, at the December 1906 annual meeting of the Massachusetts SPCC. Cushing applauded agents who had loyally served the society, but he insisted that the time had come for the society to move toward prevention work by looking at the cause of the conditions that led 
to removing children (Anderson, 1989). A hundred years later as we continue to struggle with this concept, Christensen, Todahl, and Barrett (1998) reminded workers that "the investigative responsibility of protective service agencies often predispose assessment to focus primarily on whether or not the neglect, abuse, or out of control behavior occurred, rather than the more inclusive question of how it occurred" (p. 3).

The program that combined social casework and correction of dangerous community conditions with interventions on behalf of children in moral or physical jeopardy became known as child protection. In 1915, at the National Conference of Charities and Correction, Carl Carstens emphasized that child protection should be viewed as a public issue, not a private matter. Carstens held that child protection was essentially a public duty and advocated for every state to have an official body to license and oversee public and private child welfare agencies. Immediately following this meeting, Carstens, who had challenged child welfare agencies to work cooperatively, led a national effort to organize child welfare agencies and in 1921 the Child Welfare League of America was formed (Anderson, 1989; Carstens, 1915; Costin, 1992; DePanfilis \& Salus, 1992; Filip, McDaniel, \& Schene, 1992; Watkins, 1990).

The acceptance of child protection as a child welfare service and form of casework did not occur without controversy. According to Anderson (1989), many agreed with Mary Richmond that social casework constituted the core of social work, yet fewer agreed that the protection of children was a specialty that required casework skills. In the 1930s factors which accelerated the 
development of child protection as a form of social casework and had a significant impact on the development of child welfare services included (a) the addition of neglect to the definition of abuse in 1933 as needs outran services during the Depression, (b) the passage of the 1935 Social Security Act which ultimately led to the funding of many of the current programs within child welfare, including foster care and independent living, (c) the Child Welfare League of America adopted its first standards for child protection in 1936, (d) the passage of The Work Act in 1938 which raised issues of child labor abuse, (e) the growing discipline of social group work undercut social detection in defense of a child's morals as a means of dealing with delinquency, and (f) social workers began to discuss the social application of authority (Anderson, 1989; Costin, 1992; DePanfilis \& Salus, 1992; Filip, McDaniel, \& Schene, 1992; Watkins, 1990).

By 1940 , social workers were using the term "protective service" to mean service to neglected or abused children. It was also during the 1940 s that theorists began to call for social workers to be professionally educated in the general principles of social casework. In May 1945, the Child Welfare League of America held its second national conference on child protective services. Gane, a functionalist and executive director of the Children's Aid Society for the Prevention of Cruelty to Children of Buffalo and other casework theorists from competing schools began to write about the use of authority in protective service work (Gane, 1947). Tension between the diagnostic school (which stressed caseworkers' ability to diagnose clients' unconscious conflicts in order to mobilize their conscious strengths) and the functional school (which stressed 
caseworkers' ability to impart their agencies' function in order to engage the client's will) became heated. Anderson, reflecting on this controversy, pointed out, however, that if there was one field of practice where accommodation of multiple theories seemed possible, it was child protection. According to Anderson (1989) post war theorists elaborated on principles by Carstens to justify the protection of children and on Lee's concept of authority to justify child protective casework.

According to Gordon (1946), child protective workers needed to grasp and profess the function — the constituted authority—of their agency. Gordon listed four "distinctive characteristics" of child protective service:

1. Service must be initiated by the agency; since the application or the referral is a complaint of neglect or abuse, the individual who needs the help is not asking for it.

2. The individual to whom help is being offered is not free to decide that he does not want the services of the agency

3. The agency cannot withdraw the service only because the parent has refused or is unable to take help.

4. Should the parent or guardian be unable to improve the condition while the agency sees it as one that endangers the children, the agency must bring the matter to the attention of the court with recommendations for proper care. (Gordon, 1946, pp. 1-6)

Review of the literature suggests that Gordon's were the preeminent guidelines for child protective agencies in postwar America. Anderson (1989) 
pointed out, however, that for caseworkers to effectively utilize the constituted authority of their agencies they must (a) place their agencies within its social welfare system, (b) master their agencies' policies and be able to enlist other community resources, (c) make swift and sure determinations, (d) know family law and be familiar with court proceedings, (e) distinguish the possible from what is impossible and deal with the individual and community on that basis, and (f) proceed from investigation through assessment, with respect for each individual involved and the best interests of the child. Thus, as summarized by Anderson (1989), "knowledge, commitment, and skill were what it took to make a child protective caseworker truly authoritative" (p. 239).

In the early 1950s child protection won professional recognition as a child welfare service and form of social casework. In 1951, the American Humane Association issued the first set of national child protection standards, which mandated that child protective workers have professional degrees. During the post-war climate of the 1950s, with the return of husbands and fathers to their families and with the high rates of new marriages and childbirth, the sanctity of the family was celebrated. "The idea of involuntary intervention by community agents into family life on charges of child abuse was unthinkable, almost abhorrent, in the climate of conservatism throughout the 1950s" (Costin, 1992, p. 193). By 1958, however, the American Public Welfare Association asserted that preventive and protective service to children was a responsibility of the public welfare agency (Anderson, 1989). 
Current child protective service programs have evolved as a result of four major legislative movements (Filip, McDaniel, \& Schene, 1992; Pecora, Fraser, Nelson, McCroskey, \& Meezan, 1995; Wells, 1994). The first movement occurred in the early 1960s with the recognition of the battered child syndrome, which led to reporting laws being passed in every state. Federal, state, and local authorities, responding to criticism of the child welfare system, instituted a number of policy and program innovations. Public policy directed efforts toward providing social services to families to enable parents to parent their children in a safe effective manner.

The second legislative movement followed the passage of The Child Abuse Prevention and Treatment Act in 1974 (CAPTA)(Public Law 93-247). CAPTA linked state compliance with federal regulations to federal funding for child abuse programs and thereby set national standards for child protection investigations. Child protective services were described as short term, intensive services designed to protect children and preserve families (Child Abuse and Treatment Act, 1975).

The third legislative movement began with the passage of The Adoption Assistance and Child Welfare Act of 1980 (Public Law 96-272). This was the first legislation that tied federal foster care funding to family preservation and permanency planning. Public Law 96-272 mandated that caseworkers and courts demonstrate that "reasonable efforts" were made to prevent the removal of children, and that "reasonable efforts" continued to be made to return children home within established timeframes (Adoption Assistance and Child Welfare Act, 
1981, Sec. 101, p. 1567). Wells (1994) pointed out that this mandate had "enormous psychological impact on the field" (p. 432).

By the mid 1990s the need for additional reform was reflected in the rising number of children in out-of-home care. Thus the fourth legislative movement began with the passage of The Adoption and Safe Families Act of 1997 (ASFA)(PL 105-89). ASFA signaled a drastic philosophical shift in policy and practice, recognized the importance of evaluative measures, and mandated the Secretary of the Department of Health and Human Services, ... in consultation with Governors, State legislators, State and local public officials responsible for administering child welfare programs, and child welfare advocates. . . to develop a set of outcome measures that can be used to assess the performance of States in operating child welfare programs. .. In addition the law required that ... to the maximum extent possible, the outcome measures should be developed from data available from the Adoption and Foster Care Analysis and Reporting System (AFCARS). Section 203 of ASFA also directs the Secretary to prepare and submit to congress a report ... on each outcome on May 1, 1999 and annually thereafter. (Adoption and Safe Families Act, 1998, Sec. 202, pp. 2126-2127)

Federal Outcome Measures include safety, permanency, and child well being. ASFA gave to the states, for the first time, specific tools to expedite permanency and ensure safety for children. At the same time, the act holds the states 
accountable, with specific time frames for achieving permanency, to stated core outcomes and systemic factors.

In summary, the issue of child abuse did not become a public issue until the late $19^{\text {th }}$ century. The philosophy in child protection has included both, "rescue the child," as well as "rescue the family." History indicates that public, as well as private agencies have provided child protective services. Laws at the federal, state and local levels have been passed. Yet, in 1976, following the passage of the Child Abuse and Prevention Act of 1974, the U.S. Attorney General stated that little empirical support existed that demonstrated the effectiveness of child welfare programs. He recommended that studies on effectiveness should address the well being of the targeted client population. Since 1976, a multitude of service approaches have been tried, billions of dollars have been spent, sanctions have been applied, monetary rewards have been presented and laws have been enacted in an attempt to protect our children. Yet as we move into the $21^{\text {st }}$ century we continue to struggle with defining and analyzing outcomes that assess the permanency, safety and well being of children.

\section{Effectiveness and Outcome Measurement in Child Welfare}

The effectiveness of interventions utilized with abusive and neglectful families has been questioned; however, data available on child maltreatment interventions does support the usefulness of specific interventions with maltreating parents (Beck \& Jones, 1973; Cohn \& Daro, 1987; Cohn \& DeGraaf, 1982; Howing, Wodarski, Gaudin, \& Kurtz, 1989; Magura, 1982; Magura \& Moses, 1980; Magura \& Moses, 1984; Shireman, Grossnickle, Hinsey, \& White, 
1990; Wood, 1978). Giovanni (1982) writing on research efforts in child welfare, challenged the research community to consider, "regardless of how social workers count or measure their failures or successes, their concern cannot stop with finding out simply what works, they also know for whom it works" (p. 30). To further our understanding of what works, the literature on the effectiveness and outcome measurement in child welfare was examined. Individual studies dating to the late 1960s, as well as meta-analyses of published literature dating to the 1930s are included in this review.

Both Briar and Fischer found that casework and group work were not effective (Briar, 1968, 1973; Fischer, 1973a, \& 1973b), although Briar did qualify his finding by stating that ineffective casework was indicative of the caseworker performing psychosocial therapy. Briar (1968) examined two criticisms of casework: (a) the casework method excluded many of the persons most in need of attention from caseworkers, and (b) the casework method was not effective even when applied to persons disposed to use it. Briar also emphasized that casework of the first two decades of the $20^{\text {th }}$ century was vastly different from casework being performed in the 30 years prior to 1968 . He characterized the earlier caseworker as an individual of many functions, social broker, advocate, educator, and social reformer. The caseworker of the more recent past however was described as a "therapist." Briar cautioned caseworkers to modify their belief that all clients were ill. Briar (1968) concluded that, "we (social workers) must develop an expanded conception of casework, one that embraces a variety of functions" (p. 8). Specht (1968) and Miller (1968) concurred with Briar's 
expanded vision of casework and all were in agreement that the client should be returned to the position of deciding what "he does and does not want" from the caseworker (Briar, 1968, p. 8). All were also in agreement that the purpose of their criticism was to contribute to social casework advancement, not to suggest its elimination. Briar concluded by pointing out that the advance of casework depended on research, for only research findings would enable social workers to discover the particular effects of casework methods (Briar, 1968).

Fischer (1973a) examined studies reporting on casework effectiveness dating back to the 1930 s. Although he initially identified over 70 studies, only 11 of the studies met his criteria for inclusion in his study: (a) casework services were provided by a professional MSW caseworker, and (b) the study utilized a control group. Fischer concluded that there was a lack of effectiveness and in approximately $50 \%$ of the studies clients receiving casework services tended to deteriorate. Fischer's findings created a casework furor. A number of researchers, critical of this sweeping generalization, suggested that this conclusion could not be inferred from the research studies themselves (Alexander \& Siman, 1973; Gyarfas \& Nee, 1973; Hudson, 1974). Concurring and counterpoint views were subsequently printed in multiple social work journals. Fischer's findings on casework effectiveness, thus began a debate on casework effectiveness, which to date remains unresolved.

Wood (1978), following Fischer, also studied the research evidence of prior studies to make a determination about casework effectiveness. Wood's literature review, which covered 1956 to 1973, found 53 studies on the effectiveness of 
social work direct practice. From this sample Wood found 22 studies which met her criteria which included (a) investigating the outcome of direct practice interventions, (b) having social work intervention as a major component, (c) having been conducted in the United States, and (d) being methodologically adequate. The study's major interest was in what these research projects had added to or subtracted from the theory that informs practice in a variety of problem areas. The studies were grouped according to whether their major focus was on service to a particular group of clients or to the outcome of a particular intervention.

Wood's (1978) first group included six studies of delinquency and supported Fischer's conclusion: casework and group work were not very effective (Berleman, Seaberg, \& Steinburn, 1972; Craig \& Furst, 1965; Miller, 1957; Webb \& Riley, 1970). Of significance to today's practice, however, was the finding that none of the studies began with the adolescents' perceptions of their own problems. According to Wood (1978) "the researchers began with their own theoretical and ideological orientations, which they applied to their clients like a magic formula" (p. 440). The professionals assumed they knew what the problems were; therefore, there was no partnership between client and professional. Middleman and Goldberg (1972) had commented on this power inequity when they stated, "the image of a social worker is a lady who knows better than you do what is best for you and your family and who has the power of the Establishment to enforce her better judgment-power to stop your welfare check, label you mentally ill, and take your child away" (p. 48) 
Wood's (1978) second group included four studies of children living in the ghetto and was concerned with preadolescent treatment issues. The majority of children were found to be doing well; however, supporting Fischer's earlier conclusion, there were no significant differences between the control and experimental groups (Craig \& Furst, 1965; Levitt, 1957). Again, however, important practice questions were left unanswered. The study did not look at what qualities in the families enhanced their children's abilities to succeed and although there was a difference in the Puerto Rican, White, and African American children, no exploration of this finding was conducted. No within group analysis was conducted and therefore, valuable information was lost (Wood, 1978).

Wood's (1978) third group included nine studies of recipients of public welfare. Results were inconclusive, as the findings were divided (Brown, 1975; Geismar \& Krisberg, 1966; Olson, 1970; and Wilkinson \& Ross, 1972). Seven of the studies dealt with assessing the impact of intensive casework by public agency workers and Wood concluded from these studies that researchers had accepted the assumption-poverty was necessarily the result of personal or family inadequacy. By assuming the problem was within the individual, researchers like therapists jeopardize their effectiveness with families. Of significance from these studies was Wood's assertion that the "definition and assessment of the client's problem situation must precede the intervention and that dysfunctional social system variables must be highlighted in both assessment and intervention" (Wood, 1978, p. 447). 
Wood's (1978) fourth group consisted of two studies on the aged. The findings of this study indicated that social work services individualized to a person or a family could make a particular impact in connecting people with services. Christensen, Todahl, and Barrett (1999), Dattalo (1995), and Middleman and Goldberg (1974) supported Wood's conclusion by emphasizing that solutions to the problems of children and families must be grounded in recognition of their individual characteristics and need.

Wood's (1978) final group consisted of five studies that compared the effects of different forms of interventions. Reid and Shyne's (1969) well-known study of clients experiencing marital or parent-child problems was a part of this group. This study examined the comparative effectiveness of short and long-term treatment. Reid and Shyne (1969) found short-term planned treatment to be superior to the more open-ended and diffuse model. Wood concluded her analysis of casework effectiveness by identifying six principles of quality casework: (a) accurate definition of the problem, (b) in-depth analysis of the problem—including identifying factors creating or maintaining it and factors that can help resolve it, (c) thorough assessment of the problem's workability and setting goals, (d) negotiation of a contract with client, (e) planning a strategy of intervention, and (f) ongoing evaluation of the intervention (Wood, 1978). The U.S. Attorney General's 1976 report on lack of valid measures for determining effectiveness of child welfare programs, issued in this climate where social workers were struggling to demonstrate effectiveness of their profession, brought heightened public awareness to outcome measurement in child welfare. Claburn, 
Magura, and Chizeck (1977) completed one of the earliest outcome studies in child welfare. They investigated the frequencies and correlates of case reopenings in child welfare and found that one-third of all closed cases were reopened during the review period. The study included all children accepted for supervision from January 1,1971 to July 31,1971 by the New Jersey Division of Youth and Family Studies. A sample of 612 cases was drawn from the identified population and followed from their date of acceptance to October 31, 1975. The age, ethnicity and extent of prior agency experience were found to be good predictors of case closing and subsequent reopening. Prior agency involvement was the strongest predictor, raising a number of questions whether (a) the agency encourages dependency, (b) insufficient services were provided, (c) cases were terminated in violation of good casework standards, and (d) some families simply had particularly difficulty problems. They concluded that case reopening is an accessible measure that agencies should consider in evaluative research.

By 1979, problems in demonstrating effectiveness and accountability in child welfare programs "threatened to erode public support for the maintenance and enhancement of essential services to 2 million children and their families" (Magura \& Moses, 1980, p. 595). As part of a federal initiative to improve evaluation and decision making in child welfare, the Child Welfare League of America (CWLA) received a grant in 1979 to identify existing measures suitable for evaluating outcomes in child welfare. The CWLA conducted a nationwide mail survey that included (a) the 50 state-level departments responsible for the 
administration of child welfare programs, (b) the 393 members and associate agencies of the CWLA in the United States and Canada, and (c) both private and public agencies (Magura \& Moses, 1980). Note that Magura was the director of the CWLA outcome measurement project and Moses was research associate for the project.

Surveys were returned by 32 of the state agencies and 164 of the CWLA members. According to Magura and Moses (1980) the results of this study provided a broader base for assessing outcome measurement techniques than had previously been available. Overall, $43 \%$ of the respondents reported routine use of a structured client outcome measure for at least one of their services. Of concern, considering the mandated public support for child welfare services was that public agencies were less likely to use structured outcome measures than private agencies. The use of client self-reports, obtained through interviews, questionnaires, or self-administered tests, to help assess outcomes was fairly common among private agencies employing structured measures; however, none of the state-level agencies responding used a client self-report for routine evaluation of any service. When respondents were asked whether they would find useful a procedure to assess client progress based on structured client interviews or surveys, $69 \%$ of the agencies responded affirmatively. The survey in 1979 clearly indicated a need for increased efforts to develop new structured outcome measures for child welfare.

Magura and Moses (1980) found that follow-up data, obtained 6 months or longer after case closure, were gathered in only $20 \%$ of child welfare cases. 
Magura and Moses (1980) consequently pointed out that the concept of case outcome in child welfare was not well defined and few agencies in 1979 questioned "the necessity or desirability of improving outcome measurement techniques in child welfare" (p. 599). Arguing for measurements that measured actual changes in personal or situational characteristics of clients, Magura and Moses (1980) emphasized, "outcome measurements should help inform agency decision making, not be identical with it" (p. 601). They also found that approaches to measuring client outcomes generally failed to provide information anchored to legal or community definitions of minimally acceptable standards.

Magura (1982) reported that clients receiving child protective services were able to offer valuable insights into service activities and case outcomes. This finding was based on a study involving 34 families (22 families receiving intensive services and 12 control families receiving regular agency services) whose child(ren) were considered by a protective service agency to be at risk for out of home placement. The 34 families represented $43 \%$ of the at risk population who were eligible for the study. Using factors obtained from intake data, no significant difference was found between families choosing to participate and families not participating, primarily due to their unwillingness. As part of the project evaluation, in-person parent interviews were conducted with both groups after one year of service, or at case closing if earlier.

Magura (1982) measured clients' perception of change by posing the following question to families, "How would you say things are now for your family as compared with when you were referred to the agency?" (p. 523). Responses 
were as follows, much better $(47 \%)$, somewhat better $(23 \%)$, the same $(15 \%)$, somewhat worse $(3 \%)$, much worse $(3 \%)$, or better in some ways, but worse in other ways (9\%). These findings were consistent with Beck and Jones (1973), Maluccio (1979), Rubenstein and Bloch (1978), and Shapiro (1979). Beck and Jones (1973) had asked a question similar to Magura of family service agency clients on a mailed questionnaire to which $32 \%$ of the respondents rated their situations as much better and another $38 \%$ rated them as somewhat better.

Overall, $70 \%$ of the clients responding rated their situation as better.

Magura (1982) cautioned that the improvements perceived by clients might not be significant from an observer's perspective. Beck and Jones (1973) stated that clients rated their outcomes more positively than did the clients' counselors. Thus, Magura (1982) requested that parents report concrete changes. The most frequently reported change was an "improvement in self-confidence accompanied by an increased capacity to cope with their feelings and life stresses" (p. 523). Other changes reported were improved living conditions and children's behaviors. These findings for protective service clients parallel those of Beck and Jones (1973) for family services, who found the most frequently reported change to be changes in the client's own feelings and perceptions. Magura (1982) stressed that this is a contradiction to the concept that protective service clients tend to identify the source of their problems outside of themselves. Thus, clients who reported improvement in their mental and emotional well being had some awareness that their feelings and perceptions had a potentially damaging impact on their child rearing abilities. When clients were asked to 
identify services that did or did not help, they responded most often that the social work counseling provided by their caseworkers made the greatest contribution to the improvements perceived (Magura, 1982). Magura emphasized that he found little evidence that clients were unresponsive to guidance from their caseworkers. Empathy, genuineness, unconditional positive regard, and accessibility were the reasons given by clients for their satisfaction with their caseworkers.

Cohn and DeGraaf (1982) contributed to the body of knowledge on outcome measurement in child welfare by identifying the essential elements of quality case management in the child abuse field. Using audit techniques from the medical field these researchers examined the relationship between case management and treatment outcomes ( $n=354$ child abuse cases). This study was a part of a multi-year evaluation of a national demonstration program in child abuse and neglect, the overall purpose of which was to provide direction to federal and local governments on how to develop effective child abuse and neglect treatment programs. Cohn and DeGraaf (1982) found only two factors associated with case management to have strong relationships with client outcome: length of time in treatment and caseload size. They suggested that treatment outcome may be more related to the (a) content of worker/client interaction, (b) type of treatment service provided, and (c) client's individual situation. Workers with smaller caseloads, more years of experience in child abuse and neglect, and more formal education appeared to be those managing cases more appropriately (Cohn \& DeGraff, 1982). In cases with high quality 
case management ratings $79 \%$ of the case managers were handling fewer than 20 cases, $67 \%$ of the case managers had three or more years of experience and $80 \%$ of the case managers had increased their formal education.

Blythe (1983) analyzed the methods and findings of 16 studies of child abuse treatment programs (1975-1983) and reported inadequate reporting documentation in all 16 studies. According to Blythe, the 16 studies selected were the bulk of existing literature on outcomes of intervention with abusing parents. Blythe examined only studies that specified the independent variable, measured outcomes, and defined populations receiving treatment. Blythe reported that the studies (a) rarely documented the abuse or neglect, (b) included no severe or life threatening abuse, although they may have been present, (c) were limited in demographic information, often including only the ages and sex of abusing parents and abused children, and (d) included no random sampling techniques, the sampling plan being convenience in every case. Blythe encouraged future researchers to provide more in-depth descriptive information, particularly with single-case studies, in order that other workers might make more informed decisions about using particular treatment approaches with their clientele.

Blythe (1983) pointed out that since the cases in the studies were not randomly drawn and severe cases of abuse were not included, the degree to which the families studied represented child abusing families in general was questionable. Blythe found the research designs in the 16 studies to be relatively simple, with only 4 of the studies having a measure of whether child abuse 
persisted after the parents received treatment. Blythe (1983) concluded from her review that since the studies rarely used child abuse as the dependent variable, little could be said about whether the treatment package actually eliminated or reduced abuse. Recommendations for future research in child abuse treatment outcomes included (a) documentation of treatment, to include specification of treatment package components and standardization of their delivery, (b) presentation of client demographics, (c) presentation of client problems in specific, quantifiable terms, and (d) examination of the circumstances under which the treatment is delivered.

Magura and Moses (1984) tested a standardized interview for use with protective service clients (Parent Outcome Interview) and found parents to be candid in talking about parent/child issues. Child protective services seemed "moderately beneficial" across a wide range of content areas. Kadushin (1980) found that outcome information in existing studies had been obtained predominantly from case records and caseworkers, even though clients had successfully participated in the evaluation process in other human services. Magura and Moses (1984) suggested that this hesitancy to solicit feedback from protective service clients may be due to (a) a bias that protective service parents are less capable, articulate, and objective than other human services recipients, and (b) the difficulty of engaging these parents for research interviews.

Magura and Moses (1984) challenged workers/researchers to place greater reliance on client feedback for evaluative purposes, stating that $70 \%$ of their sample reported at least mild overall satisfaction with the services. They 
reported that while only $25 \%$ of their respondents disagreed with the facts of the initial referral, $60 \%$ had at least one criticism of the agency and when parents were asked, "what helped the most?" $25 \%$ of the clients alluded to positive traits or relationships with their caseworkers. This supports Cohn and DeGraff's (1982) suggestion that treatment outcome may be related to factors such as the content of the worker/client interaction. The most frequently mentioned source of dissatisfaction came from disagreement with workers' approaches to treatment (Magura and Moses, 1984).

Cohn and Daro (1987) reported that the U. S. Federal Government funded four major multi-year evaluations to determine the effectiveness of different approaches to the treatment of child abuse and neglect: (a) Berkeley Planning Associate's (BPA) evaluation of 11 programs in child abuse and neglect $(n=$ over 1,600 families), (b) BPA's evaluation of 20 demonstration and innovative treatment projects funded by the National Center on Child Abuse and Neglect (NCCAN) ( $n=488$ families), (c) White's evaluation of 29 service improvement grants funded by NCCAN ( $n=165$ families), and (d) BPA's evaluation of 19 clinical demonstration projects funded by NCCAN ( $n=1,000$ families). With data on 3,253 families involved in 89 treatment programs, spanning over a 13 year period (1974-1987), and costing over $\$ 4$ million dollars, disturbingly, at least onethird of parents maltreated their children while still involved in treatment and over one-half were judged likely to mistreat their children following termination. Cohn and Daro (1987) suggested that successful intervention with maltreating families requires a comprehensive package of services that address both the 
interpersonal and concrete needs of all family members. Christensen, Todahl, and Barrett (1999), the authors of Kentucky's Solution-based casework, support a comprehensive package of services that addresses individual, as well as family level objectives.

Rapp, Hardcastle, Rosenzweig, and Poertner (1983), while reviewing the literature in human service management, found that less than one-half of the articles contained any mention of outcome variables and in only $7 \%$ was the dependent variable related to client outcomes. Only $20 \%$ of the 136 articles reviewed presented a measurement of change on the dependent variable. Patti (1985) suggested that this might be a result of disciplines, other than social work, taking leadership roles in human service organizations. Patti emphasized that service effectiveness should be the "bottom line" or primary object of performance assessment in social welfare management. Patti pointed out that service organizations may have settled for units of service provided as outcomes due to previous inability to document what works.

Rapp and Poertner (1988) pointed out that social work (a) had not exerted its administrative advantage over other management disciplines, and (b) must focus on client outcomes. They proposed a taxonomy of five outcome measures that are applicable across human services: (a) affective changes, (b) learning, (c) behavioral changes, (d) status maintenance or change, and (e) environmental changes. Rapp and Poertner (1988) declared, "failure to monitor client outcomes substantially and then use those data to improve operations is tantamount to managerial irresponsibility, incompetence, and unethical conduct" (p. 35). 
Carter (1988), after 10 years of studying social service programs, concluded that few programs were asking the question: Did we make a difference? Programs found to be examining outcomes included Michigan, Minnesota, and Texas, which had implemented outcome gathering information systems that were used for planning, evaluation, and cost/benefit analyses by 1981. Carter (1988) suggested that because social programs were generally considered "intrinsically good," they had been protected from serious reviews of outcomes. Carter concluded, however, that "without adequate outcome measures, there is no basis to judge effectiveness" (p. 75).

Howing, Wodarski, Kurtz, and Gaudin (1989), studying the etiology and effects of child maltreatment, found that the extensive body of research was flawed methodologically, including (a) inadequate definitions, (b) lack of sound theoretical foundations, (c) cross-sectional design limitations, (d) sampling gaps, and (e) inadequate or missing control groups. They stressed that the failure of early studies to differentiate by type of abuse has resulted in inconclusive findings.

Kinard (1994), like Howing, Wodarski, Kurtz, and Gaudin (1989) found that the classification of multiple forms of maltreatment presented a methodological issue for researchers. Children may experience more than one form of maltreatment, of varying degrees of severity, and possibly at different points throughout their lives. Therefore, observed outcomes must be viewed as cumulative. While Howing, Wodarski, Kurtz, and Gaudin (1989) stressed that there is some benefit in focusing on subtypes (physical/sexual abuse and 
neglect), they cautioned that there is so much over-lap between the subgroups that isolation of the effect of any one type of abuse can be difficult and misleading. Howing, Wodarski, Kurtz, and Gaudin (1989) encouraged future child maltreatment researchers to use multiple measures and sources of data to examine the interrelationships between parents, children, and given situations, and to use a social interactional framework to search for factors that mediate between the presence of high-risk factors and the occurrence of maltreatment.

Shireman, Grossnickle, Hinsey, and White (1990) joined the chorus of those lamenting how difficult it is to develop valid outcome measurement. They examined the difficulty in deciding who should supply outcome data: clients, workers, or parents? To address this question, Shireman, Grossnickle, Hinsey, and White (1990), using outcome measures developed by Magura and Mosses (1986), conducted an outcome study of protective services in which they investigated the congruence between the agency's case file and parental reports. Shireman, Grossnickle, Hinsey, and White (1990) were interested in the parents' ability to accurately recall information about (a) incidents which happened up to 2 years in the past, (b) contacts that were made by different individuals from a variety of service agencies, (c) contacts made by agencies raising questions regarding care and safety of children, and (d) traumatic events that parents generally do not wish to recall. They reported high congruence between parental report and case record information. This congruence however, did not extend to the parental report on which services had the most significant impact on the outcome. The parents' perceptions of services received and the case record's 
narrative of services offered showed wide variation. Parents generally felt strongly about the services received, describing some in the most positive terms and some in the most negative terms. Shireman, Grossnickle, Hinsey, and White (1990) reported that $70 \%$ of the parents were providing a "fairly good quality of care" for their children, suggesting that services provided were successful in protecting children (p. 176). With $80 \%$ agreement, the study validated both parents and records as data sources for examining the effectiveness of protective services.

Kinard (1994) cautioned researchers to be alert to potential biases in their study samples, pointing out that many studies of child maltreatment draw their samples from hospitals or clinics. Kinard cautioned that samples drawn from these settings may include an over-representation of younger, more severely injured children and encouraged the use of public protective service agencies as the most representative population of abused children for study. Hampton and Newberger (1985) cautioned, that even when samples are drawn from public protective service agencies, reported cases are likely to over represent low socioeconomic or minority families because of bias in recognizing and reporting abuse. Kinard (1994) also stressed that access to public protective service populations is difficult to achieve and to increase access, research objectives must be proposed with questions that fit agency goals. For example, the Cabinet is developing a service delivery system based on proven needs, measurable outcomes, and fact-based policy development; and obtained national accreditation in October 2002. Therefore, the research objectives of this study 
have been written with attention to Council on Accreditation Standards and Cabinet outcomes (Appendix B).

According to Hudson (1988) the driving force behind the concept of service effectiveness is the simple notion of change. Yet Carter (1988), after 10 years of studying social service programs, concluded that few programs were asking whether they were making a difference. One-third of parents serviced by protective agencies will maltreat their children during treatment, with the percentage of maltreatment rising to one-half following case closure. Therefore, it is imperative that we examine the effectiveness of our protective programs.

\section{Risk Assessment in Child Protective Services}

With a million children a year being abused, evaluating the likelihood of maltreatment is a key decision in the child protective service process (DePanfilis, 1996; English, 1998; Fuller, Wells, \& Cotton, 2001; Haskett, Scott, \& Fann, 1995; Lyons, Doueck, Koster, Witzky, \& Kelly, 1999; McDonald \& Marks, 1991; Seaberg, 1988). Risk assessment-based decision-making, has been used successfully in the fields of juvenile and adult corrections, but is relatively new to child abuse prevention (Depanfilis, 1996; Haskett, Scott, \& Fann, 1995; Lyons, Doueck, Koster, Witzky, \& Kelly, 1999; McCurdy, 1995; McDonald \& Marks, 1991; Nasuti, 1998; USDHHS, April 1993; Wald \& Woolverton, 1990). The complexity of measuring effectiveness and outcomes in child protective services requires the researcher to have knowledge of risk and risk assessment in a broad range of areas. Relevant literature on risk will focus on (a) paradigm of risk society, (b) risk assessment decision making, (c) defining child well being, (d) 
life events and environmental factors, (e) risk assessment to improve clinical judgment, and (f) assessment tools.

\section{Paradigm of Risk Society}

Ferguson (1997) examined the nature of late-modern child protection by placing it in the context of the paradigm "risk society" (p. 221). Beck (1992), who coined the term "risk society," held that this does not mean that life has become more risky, but rather refers to the fact that as a result of major social changes, a concern with risk and its management has become central to everyday life. This is particularly evident in the field of child protection, where "high risk" criteria and risk assessment have become intricately interwoven in the casework practices of protection workers.

Ferguson (1997) used child death to illustrate changes in the viewing of risk in child protection. During the late $19^{\text {th }}$ century and early $20^{\text {th }}$ century the publicizing of child death was viewed as a sign that the system was working. Public awareness was being generated for an issue that had previously been considered a private matter. By the 1920s the promotion of child welfare had moved society to collectively believe that children should be protected in time to prevent serious harm or death. Therefore, by the 1930s, a child's death was viewed as agency failure, the information usually sequestered because disclosure threatened the public's perception that the system was protecting children. Since the 1970s, disclosures of professional failures have led to a heightened awareness of risk and a "new professional risk consciousness" in child protection (p. 221). At the core of risk society is an awareness of risk and 
this involves knowing that knowledge gaps exist in terms of risks, which cannot be converted into certainties (Giddens, 1994).

\section{Risk Assessment Decision-Making}

A child's well being is the primary issue in the decision of whether a child can safely remain in the home (Seaberg, 1988). Likewise, the child's well being can be a measure of program success or failure. Measurements of child well being should include risk factors that have been demonstrated to be associated with current or future well being (DePanfilis \& Zuravin, 2001; English, 1998; Fuller, Wells, \& Cotton, 2001; McCurdy 1995; Nasuti, 1998). DePanfilis and Salus (1992) pointed out that while there may be less consensus about specific causes, most will agree that child maltreatment occurs as a result of multiple forces that impact the family, interact, and reinforce each other, and eventually result in child abuse and neglect. Children are at risk of maltreatment, then, as a result of the pattern of interaction between themselves and their environments.

Most would also agree with DePanfilis (1996), that the primary purposes of child protective agencies offering services to children and families after reports of child abuse and neglect have been substantiated are to prevent the reoccurrence of abuse and address the effects of maltreatment. However, the staggering reality according to Cohn and Daro (1987) is that one-third of parents serviced by child protective agencies will maltreat their children during treatment, with the percentage of repeat maltreatment rising to one-half following the completion of service delivery. On the more positive side, however, over $40 \%$ of the parents will not reabuse. Although numerous studies have identified factors 
correlated with maltreatment, few have identified risk factors that predict abusive or neglectful behavior (DePanfilis \& Zuravin, 2001; Nasuti \& Pecorra, 1993; Pecora, 1989).

DePanfilis \& Zuravin (2001) contributed to the sparse literature about decisions made to open or close cases following substantiation of abuse or neglect. They found that the decision to open child protective cases $(n=1,167$ families) is not based on substantiation status alone. Only two variables significantly predicted case opening: (a) families with a previous substantiated report were $22 \%$ less likely to be opened for service than families without a previous substantiated report, and (b) cases substantiated for neglect were $20 \%$ less likely to be opened for service than physical abuse. The field at large tends to view families with neglect problems as less serious despite the fact that a history of neglect is recorded in child fatalities more often then that of physical abuse (Goldman, \& Salus, 2001; USDHHS, 2003). Depanfilis and Zuravin (2001) emphasized that risk assessment should assist the worker in isolating factors to determine which families need further intervention. Nearly 20 years earlier Johnson and L'Esperance (1984) had suggested that predictive models of recurrence could help agencies target families who needed more intensive services, thereby reducing the allocation of resources for families who were less likely to experience continued maltreatment.

\section{Defining Child Well Being}

A significant issue in risk assessment decision-making is defining child well being, which does not easily lend itself to observation or classical 
experimental designs. Seaberg (1990) purported that child well being shared kinship with other concepts in child welfare such as "best interests of the child" and "reasonable efforts" (p. 267). While the three concepts (well being, best interests, and reasonable efforts) are abstract and therefore difficult to quantify, each contributes to major decisions regarding children and families' lives. Although professionals often differ on the relative severity of various forms of neglect and abuse there appears to be at least minimal agreement on certain broad domains of child well being, including food, clothing, shelter, medical care, a non-abusive family environment, emotional nurturance and support, supervision, and education. Any such agreement, however, does not generally extend to the criteria for assessing these domains (Wolfe, 1985; Seaberg, 1988).

\section{The Cycle of Abuse}

One of the most consistent findings in child abuse literature is that maltreating parents often report having been abused as children (Garbarino, 1984; McCurdy, 1995). An incorrect conclusion from this finding, however, is that maltreated children always become abusive parents. There are individuals who were not abused as children who become abusive, as well as individuals who were abused as children who do not become abusive (DePanfilis \& Salus, 1992;

Filip, McDaniel, \& Schene, 1992). Parents' overall histories as children do, however, play a large part in how prepared they may be to parent. Characteristics identified in maltreating parents are low self-esteem, low intelligence, ego deficiency, impassivity, hostility, isolation and loneliness, anxiety, depression and apathy, rigidity, fear of rejection, low frustration 
tolerance, inability to control anger, narcissism, fearfulness, immaturity and dependency, mistrustfulness, neuroticism, drug or alcohol abuse, criminal behavior and an excessive need for the child to comply with parental wishes (DePanfilis \& Salus, 1992; English, 1998; McCurdy, 1995). A variety of problems resulting from a lack of skills and knowledge have also been suggested as characteristic of some maltreating parents. These include a lack of parenting skills, problems with coping and self-control, marital difficulties, and a general lack of interpersonal skills (Christensen, Todahl, \& Barrett, 1999; DePanfilis \& Salus, 1992). A lack of knowledge of child development may also result in inappropriate expectations, which, in combination with any one of the previous parental characteristics, may contribute to abusive behavior (DePanfilis \& Salus, 1992).

\section{Life Events and Environmental Factors}

Specific life situations can also increase the likelihood of abuse, such as marital conflict, domestic violence, employment issues, financial difficulties and social isolation. Child abuse can be seen as a problem in parent-child interactions with parental, social and psychological factors playing contributing roles. Environmental factors are often found in combination with child, parent, and family factors (McCurdy, 1995). Seaberg (1990) pointed out that children live predominately in families; therefore, their well being is closely linked with the ability of the family to perform basic family functions.

Certain children are more physically and emotionally vulnerable than others to maltreating behavior. The child's age, and physical, mental, emotional, 
and social development can greatly increase or decrease the likelihood of being abused, depending on the interactions of these characteristics with parental factors previously mentioned. The child's behavior may also be a contributing factor. For example, aversive crying and unresponsiveness can increase the likelihood of abuse. Likewise, hyperactive children or children who are perceived as "different," such as disabled children are at greater risk for abuse (DePanfilis \& Salus, 1992)

Nelson, Saunders, and Landsman (1993), studying neglect $(n=182)$, pointed out that historically considerable resources had been directed to the study of physical abuse, however, little attention had been focused on studying the chronic neglectful family. Demographic characteristics of neglectful families supported by their study included (a) poor hygiene of the children, (b) mental retardation of adults and children, (c) parent-child conflict, (d) child mental illness, (e) truancy, and (f) inadequate child nutrition and medical care. Families identified as chronically neglectful were considerably poorer than the average for their neighborhood. Psychological distresses identified in the chronically neglectful parents included (a) depression, (b) emotional problems, (c) chronic mental illness, and (d) alcohol and drug use. Forty percent of those interviewed reported that they had grown up in a family in which someone had been a heavy drinker. Not surprisingly, $30 \%$ reported a drug or alcohol problem in their home within the previously three years. The multiplicity of problems facing the chronically neglectful can be overwhelming to the service provider. Thus, assessment allows intervention to be targeted toward specific needs and goals. 
Risk Assessment to Improve Clinical Judgment

It is clear that determining which families will abuse is therefore a complex and challenging endeavor. Wald and Woolverton (1990), advocating for improvements in risk assessment instruments, stressed that risk assessment be an ongoing process in child protection work. Supporting this premise, McCurdy (1995) found that the use of risk assessment with voluntary clients at the beginning of services improved the structure and quality of service delivery.

Fuller, Wells, and Cotton (2001), Lyons, Doueck, Koster, Witzky, and Kelly (1999), Magura and Moses (1986), Seaberg (1988) and Wald and Woolverton (1990) cautioned against sole dependence upon a risk assessment score for decision-making. They emphasized that risk scales should be used as part of a thorough assessment in making informed casework decisions. Wald and Woolverton (1990) pointed out that an individual's risk score should not be substituted for good clinical judgment in making casework decisions and asserted that risk assessment should include the likelihood of any future abuse and the likely severity of any harm that would result from such behavior.

McDonald and Marks (1991) reviewed (a) the Alameda County California Re-abuse Assessment Model, (b) the Washington Risk Factor Matrix, (c) the Illinois CANT 17B, (d) the Utah Risk Assessment Model, (e) the Florida Health and Rehabilitation Services Child Risk Assessment Model, (f) the Child Welfare League of America Child Well-being scales, (g) the Child Welfare League Family Risk Scales, and (h) the ACTION for Child Protection-Child Risk Scales. Recall that ACTION for Child Protection Institute assisted with the CQA tool being used 
in Kentucky. They identified 88 variables that assessed the characteristics of children, primary caretakers, families, environment, maltreatment, perpetrator's access to the child, and parent child interaction. All of the instruments reviewed shared the common orientation of focusing on the future. The analysis confirmed that decisions regarding the risk of harm to children involves assessing information gathered from a field of six domains: (a) parent characteristics, (b) environmental factors, (c) parent-child interaction, (d) child characteristics, (e) maltreatment, and (f) perpetrator characteristics. Consensus was not found on the importance of family characteristics. Considerable diversity and ambiguity were found in how the instruments conceptualized and measured the variables. McDonald and Marks (1991) found that only two agencies had used data gathered in the risk-assessment process to assess predictive validity of the variables. McDonald and Marks (1991) concluded that future risk research should try to identify the better predictor patterns, considering whether individual variables, combinations of or interactions of variables or worker's judgments are predictive of future harm to the child.

Although the use of risk assessment in CPS is becoming widespread, McCurdy (1995) called attention to two issues which are central to risk assessment (a) the validity of staff assessments of various risk factors, and (b) the relationship between these risk factors and the potential for abuse. McCurdy (1995), examined 11 prevention programs $(n=569)$ and found that providers made consistent judgments across various risk measures and that these judgments correlated with participants' self reports of potential for physical 
abuse. Macdonald and Macdonald (1999), however remind workers, "if a decision involves risk, then, even when one can demonstrate that one has chosen the unarguably optimal course of action, some proportion of the time the outcome will be sub-optimal" (p. 4).

\section{Assessment Tools}

A review of the literature did not reveal a consensus of support for any one risk assessment tool. Wald and Woolverton (1990) reported that no risk assessment instrument had been developed in a scientific fashion. Specifically, they found no instrument that had been based on research of predictor factors of re-abuse that had been tested through longitudinal research. Neither did they find a study that examined the impact of services in reducing risk. They found that the instruments available had derived factors from two sources: (a) the judgments of experienced workers, and (b) literature reviews that examined those factors generally found to be associated with people who initially abuse or neglect. Wald and Woolverton (1990) concluded their review by calling for (a) instruments that focus on improving clinical judgment, not as actuarial devices, (b) workers to be taught to ask, What is necessary to prevent reoccurrence of behavior? (c) additional research on risk assessment, (d) data to be systematically collected throughout the period of agency involvement, and (e) risk assessment to be tied to case planning.

Seaberg (1988) critiqued the development of Magura and Moses' (1986) "Child Well Being Scales" and cautioned researchers with concerns (a) about Magura and Moses' choice of respondents, with $39 \%$ of the respondents being 
administrators and program directors instead of direct service providers, (b) that $86 \%$ of the respondents were white, (c) about the methodological flaws in the summative scores, (d) about the validity estimation, and (e) about the reliability estimation. Recall that the Child Well Being Scales are a set of standardized client outcome measures specifically designed to evaluate child welfare services (Magura \& Moses, 1986). Seaberg (1988) did state, however, that the use of change scores might have value for program evaluation.

On the other hand, Lyons, Doueck, Koster, Witzky, and Kelly (1999) found that use of the Magura and Moses (1986) scales provided a snapshot of progress when implemented at 6-month intervals. They also found the scales to be useful in clinical decisions, case planning, service planning, and outcome measurement. Gaudin, Polansky, and Kilpatrick (1992), studying the dynamics associated with neglect, field-tested 17 scales of the Child Well Being Scales (Magura \& Moses, 1986), and reported good internal consistency.

Nasuti (1998) studied The Utah Risk Assessment Scales, which were designed to help child welfare staff members assess child well being. The Utah Risk Assessment Scales were designed as a set of behaviorally anchored measures to measure the current behavioral, emotional, and situational status of families to determine the level of danger to a child in terms of serious physical or emotional injury, permanent damage, or death. The Utah Scales consist of 32 separate scales that measure risk across five major areas: (a) parent force, (b) child force, (c) family force, (d) maltreatment force, and (e) intervention force. Fifty-nine percent of the Utah Risk Assessment Scale was based on the Child 
Well Being Scales (Magura \& Moses, 1986) and the Family Risk Scales (Magura, Moses, \& Jones, 1987). The remaining $41 \%$ of the Utah Scales were developed by a CPS steering committee. The purpose of Nasuti's (1998) study was to assess and evaluate data provided by CPS staff members to test the reliability of the Utah Risk Assessment Scales. Data analyses were supportive of expectations, suggesting that the Utah Risk Assessment Scales have adequate levels of internal consistency and interrater reliability. The scales, which focused on a variety of family characteristics across the five identified risk fields, were consistently used by CPS workers to differentiate between varying levels of family functioning and child well being. Holder and Corey (1987) supported this type of ecological approach in assessing child well being as workers needed an understanding of the total family situation if they were to intervene quickly and effectively.

Fuller, Wells, and Cotton (2001) reported on two studies that examined the Illinois Child Endangerment Risk Assessment Protocol (CERAP). The CERAP is an assessment tool designed to guide the protection worker in decision making throughout the life of the case, improve the consistency of practice, and provide workers with a measure of assurance when making safety decisions. Information from the CERAP was examined, as well as other case characteristics that have been shown to be predictive of recurrence. These researchers supported earlier findings that simply summing the number of risk factors was not sufficient-that interactions were too important to ignore. Fuller, Wells, and Cotton (2001) examined the predictors of maltreatment at two distinct 
points in the life of a case, (a) within 24 hours of the investigation initiation, and (b) within 5 days of case opening. Age of the youngest child, single parent household, number of child problems, type of maltreatment and case disposition emerged as the predictors for short-term recurrence of child abuse/neglect. It may well be that the process of completing the CERAP encouraged workers to think about their clients' needs, which lead to improved service delivery. At both milestones, the number of previous indicated reports on the perpetrator and the presence of multiple caretaker problems were indicative of recurrence. Fuller, Wells, and Cotton (2001) called for additional research to include methodology aimed at more effectively capturing the impact of risk and safety assessment.

\section{Summary of Risk Assessment In Child Protective Services}

Based on a review of the literature regarding risk assessment and decision making in child protective services, the use of safety or risk assessment protocol and planning tools appears to improve decisions regarding risk of reoccurrence of child maltreatment. Although the literature does not reflect a consensus on specific causes of maltreatment, there is agreement that child maltreatment occurs as a result of multiple forces that impact the family, interact, and reinforce each other. There does appear to be consensus that additional research is needed on risk assessment and its predictive ability in relationship to recurrence of maltreatment. At this stage the research base does not strongly support one risk assessment tool over another; however, domains which are generally cited as being important in making decisions regarding risk of harm

include (a) parent characteristics, (b) environmental factors, (c) parent-child 
interaction, (d) child characteristics, (e) maltreatment, and (f) perpetrator. The use of risk assessment tools allows workers to structure their interventions around identified risk factors. Literature on risk assessment tools caution against sole dependence on risk assessment scores for casework decisions and stress that risk assessment tools should guide the worker in making informed decisions throughout the life of the case.

\section{Nationwide/Kentucky Child Abuse Statistics}

The Child Abuse Prevention and Treatment Act (CAPTA) was amended in 1988 to direct the Secretary of the Department of Health and Human Services (DHHS) to establish a national data collection and analysis program to make available state child abuse and neglect reporting information. DHHS responded by creating the National Child Abuse and Neglect Data Analysis System (NCANDS), which appears to be the most comprehensive multi-state collection of child welfare data available. However, differences in laws, policies, practice, worker demographics and data collection systems are variables to be considered in multi-state data interpretation. For example, educational requirements for protective service caseworkers and training requirements for foster parents, caseworkers and casework supervisors vary across the nation with pre-service and annual training requirements ranging from none to more than 15 days.

Kentucky's educational requirement for protective service caseworkers is a bachelor's degree in social work or a related field. In compliance with Council on Accreditation standards, related degrees includes psychology, sociology, and human studies. The Federal Children and Families Services Review conducted 
in 2003 was highly complementary of Kentucky's training for new and ongoing workers. According to the DHHS, Administration on Children, Youth and Families (2003), Kentucky's pre-service and ongoing training requirements were described as one of the two best in the nation. The entry-level salary range for caseworkers also varies widely across the nation, with Kentucky's entry level being $\$ 23,064$. Connecticut reported the highest annual entry-level salary at $\$ 43,167$, with the national mean for entry-level salary being $\$ 25,601$. The effectiveness of states' child welfare programs cannot, therefore, be determined by relying exclusively on nationally collected data making cross-state comparisons (Child Welfare League, 2003; U.S. Department of Health and Human Services, Administration on Children, Youth and Families, 2003).

In 2000 an estimated 3 million referrals concerning the welfare of 5 million children were reported to protective service agencies in the United States as alleged victims of child maltreatment. Approximately 879,000 were found to be victims of maltreatment. In 2000, 12 out of every 1000 children were substantiated as victims of child abuse. An average of 2,400 children were found to be victims of child abuse each day.

Victimization rates declined as age increased. The youngest and most vulnerable children -children under 3-had the highest victimization rate. Ethnically, the victims were 51\% white, 25\% African American, and 15\% Hispanic. An estimated 1,200 children known to CPS died of abuse and neglect in 2000. Forty-three percent of these children were less than 1 year of age. Child treatment fatalities were more frequently associated with neglect than with 
other types of maltreatment, including physical abuse. Not all victims of abuse and neglect are reported to CPS and not all reports are verifiable, therefore, the statistics presented probably under-present the true scope of child maltreatment (Goldman, \& Salus, 2001; U.S. Department of Health and Human Services, Administration on Children, Youth and Families, 2003).

Factors which may affect numbers of children involved in abuse investigations, as well as levels of substantiation for child abuse/neglect within a given state, include screening standards for referrals, the state's definition of abuse and neglect, and criteria for substantiation (Appendix D). Approximately $50 \%$ of reports are received from other professionals, i.e. school personnel, day care providers, and police. According to the DHHS, Administration on Children, Youth and Families (2001), the number of children reported for abuse and neglect rose more than $16 \%$ between 1990 and 1996, while the child population grew only $7.6 \%$ during the same years. Kentucky's substantiated or indicated reports for physical abuse, sexual abuse and/or neglect, over the past 10 years, are significantly higher than the national mean, with Kentucky's children being nearly twice as likely to have a substantiated incident of maltreatment as children nationally (Table 1).

In compliance with federal child and family service review guidelines, the Commonwealth of Kentucky Child and Family Services Statewide Assessment was submitted to the U. S. Department of Health Human Services in January 2003. The child and family services review (CFSR), authorized by the 1994 Amendments to the Social Security Act and administered by the Children's 
Table 1

Number of Child Victims of Physical Abuse, Sexual Abuse and Neglect 1990, 1996, and 1999

\begin{tabular}{|c|c|c|c|c|c|c|}
\hline (n) & & 990 & 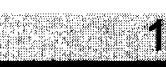 & 96 & & 99 \\
\hline & $\overline{\mathrm{KY}}$ & National & $\overline{\mathrm{KY}}$ & National & $\overline{\mathrm{KY}}$ & National \\
\hline $\begin{array}{l}\text { Child Population } \\
\text { Under } 18\end{array}$ & 945,295 & $64,1777,430$ & 970,587 & $69,107,815$ & 965,528 & $70,199,325$ \\
\hline $\begin{array}{l}\text { Children Physically } \\
\text { Abused }^{2}\end{array}$ & 5,911 & 188,960 & 7,132 & 229,300 & 5,154 & 166,626 \\
\hline $\begin{array}{l}\text { Children Physically } \\
\text { Abused Per } 1000 \\
\text { Children in } \\
\text { Population }\end{array}$ & 6.3 & (1) & 7.3 & 3.3 & 5.3 & 2.6 \\
\hline $\begin{array}{l}\text { Children Sexually } \\
\text { Abused }\end{array}$ & 2,075 & 120,732 & 2,042 & 119,515 & 1,436 & 88,238 \\
\hline $\begin{array}{l}\text { Children Sexually } \\
\text { Abused Per } 1000 \\
\text { Children in } \\
\text { Population }\end{array}$ & 2.2 & 2.3 & 2.1 & 1.7 & 1.5 & 1.4 \\
\hline $\begin{array}{l}\text { Children } \\
\text { Neglected }\end{array}$ & 14,258 & 343,312 & 16,994 & 500,110 & 11,887 & 437,540 \\
\hline $\begin{array}{l}\text { Children Neglected } \\
\text { Per } 1000 \text { Children } \\
\text { in Population }\end{array}$ & 15.1 & 9.3 & 17.5 & 8.3 & 12.3 & 7.0 \\
\hline
\end{tabular}

Bureau, Administration for Children and Families, U.S. Department of Health and Human Services is a collaborative review by the Federal government and State child welfare agencies to assess each State's capacity to promote positive outcomes in the mandated ASFA areas of child safety, permanency, and well being. The CFSR Assessment enables staff to identify and expand upon areas of strength, and to determine areas of need that will require future focus. The reviews emphasize accountability with a strong emphasis on using the 
review to drive program improvement (Kentucky Cabinet for Families and Children, 2003a).

The safety outcome data from the CFSR Assessment revealed that Kentucky's rates of substantiation for child maltreatment cases remained constant between $29.2 \%$ and $29.1 \%$ for calendar years $1999-2001$. Kentucky exceeded the national standard $(6.1 \%)$ for recurrence of maltreatment in each of the past three years with recurrence of maltreatment ranging from $8.3 \%$ to $8.6 \%$. There is a wide variance of repeat maltreatment across the state, with rates ranging from $3.9 \%$ to $15.4 \%$ (Table 2 ). Regions from the eastern part of the state tend to have the higher rates of maltreatment (in bold in Table 2). Eastern Kentucky contains some of the poorest counties in the United States; thus, the likelihood of child maltreatment may be higher due to geographic isolation, economic stresses, and poverty. One of the causal factors identified in the CFSR Assessment for repeat maltreatment was under assessing by workers, particularly in areas of substance abuse, domestic violence, and indicators of poor mental health (Kentucky Cabinet for Families and Children, 2003).

A number of cultural and social factors were identified in the CFSR Assessment as having the potential to influence the safety profile (a) Kentucky ranks $44^{\text {th }}$ out of the 50 states and District of Columbia in percentage of persons under 18 living in poverty, (b) the median household income is $\$ 32,843$, which places $16.5 \%$ of Kentucky families below the poverty limit, (c) Kentucky ranks $23^{\text {rd }}$ out of the 50 states and the District of Columbia for percentage of children in 
Table 2

Distribution of Recurrence of Maltreatment 2001 by Region

\begin{tabular}{lcc}
\hline \multicolumn{1}{c}{ Region } & $\begin{array}{c}\text { Percentage of } \\
\text { Unique Children }\end{array}$ & $\begin{array}{c}\text { Number of } \\
\text { Unique Children }\end{array}$ \\
\hline Big Sandy & 15.4 & 63 \\
Kentucky River & 13.3 & 75 \\
Fivco & 10.4 & 28 \\
Lake Cumberland & 10.2 & 49 \\
Lincoln Trail & 9.9 & 42 \\
Gateway/Buffalo Trace & 8.9 & 32 \\
Green River & 8.7 & 43 \\
Barren River & 7.1 & 39 \\
Pennyrile & 7 & 23 \\
Northern Kentucky & 6.9 & 39 \\
KIPDA Jefferson & 6.9 & 113 \\
Cumberland Valley & 6.8 & 36 \\
Bluegrass Rural & 5.7 & 48 \\
KIPDA Rural & 4.8 & 12 \\
Bluegrass Fayette & 4.6 & 18 \\
Purchase & 3.9 & 11 \\
Total & 8.6 & 671 \\
\hline Bold & & \\
\hline
\end{tabular}

Bold indicates Appalachian Regions in Eastern Kentucky

From "Commonwealth of Kentucky Child and Family Services Statewide Assessment," by Kentucky Cabinet for Families and Children. Report submitted to U.S. Department of Health and Human Services during Children and Families Service Review, Kentucky, 2003. Adapted with permission of author.

single parent households, (d) $74.6 \%$ of residents hold only high school diplomas, and (e) Kentucky has an increasing drug problem. To identify and address these multiple barriers to family safety and self-sufficiency, Kentucky acknowledged a 
need for research and resource development in its five-year CAPTA plan. The CFSR Assessment specifically listed the area of repeat maltreatment as needing further examination to determine why the rate of repeat maltreatment has remained consistently above the national standard for the past 3 years. On the positive side, the CFSR Assessment identified reforms in child safety policies or practice occurring in the state that may have a had a positive impact on child safety: (a) comprehensive family services, (b) accreditation of child protection programs, (c) solution-based casework model, (d) family team meetings, (e) multiple response, (f) TWIST, and (g) the training academy for workers (Kentucky Cabinet for Families and Children, 2003).

\section{Kentucky's Solution-Based Casework Model}

The 1980 s brought many changes to Kentucky's Department of Social Services, including the implementation of family-based services, a specialized service that focuses the intervention on the family rather than only the child or the parents. Prior to that time, Kentucky had utilized a deficit model of casework, which focused on identifying problems and needs within the individual or family. Workers were considered experts and their task was to provide clients with direction on overcoming their problems. Families and individuals were often referred to as dysfunctional. Clients were viewed as "service recipients rather than active partners" (Christensen, Todahl, \& Barrett, 1999, p. 7). Little attention was given to identification of individual or family strengths. In contrast, familybased casework taught that the best way to provide services to a child was by strengthening and empowering the family as a unit. Family based case work 
stressed that by involving the family as a partner in the decision-making and goal setting process and by building on the family's strengths and existing resources, the family was empowered with competency to take control of their lives (Berg, 1994; Christensen, Todahl, \& Barrett, 1999).

In the 1990s, Christensen developed Solution-based casework in collaboration with community service providers and the Kentucky Department of Social Services, to "provide a conceptual road map for establishing solution focused partnerships with families" (Christensen \& Todahl, 1996, p. 3). According to Christensen, Todahl, and Barrett (1996), solution-based casework utilizes concepts from family development theory, solution-focused therapy, and relapse prevention theory. Solution-based casework (a) offers caseworkers and therapists concrete planning direction, (b) identifies high-risk behavior, and (c) prepares families to prevent relapse.

Christensen, Todahl, and Barrett (1999) emphasized that worker/family partnerships should focus on specific problematic behaviors, anchored in everyday life events within the family, to prevent problem relapse. The worker and family examine why the family's previous attempts to solve the problem have failed and then create a partnership that focuses on problem solving. Solutionbased casework anchors itself around three tenets: (a) the commonality of challenges in family life, (b) the importance of focusing casework on those everyday life challenges that are high risk for families, and (c) the need to focus individual skill development on preventing relapse in high risk situations (Christensen \& Todahl, 1996; Christensen, Todahl, \& Barrett, 1999). 
In the field of child and adult protection, recurrence of maltreatment is a significant issue. Recall that Kentucky's rate of repeat maltreatment exceeded the national standard in 1999,2000 , and 2001 . To help clients manage high-risk behaviors that have led to previous maltreatment, clients are taught to identify high-risk situations and early warning signals. They are also taught to utilize skills in (a) avoiding risk situations, (b) interrupting risk situations, and (c) escaping risk situations to successfully manage relapse (Christensen, Todahl, \& Barrett, 1999). Successful relapse prevention focuses on specific events and clients' abilities to manage their behaviors in response to those events. The pattern of family interaction is emphasized and workers are taught to form partnerships with families to discover destructive patterns of behavior. Assessment is based on the shared belief that the family can meet almost any challenge if they can just figure out what went wrong. Once the destructive patterns are identified, the family can develop family and individual plans of action to manage the high-risk behaviors.

\section{Summary of Literature Review}

With a million children a year being abused, child protective agencies are confronted with a need for preventive, as well as protective services. A child's risk of maltreatment is the primary concern in the decision of whether a child can safely remain in the home. Child well being can also be used as a measure of program success or failure (English, 1998; Nausti, 1998). Yet, child well being is an elusive concept, difficult to define and measure. Child protective workers 
interested in improving service delivery in protective services need tools for assessing child well being.

Kentucky's Continuous Quality Assessment (CQA) is an assessment tool to guide workers in the collection, organization and analysis of information to better determine the safety, risk, and needs of families and children. Assessment, as the cornerstone to the social work relationship, is essential to problem definition and the development of the service plan in any social work environment. Assessment in protection work is of particular significance because it involves determining the level of risk for adults and children. Risk assessment, therefore, is a process for assessing the likelihood that a parent or caregiver will harm a child in the future. This study enhances a public child welfare agency's understanding of child protective decision-making and risk assessment. More specifically, this study examined the CQA and its effectiveness in assessing risk, as measured by the reoccurrence of abuse.

Drawing from the literature review I accept the following foundational premises for this dissertation:

1. Evaluating the likelihood of maltreatment is a key decision in the child protective process (DePanfilis, 1996; English, 1998; Haskett, Scott, \& Fann, 1995; McDonald \& Marks, 1991; Seaberg, 1988).

2. Kentucky's Solution-based casework approach provides a conceptual road map for establishing solution-focused partnerships with families (Christensen, Todahl, \& Barrett, 1999). 
3. Casework is not effective when (a) the client's perception of their problem is not included in the assessment and subsequent casework, (b) strengths of the family are not considered, and (c) it is assumed that the problem lies solely within the individual (Shireman, Grossnickle, Hinsey, \& White, 1990; Wood, 1978).

4. Solutions to problems of children and families should be grounded in families' individual strengths and needs (Christensen, Todahl, \& Barrett, 1999; Dattalo, 1995; Wood, 1978).

5. Recidivism is an accessible measure that agencies should consider in evaluative research (Claburn, Magura, \& Chizeck, 1977).

6. Outcome measures should inform agency decisions (Magura \& Moses, 1980).

7. Regardless of how workers count or measure successes, their concern cannot stop with simply knowing what works; they also need to know for whom it worked (Giovanni, 1982).

8. Risk assessment is an ongoing process in child protective work and an individual's risk score should not be substituted for good clinical judgment in making casework decisions (Wald \& Woolverton, 1990).

9. Summing the number of risk factors is not sufficient, as interactional patterns of risk factors are too important (Fuller, Wells, \& Cotton, 2001). In 1973, Fischer challenged the social work profession to demonstrate the effectiveness of casework (Fischer, 1973a). As we enter the 21st century, states continue to struggle with demonstrating effectiveness of their programs. Results 
from research questions on risk assessment as a measure of effectiveness add to the body of knowledge on measurable outcomes for the Cabinet for Families and Children, which will enhance its ability to improve service delivery to the families and children of Kentucky.

Thus, the overarching research question of this study is: What is the relationship between child protection services provided by the Kentucky Department of Protection and Permanency and risk of maltreatment?

\section{Research Questions}

To answer the overarching question, five research questions were examined:

1. What are the relationships of change from the level of risk measured by the first Continuous Quality Assessment (CQA) at case opening to the level of risk measured by the last CQA at case closure?

2. What is the relationship between the levels of risk as assessed by the CQA and repeat maltreatment for child protective service cases following case closure?

3. What are the relationships between services provided by the Kentucky Department of Protection and Permanency and repeat maltreatment following case closure?

4. What are the relationships between change in the level of risk and case manager demographics for child protective cases?

5. What are the relationships between repeat maltreatment following case closure and case manager demographics for child protective cases? 


\section{CHAPTER III}

\section{METHODOLOGY}

This chapter will outline (a) the research design, (b) the population, (c) operationalization of dependent and independent variables, d) data collection and research instruments, e) confidentiality and informed consent, and e) data analysis procedures.

\section{Research Design}

In this quantitative study of risk assessment and recidivism, a modified onegroup pretest posttest design was used:

\section{$\mathrm{O}_{1} \times \mathrm{O}_{2} \mathrm{O}_{3}$}

where $0_{1}$ represents the first CQA completed, generally during the initial investigation of the referred maltreatment incident, $\mathbf{0}_{2}$ represents the last CQA prior to case closure and $\mathrm{O}_{3}$ equals the number of times maltreatment was reported from case closure (closed between 1-01-02 and 6-30-02) to 6-30-2003. The intervention, solution-based casework, is represented by $\mathbf{X}$. A chart review of existing data on closed CPS cases provided a measurement of the dependent variable before and after the intervention. Rubin and Babbie (1997) refer to this design as preexperimental. Although this design did not control for rival hypotheses, it did control for differential selection, since the participants were the same for both pretest and posttest (Campbell \& Stanley, 1963; Grinnell, 1997). 
Mortality was not a threat to internal validity because it is the differential dropout between groups that causes the threat and in this study all cases were considered as one group (Campbell \& Stanley, 1963; Grinnell, 1997).

The first dependent variable, risk of maltreatment, was defined as the level of risk as measured by the CQA. Low scores mean less risk and higher scores indicate the child is at greater risk. CQA scores at the beginning and end of the current episode of casework service established a cumulative score, as well as individual scores in each of the identified risk areas, thus establishing correlation and time order as a foundation for future studies (Rubin \& Babbie, 1997).

The second dependent variable, repeat maltreatment, was defined as the number of referrals of maltreatment received from case closure to 6-30-03. This included referrals found to be (a) substantiated, (b) family in need of services, or (c) unsubstantiated. Kentucky Revised Statues define criteria for referral acceptance (Appendix C). English, Marshall, Brummel, and Coghlan (1998) support the inclusion of unsubstantiated referrals and point out that many factors influence whether a referral is substantiated, factors that at times have little to do with whether maltreatment actually occurred. They suggest that studies that rely exclusively on substantiated recurrence may yield different predictors than studies that examine the more inclusive variable of re-referrals. Thus, they argue it is appropriate to examine both classifications.

\section{Population}

Cases included in this chart review were drawn from the TWIST database. Recall that TWIST is Kentucky's electronic case management system, which 
contains information on all Kentucky Department of Protection and Permanency child protective cases. The TWS-M144 (Pre and Post CQAs for CPS), a monthly listing of all Kentucky child protective service cases closed during the previous month, was used to identify cases for the study. The February through July 2002 TWS-M144 listings identified 3,235 cases closed during the first 6 months of 2002. Cases excluded from analysis $(n=406)$ were (a) cases with an opening cumulative score of 0 , and (b) cases with an opening CQA and closing CQA completed on the same day. These two categories of cases were not mutually exclusive. Cases excluded from the study accounted for $12.6 \%$ of the original identified study population.

The length of time the cases in the study were open for service ranged from less than 1 month to 69 months. Of the 2,829 cases accepted for the study, opening dates of service ranged from $9-03-96$ to $5-31-02-3.5 \%$ of the cases were open less than 3 months and 3.5\% were open longer than 5 years. Cases open for 1 month or less were generally investigations that took longer than 45 days to complete. They were not open for service beyond the investigation. Only $20 \%$ of the cases were open for more than 24 months.

The primary service programs of the cases included in the study were: neglect, placement, physical abuse, general family, community/juvenile, dependency, sexual abuse, and emotional abuse. Cases with primary programs of neglect, physical abuse, or placement accounted for $76 \%$ of the study cases. Many of the cases had more than one service area identified, however the TWS- 
004 is designed to report only the service program designated as primary by the worker.

\section{Dependent and Independent Variables}

The primary dependent variables in this study are repeat maltreatment and risk of maltreatment (Table 3). Repeat maltreatment as defined for this study is not limited to a recurrence of the same type of abuse or neglect. Repeat maltreatment will include substantiated, unsubstantiated, and family in need of service findings. Risk of maltreatment is operationally defined as the level of risk as measured by the CQA. The CQA is based on an ecological model of child maltreatment, which considers severity of the maltreatment, the child, caregiver, and environment in which the child lives to be associated with the likelihood of maltreatment. Changes in risk of maltreatment are measured by the (a) cumulative rating on the CQA, (b) scores in the seven identified risk domains, and (c) scores in the safety and well being factors.

When the perpetrator is considered familial, the CQA contains the following risk domains (a) maltreatment/presenting problem, (b) abuse/neglect conditions, (c) sequence of events, (d) safety screening checklist, (e) family development stages and tasks, (f) family choice of discipline, (g) adult patterns of behavior, (h) child/youth development, (i) family support, (j) risk rating, and (h) summary (Appendix A). Familial is defined as anyone who has continuous access to the child in a home environment, including boyfriends, extended family members, and babysitters. Reports that have a non-familial, out of home perpetrator, may use an abbreviated version of the assessment. The abbreviated assessment 
Table 3

Dependent and Independent Variables, Operationally Defined with Level of

Data

\begin{tabular}{|c|c|c|c|c|}
\hline Variable & $\begin{array}{l}\text { Dependent or } \\
\text { Independent }\end{array}$ & Operationally Defined & $\begin{array}{l}\text { Level of } \\
\text { Data }\end{array}$ & $\begin{array}{c}\text { Source of } \\
\text { Data }\end{array}$ \\
\hline $\begin{array}{l}\text { Risk of } \\
\text { Maltreatment }\end{array}$ & Dependent & $\begin{array}{l}\text { The CQA cumulative and individual } \\
\text { risk factor scores }\end{array}$ & Interval & TWS-M144 \\
\hline $\begin{array}{l}\text { Repeat } \\
\text { Maltreatment }\end{array}$ & Dependent & $\begin{array}{l}\text { The number of referrals of } \\
\text { maltreatment (substantiated and } \\
\text { unsubstantiated) made to } \\
\text { Protection and Permanency in } \\
\text { the year following case closure }\end{array}$ & Ratio & $\begin{array}{l}\text { TWIST } \\
\text { case files }\end{array}$ \\
\hline $\begin{array}{l}\text { Case Status } \\
\text { Domain }\end{array}$ & Independent & $\begin{array}{l}\text { County and region of case } \\
\text { Length of time case was open } \\
\text { Length of time case previously open } \\
\text { Primary program area at case } \\
\text { closure, i.e. physical/sexual } \\
\text { abuse or neglect } \\
\text { Number of referrals in TWIST at } \\
\text { case closure, substantiated/ } \\
\text { unsubstantiated } \\
\text { Number of Targeted Case } \\
\text { Management contacts in last } \\
\text { month, } 2 \text { months, } 3 \text { months } \\
\text { Length of time between last case } \\
\text { plan and case closure } \\
\text { Length of time between last face to } \\
\text { face contact and case closure } \\
\text { Case selected for review by COA } \\
\text { reviewers }\end{array}$ & $\begin{array}{c}\begin{array}{c}\text { Nominal } \\
\text { Ratio } \\
\text { Ratio } \\
\text { Nominal }\end{array} \\
\text { Ratio } \\
\text { Ratio } \\
\text { Ratio } \\
\text { Ratio } \\
\text { Nominal }\end{array}$ & $\begin{array}{l}\text { TWS-M144 } \\
\text { TWS-M144 } \\
\text { TWS-M004 } \\
\text { TWS-M004 } \\
\text { TWS-M004 } \\
\text { TWS-M004 } \\
\text { TWS-M144 } \\
\text { TWS-M004/ } \\
\text { COA listing }\end{array}$ \\
\hline $\begin{array}{l}\text { Workerl } \\
\text { Supervisor } \\
\text { Demographics }\end{array}$ & Independent & $\begin{array}{l}\text { Gender } \\
\text { Length of time with agency to } \\
\text { nearest } 1 / 2 \text { year } \\
\text { Case manager position } \\
\text { Bachelor or Master's Degree } \\
\text { Area of study: social work, } \\
\text { sociology, psychology, family } \\
\text { studies, corrections, other }\end{array}$ & $\begin{array}{l}\text { Nominal } \\
\text { Ratio } \\
\text { Nominal } \\
\text { Nominal } \\
\text { Nominal }\end{array}$ & $\begin{array}{l}\text { COA listing } \\
\text { COA listing } \\
\text { TWS-M004 } \\
\text { TWS-M004 } \\
\text { COA listing }\end{array}$ \\
\hline $\begin{array}{l}\text { Recidivism } \\
\text { Demographics }\end{array}$ & Independent & $\begin{array}{l}\text { Length of time between case } \\
\text { closure and new incident of } \\
\text { maltreatment } \\
\text { Number of incidents of } \\
\text { maltreatment in } 12 \text { months } \\
\text { following case closure } \\
\text { Number of children re-referred } \\
\text { Gender of children } \\
\text { Age of children }\end{array}$ & $\begin{array}{l}\text { Ratio } \\
\text { Ratio } \\
\text { Ratio } \\
\text { Nominal } \\
\text { Ratio }\end{array}$ & $\begin{array}{l}\text { TWIST } \\
\text { case files } \\
\text { TWIST } \\
\text { case files } \\
\text { TWIST } \\
\text { case files } \\
\text { TWIST } \\
\text { case files } \\
\text { TWIST } \\
\text { case files }\end{array}$ \\
\hline
\end{tabular}


includes (a) maltreatment/presenting problem, (b) sequence of events, (c) abuse/neglect conditions, and (d) summary screens. The summary stresses the protective capacity of the parent/caretaker and what is being done to ensure the safety of children. The worker assigns a risk rating of 0 to 4 in each of the risk domains. A risk classification is generated based on the total risk score (a) high risk $=20-28$ points, $($ b) significant risk $=14-19.9$ points, $(c)$ moderate risk $=7-$ 13.9 points, and (d) low risk $=0-6.9$ points. Inter-rater reliability of the assessment instrument is enhanced by the identification of anchors for each of the risk factors (Appendix A) (Kentucky Cabinet for Families and Children, 2003). The domains of the independent variables in this study were case status, recidivism demographics and worker demographics. Each of the domains is operationally defined by a listing of individual variables (Table 3).

The level of data and source is provided for each of the identified variables.

\section{Data Collection and Research Instruments}

Data were collected through a review of TWIST reports, chart files and Council on Accreditation staff listing. TWIST reports in the analysis included (a) TWS-M120 (Referral recidivism), (b) TWS-M144 (Pre and Post CQAs for CPS), and (c) TWS-M004 (Active Case Listing). For analysis, data were moved from the individual TWIST reports in Excel to one data set in SPSS. The Risk Assessment Research Chart Review Form (Appendix D) was developed to collect information from the case records and management reports about (a) the change in the amount of risk assessed in the family, (b) case status variables, (c) occurrence and demographics of maltreatment following case closure, (d) case 
service elements, and (e) worker demographics. Analysis of these data will inform service providers and agency personnel about the effectiveness of services provided.

Early examination of the data revealed that the TWS-M120 was inadequate for gathering a complete picture of case recidivism. Low recidivism numbers led to the discovery that the TWS-M120 was not designed to report on the finding, "family in need of services". The statewide implementation of the Multiple Response System (MRS) on June 18, 2001 introduced a differential approach to addressing reports of maltreatment, based on level of risk at intake. Reports determined to hold low risk are tracked as family in need of services. Moderate or high-risk cases, including all reports of sexual abuse, are tracked as investigations. Reports that do not meet criteria (Appendix C) are linked to local resources or law enforcement if non-caretaker maltreatment is alleged. The multiple response approach allows the agency to offer preventive services to low risk families, without the stigmatism of an abuse finding. The TWS-M120 reports only on referrals with a "substantiated/unsubstantiated" finding. Thus to ensure that all episodes of repeat maltreatment were included in the analysis, a chart review of all 2,829 individual TWIST cases was completed. Using the master case listing to identify all cases in the population, the referral screens of each case were examined. Data were recorded on the Risk Assessment Chart Review Form for all reports of maltreatment (Appendix D). Resource linkages (service request with no allegation of maltreatment) and law enforcement 
referrals (alleged perpetrator of maltreatment not in a care taking role) were not included in the analyses.

Data for risk of maltreatment were gathered by reviewing TWS-M144 reports (Pre and Post CQAs for CPS). In addition to identifying the opening and closing dates of service for each case, the TWS-144 provided worker/supervisor demographics, and scores (cumulative and individual risk fields) for the first and last CQA for each case. Completion instructions (Appendix A) for the CQA direct workers to rate the risk domains by reviewing the set of anchors designated for each domain, beginning with the extreme and continuing down the listing until they find a statement applicable to the family. The rating of the first applicable statement becomes the rating for the domain (Appendix A).

The TWS-M004 (Active Case Listing) provided information about the case status domain and worker demographics. Information gleaned from the TWSM004 included supervisor and worker demographics, primary program of service, date of last face to face visit with family, date of last case plan, date case was opened and closed for a prior episode of treatment, number of active individuals in the case, and number of referrals in case. COA staff listings provided worker demographic information that was not available on the TWS-M004.

\section{Issues of Confidentiality/Informed Consent}

In this study there were no foreseeable risks to human subjects. The study required no manipulation of subjects and examined only closed cases; therefore, there was no manipulation or withholding of services. 
The identity and privacy of persons served were safeguarded in all phases of the research. TWIST reports utilized for analysis contained case names and case numbers, however, results are reported in aggregate form only. No data in personally identifying form was released to anyone outside the research team. Identifying information was maintained in a locked office. One of the researcher's primary job responsibilities as a regional treatment specialist for the Cabinet for Families and Children is case review for compliance with COA standards and ASFA mandates. With the exception of the statewide worker demographic data, the data to be analyzed in this dissertation are data that the researcher routinely uses in her day-to-day work responsibilities.

The Commonwealth of Kentucky Institutional Review Board in accordance with 920 KAR 1:060 Section 2(3)(d), has determined that this dissertation is exempt from review by the IRB pursuant to 45 CFR 46.101(b)(4) and 46.101(b)(5). Approval was granted on April 15, 2002 for research activities (Appendix E). The University of Louisville Institutional Review Board in accordance with 45 CFR 46.101 (b) 2 , has determined that this dissertation is exempt from review by the Human Studies Committee. Approval was granted on October 21, 2002 for research activities (Appendix F).

\section{Data Analysis}

The goals of this quantitative study were to (a) enhance a public child welfare agency's understanding of CPS decision-making and risk assessment, and (b) add to the body of knowledge on measurable outcomes in child welfare. The goal of data analysis was to provide both state and regional feedback on the 
CQA tool being used by Kentucky child protective workers to assess risk in child protective cases.

The final report for the Kentucky Child Family Services Review (CFSR) found that Kentucky did not substantially achieve Safety Outcome 1 (Children are first and foremost protected from abuse and neglect) or Safety Outcome 2 (Children are safely maintained in their homes whenever possible and appropriate) (U.S. Department of Health and Human Services, Children's Bureau, 2003). A favorable finding, however, was Outcome 2/ltem 4 (Reducing risk of harm to children), was rated as a strength. Kentucky's CFSR Statewide Assessment (Kentucky Cabinet for Families and Children, 2003) identified the CQA as a practice that had been implemented to reduce the recurrence of maltreatment and Kentucky's Performance Improvement Plan (PIP), submitted in response to the CFSR findings, highlighted continuous quality improvement as a goal for achieving ASFA mandated outcomes. Thus, Kentucky protective service workers and agency administrators need to know if the scores on the CQA can be used (a) as a measure of child risk of maltreatment, and (b) as a measure of effectiveness for a public welfare agency.

Accordingly, research questions were designed to provide Kentucky with additional data for quality improvement of service delivery and assessment. Prior to the exploration of the research questions, however, demographics of study and Kentucky populations are presented (Chapter 4) to allow the reader to place the study findings within the context of their environment. 
Following the overview of state demographics, data analysis and findings are presented under three broad categories (a) Change (research question 1), (b) Repeat Maltreatment (research questions 2 \& 3) and (c) Case Manager Demographics (research questions $4 \& 5$ ). Frequency distributions created on each of the variables allowed data to be viewed for accuracy and provided a visual display of data through graphs and charts for increased understanding of the data. Data reduction was utilized to reduce unmanageable details to manageable summaries. A mean was computed on variables with interval or ratio levels of measurement. The means were charted to provide a visual picture of the testing results. Inferential statistics allowed inferences to be made about clients within the population from which the sample was drawn. Paired t-testing, independent t-testing and analysis of variance (ANOVA) provided information on client changes and differences. Chi-square analysis was used to examine relationships between the variables.

\section{Change}

Huebner (2002), completing reliability analysis on the CQA found the alpha coefficients of internal consistency to be (a) overall .79 , (b) safety risk factor .86 and (c) well being risk factor .53 . Following Huebner's recommendation that future analyses consider these findings, data analyses on change began with the replication of Huebner's reliability analysis. Huebner's findings were supported.

Data analyses then moved to address the individual research questions. To address research question 1 (What are the relationships of change from the 
level of risk measured by the first CQA at case opening to the level of risk measured by the last CQA at case closure?), data were obtained at all levels of measurement (Table 3). Paired t-testing allowed a comparison of overall CQA means between opening and closing by (a) safety risk factor, well being risk factor and cumulative risk score, (b) program area, (c) region, and (d) case manager/supervisor demographics to determine if there was a significant difference. ANOVA testing was performed to look at the different independent variables and to examine the amount of variance each variable contributed. The Pearson product-moment correlation ( $r$ ) with an alpha set at .001 was used to determine strength and direction of relationships between the CQA safety factor, the well being factor, and change in CQA score between opening and closing the case. To accommodate the Pearson $r$, the 5-point risk ratings (Likert scales) were treated as interval data (Likert, 1932). The association between all nominal independent variables and change was examined by using Chi-Square testing.

\section{Repeat Maltreatment}

To address research questions 2 and 3 (What is the relationship between the levels of risk as assessed by the CQA and repeat maltreatment for child protective service cases following case closure? and What are the relationships between services provided by the Kentucky Department of Protection and Permanency and repeat maltreatment following case closure?), data were obtained at all levels of measurement (Table 3). Much of the data for this question was nominal. The dependent variable, repeat maltreatment, was examined by considering (a) the presence of subsequent referrals following case 
closure, (b) the number of subsequent referrals of maltreatment from the date of case closure until June 30,2003 , including substantiated, unsubstantiated, or family in need of services, (c) the number of referrals in the case at the time of case closure, and (d) treatment episodes prior to the current episode of treatment. Frequencies were used to highlight (a) cases with a prior treatment episode, (b) means of months between case closing and reopening, and (c) means of months cases were previously open. Frequencies were also used to highlight data on cases with maltreatment since closure of the most current treatment episode. Differences between groups, i.e. region and amount of recurrent maltreatment, were examined with ANOVAs. The association between nominal independent variables and recurrence of maltreatment was examined by using Chi-Squares. The aim of this analysis was to explore relationships and identify possible predictors of risk of maltreatment in an exploratory sense, but not as a part of a confirmatory process.

\section{Case Manager Demographics}

Findings from questions 1,2 , and 3 , specific to case manager/supervisor demographics, were used to address research questions 4 and 5 (What are the relationships between change in the level of risk and case manager demographics for child protective cases? and What are the relationships between repeat maltreatment following case closure and case manager demographics for child protective cases?) In addition frequencies were used to highlight distributions of worker/supervisor differences in (a) area of study, (b) highest educational degree, (c) years of experience, and (d) position. 
The data from this inductive study inform the Cabinet about risk assessment and recidivism, thereby adding to the Cabinet's knowledge base on mandated ASFA outcomes. Relationships were explored and possible predictors of maltreatment identified. Chapter 4 will present the results from statistical analyses of this study and the final chapter will present implications of the research for child welfare, as well as for the Cabinet. 


\section{CHAPTER IV}

\section{FINDINGS}

This chapter reports the statistical techniques used to analyze the data and the results obtained. Presentation of findings is organized around the research questions. Prior to the exploration of the research questions, demographics of the study and Kentucky populations will be presented to allow the reader to consider the findings in context.

\section{Demographics: Kentucky and Study Populations}

The Kentucky Cabinet for Families and Children (CFC) is divided into 16 service regions, each composed of 1 to 16 counties (Figure 1). Services

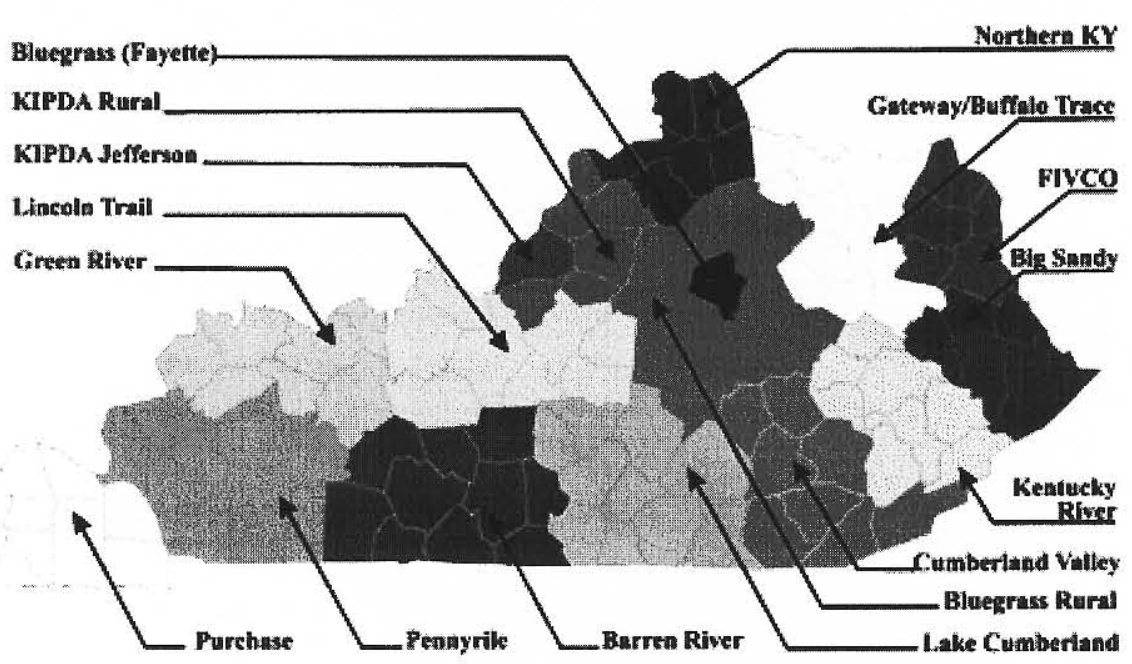

Figure 1. Service regions of the Cabinet for Families and Children. 
are provided from the agency's central office in Frankfort, the 16 regional offices, and more than 200 local offices. Regional offices administer programs for families and children and manage the fiscal and human resource needs of their constituents. Urban areas of the state are located in the Green River, KIPDA Jefferson, Bluegrass Fayette, Pennyrile, and Northern Kentucky regions. The Appalachian Regional Commission classifies the vast majority of counties in the Lake Cumberland, Cumberland Valley, Kentucky River, Big Sandy, Gateway/Buffalo Trace, and Fivco regions as Appalachian Counties. The percentage distribution of the 2,829 closed cases under study was equitable to the percentage distribution of the state population in the service regions (Table 4). The cases were widely distributed across the state, with 118 of the state's 120 counties represented in the study population-Gallatin and Robertson Counties had no cases in the study. The distribution of closure dates for study cases, ranging from January 2002 to June 2002, was unremarkable with each month having between $16 \%$ and $17 \%$ of the total study population.

According to the 2000 census, Kentucky has an overall population of $4,041,769$, ranking $25^{\text {th }}$ among the states. Race of the state's population is reported as (a) Caucasians 90.1\%, (b) African Americans 7.3\%, (c) Asians $0.7 \%$, (d) Hispanics $1.5 \%$, and (e) mixed heritage or not reporting ethnicity $1.6 \%$. The average size of the Kentucky household is 3 persons and nearly $25 \%$ of the population is under 18 . Disturbingly, only $59.1 \%$ of the state's adult population has at least a high school diploma. Southeastern regions Big Sandy, Lake Cumberland, Kentucky River, and Cumberland Valley reported less than $50 \%$ of 
their adults having at least a high school diploma (bolded in Table 4) and over $35 \%$ of their population is under 18 (Table 4). Not surprisingly, the lowest

\section{Table 4}

\section{Distribution of Cases by Region with Regional Demographics}

\begin{tabular}{|c|c|c|c|c|c|c|}
\hline Region & $\begin{array}{l}\text { Frequency } \\
\text { of } \\
\text { Closed } \\
\text { Cases } \\
\text { In study }\end{array}$ & $\begin{array}{c}\text { Percentage of } \\
\text { Study } \\
\text { Population } \\
\text { (Closed Cases) }\end{array}$ & $\begin{array}{c}\text { Percentage of } \\
\text { State } \\
\text { Population }\end{array}$ & $\begin{array}{l}\text { Percentage } \\
\text { Under } 18 \\
\text { (Region } \\
\text { Population) }\end{array}$ & $\begin{array}{l}\text { Percentage } \\
\text { At Least } \\
\text { High School } \\
\text { Diploma } \\
\text { (Region } \\
\text { Population) }\end{array}$ & $\begin{array}{l}\text { Median } \\
\text { Family } \\
\text { Income } \\
\text { (Region } \\
\text { Population) }\end{array}$ \\
\hline KIPDA Jefferson & 523 & 18.5 & 18 & 19.4 & 74.1 & $\$ 54,700$ \\
\hline Bluegrass Rural & 377 & 13.3 & 11 & 21.4 & 62.2 & $\$ 47,106$ \\
\hline Northern Kentucky & 277 & 9.8 & 10 & 19.1 & 64.8 & $\$ 52,825$ \\
\hline $\begin{array}{l}\text { Cumberland } \\
\text { Valley }\end{array}$ & 190 & 6.7 & 6 & 38.5 & 46.3 & $\$ 26,038$ \\
\hline Green River & 178 & 6.3 & 5 & 20.2 & 64.4 & $\$ 42,414$ \\
\hline Barren River & 172 & 6.1 & 6 & 25.8 & 52.6 & $\$ 37,970$ \\
\hline Lincoln Trail & 168 & 5.9 & 6 & 21.1 & 62.2 & $\$ 40,563$ \\
\hline Lake Cumberland & 145 & 5.1 & 5 & 47.0 & 47.1 & $\$ 31,400$ \\
\hline $\begin{array}{l}\text { Gateway/Buffalo } \\
\text { Trace }\end{array}$ & 131 & 4.6 & 3 & 31.0 & 55.7 & $\$ 33,520$ \\
\hline Pennyrile & 126 & 4.5 & 5 & 24.2 & 60.5 & $\$ 40,889$ \\
\hline Bluegrass Fayette & 122 & 4.3 & 6 & 16.9 & 80.2 & $\$ 55,200$ \\
\hline Kentucky River & 105 & 3.7 & 3 & 41.6 & 43.5 & $\$ 23,525$ \\
\hline Fivco & 93 & 3.3 & 3 & 32.1 & 55.1 & $\$ 32,840$ \\
\hline Big Sandy & 90 & 3.2 & 4 & 36.7 & 47.7 & $\$ 26,480$ \\
\hline KIPDA Rural & 72 & 2.5 & 4 & 16.0 & 65.8 & $\$ 49,717$ \\
\hline Purchase & 60 & 2.1 & 5 & 23.3 & 63.7 & $\$ 40,275$ \\
\hline Total & 2,898 & 100.0 & 100 & & & \\
\hline
\end{tabular}


median income for families in Kentucky is also found in these four regions (U.S. Census, 2000).

According to the 2000 U.S. Census, more than 1 in 5 children in Kentucky live in poverty and 1 in 2 live in families with incomes below $200 \%$ of the poverty level. In November 2001, Kentucky Youth Advocates developed a standard for measuring self-sufficiency. According to that standard a family of 3 requires an income approximately $200 \%$ of the federal poverty threshold to live without any government, family, or non-profit support (Graycarek \& Hoye, 2002). The federal poverty rate in 2000 was $\$ 13,900$. Therefore, a three-person family with less than $\$ 27,800$ would probably require financial assistance through food stamps, childcare subsidy, or health care benefits. In the regions of Big Sandy, Cumberland Valley, and Kentucky River, the median family income places a three-person family below the $200 \%$ poverty rate (Table 4). Overall, the 2000 U.S. census found that $20.8 \%$ of the children in Kentucky live below the $100 \%$ poverty rate and $24.8 \%$ live below the $200 \%$ rate (U.S. Census, 2000 ).

The Annie E. Casey Foundation considers children living with three or more of the following characteristics to be at high risk: (a) child lives in a family with income below the poverty line, (b) child lives in a single parent family, (c) child lives in a family where no parent has full time, year round employment, and (d) child lives with a household head who is a high school dropout. By this standard, $15 \%$ of the children in Kentucky are considered to be at high risk for maltreatment or neglect (Kentucky Kids Count Data Book, 2002).

As would be expected in light of Kentucky demographics, neglect was the 
primary program at time of case closure in $35 \%$ of the study cases (Figure 2) (Notice, however, that Figure 2 goes only to $50 \%$ ). Physical abuse and placement were the next most frequently identified primary programs of service at case closure. Placement as a program of service indicates that a least one child in the family was placed out of the home. In cases with more than one program of service the worker designates which program should be considered primary. However, when a child enters out-of-home care, the placement program supersedes other identified program areas in the case.

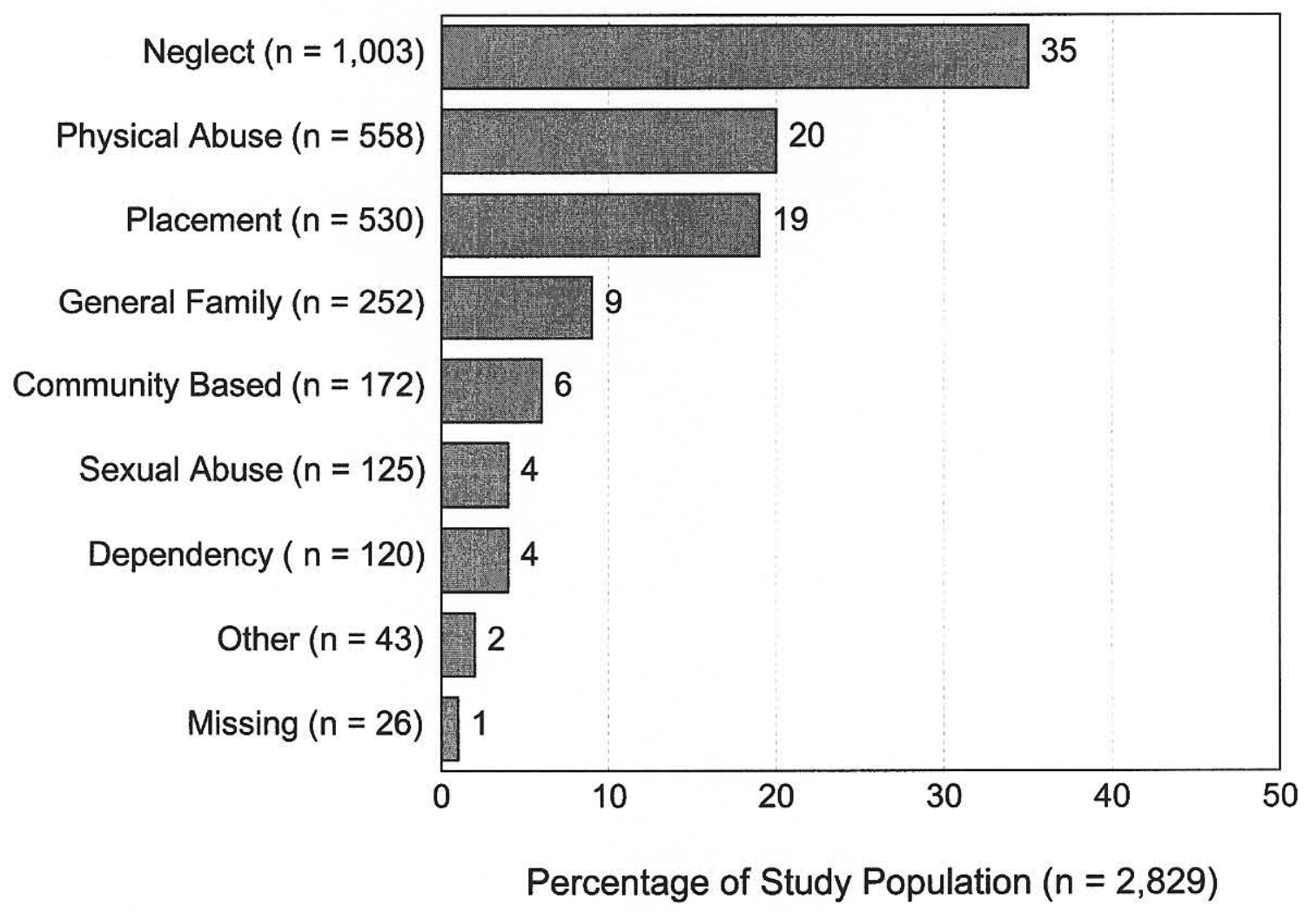

Figure 2. Primary service program at case closure. 
Building on Kentucky and study population demographics, the overarching question of this study was, What is the relationship between child protective services provided by the Kentucky Department of Protection and Permanency and risk of maltreatment? A flow chart (Figure 3 ) is provided to assist the reader in understanding Kentucky's referral and service delivery process. The interaction of independent variables upon risk assessment and recurrence are also highlighted (a) as a reference for the reader throughout the reporting of the findings, and (b) as a reminder that decision making in child protective service cases is a complex and challenging endeavor. Data analysis and findings are presented under three broad categories: (a) Change (research question 1), (b) Repeat Maltreatment (research questions 2 \& 3) and (c) Case Manager Demographics (research questions 4 \& 5).

\section{Change: Research Question 1}

Research Question 1: What are the relationships of change from the level of risk measured by the first Continuous Quality Assessment (CQA) at case opening to the level of risk measured by the last CQA at case closure?

\section{Examination of CQA Tool}

Huebner, researcher for the Commonwealth of Kentucky, analyzed CQAs $(n=479)$, completed between December 1999 and March 2002. Factor analysis using a verimax rotation, identified two factors: (a) safety (maltreatment, sequence of events, and adult patterns of behavior), and (b) well being (family stages of development, choice of discipline, child/youth development, and 


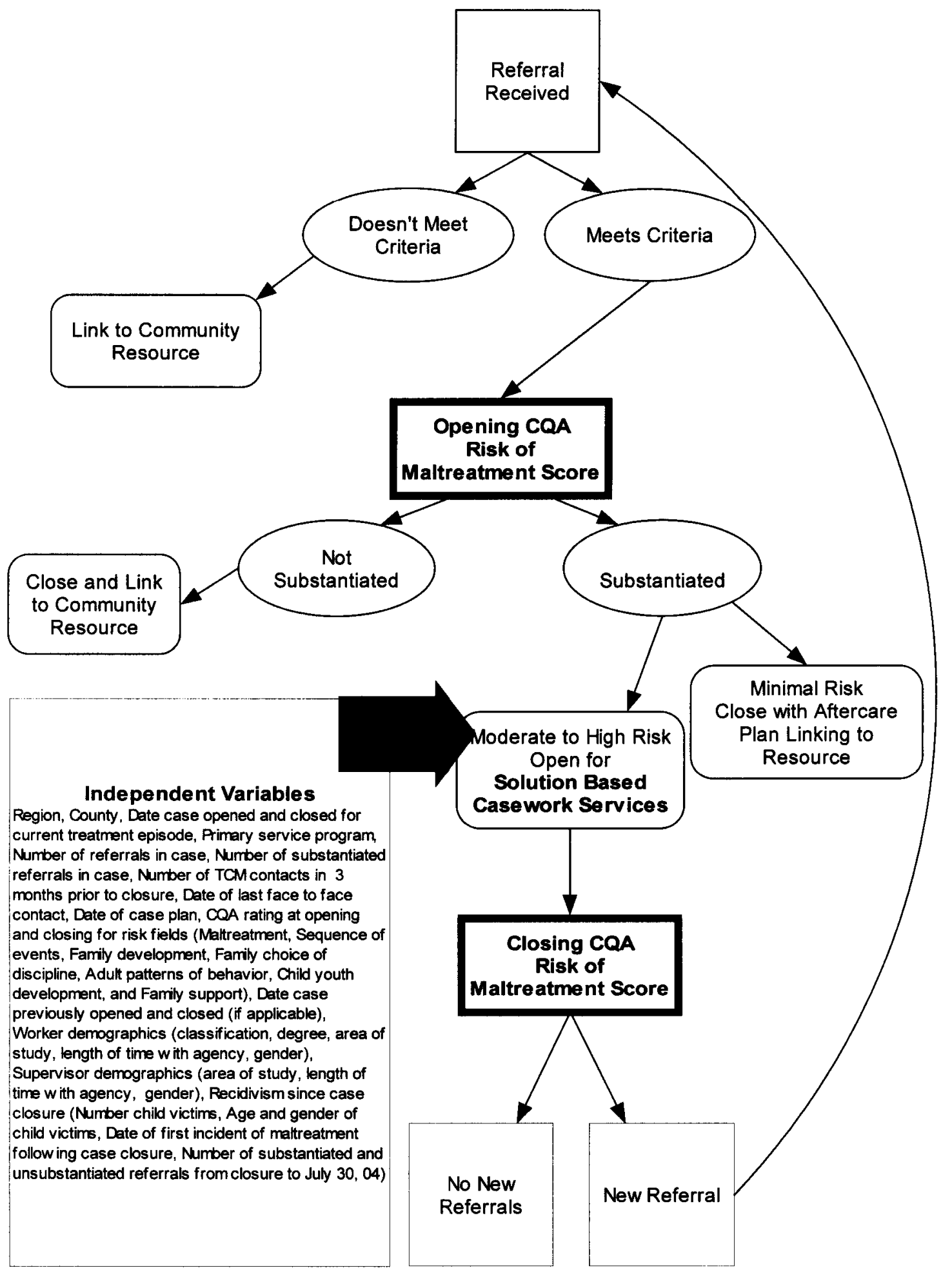

Figure 3. Flow chart of referral and service delivery process with independent

variables that are examined for relationship to overarching research question. 
family support). Conducting reliability analysis on the overall CQA and the identified factors she found the alpha coefficients of internal consistency to be (a) overall .79 , (b) safety risk factor .86 , and (c) well being risk factor .53 (Huebner, 2002).

Following Huebner's recommendation that future analyses consider these findings, an analysis was repeated on current data. Alpha coefficients of internal consistency for opening CQAs were (a) overall .76, (b) Huebner safety risk factor .81 , and (c) Huebner well being risk factor .63. Alpha coefficients of internal consistency for closing CQAs were (a) overall .78, (b) Huebner safety risk factor .67 , and (c) Huebner well being factor .63 .

A verimax rotation identified slightly different factors (current data base $n=$ $2,829)$ (the different factors will be labeled by researchers' names). Huebner's safety factor included the CQA risk domains of maltreatment, adult patterns of behavior, and sequence of events. Mudd's safety factor contained the same risk domains with the addition of family development (Table 5). Huebner's well being factor contained family development, choice of discipline, child/youth development, and family support. Mudd's well being factor contained the same risk domains with the omission of family development. Mudd's factor analysis yielded a Kaiser-Meyer-Olkin measure of sampling adequacy of .785, surpassing the .50 expected measure for a satisfactory factor analysis to proceed (Kinnear \& Gray, 1997). The Bartlett test of sphericity was significant at .000 . Reliability analysis, found Alpha coefficients of internal consistency to be (a) Mudd's overall 
Table 5

Differences Between Huebner's (2002) and Mudd's (2004) Factor Analyses of Risk Factors

\section{Safety Factor}

\begin{tabular}{lcc}
\hline Researcher & Huebner (2002) & Mudd (2004) \\
$\begin{array}{l}\text { Opening CQA Alpha } \\
\text { Coefficient }\end{array}$ & .81 & .85 \\
$\begin{array}{l}\text { Closing CQA Alpha } \\
\text { Coefficient }\end{array}$ & .67 & .78 \\
\hline Risk Domains & Maltreatment & Maltreatment \\
& Sequence of Events & Sequence of Events \\
& Adult Patterns of & Adult Patterns of \\
& Behavior & Behavior \\
& & Family Development
\end{tabular}

\section{Well Being Factor}

\begin{tabular}{lcc}
\hline Researcher & Huebner (2002) & Mudd (2004) \\
$\begin{array}{l}\text { Opening CQA Alpha } \\
\text { Coefficient }\end{array}$ & .53 & .43 \\
$\begin{array}{l}\text { Closing CQA Alpha } \\
\text { Coefficient }\end{array}$ & .63 & .53 \\
\hline Risk Domains & Family Development & Choice of Discipline \\
& Choice of Discipline & Child/Youth Development \\
& Child/Youth Development & Family Support \\
& Family Support &
\end{tabular}

\section{Overall CQA of All Risk Domains}

\begin{tabular}{lcc}
\hline Researcher & Huebner (2002) & Mudd (2004) \\
Opening Alpha Coefficient & .76 & .79 \\
Closing Alpha Coefficient & .76 & .79 \\
\hline
\end{tabular}


.76 (when the risk field of child development was removed this rose to .80$)$, (b)

Mudd's safety risk factor .85 , and (c) Mudd well being risk factor .43 . Thus, Mudd's safety risk factor has an internal alpha coefficiency value higher than Huebner's safety risk factor. Note also that the removal of child development from the overall rating increased the overall internal alpha efficiency value of the CQA. For analysis of change, Huebner and Mudd's safety factors will be considered. Mudd's well being risk factor will not be utilized due to its low alpha coeffiecient of internal consistency.

\section{Scoring of Opening and Closing CQAs}

Huebner (2002) found (a) $9.4 \%$ of children rated higher at closing than opening (including those with a ' 0 ' risk rating at opening), (b) incomplete scoring of the CQA, and (c) a high number of ' $O$ ' ratings for individual risk fields. Keep in mind that the CQA is scored by assigning a 0 to 4 rating in each of 7 risk domains (higher scores indicate higher risk). Thus, a risk rating higher at closing than at opening would indicate the level of risk had increased during the episode of treatment. However, Huebner (2002) cautioned that the differences in ratings might also be accounted for by an inconsistency in ratings. Huebner (2002) did find the CQA to be sensitive to severity of abuse. Huebner suggested that the low ratings of initial CQAs might be indicative of an incident-focused assessment, rather than the more desired comprehensive assessment.

Examination of these issues in the current database revealed that $6.3 \%$ of cases had higher ratings at closing than opening. Recall that cases with a '0' CQA cumulative score at opening were excluded from this study. The problem of 
incomplete scoring did not appear to be an issue. There were no cases with missing data on the opening or closing risk fields of maltreatment or sequence of events. A review of the other risk fields at opening and closing revealed no risk field having more than $9 \%$ missing data (NA was coded as missing). In cases with a nonfamilial perpetrator only the maltreatment and sequences risk fields of the CQA were completed. Thus, nonfamilial perpetrators accounted for a portion of the missing data.

High numbers of individual risk fields being scored '0' (no risk) was an issue, with family support (49.7\%), choice of discipline (41.9\%), and child/development (35.2\%) having the highest number of ' 0 ' ratings at opening (Table 6). The scores of maltreatment, sequence of events, adult behaviors, and family development were much more evenly dispersed from low to extreme.

At closing, from $43.5 \%$ to $84.9 \%$ of all risk fields were rated as ' 0 ' (Table 7). The highest number of ' 0 ' ratings was in maltreatment, however, scoring directions for the CQA directs that maltreatment should be scored ' 0 ' if there have been no new incidents of maltreatment in the last 6 months (this does not apply to the other risk fields), thus the ratings of " 0 " would indicate no new maltreatment in the last 6 months. Nearly $93 \%$ of the scores indicated that lack of positive family support was no, or only a mild, issue in the family. This figure would appear to be uncharacteristically high in light of the high number of neglectfully families in the study $(35 \%)$.

A comparison of risk levels at opening by Huebner safety factor, Mudd safety factor, and Huebner well being factor shows that low ratings were more 
Table 6

Crosstabulation of Risk at Case Opening by Risk Fields* $(n=2,829)$

\begin{tabular}{|c|c|c|c|c|c|c|}
\hline CQA Risk Field & \multicolumn{6}{|c|}{ Classification of Risk at Case Opening } \\
\hline Maltreatment & $\begin{array}{l}\text { None } \\
(0) \\
617 \\
21.8 \%\end{array}$ & $\begin{array}{c}\text { Mild } \\
(1) \\
349 \\
12.3 \%\end{array}$ & $\begin{array}{c}\text { Moderate } \\
(2) \\
678 \\
24.0 \%\end{array}$ & $\begin{array}{c}\text { Severe } \\
(3) \\
674 \\
23.8 \%\end{array}$ & $\begin{array}{c}\text { Extreme } \\
(4) \\
511 \\
18.1 \%\end{array}$ & Missing \\
\hline Sequence of Events & $\begin{array}{r}412 \\
14.6 \%\end{array}$ & $\begin{array}{r}452 \\
16.0 \%\end{array}$ & $\begin{array}{r}888 \\
31.4 \%\end{array}$ & $\begin{array}{r}746 \\
26.4 \%\end{array}$ & $\begin{array}{r}331 \\
11.7 \%\end{array}$ & \\
\hline $\begin{array}{l}\text { Adult Patterns of } \\
\text { Behavior }\end{array}$ & $\begin{array}{r}298 \\
10.5 \%\end{array}$ & $\begin{array}{r}552 \\
19.5 \%\end{array}$ & $\begin{array}{r}659 \\
23.3 \%\end{array}$ & $\begin{array}{r}507 \\
17.9 \%\end{array}$ & $\begin{array}{r}707 \\
25 \%\end{array}$ & $\begin{array}{r}106 \\
3.7 \%\end{array}$ \\
\hline $\begin{array}{l}\text { Family Development } \\
\text { Stages }\end{array}$ & $\begin{array}{r}361 \\
12.8 \%\end{array}$ & $\begin{array}{r}784 \\
27.7 \%\end{array}$ & $\begin{array}{r}630 \\
22.3 \%\end{array}$ & $\begin{array}{r}517 \\
18.3 \%\end{array}$ & $\begin{array}{r}410 \\
14.5 \%\end{array}$ & $\begin{array}{r}127 \\
4.5 \%\end{array}$ \\
\hline $\begin{array}{l}\text { Family Choice of } \\
\text { Discipline }\end{array}$ & $\begin{array}{r}1,184 \\
41.9 \%\end{array}$ & $\begin{array}{r}592 \\
20.9 \%\end{array}$ & $\begin{array}{r}417 \\
14.7 \%\end{array}$ & $\begin{array}{r}246 \\
8.7 \%\end{array}$ & $\begin{array}{r}156 \\
5.5 \%\end{array}$ & $\begin{array}{r}234 \\
8.3 \%\end{array}$ \\
\hline $\begin{array}{l}\text { Child/Youth } \\
\text { Development }\end{array}$ & $\begin{array}{r}997 \\
35.2 \%\end{array}$ & $\begin{array}{r}686 \\
24.2 \%\end{array}$ & $\begin{array}{r}522 \\
18.5 \%\end{array}$ & $\begin{array}{r}363 \\
12.8 \%\end{array}$ & $\begin{array}{r}165 \\
5.8 \%\end{array}$ & $\begin{array}{r}96 \\
3.4 \%\end{array}$ \\
\hline Family Support & $\begin{array}{r}1,406 \\
49.7 \%\end{array}$ & $\begin{array}{r}673 \\
23.8 \%\end{array}$ & $\begin{array}{r}476 \\
16.8 \%\end{array}$ & $\begin{array}{r}128 \\
4.5 \%\end{array}$ & $\begin{array}{r}72 \\
2.5 \%\end{array}$ & $\begin{array}{r}74 \\
2.6 \%\end{array}$ \\
\hline
\end{tabular}

apparent in the risk fields associated with well being (Table 8). The well-being (family development, discipline, child/youth, and family youth) factor indicates that over $83 \%$ of the scores were rated no risk, mild risk, or moderate risk. Remember that reliability analysis found the well being risk factor to be below acceptable limits for internal consistency. At case closing only $1.7 \%$ of cases were rated as having significant or high ratings in well being (Table 9). Based on low ratings and less than acceptable internal consistency, the well being factor was not considered as a valid measure for this study. Visual display of data between opening and closing safety risk factors shows the Mudd factor to have 
Table 7

Crosstabulation of Risk at Case Closure by Risk Fields* $(n=2,829)$

\begin{tabular}{|c|c|c|c|c|c|c|}
\hline CQA Risk Field & \multicolumn{6}{|c|}{ Classification of Risk at Case Closure } \\
\hline Maltreatment & $\begin{array}{c}\text { None } \\
(0) \\
2,403 \\
84.9 \%\end{array}$ & $\begin{array}{l}\text { Mild } \\
\text { (1) } \\
232 \\
8.2 \%\end{array}$ & $\begin{array}{c}\text { Moderate } \\
\text { (2) } \\
94 \\
3.3 \%\end{array}$ & $\begin{array}{c}\text { Severe } \\
\text { (3) } \\
61 \\
2.2 \%\end{array}$ & $\begin{array}{c}\text { Extreme } \\
\text { (4) } \\
39 \\
1.4 \%\end{array}$ & Missing \\
\hline Sequence of Events & $\begin{array}{r}2,072 \\
73.2 \%\end{array}$ & $\begin{array}{r}414 \\
14.6 \%\end{array}$ & $\begin{array}{r}229 \\
8.1 \%\end{array}$ & $\begin{array}{r}87 \\
3.1 \%\end{array}$ & $\begin{array}{r}27 \\
1.0 \%\end{array}$ & \\
\hline $\begin{array}{l}\text { Adult Patterns of } \\
\text { Behavior }\end{array}$ & $\begin{array}{r}1,231 \\
43.5 \%\end{array}$ & $\begin{array}{r}799 \\
28.2 \%\end{array}$ & $\begin{array}{r}297 \\
10.5 \%\end{array}$ & $\begin{array}{r}127 \\
4.5 \%\end{array}$ & $\begin{array}{r}196 \\
6.9 \%\end{array}$ & $\begin{array}{r}179 \\
6.3 \%\end{array}$ \\
\hline $\begin{array}{l}\text { Family Development } \\
\text { Stages }\end{array}$ & $\begin{array}{r}1,463 \\
51.7 \%\end{array}$ & $\begin{array}{r}718 \\
25.4 \%\end{array}$ & $\begin{array}{r}224 \\
7.9 \%\end{array}$ & $\begin{array}{r}120 \\
4.2 \%\end{array}$ & $\begin{array}{r}108 \\
3.8 \%\end{array}$ & $\begin{array}{r}196 \\
6.9 \%\end{array}$ \\
\hline $\begin{array}{l}\text { Family Choice of } \\
\text { Discipline }\end{array}$ & $\begin{array}{r}1,930 \\
68.2 \%\end{array}$ & $\begin{array}{r}481 \\
17 \%\end{array}$ & $\begin{array}{r}103 \\
3.6 \%\end{array}$ & $\begin{array}{r}38 \\
1.3 \%\end{array}$ & $\begin{array}{r}31 \\
1.1 \%\end{array}$ & $\begin{array}{r}246 \\
8.7 \%\end{array}$ \\
\hline $\begin{array}{l}\text { Child/Youth } \\
\text { Development }\end{array}$ & $\begin{array}{r}1,554 \\
54.9 \%\end{array}$ & $\begin{array}{r}656 \\
23.2 \%\end{array}$ & $\begin{array}{r}254 \\
9.0 \%\end{array}$ & $\begin{array}{r}119 \\
4.2 \%\end{array}$ & $\begin{array}{r}60 \\
2.1 \%\end{array}$ & $\begin{array}{r}186 \\
6.6 \%\end{array}$ \\
\hline Family Support & $\begin{array}{r}2,197 \\
77.7 \%\end{array}$ & $\begin{array}{r}431 \\
15.2 \%\end{array}$ & $\begin{array}{r}116 \\
4.1 \%\end{array}$ & $\begin{array}{r}38 \\
1.3 \%\end{array}$ & $\begin{array}{r}27 \\
1.0 \%\end{array}$ & $\begin{array}{r}20 \\
.7 \%\end{array}$ \\
\hline
\end{tabular}

Count and percentage of region population with risk fields at closing CQA

slightly higher scores at closing than the Huebner Factor (Figures $4 \& 5$, and note that these figures end at $50 \%$ ).

\section{Tests of Significance for Change Between Opening and Closing}

Paired t-testing, comparing changes in opening and closing CQA scores by Huebner safety risk factor, Mudd safety risk factor, and by cumulative scores, found significant differences $(p<.001)$ in level of risk (Table 10). The Huebner safety risk factor includes the CQA risk fields of maltreatment, sequence of events, and adult patterns of behavior. The Mudd safety risk factor includes the CQA risk fields of maltreatment, sequence of events, adult patterns of behavior, 
Table 8

Crosstabulation of Risk at Case Opening by Huebner Safety Factor, Mudd Safety Factor and Huebner Well Being Factor $(n=2,829)$

\begin{tabular}{|c|c|c|c|c|c|c|}
\hline \multicolumn{2}{|c|}{ CQA Risk Factors } & \multicolumn{5}{|c|}{ Classification of Risk at Case Opening } \\
\hline $\begin{array}{l}\text { Safety Factor } \\
\text { Ratings }\end{array}$ & $\begin{array}{r}\text { None } \\
0\end{array}$ & $\begin{array}{l}\text { Low } \\
(1-3)\end{array}$ & $\begin{array}{r}\text { Moderate } \\
(4-6)\end{array}$ & $\begin{array}{r}\text { Significant } \\
(7-9)\end{array}$ & $\begin{array}{r}\text { High } \\
(10-12)\end{array}$ & Missing \\
\hline $\begin{array}{l}\text { Huebner Safety } \\
\text { Scores* }\end{array}$ & $\begin{array}{r}118 \\
4.2 \%\end{array}$ & $\begin{array}{r}482 \\
17 \%\end{array}$ & $\begin{array}{r}759 \\
26.8 \%\end{array}$ & $\begin{array}{r}794 \\
28.1 \%\end{array}$ & $\begin{array}{r}570 \\
20.1\end{array}$ & $\begin{array}{r}106 \\
3.7 \%\end{array}$ \\
\hline $\begin{array}{l}\text { Safety Factor } \\
\text { Ratings }\end{array}$ & 0 & $\begin{array}{l}\text { Low } \\
(1-4)\end{array}$ & $\begin{array}{r}\text { Moderate } \\
(5-8)\end{array}$ & $\begin{array}{r}\text { Significant } \\
(9-12)\end{array}$ & $\begin{array}{r}\text { High } \\
(13-16)\end{array}$ & Missing \\
\hline $\begin{array}{l}\text { Mudd Safety } \\
\text { Scores }{ }^{\star}\end{array}$ & $\begin{array}{r}71 \\
2.5 \%\end{array}$ & $\begin{array}{r}508 \\
18 \%\end{array}$ & $\begin{array}{r}799 \\
28.2 \%\end{array}$ & $\begin{array}{r}777 \\
27.5 \%\end{array}$ & $\begin{array}{l}526 \\
18.6\end{array}$ & $\begin{array}{r}148 \\
5.2 \%\end{array}$ \\
\hline $\begin{array}{l}\text { Well Being } \\
\text { Factor Ratings }\end{array}$ & $\overline{0}$ & $\begin{array}{l}\text { Low } \\
(1-4)\end{array}$ & $\begin{array}{r}\text { Moderate } \\
(5-8)\end{array}$ & $\begin{array}{r}\text { Significant } \\
(9-12)\end{array}$ & $\begin{array}{r}\text { High } \\
(13-16)\end{array}$ & Missing \\
\hline $\begin{array}{l}\text { Huebner Well } \\
\text { Being Factor }\end{array}$ & $\begin{array}{c}101 \\
3.6 \%\end{array}$ & $\begin{array}{r}1,269 \\
44.9 \% \\
\end{array}$ & $\begin{array}{r}988 \\
34.9 \\
\end{array}$ & $\begin{array}{r}358 \\
12.7 \%\end{array}$ & $\begin{array}{r}39 \\
1.4 \%\end{array}$ & $\begin{array}{r}74 \\
2.6\end{array}$ \\
\hline
\end{tabular}

Count and percentage of region population with closing cumulative CQA score

and family development stages and tasks. The cumulative score would be the same whether considering the Mudd safety factor or Huebner safety factor since the cumulative score includes all 7 risk domains. The safety factors and cumulative scores were significantly lower at closing than at opening indicating a reduction in assessed level of risk.

The Pearson product-moment correlation ( $r$ ) with an alpha set at .001 was used to determine strength and direction of relationships between CQA risk factors and change in CQA score between the opening and closing (Table 11). The correlations between risk factors and change were found to be statistically significant $(p<.001)$. The coefficients of determination $\left(r^{2}\right)$ were examined to determine measures of association between risk factors and CQA change 


\section{Table 9}

\section{Crosstabulation of Risk at Case Closure by Huebner Safety Factor, Mudd}

Safety Factor and Huebner Well Being Factor $(n=2,829)$

\begin{tabular}{|c|c|c|c|c|c|c|}
\hline \multicolumn{2}{|c|}{ CQA Risk Factors } & \multicolumn{5}{|c|}{ Classification of Risk at Case Closing } \\
\hline $\begin{array}{l}\text { Safety Factor } \\
\text { Ratings }\end{array}$ & $\begin{array}{r}\text { None } \\
0\end{array}$ & $\begin{array}{l}\text { Low } \\
(1-3)\end{array}$ & $\begin{array}{r}\text { Moderate } \\
(4-6)\end{array}$ & $\begin{array}{r}\text { Significant } \\
(7-9)\end{array}$ & $\begin{array}{r}\text { High } \\
(10-12)\end{array}$ & Missing \\
\hline $\begin{array}{l}\text { Huebner Safety } \\
\text { Scores* }\end{array}$ & $\begin{array}{r}1,040 \\
36.8 \%\end{array}$ & $\begin{array}{r}1,175 \\
41.5 \%\end{array}$ & $\begin{array}{r}307 \\
10.9 \%\end{array}$ & $\begin{array}{r}89 \\
3.1 \%\end{array}$ & $\begin{array}{r}39 \\
1.4\end{array}$ & $\begin{array}{r}179 \\
6.3 \%\end{array}$ \\
\hline Safety Factor & $\begin{array}{c}0 \\
\text { Ratings }\end{array}$ & $\begin{array}{l}\text { Low } \\
(1-4)\end{array}$ & $\begin{array}{r}\text { Moderate } \\
(5-8)\end{array}$ & $\begin{array}{r}\text { Significant } \\
(9-12)\end{array}$ & $\begin{array}{r}\text { High } \\
(13-16)\end{array}$ & Missing \\
\hline $\begin{array}{l}\text { Mudd Safety } \\
\text { Scores }{ }^{*}\end{array}$ & $\begin{array}{r}931 \\
32.9 \%\end{array}$ & $\begin{array}{r}1,226 \\
43.3 \%\end{array}$ & $\begin{array}{r}311 \\
11 \%\end{array}$ & $\begin{array}{r}35 \\
1.2 \%\end{array}$ & $\begin{array}{r}81 \\
2.9\end{array}$ & $\begin{array}{r}245 \\
8.7 \%\end{array}$ \\
\hline $\begin{array}{l}\text { Well Being } \\
\text { Fac }\end{array}$ & $\begin{array}{r}0 \\
\text { Ratings }\end{array}$ & $\begin{array}{l}\text { Low } \\
(1-4)\end{array}$ & $\begin{array}{r}\text { Moderate } \\
(5-8)\end{array}$ & $\begin{array}{r}\text { Significant } \\
(9-12)\end{array}$ & $\begin{array}{r}\text { High } \\
(13-16)\end{array}$ & Missing \\
\hline $\begin{array}{l}\text { Huebner Well } \\
\text { Being Factor }\end{array}$ & $\begin{array}{r}101 \\
3.6 \% \\
\end{array}$ & $\begin{array}{r}2,453 \\
86.7 \%\end{array}$ & $\begin{array}{r}206 \\
7.3 \%\end{array}$ & $\begin{array}{r}38 \\
1.3 \% \\
\end{array}$ & $\begin{array}{r}11 \\
.4 \% \\
\end{array}$ & $\begin{array}{r}20 \\
.7\end{array}$ \\
\hline
\end{tabular}

Count and percentage of region population with closing cumulative CQA score

between opening and closing. The Mudd safety factor (.50) association with change was slightly stronger than the Huebner safety factor (.47). To accommodate the Person $r$, the 5-point risk ratings (Likert scales) were treated as interval data (Likert, 1932). The correlations between individual risk fields (maltreatment, sequence of events, family development, choice of discipline, adult behaviors, child development and family support) and change were also found to be statistically significant $(p<.001)$. The strongest associations were found in maltreatment, sequence of events, family development, and adult patterns of behavior. Although significant $(p<.001)$, the association between the opening CQA cumulative score and change (reduction in risk) was smaller than the associations between the safety scores and change. 


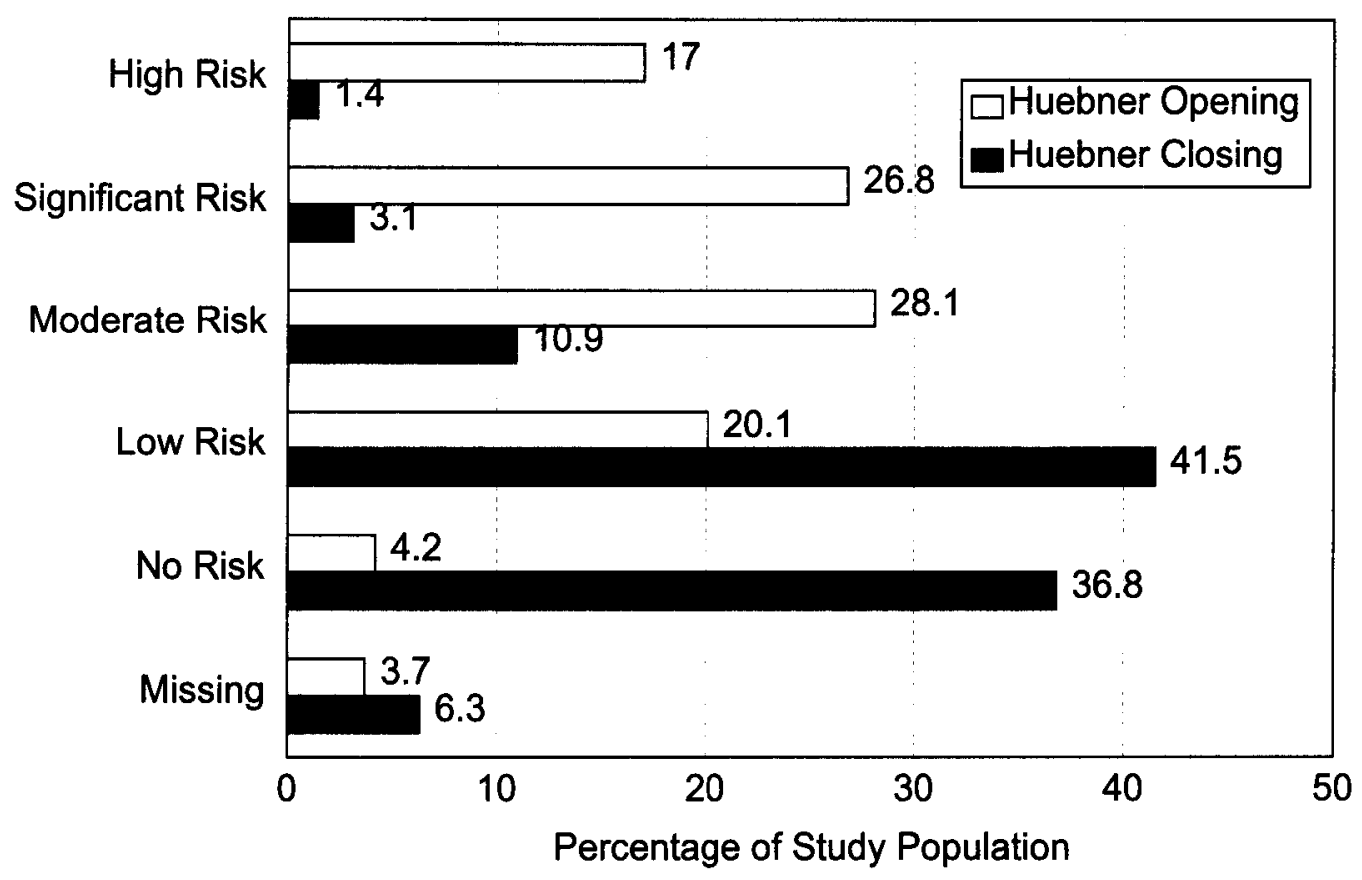

Figure 4. Comparison of Huebner's opening and closing Safety Risk Factor scores.

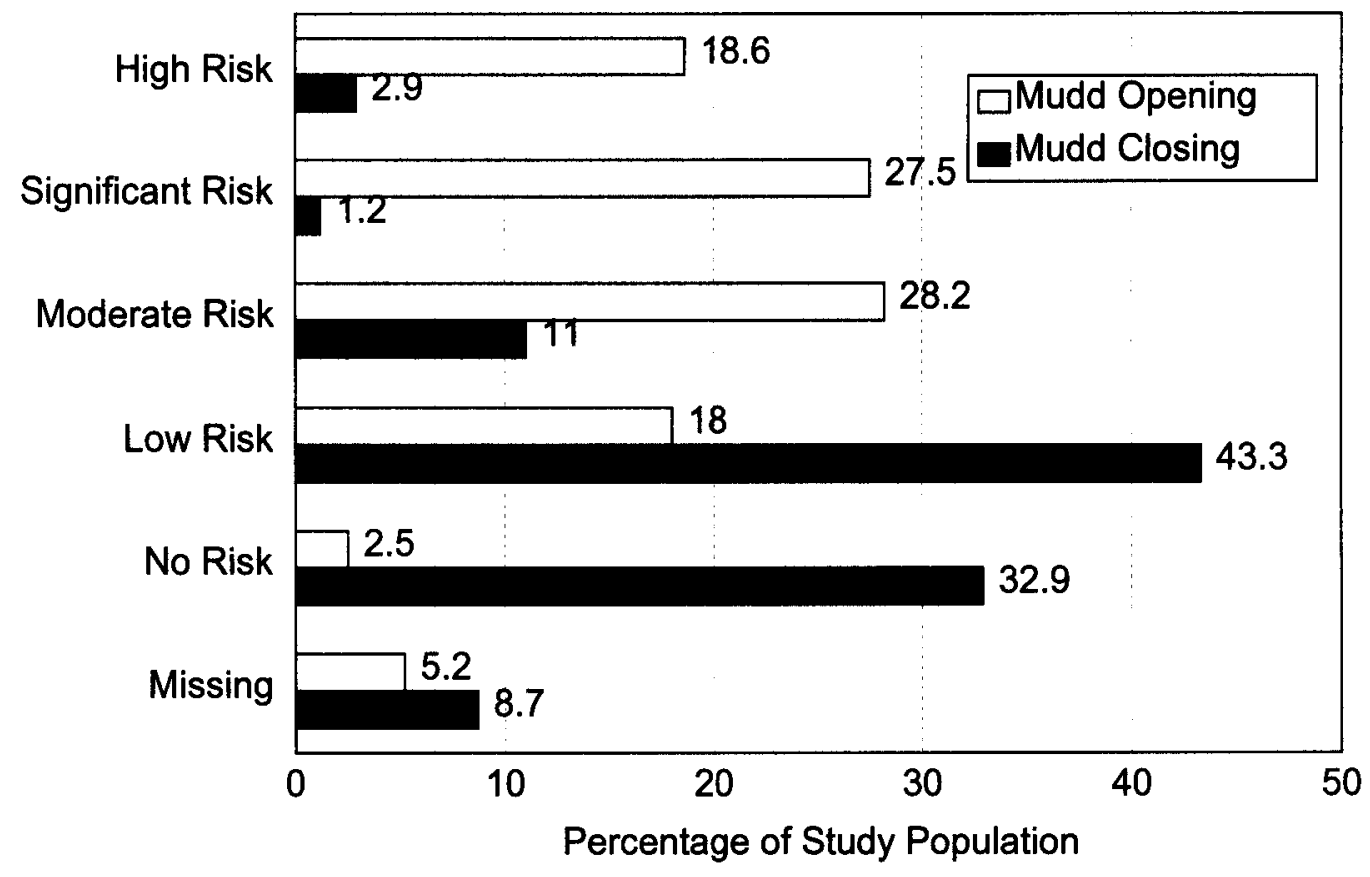

Figure 5. Comparison of Mudd's opening and closing Safety Risk Factor scores. 
Table 10

Paired t-test Analyses Comparing Changes In Risk Factors and Cumulative Scores Between Opening and Closing

\begin{tabular}{lcccccc}
\hline & $\begin{array}{c}\text { Mean } \\
\text { Opening } \\
\text { CQA }\end{array}$ & $\begin{array}{c}\text { Standard } \\
\text { Deviation }\end{array}$ & $\begin{array}{c}\text { Mean } \\
\text { Closing } \\
\text { CQA }\end{array}$ & $\begin{array}{c}\text { Standard } \\
\text { Deviation }\end{array}$ & $\begin{array}{c}\text { Number } \\
\text { of Cases }\end{array}$ & $\begin{array}{c}\text { Sig. } \\
\text { (2-tailed) }\end{array}$ \\
\hline $\begin{array}{l}\text { Huebner Safety Factor } \\
\text { (12 point scale) }\end{array}$ & 6.36 & 3.3 & 1.69 & 2.2 & 2,588 & .000 \\
$\begin{array}{l}\text { Mudd Safety Factor } \\
\text { (16 point scale) }\end{array}$ & 8.29 & 4.3 & 2.42 & 3 & 2,522 & .000 \\
$\begin{array}{l}\text { CQA Cumulative } \\
\begin{array}{l}\text { Score } \\
\text { (28 point scale) }\end{array}\end{array}$ & 11.20 & 5.5 & 3.71 & 4.2 & 2,465 & .000 \\
\hline Note. Higher CQA scores represent greater risk for maltreatment. & & & & & & \\
\hline
\end{tabular}

\section{Table 11}

\section{Correlations Between CQA Risk Factors and Change in CQA Score Between Opening and Closing CQA}

\begin{tabular}{lcccc}
\hline \multicolumn{1}{c}{ Risk Field } & $r$ & $r^{2}$ & $N$ & Sig. (2 tail) \\
\hline Huebner Safety Factor & .689 & .47 & 2,416 & .000 \\
Mudd Safety Factor & .710 & .50 & 2,392 & .000 \\
$\begin{array}{l}\text { CQA Cumulative Rating at } \\
\text { Opening }\end{array}$ & .329 & .11 & 2,465 & .000 \\
\hline
\end{tabular}

\section{Change in CQA by Program Area}

Emotional abuse had the greatest change in overall mean between opening and closing, closely followed by sexual abuse (Table 12) (the higher the mean of change, the greater the reduction in risk). Sexual abuse and emotional abuse also had the greatest opening CQA means (Table 13). The smallest changes in overall means were found in community based juvenile services and 
general family (Table 12). Not surprisingly these program areas also had the lowest opening CQA means (Table 13). Thus program areas rated highest at opening, had the most room for improvement. Although opening CQA means by program area ranged from 7.13 to 14.73 , there was only a 1.08 difference between the highest and lowest mean by program area on the closing CQA (Table 13).

Paired t-testing of the overall means of CQA scores at opening and closing by primary program areas revealed that the differences (reduction in risk) in all program areas were statistically significant $(p<.001)$ (Table 13). The

\section{Table 12}

Mean Frequency Scores for Change Between CQA Opening and Closing Scores by Primary Program Area

\begin{tabular}{|c|c|c|c|c|c|}
\hline Primary Program ${ }^{\star \star \star}$ & Mean & $\bar{N}$ & SD & Min.* & $\operatorname{Max}^{\star \star}$ \\
\hline Emotional Abuse & 10.43 & 30 & 6.7 & 0 & 20 \\
\hline Sexual Abuse & 10.34 & 116 & 6.3 & -7 & 23 \\
\hline Physical Abuse & 8.41 & 520 & 5.9 & -22 & 26 \\
\hline Neglect & 8.06 & 932 & 5.8 & -19 & 24 \\
\hline Placement & 7.52 & 364 & 7.2 & -15 & 24 \\
\hline Dependency & 6.27 & 98 & 5.6 & -7 & 22 \\
\hline Community Based Juvenile & 4.09 & 146 & 5.4 & -9 & 27 \\
\hline General Family & 3.80 & 228 & 5.4 & -22 & 19 \\
\hline
\end{tabular}


Table 13

Paired t-test Analysis Comparing Changes in Scores on CQA by Program

Area

\begin{tabular}{lcrrrrr}
\hline & $\begin{array}{c}\text { Mean } \\
\text { Opening } \\
\text { CQA }\end{array}$ & $\begin{array}{c}\text { Standard } \\
\text { Deviation }\end{array}$ & $\begin{array}{c}\text { Mean } \\
\text { Closing } \\
\text { CQA }\end{array}$ & $\begin{array}{c}\text { Standard } \\
\text { Deviation }\end{array}$ & $\begin{array}{c}\text { Number } \\
\text { of } \\
\text { Cases }\end{array}$ & $\begin{array}{c}\text { Sig. } \\
\text { (2-tailed) }\end{array}$ \\
\hline Sexual Abuse & 14.73 & 5.3 & 4.40 & 4.0 & 116 & .000 \\
Emotional Abuse & 13.87 & 5.2 & 3.43 & 3.7 & 30 & .000 \\
Physical Abuse & 12.13 & 5.1 & 3.72 & 3.8 & 520 & .000 \\
Placement & 11.92 & 6.1 & 4.40 & 4.8 & 364 & .000 \\
Neglect & 11.55 & 4.9 & 3.49 & 4.1 & 932 & .000 \\
Dependency & 9.58 & 5.3 & 3.32 & 3.7 & 98 & .000 \\
$\begin{array}{l}\text { Community Based } \\
\text { Juvenile Services }\end{array}$ & 7.67 & 4.9 & 3.58 & 4.0 & 146 & .000 \\
General Family & 7.13 & 4.6 & 3.33 & 4.1 & 228 & .000 \\
\hline
\end{tabular}

Note. Higher CQA scores represent greater risk for maltreatment.

overall mean of the length of time between opening and closing CQAs was 11.2 months, with a range of less than 1 month to 31 months. The mean for all program areas was within 2 months of the overall mean (11.2 months), except placement (14.65 months) and emotional abuse (8.7 months).

\section{Change by Region}

The highest means of change (reduction in risk) in CQA scores between opening and closing CQAs were found in the Fivco and Cumberland Valley regions in Eastern Kentucky. The smallest mean of change was found in the Bluegrass Fayette region in Central Kentucky. The overall mean of change in scores from opening to closing CQA was 7.48 points $(n=2,465)$ (Table 14). The mean for months of service between opening and closing of cases was 17.01 
months (Table 14). Shortest service times were found in the KIPDA Rural, Lake Cumberland, Lincoln Trail, and Cumberland Valley regions. Longer service times were found in the Green River, Bluegrass Rural, Bluegrass Fayette, and

Table 14

Frequency Scores in Means of Change and Months of Service Case Open for Current Treatment Episode

\begin{tabular}{|c|c|c|c|c|c|c|}
\hline Region $^{\star \star}$ & $\begin{array}{c}\text { Mean } \\
\text { Change }\end{array}$ & $\bar{N}$ & SD & $\begin{array}{c}\text { Mean } \\
\text { Months of } \\
\text { Service }\end{array}$ & $\bar{N}$ & $\overline{S D}$ \\
\hline Fivco & 10.45 & 83 & 6.3 & 17.02 & 93 & 16.2 \\
\hline Cumberland Valley & 9.93 & 167 & 6.5 & 14.07 & 190 & 14.2 \\
\hline KIPDA Rural & 8.41 & 63 & 6.6 & 13.74 & 72 & 9.8 \\
\hline Big Sandy & 8.04 & 77 & 6.5 & 19.29 & 90 & 16.1 \\
\hline Lake Cumberland & 7.90 & 126 & 6.3 & 13.70 & 145 & 12.9 \\
\hline Kentucky River & 7.69 & 100 & 6.9 & 17.63 & 105 & 14 \\
\hline KIPDA Jefferson & 7.50 & 453 & 5.4 & 14.9 & 523 & 13.7 \\
\hline Barren River & 7.36 & 157 & 6.3 & 14.96 & 172 & 11.7 \\
\hline Lincoln Trail & 7.15 & 149 & 5.5 & 14.28 & 168 & 12.5 \\
\hline Purchase & 7.02 & 51 & 5.6 & 20.39 & 60 & 15.4 \\
\hline Green River & 6.98 & 167 & 6.0 & 21.67 & 178 & 17.5 \\
\hline Gateway/Buffalo Trace & 6.96 & 111 & 6.0 & 18.31 & 131 & 15.8 \\
\hline Northern Kentucky & 6.88 & 236 & 6.7 & 17.04 & 277 & 14.4 \\
\hline Bluegrass Rural & 6.70 & 321 & 6.4 & 20.77 & 377 & 16.3 \\
\hline Pennyrile & 6.69 & 110 & 7.0 & 16.28 & 126 & 14.1 \\
\hline Bluegrass/Fayette & 6.18 & 94 & 6.8 & 20.08 & 122 & 16.2 \\
\hline Overall/Total & 7.48 & 2,465 & 6.3 & 17.01 & 2,829 & 14.0 \\
\hline
\end{tabular}

${ }^{\star \star}$ Oneway ANOVA Between groups $p<.001$ for change and months of service 
Purchase regions. Paired t-testing of the overall CQA scores at opening and closing by service region revealed that the differences (reduction in risk) in all regions were statistically significant $(p .<.001)$ (Table 15).

\section{Table 15}

\section{Paired t-test Analysis Comparing Changes in Scores on CQA by Region}

\begin{tabular}{|c|c|c|c|c|c|c|}
\hline & $\begin{array}{r}\text { Mean } \\
\text { Opening } \\
\text { CQA }\end{array}$ & $\begin{array}{l}\text { Standard } \\
\text { Deviation }\end{array}$ & $\begin{array}{r}\text { Mean } \\
\text { Closing } \\
\text { CQA }\end{array}$ & $\begin{array}{l}\text { Standard } \\
\text { Deviation }\end{array}$ & $\begin{array}{l}\text { Number } \\
\text { of Cases }\end{array}$ & $\begin{array}{r}\text { Sig. } \\
\text { (2-tailed) }\end{array}$ \\
\hline Cumberland Valley & 14.27 & 5.1 & 4.34 & 4.4 & 167 & .000 \\
\hline Fivco & 13.40 & 5.8 & 2.95 & 3.6 & 83 & .000 \\
\hline Purchase & 12.45 & 5.6 & 5.43 & 4.6 & 51 & .000 \\
\hline KIPDA Rural & 12.06 & 6.3 & 3.65 & 4.2 & 63 & .000 \\
\hline Lincoln Trail & 11.48 & 5.4 & 4.32 & 3.7 & 149 & .000 \\
\hline Kentucky River & 11.43 & 5.7 & 3.74 & 4.6 & 100 & .000 \\
\hline Northern Kentucky & 11.34 & 5.7 & 4.46 & 4.2 & 236 & .000 \\
\hline Big Sandy & 11.32 & 5.4 & 3.29 & 4.0 & 77 & .000 \\
\hline Pennyrile & 11.23 & 5.8 & 4.54 & 5.2 & 110 & .000 \\
\hline Lake Cumberland & 11.21 & 5.1 & 3.32 & 3.8 & 126 & .000 \\
\hline Barren River & 11.07 & 5.3 & 3.71 & 4.5 & 157 & .000 \\
\hline Bluegrass Fayette & 10.78 & 5.6 & 4.60 & 4.6 & 94 & .000 \\
\hline KIPDA Jefferson & 10.49 & 5.0 & 3.00 & 3.4 & 453 & .000 \\
\hline Bluegrass Rural & 10.24 & 5.3 & 3.95 & 4.6 & 344 & .000 \\
\hline $\begin{array}{l}\text { Gateway/Buffalo } \\
\text { Trace }\end{array}$ & 10.09 & 5.5 & 3.13 & 3.6 & 111 & .000 \\
\hline Green River & 9.80 & 5.2 & 2.83 & 3.2 & 167 & .000 \\
\hline
\end{tabular}


Cumberland Valley, KIPDA Rural, KIPDA Jefferson, and Lake

Cumberland regions had means of change above the overall State mean of change, while their means of months of service were below the overall state mean. Thus, they were able to accomplish higher reduction in risk in a less than average service time. Conversely, the Bluegrass Rural, Bluegrass Fayette, Purchase, Green River, and Gateway Buffalo Trace regions had less than average means of change, while their service times were higher than the State's overall mean (Table 14). Hence, it took them longer to accomplish less than an average reduction in risk.

The mean length of time between opening and closing CQAs was 11.2 months $(N=2,829)$. A frequency of time between opening and closing CQAs revealed that $52 \%$ of the cases were open for 9 months or less. Cases open for 1 month or less $(9.3 \%)$ were generally investigations that took longer than 45 days to complete. They were not open for service beyond the investigation. Only $6.2 \%$ of the cases were open for more than 24 months.

The mean number of months from date of case opening to date of case closing was 17.01 months, while the mean from the first CQA to the last CQA was 11.2 months $(N=2,829)$. Time lapse between case opening and completion of the first CQA accounted for the majority of the difference. Sixty percent of the opening CQAs were completed within 60 days of case opening; however, $12 \%$ had from 2 to 5 years difference in case opening and completion of the CQA. One explanation for this delay was that many of these cases were opened prior to the development of the CQA. Time lapse between completion of the last CQA 
and case closure was an issue in only $10 \%$ of the study cases. Eighty-nine percent of the study cases were closed within 30 days of the last CQA being completed, with another $5 \%$ being closed within 60 days. Only $6 \%$ of the cases were not closed within 60 days of the final CQA being completed. Placement program cases were open nearly three times longer than emotional abuse and general family programs.

A cross tabulation of regions by cumulative closing CQA scores revealed that there were differences in level of risk assessed at the time of case closure between the regions (Table 16). The Green River region assessed $92 \%$ of their cases as low risk at case closure, while the Purchase region assessed only $65 \%$ of their cases as being low risk at time of closure. The Big Sandy, Bluegrass Fayette, Cumberland Valley, Pennyrile and Purchase regions rated over $5 \%$ of their cases as being significant or high risk at case closure. While the KIPDA Jefferson (1.3\%) and Fivco (1.2\%) regions rated just slightly more than $1 \%$ of their cases as being significant or high risk at closure. Overall, $82.5 \%$ of the cases were rated as low risk at closure. Only $.9 \%$ of the cases were rated as high risk at case closure. Closing CQAs were missing in $364(12 . \%)$ of the cases.

A cross tabulation of cases, geographic classification of region (urban, Appalachia, and rural areas) (Table 17) by cumulative closing CQA scores, revealed that there was no significant difference in level of risk assessed at the time of case closure between the geographic classification of regions. A cross tabulation of geographically classified region by change in cumulative CQA 
Table 16

Crosstabulation of Closing Cumulative CQA Scores by Region*

\begin{tabular}{|c|c|c|c|c|c|}
\hline \multirow{2}{*}{$\begin{array}{c}\text { Region/Geographic } \\
\text { Classification }\end{array}$} & \multicolumn{5}{|c|}{ Classification of Risk at Case Closure } \\
\hline & $\begin{array}{c}\text { Low } \\
\text { Risk } \\
(0-6.9)\end{array}$ & $\begin{array}{c}\text { Moderate } \\
\text { Risk } \\
(7-13.9)\end{array}$ & $\begin{array}{c}\text { Significant } \\
\text { Risk } \\
(14-19.9)\end{array}$ & $\begin{array}{c}\text { High } \\
\text { Risk } \\
(20-28)\end{array}$ & Total \\
\hline $\begin{array}{l}\text { Barren River } \\
\text { Rural }\end{array}$ & $\begin{array}{r}128 \\
81.5 \%\end{array}$ & $\begin{array}{r}24 \\
15.3 \%\end{array}$ & $\begin{array}{r}2 \\
1.3 \%\end{array}$ & $\begin{array}{r}3 \\
1.9 \%\end{array}$ & $\begin{array}{r}157 \\
100 \%\end{array}$ \\
\hline $\begin{array}{l}\text { Big Sandy } \\
\text { Appalachian }\end{array}$ & $\begin{array}{r}66 \\
85.7 \%\end{array}$ & $\begin{array}{r}8 \\
10.4 \%\end{array}$ & $\begin{array}{r}3 \\
5.1 \%\end{array}$ & 0 & $\begin{array}{r}77 \\
100 \%\end{array}$ \\
\hline $\begin{array}{l}\text { Bluegrass Rural } \\
\text { Rural }\end{array}$ & $\begin{array}{r}273 \\
85.0 \%\end{array}$ & $\begin{array}{r}34 \\
10.6 \%\end{array}$ & $\begin{array}{r}8 \\
2.5 \%\end{array}$ & $\begin{array}{r}6 \\
1.9 \%\end{array}$ & $\begin{array}{r}321 \\
100 \%\end{array}$ \\
\hline $\begin{array}{l}\text { Bluegrass/Fayette } \\
\text { Urban }\end{array}$ & $\begin{array}{r}70 \\
74.5 \%\end{array}$ & $\begin{array}{r}19 \\
20.2 \%\end{array}$ & $\begin{array}{r}4 \\
4.3 \%\end{array}$ & $\begin{array}{r}1 \\
1.1 \%\end{array}$ & $\begin{array}{r}94 \\
100 \%\end{array}$ \\
\hline $\begin{array}{l}\text { Cumberland Valley } \\
\text { Appalachian }\end{array}$ & $\begin{array}{r}130 \\
77.8 \%\end{array}$ & $\begin{array}{r}28 \\
16.8 \%\end{array}$ & $\begin{array}{r}9 \\
5.4 \%\end{array}$ & & $\begin{array}{r}167 \\
100 \%\end{array}$ \\
\hline $\begin{array}{l}\text { Fivco } \\
\text { Appalachian }\end{array}$ & $\begin{array}{r}70 \\
84.3 \%\end{array}$ & $\begin{array}{r}12 \\
14.5 \%\end{array}$ & $\begin{array}{r}1 \\
1.2 \%\end{array}$ & 0 & $\begin{array}{r}83 \\
100 \%\end{array}$ \\
\hline $\begin{array}{l}\text { Gateway/Buffalo Trace } \\
\text { Appalachian }\end{array}$ & $\begin{array}{r}100 \\
90.1 \%\end{array}$ & $\begin{array}{r}9 \\
8.1 \%\end{array}$ & $\begin{array}{r}1 \\
.9 \%\end{array}$ & $\begin{array}{r}1 \\
.9 \%\end{array}$ & $\begin{array}{r}111 \\
100 \%\end{array}$ \\
\hline $\begin{array}{l}\text { Green River } \\
\text { Urban }\end{array}$ & $\begin{array}{r}153 \\
91.6 \%\end{array}$ & $\begin{array}{r}12 \\
7.2 \%\end{array}$ & $\begin{array}{r}1 \\
.6 \%\end{array}$ & $\begin{array}{r}1 \\
.6 \%\end{array}$ & $\begin{array}{r}167 \\
100 \%\end{array}$ \\
\hline $\begin{array}{l}\text { Kentucky River } \\
\text { Appalachian }\end{array}$ & $\begin{array}{r}81 \\
81 \%\end{array}$ & $\begin{array}{r}13 \\
13 \%\end{array}$ & $\begin{array}{r}5 \\
5 \%\end{array}$ & $\begin{array}{r}1 \\
1 \%\end{array}$ & $\begin{array}{r}100 \\
100 \%\end{array}$ \\
\hline $\begin{array}{l}\text { KIPDA Jefferson } \\
\text { Urban }\end{array}$ & $\begin{array}{r}393 \\
86.8 \%\end{array}$ & $\begin{array}{r}54 \\
11.9 \%\end{array}$ & $\begin{array}{r}5 \\
1.1 \%\end{array}$ & $\begin{array}{r}1 \\
.2 \%\end{array}$ & $\begin{array}{r}453 \\
100 \%\end{array}$ \\
\hline $\begin{array}{l}\text { KIPDA Rural } \\
\text { Rural }\end{array}$ & $\begin{array}{r}51 \\
81 \%\end{array}$ & $\begin{array}{r}11 \\
17.5 \%\end{array}$ & 0 & $\begin{array}{r}1 \\
1.6 \%\end{array}$ & $\begin{array}{r}63 \\
100 \%\end{array}$ \\
\hline $\begin{array}{l}\text { Lake Cumberland } \\
\text { Appalachian }\end{array}$ & $\begin{array}{r}108 \\
85.7 \%\end{array}$ & $\begin{array}{r}15 \\
11.9 \%\end{array}$ & $\begin{array}{r}2 \\
1.6 \%\end{array}$ & $\begin{array}{r}1 \\
.8 \%\end{array}$ & $\begin{array}{r}126 \\
100 \%\end{array}$ \\
\hline $\begin{array}{l}\text { Lincoln Trail } \\
\text { Rural }\end{array}$ & $\begin{array}{r}119 \\
79.9 \%\end{array}$ & $\begin{array}{r}26 \\
17.4 \%\end{array}$ & $\begin{array}{r}3 \\
2 \%\end{array}$ & $\begin{array}{r}1 \\
.7 \%\end{array}$ & $\begin{array}{r}149 \\
100 \%\end{array}$ \\
\hline $\begin{array}{l}\text { Northern Kentucky } \\
\text { Urban }\end{array}$ & $\begin{array}{r}180 \\
76.3 \%\end{array}$ & $\begin{array}{r}47 \\
19.9 \%\end{array}$ & $\begin{array}{r}7 \\
3.0 \%\end{array}$ & $\begin{array}{r}2 \\
.8 \%\end{array}$ & $\begin{array}{r}236 \\
100 \%\end{array}$ \\
\hline $\begin{array}{l}\text { Pennyrile } \\
\text { Urban }\end{array}$ & $\begin{array}{r}83 \\
75.5 \%\end{array}$ & $\begin{array}{r}20 \\
5.8 \%\end{array}$ & $\begin{array}{r}5 \\
4.5 \%\end{array}$ & $\begin{array}{r}2 \\
1.8 \%\end{array}$ & $\begin{array}{r}110 \\
100 \%\end{array}$ \\
\hline
\end{tabular}


Table 16 (Continued)

Crosstabulation of Closing Cumulative CQA Scores by Region*

Purchase

Rural

Total
33
$64.7 \%$

15
$29.4 \%$

347

$14.1 \%$

2038

$82.7 \%$

${ }^{*}$ Count and percentage of region population with closing cumulative CQA score

Note. $364(12.9 \%)$ cases did not have a closing cumulative CQA score

\section{Table 17}

Crosstabulation of Closing Cumulative CQA Scores by Geographic Region*

\begin{tabular}{lrrrrrr}
\hline $\begin{array}{c}\text { Region/ } \\
\text { Geographic } \\
\text { Classification** }\end{array}$ & Change in CQA Between Opening and Closing \\
& $\begin{array}{l}\text { Lowest } \\
\text { thru0 }\end{array}$ & $1-7$ & $8-14$ & $15-21$ & $22-28$ & Total \\
\hline $\begin{array}{l}\text { Regions within } \\
\text { Appalachia }\end{array}$ & $12 \%$ & 205 & 251 & 120 & 8 & 664 \\
Regions Urban & 106 & 479 & 350 & 114 & 11 & $100 \%$ \\
Areas & $10 \%$ & $45.2 \%$ & $33 \%$ & $10.8 \%$ & $1 \%$ & \\
& 95 & 303 & 246 & 94 & 3 & 741 \\
Rural regions & $12.8 \%$ & $40.9 \%$ & $33.2 \%$ & $12.7 \%$ & $.4 \%$ & $100 \%$ \\
\hline
\end{tabular}

* Oneway ANOVA Between groups $p<.001$ for change and Geographic region

${ }^{* *}$ Geographic classification of cases indicated on Table 16

scores between opening and closing, however, found a significant difference $(p<$ .001) in CQA change between opening and closing (Table 17). Fifty-seven percent of the cases in regions classified as Appalachia showed at least 8 risk points of change, while cases having at least 8 risk points of change was less in urban $(44.8 \%)$ and rural regions (46.3\%).

\section{Results of Chi-Square Testing}

Bivariate analysis was used to examine relationships and differences in case variables and reduction in risk. Case characteristics by cumulative CQA 
rating at case closure (Table 18) presents case variables with an association to the cumulative CQA rating by level of risk at case closure. Case characteristics by reduction in cumulative CQA Rating, opening to closing (Table 19) presents case variables associated with reduction in the CQA cumulative score from opening to closing. Levels of reduction were classified as: (a) lowest to 0 points of reduction (this would include cases with an increase in CQA score between opening and closing), (b) 1 to 7 points of reduction, (c) 8 to 14 points of reduction, and (d) 15 to 28 points of reduction. Case characteristics by reduction in Mudd safety CQA rating, opening to closing (Table 20), presents the variables associated with reduction in the safety score from opening to closing CQA. Levels of reduction were classified as: (a) lowest to 0 points of reduction (this would include cases with an increase in safety score between opening and closing), (b) 1 to 6 points of reduction, (c) 7 to 10 points of reduction, and (d) 11 to 16 points of reduction. Variables were recoded as needed to increase the manageability of the data. This study of the CQA tool was one of two early studies, the other being Huebner (2002), which examined the CQA tool. Thus, the cumulative CQA rating at case closure also provides a baseline for future studies.

\section{Restatement of and Answer to Question One}

What are the relationships of change from the level of risk measured by the first Continuous Quality Assessment (CQA) at case opening to the level of risk measured by the last CQA at case closure? 
Table 18

Results of Chi-Square Testing: Case Characteristics by Cumulative CQA

\section{Rating at Case Closure}

\begin{tabular}{|c|c|c|c|c|c|c|c|}
\hline \multirow{2}{*}{\begin{tabular}{|l|} 
Case \\
Characteristics \\
\end{tabular}} & \multicolumn{4}{|c|}{ Classification of Risk at Case Closure } & \multirow{2}{*}{$\begin{array}{l}\text { Chi- } \\
\text { Square }\end{array}$} & \multirow[t]{2}{*}{$d f$} & \multirow[t]{2}{*}{ Sig. } \\
\hline & $\begin{array}{r}\text { Low } \\
\text { Risk } \\
(0-6.9)\end{array}$ & $\begin{array}{r}\text { Moderate } \\
\text { Risk } \\
(7-13.9)\end{array}$ & $\begin{array}{r}\text { Significant } \\
\text { Risk } \\
(14-19.9)\end{array}$ & $\begin{array}{r}\text { High } \\
\text { Risk } \\
(20-28)\end{array}$ & & & \\
\hline Program & & & & & 18.872 & 9 & .026 \\
\hline $\begin{array}{l}\text { Placement } \\
(n=364)\end{array}$ & $\begin{array}{r}281 \\
77,2 \%\end{array}$ & $\begin{array}{r}60 \\
16.5 \% \\
\end{array}$ & $\begin{array}{r}17 \\
4.7 \% \\
\end{array}$ & $\begin{array}{r}6 \\
1.6 \%\end{array}$ & & & \\
\hline $\begin{array}{l}\text { Neglect } \\
(n=935)\end{array}$ & $\begin{array}{r}791 \\
84.6 \% \\
\end{array}$ & $\begin{array}{r}120 \\
12.8 \% \\
\end{array}$ & $\begin{array}{r}17 \\
1.8 \% \\
\end{array}$ & $\begin{array}{r}7 \\
.7 \% \\
\end{array}$ & & & \\
\hline $\begin{array}{l}\text { Physical } \\
(n=520)\end{array}$ & $\begin{array}{r}434 \\
83.5 \%\end{array}$ & $\begin{array}{r}75 \\
14.4 \%\end{array}$ & $\begin{array}{r}8 \\
1.5 \%\end{array}$ & $\begin{array}{r}3 \\
.6 \%\end{array}$ & & & \\
\hline $\begin{array}{l}\text { Other } \\
(n=588)\end{array}$ & $\begin{array}{r}485 \\
82.5 \% \\
\end{array}$ & $\begin{array}{r}83 \\
14.1 \% \\
\end{array}$ & $\begin{array}{r}16 \\
2.7 \% \\
\end{array}$ & $\begin{array}{r}4 \\
.7 \% \\
\end{array}$ & & & \\
\hline Prior Case & & & & & 10.800 & 3 & .018 \\
\hline $\begin{array}{l}\text { Yes } \\
(n=1,288)\end{array}$ & $\begin{array}{r}1,037 \\
80.5 \%\end{array}$ & $\begin{array}{r}205 \\
15.9 \%\end{array}$ & $\begin{array}{r}36 \\
2.8 \%\end{array}$ & $\begin{array}{r}10 \\
.8 \%\end{array}$ & & & \\
\hline $\begin{array}{l}\text { No } \\
(n=1,177)\end{array}$ & $\begin{array}{r}1,001 \\
85 \% \\
\end{array}$ & $\begin{array}{r}142 \\
12.1 \%\end{array}$ & $\begin{array}{r}23 \\
2 \%\end{array}$ & $\begin{array}{r}11 \\
.9 \% \\
\end{array}$ & & & \\
\hline Sup. Gender & & & & & 20.904 & 3 & .000 \\
\hline $\begin{array}{l}\text { Male } \\
(n=598)\end{array}$ & $\begin{array}{r}480 \\
80.3 \%\end{array}$ & $\begin{array}{r}92 \\
15.4 \%\end{array}$ & $\begin{array}{r}13 \\
2.2 \%\end{array}$ & $\begin{array}{r}13 \\
2.2 \%\end{array}$ & & & \\
\hline $\begin{array}{l}\text { Female } \\
(n=1793)\end{array}$ & $\begin{array}{r}1501 \\
83.7 \% \\
\end{array}$ & $\begin{array}{r}243 \\
13.6 \%\end{array}$ & $\begin{array}{r}43 \\
2.4 \%\end{array}$ & $\begin{array}{l}6 \\
.3\end{array}$ & & & \\
\hline \multicolumn{8}{|l|}{$\begin{array}{l}\text { Risk Fields } \\
\text { (Opening) }\end{array}$} \\
\hline Maltreatment & & & & & 32.364 & 12 & .001 \\
\hline $\begin{array}{l}(0) \\
(n=567)\end{array}$ & $\begin{array}{r}479 \\
84.5 \%\end{array}$ & $\begin{array}{r}73 \\
2.8 \%\end{array}$ & $\begin{array}{r}11 \\
1.9 \%\end{array}$ & $\begin{array}{r}4 \\
.7 \%\end{array}$ & & & \\
\hline $\begin{array}{l}(1) \\
(n=315)\end{array}$ & $\begin{array}{r}272 \\
86.3 \%\end{array}$ & $\begin{array}{r}37 \\
11.7 \%\end{array}$ & $\begin{array}{r}5 \\
1.6 \%\end{array}$ & $\begin{array}{r}1 \\
.3 \%\end{array}$ & & & \\
\hline $\begin{array}{l}(2) \\
(n=634)\end{array}$ & $\begin{array}{r}515 \\
81.2 \%\end{array}$ & $\begin{array}{r}92 \\
14.5 \%\end{array}$ & $\begin{array}{r}18 \\
2.8 \%\end{array}$ & $\begin{array}{r}9 \\
2.8 \%\end{array}$ & & & \\
\hline $\begin{array}{l}(3) \\
(n=604)\end{array}$ & $\begin{array}{r}486 \\
80.5 \%\end{array}$ & $\begin{array}{r}105 \\
17.4 \%\end{array}$ & $\begin{array}{r}12 \\
2 \%\end{array}$ & $\begin{array}{r}1 \\
.2 \%\end{array}$ & & & \\
\hline $\begin{array}{l}(4) \\
(n=449)\end{array}$ & $\begin{array}{r}347 \\
77.3 \% \\
\end{array}$ & $\begin{array}{r}72 \\
16 \% \\
\end{array}$ & $\begin{array}{r}21 \\
4.7 \% \\
\end{array}$ & $\begin{array}{r}9 \\
2 \% \\
\end{array}$ & & & \\
\hline $\begin{array}{l}\text { Sequence of } \\
\text { Events }\end{array}$ & & & & & 33.347 & 12 & .001 \\
\hline $\begin{array}{l}(0) \\
(n=374)\end{array}$ & $\begin{array}{r}319 \\
85.3 \%\end{array}$ & $\begin{array}{r}46 \\
12.3 \%\end{array}$ & $\begin{array}{r}6 \\
1.6 \%\end{array}$ & $\begin{array}{r}3 \\
.8 \%\end{array}$ & & & \\
\hline $\begin{array}{l}(1) \\
(n=430)\end{array}$ & $\begin{array}{r}370 \\
86 \%\end{array}$ & $\begin{array}{r}54 \\
12.6 \%\end{array}$ & $\begin{array}{r}6 \\
1.4 \%\end{array}$ & 0 & & & \\
\hline $\begin{array}{l}(2) \\
(n=816)\end{array}$ & $\begin{array}{r}667 \\
81.7 \% \\
\end{array}$ & $\begin{array}{r}113 \\
13.8 \% \\
\end{array}$ & $\begin{array}{r}27 \\
3.3 \% \\
\end{array}$ & $\begin{array}{r}9 \\
1.1 \% \\
\end{array}$ & & & \\
\hline
\end{tabular}


Table 18 (Continued)

Results of Chi-Square Testing: Case Characteristics by Cumulative CQA

Rating at Case Closure

\begin{tabular}{|c|c|c|c|c|c|c|c|}
\hline \multirow{2}{*}{\begin{tabular}{|l|} 
Case \\
Characteristics \\
\end{tabular}} & \multicolumn{4}{|c|}{ Classification of Risk at Case Closure } & \multirow{2}{*}{$\begin{array}{l}\text { Chi- } \\
\text { Square }\end{array}$} & \multirow[t]{2}{*}{$d f$} & \multirow[t]{2}{*}{ Sig. } \\
\hline & $\begin{array}{r}\text { Low } \\
\text { Risk } \\
(0-6.9)\end{array}$ & $\begin{array}{r}\text { Moderate } \\
\text { Risk } \\
(7-13.9) \\
\end{array}$ & $\begin{array}{r}\text { Significant } \\
\text { Risk } \\
(14-19.9) \\
\end{array}$ & $\begin{array}{r}\text { High } \\
\text { Risk } \\
(20-28) \\
\end{array}$ & & & \\
\hline \multicolumn{8}{|l|}{ Sequence (Cont.) } \\
\hline $\begin{array}{l}(3) \\
(n=671)\end{array}$ & $\begin{array}{r}539 \\
80.3 \% \\
\end{array}$ & $\begin{array}{r}108 \\
16.1 \%\end{array}$ & $\begin{array}{r}19 \\
2.8 \%\end{array}$ & $\begin{array}{r}5 \\
.7 \%\end{array}$ & & & \\
\hline $\begin{array}{l}(4) \\
(n=278)\end{array}$ & $\begin{array}{r}204 \\
73.4 \%\end{array}$ & $\begin{array}{r}58 \\
20.9 \%\end{array}$ & $\begin{array}{r}9 \\
3.2 \%\end{array}$ & $\begin{array}{r}7 \\
2.5 \%\end{array}$ & & & \\
\hline Family Devel. & & & & & 73.290 & 12 & .000 \\
\hline $\begin{array}{l}(0) \\
(n=354)\end{array}$ & $\begin{array}{r}324 \\
91.5 \%\end{array}$ & $\begin{array}{r}26 \\
7.3 \%\end{array}$ & $\begin{array}{r}3 \\
.8 \%\end{array}$ & $\begin{array}{r}1 \\
.3 \%\end{array}$ & & & \\
\hline $\begin{array}{l}(1) \\
(n=752)\end{array}$ & $\begin{array}{r}650 \\
86.4 \%\end{array}$ & $\begin{array}{r}86 \\
11.4 \%\end{array}$ & $\begin{array}{r}13 \\
1.7 \%\end{array}$ & $\begin{array}{r}3 \\
.4 \%\end{array}$ & & & \\
\hline $\begin{array}{l}(2) \\
(n=589)\end{array}$ & $\begin{array}{r}473 \\
80.3 \%\end{array}$ & $\begin{array}{r}94 \\
16 \%\end{array}$ & $\begin{array}{r}17 \\
2.9 \%\end{array}$ & $\begin{array}{r}5 \\
.8 \%\end{array}$ & & & \\
\hline $\begin{array}{l}(3) \\
(n=463)\end{array}$ & $\begin{array}{r}348 \\
75.2 \%\end{array}$ & $\begin{array}{r}94 \\
20.3 \%\end{array}$ & $\begin{array}{r}13 \\
2.8 \%\end{array}$ & $\begin{array}{r}8 \\
1.7 \%\end{array}$ & & & \\
\hline $\begin{array}{l}(4) \\
(n=350)\end{array}$ & $\begin{array}{r}255 \\
72.9 \% \\
\end{array}$ & $\begin{array}{r}71 \\
20.3 \% \\
\end{array}$ & $\begin{array}{r}17 \\
4.9 \% \\
\end{array}$ & $\begin{array}{r}7 \\
2 \%\end{array}$ & & & \\
\hline Discipline & & & & & 44.210 & 12 & .000 \\
\hline $\begin{array}{l}(0) \\
(n=1,144)\end{array}$ & $\begin{array}{r}977 \\
85.4 \% \\
\end{array}$ & $\begin{array}{r}144 \\
12.6 \% \\
\end{array}$ & $\begin{array}{r}16 \\
1.4 \% \\
\end{array}$ & $\begin{array}{r}7 \\
.6 \% \\
\end{array}$ & & & \\
\hline $\begin{array}{l}(1) \\
(n=562)\end{array}$ & $\begin{array}{r}464 \\
82.6 \%\end{array}$ & $\begin{array}{r}76 \\
13.5 \%\end{array}$ & $\begin{array}{r}16 \\
2.8 \%\end{array}$ & $\begin{array}{r}6 \\
1.1 \%\end{array}$ & & & \\
\hline $\begin{array}{l}(2) \\
(n=365)\end{array}$ & $\begin{array}{r}283 \\
77.5 \%\end{array}$ & $\begin{array}{r}68 \\
18.6 \%\end{array}$ & $\begin{array}{r}10 \\
2.7 \%\end{array}$ & $\begin{array}{r}4 \\
1.1 \%\end{array}$ & & & \\
\hline $\begin{array}{l}(3) \\
(n=229)\end{array}$ & $\begin{array}{r}177 \\
77.3 \%\end{array}$ & $\begin{array}{r}38 \\
16.6 \%\end{array}$ & $\begin{array}{r}11 \\
4.8 \% \\
\end{array}$ & $\begin{array}{r}3 \\
1.3 \%\end{array}$ & & & \\
\hline $\begin{array}{l}(4) \\
(n=132)\end{array}$ & $\begin{array}{r}90 \\
68.2 \%\end{array}$ & $\begin{array}{r}31 \\
23.5 \%\end{array}$ & $\begin{array}{r}7 \\
5.3 \%\end{array}$ & $\begin{array}{r}4 \\
3 \%\end{array}$ & & & \\
\hline Adult Patterns & & & & & 60.330 & 12 & .000 \\
\hline $\begin{array}{l}(0) \\
(n=275)\end{array}$ & $\begin{array}{r}248 \\
90.2 \%\end{array}$ & $\begin{array}{r}23 \\
8.4 \%\end{array}$ & $\begin{array}{r}3 \\
1.1 \%\end{array}$ & $\begin{array}{r}1 \\
.4 \%\end{array}$ & & & \\
\hline $\begin{array}{l}(1) \\
(n=537)\end{array}$ & $\begin{array}{r}473 \\
88.1 \%\end{array}$ & $\begin{array}{r}51 \\
13.7 \%\end{array}$ & $\begin{array}{r}9 \\
1.7 \%\end{array}$ & $\begin{array}{r}4 \\
.7 \%\end{array}$ & & & \\
\hline $\begin{array}{l}(2) \\
(n=634)\end{array}$ & $\begin{array}{r}513 \\
80.9 \%\end{array}$ & $\begin{array}{r}101 \\
15.9 \%\end{array}$ & $\begin{array}{r}15 \\
2.4 \%\end{array}$ & $\begin{array}{r}5 \\
.8 \%\end{array}$ & & & \\
\hline $\begin{array}{l}(3) \\
(n=469)\end{array}$ & $\begin{array}{r}384 \\
81.9 \%\end{array}$ & $\begin{array}{r}68 \\
14.5 \%\end{array}$ & $\begin{array}{r}14 \\
3 \%\end{array}$ & $\begin{array}{r}3 \\
.6 \%\end{array}$ & & & \\
\hline $\begin{array}{l}(4) \\
(n=605)\end{array}$ & $\begin{array}{r}443 \\
73.2 \%\end{array}$ & $\begin{array}{r}129 \\
21.3 \%\end{array}$ & $\begin{array}{r}22 \\
3.6 \% \\
\end{array}$ & $\begin{array}{r}11 \\
1.8 \%\end{array}$ & & & \\
\hline Child Devel. & & & & & 24.657 & 12 & .017 \\
\hline $\begin{array}{l}(0) \\
(n=937)\end{array}$ & $\begin{array}{r}799 \\
85.3 \% \\
\end{array}$ & $\begin{array}{r}112 \\
12 \%\end{array}$ & $\begin{array}{r}19 \\
2 \%\end{array}$ & $\begin{array}{r}7 \\
.7 \% \\
\end{array}$ & & & \\
\hline
\end{tabular}


Table 18 (continued)

Results of Chi-Square Testing: Case Characteristics by Cumulative CQA

\section{Rating at Case Closure}

\begin{tabular}{|c|c|c|c|c|c|c|c|}
\hline \multirow[t]{2}{*}{$\begin{array}{l}\text { Case } \\
\text { Characteristics }\end{array}$} & \multicolumn{4}{|c|}{$\begin{array}{c}\text { Classification of Risk at Case } \\
\text { Closure }\end{array}$} & \multirow[t]{2}{*}{$\begin{array}{l}\text { Chi- } \\
\text { Square }\end{array}$} & \multirow[t]{2}{*}{$d f$} & \multirow[t]{2}{*}{ Sig. } \\
\hline & $\begin{array}{r}\text { Low } \\
\text { Risk } \\
(0-6.9)\end{array}$ & $\begin{array}{r}\text { Moderate } \\
\text { Risk } \\
(7-13.9)\end{array}$ & $\begin{array}{r}\text { Significant } \\
\text { Risk } \\
(14-19.9)\end{array}$ & $\begin{array}{r}\text { High } \\
\text { Risk } \\
(20-28) \\
\end{array}$ & & & \\
\hline \multicolumn{8}{|l|}{ Child Devel. (Cont.) } \\
\hline $\begin{array}{l}(1) \\
(n=654)\end{array}$ & $\begin{array}{r}538 \\
82.3 \% \\
\end{array}$ & $\begin{array}{r}96 \\
14.7 \%\end{array}$ & $\begin{array}{r}15 \\
2.3 \%\end{array}$ & $\begin{array}{r}5 \\
.8 \%\end{array}$ & & & \\
\hline $\begin{array}{l}(2) \\
(n=464)\end{array}$ & $\begin{array}{r}373 \\
80.4 \% \\
\end{array}$ & $\begin{array}{r}74 \\
15.9 \%\end{array}$ & $\begin{array}{r}13 \\
2.8 \%\end{array}$ & $\begin{array}{r}4 \\
.9 \%\end{array}$ & & & \\
\hline $\begin{array}{l}(3) \\
(n=320)\end{array}$ & $\begin{array}{r}242 \\
75.6 \% \\
\end{array}$ & $\begin{array}{r}62 \\
19.4 \%\end{array}$ & $\begin{array}{r}10 \\
3.1 \%\end{array}$ & $\begin{array}{r}6 \\
1.9 \%\end{array}$ & & & \\
\hline $\begin{array}{l}(4) \\
(n=141)\end{array}$ & $\begin{array}{r}105 \\
74.5 \% \\
\end{array}$ & $\begin{array}{r}27 \\
19.1 \%\end{array}$ & $\begin{array}{r}7 \\
5 \%\end{array}$ & $\begin{array}{r}2 \\
1.4 \%\end{array}$ & & & \\
\hline Family Sup. & & & & & 63.832 & 12 & .000 \\
\hline $\begin{array}{l}(0) \\
(n=1,334)\end{array}$ & $\begin{array}{r}1142 \\
85.6 \%\end{array}$ & $\begin{array}{r}158 \\
11.8 \%\end{array}$ & $\begin{array}{r}27 \\
2 \%\end{array}$ & $\begin{array}{r}7 \\
2 \%\end{array}$ & & & \\
\hline $\begin{array}{l}(1) \\
(n=625)\end{array}$ & $\begin{array}{r}496 \\
79.4 \% \\
\end{array}$ & $\begin{array}{r}111 \\
17.8 \% \\
\end{array}$ & $\begin{array}{r}15 \\
2.4 \% \\
\end{array}$ & $\begin{array}{r}33 \\
.5 \% \\
\end{array}$ & & & \\
\hline \multicolumn{8}{|l|}{ Support Con. } \\
\hline $\begin{array}{l}(2) \\
(n=412)\end{array}$ & $\begin{array}{r}318 \\
77.2 \% \\
\end{array}$ & $\begin{array}{r}67 \\
16.3 \%\end{array}$ & $\begin{array}{r}18 \\
4.4 \% \\
\end{array}$ & $\begin{array}{r}9 \\
2.2 \%\end{array}$ & & & \\
\hline $\begin{array}{l}(3) \\
(n=103)\end{array}$ & $\begin{array}{r}65 \\
63.1 \% \\
\end{array}$ & $\begin{array}{r}29 \\
28.2 \%\end{array}$ & $\begin{array}{r}5 \\
4.9 \% \\
\end{array}$ & $\begin{array}{r}4 \\
3.9 \% \\
\end{array}$ & & & \\
\hline $\begin{array}{l}(4) \\
(n=53)\end{array}$ & $\begin{array}{r}45 \\
84.9 \% \\
\end{array}$ & $\begin{array}{r}7 \\
13.2 \%\end{array}$ & 0 & $\begin{array}{r}1 \\
1.9 \%\end{array}$ & & & \\
\hline Sup. Area Study & & & & & 11.779 & 6 & .067 \\
\hline $\begin{array}{l}\text { Social Work } \\
(n=1,071)\end{array}$ & $\begin{array}{r}883 \\
82.4 \% \\
\end{array}$ & $\begin{array}{r}149 \\
13.9 \%\end{array}$ & $\begin{array}{r}33 \\
3.1 \% \\
\end{array}$ & $\begin{array}{r}6 \\
.6 \%\end{array}$ & & & \\
\hline $\begin{array}{l}\text { COA Related } \\
(n=791)\end{array}$ & $\begin{array}{r}667 \\
84.3 \%\end{array}$ & $\begin{array}{r}105 \\
13.3 \%\end{array}$ & $\begin{array}{r}15 \\
1.9 \%\end{array}$ & $\begin{array}{r}4 \\
.5 \%\end{array}$ & & & \\
\hline $\begin{array}{l}\text { Other } \\
(n=554)\end{array}$ & $\begin{array}{r}453 \\
82.9 \% \\
\end{array}$ & $\begin{array}{r}83 \\
15 \%\end{array}$ & $\begin{array}{r}9 \\
1.6 \%\end{array}$ & $\begin{array}{r}9 \\
1.6 \%\end{array}$ & & & \\
\hline $\begin{array}{l}\text { No. Sub. Ref. At } \\
\text { Closure }\end{array}$ & & & & & 17.810 & 9 & .037 \\
\hline $\begin{array}{l}1 \\
(n=1,423)\end{array}$ & $\begin{array}{r}1,212 \\
85.2 \%\end{array}$ & $\begin{array}{r}171 \\
12 \%\end{array}$ & $\begin{array}{r}29 \\
2 \%\end{array}$ & $\begin{array}{r}11 \\
.8 \%\end{array}$ & & & \\
\hline$(n=544)$ & $\begin{array}{r}433 \\
79.6 \%\end{array}$ & $\begin{array}{r}88 \\
16.2 \%\end{array}$ & $\begin{array}{r}17 \\
3.1 \%\end{array}$ & $\begin{array}{r}6 \\
1.1 \%\end{array}$ & & & \\
\hline $\begin{array}{l}3 \\
(n=194)\end{array}$ & \begin{tabular}{r|}
158 \\
$81.4 \%$
\end{tabular} & $\begin{array}{r}29.210 \\
14.9 \%\end{array}$ & $\begin{array}{rl}5 & 5 \\
2.6 \%\end{array}$ & $\begin{aligned} 2 \\
1 \%\end{aligned}$ & & & \\
\hline $\begin{array}{l}\text { Over } 3 \\
(n=304)\end{array}$ & $\begin{array}{r}235 \\
77.3 \%\end{array}$ & $\begin{array}{r}59 \\
19.4 \%\end{array}$ & $\begin{array}{r}8.07 \\
2.6 \%\end{array}$ & $\begin{array}{r}2 \\
.7 \%\end{array}$ & & & \\
\hline
\end{tabular}


Table 19

Results of Chi-Square Testing: Case Characteristics by Reduction in

Cumulative CQA Rating, Opening to Closing

\begin{tabular}{|c|c|c|c|c|c|c|c|}
\hline \multirow[t]{2}{*}{$\begin{array}{l}\text { Case } \\
\text { Characteristics }\end{array}$} & \multicolumn{4}{|c|}{$\begin{array}{c}\text { Reduction in CQA Risk Rating } \\
\text { Opening and Closing }\end{array}$} & \multirow[t]{2}{*}{$\begin{array}{l}\text { Chi- } \\
\text { Square }\end{array}$} & \multirow[t]{2}{*}{$d f$} & \multirow[t]{2}{*}{ Sig. } \\
\hline & $\begin{array}{c}\text { Lowest- } \\
0\end{array}$ & $1-7$ & $8-14$ & $15-28$ & & & \\
\hline Region & & & & & 120.811 & 45 & .000 \\
\hline $\begin{array}{l}\text { Barren River } \\
(n=157)\end{array}$ & $\begin{array}{r}20 \\
12.7 \%\end{array}$ & $\begin{array}{r}64 \\
40.8 \%\end{array}$ & $\begin{array}{r}47 \\
29.9 \%\end{array}$ & $\begin{array}{r}26 \\
16.6 \%\end{array}$ & & & \\
\hline $\begin{array}{l}\text { Big Sandy } \\
(n=77)\end{array}$ & $\begin{array}{r}9 \\
11.7 \%\end{array}$ & $\begin{array}{r}29 \\
37.7 \%\end{array}$ & $\begin{array}{r}26 \\
33.8 \%\end{array}$ & $\begin{array}{r}13 \\
16.9 \%\end{array}$ & & & \\
\hline $\begin{array}{l}\text { Bluegrass/Fayette } \\
(n=94)\end{array}$ & $\begin{array}{r}21 \\
22.3 \%\end{array}$ & $\begin{array}{r}34 \\
36.2 \%\end{array}$ & $\begin{array}{r}28 \\
29.8 \%\end{array}$ & $\begin{array}{r}11 \\
11.7 \%\end{array}$ & & & \\
\hline $\begin{array}{l}\text { Bluegrass Rural } \\
(n=321)\end{array}$ & $\begin{array}{r}47 \\
14.6 \%\end{array}$ & $\begin{array}{r}125 \\
38.9 \%\end{array}$ & $\begin{array}{r}112 \\
34.9 \%\end{array}$ & $\begin{array}{r}37 \\
14.2 \%\end{array}$ & & & \\
\hline $\begin{array}{l}\text { Cumberland Valley } \\
(n=167)\end{array}$ & $\begin{array}{r}19 \\
11.4 \% \\
\end{array}$ & $\begin{array}{r}36 \\
21.6 \% \\
\end{array}$ & $\begin{array}{r}68 \\
40.7 \% \\
\end{array}$ & $\begin{array}{r}45 \\
26.4 \% \\
\end{array}$ & & & \\
\hline $\begin{array}{l}\text { Fivco } \\
(n=83)\end{array}$ & $\begin{array}{r}7 \\
8.4 \%\end{array}$ & $\begin{array}{r}20 \\
24.1 \%\end{array}$ & $\begin{array}{r}32 \\
38.6 \%\end{array}$ & $\begin{array}{r}24 \\
38.6 \%\end{array}$ & & & \\
\hline $\begin{array}{l}\text { Gateway/Buffalo } \\
(n=111)\end{array}$ & $\begin{array}{r}14 \\
12.6 \%\end{array}$ & $\begin{array}{r}46 \\
41.4 \%\end{array}$ & $\begin{array}{r}39 \\
35.1 \%\end{array}$ & $\begin{array}{r}12 \\
10.8 \%\end{array}$ & & & \\
\hline $\begin{array}{l}\text { Green River } \\
(n=167)\end{array}$ & $\begin{array}{r}13 \\
7.8 \% \\
\end{array}$ & $\begin{array}{r}81 \\
48.5 \% \\
\end{array}$ & $\begin{array}{r}53 \\
31.7 \% \\
\end{array}$ & $\begin{array}{r}20 \\
12 \% \\
\end{array}$ & & & \\
\hline $\begin{array}{l}\text { Kentucky River } \\
(n=100)\end{array}$ & $\begin{array}{r}18 \\
18 \%\end{array}$ & $\begin{array}{r}27 \\
27 \% \\
\end{array}$ & $\begin{array}{r}39 \\
39 \%\end{array}$ & $\begin{array}{r}16 \\
16 \% \\
\end{array}$ & & & \\
\hline $\begin{array}{l}\text { KIPDAJjefferson } \\
(n=453)\end{array}$ & $\begin{array}{r}28 \\
6.2 \% \\
\end{array}$ & $\begin{array}{r}206 \\
45.5 \% \\
\end{array}$ & $\begin{array}{r}169 \\
37.3 \% \\
\end{array}$ & $\begin{array}{r}50 \\
11.1 \% \% \\
\end{array}$ & & & \\
\hline $\begin{array}{l}\text { KIPDA/Rural } \\
(n=63)\end{array}$ & $\begin{array}{r}7 \\
11.1 \%\end{array}$ & $\begin{array}{r}22 \\
43.1 \%\end{array}$ & $\begin{array}{r}22 \\
34.9 \%\end{array}$ & $\begin{array}{r}12 \\
19.1 \%\end{array}$ & & & \\
\hline $\begin{array}{l}\text { Lake Cumberland } \\
(n=126)\end{array}$ & $\begin{array}{r}13 \\
10.3 \%\end{array}$ & $\begin{array}{r}47 \\
37.3 \%\end{array}$ & $\begin{array}{r}47 \\
37.3 \%\end{array}$ & $\begin{array}{r}19 \\
15.1\end{array}$ & & & \\
\hline $\begin{array}{l}\text { Lincoln Trail } \\
(n=149)\end{array}$ & $\begin{array}{r}16 \\
10.7 \% \\
\end{array}$ & $\begin{array}{r}70 \\
47 \% \\
\end{array}$ & $\begin{array}{r}45 \\
30.2 \% \\
\end{array}$ & $\begin{array}{r}18 \\
12.1 \% \\
\end{array}$ & & & \\
\hline $\begin{array}{l}\text { Northern KY } \\
(n=236)\end{array}$ & $\begin{array}{r}30 \\
12.7 \%\end{array}$ & $\begin{array}{r}109 \\
46.2 \%\end{array}$ & $\begin{array}{r}64 \\
27.1 \%\end{array}$ & $\begin{array}{r}33 \\
32.7 \%\end{array}$ & & & \\
\hline $\begin{array}{l}\text { Pennyrile } \\
(n=110)\end{array}$ & $\begin{array}{r}14 \\
12.7 \% \\
\end{array}$ & $\begin{array}{r}49 \\
44.5 \% \\
\end{array}$ & $\begin{array}{r}36 \\
32.7 \% \\
\end{array}$ & $\begin{array}{r}11 \\
10 \% \\
\end{array}$ & & & \\
\hline $\begin{array}{l}\text { Purchase } \\
(n=51)\end{array}$ & $\begin{array}{r}5 \\
9.8 \% \\
\end{array}$ & $\begin{array}{r}22 \\
43.1 \% \\
\end{array}$ & $\begin{array}{r}20 \\
39.2 \% \\
\end{array}$ & $\begin{array}{r}4 \\
7.8 \% \\
\end{array}$ & & & \\
\hline Prior Case & & & & & 1.256 & 3 & NS \\
\hline $\begin{array}{l}\text { Yes } \\
(n=1,288)\end{array}$ & $\begin{array}{r}146 \\
11.3 \%\end{array}$ & $\begin{array}{r}528 \\
41 \%\end{array}$ & $\begin{array}{r}431 \\
33.5 \%\end{array}$ & $\begin{array}{r}183 \\
14 \%\end{array}$ & & & \\
\hline $\begin{array}{l}\text { No } \\
(n=1,177)\end{array}$ & $\begin{array}{r}135 \\
11.5 \% \\
\end{array}$ & $\begin{array}{r}459 \\
39 \% \\
\end{array}$ & $\begin{array}{r}416 \\
35.3 \% \\
\end{array}$ & $\begin{array}{r}161 \\
14.2 \% \\
\end{array}$ & & & \\
\hline
\end{tabular}


Table 19 (Continued)

Results of Chi-Square Testing: Case Characteristics by Reduction in Cumulative CQA Rating, Opening to Closing

\begin{tabular}{|c|c|c|c|c|c|c|c|}
\hline \multirow[t]{2}{*}{\begin{tabular}{|l|} 
Case \\
Characteristics \\
\end{tabular}} & \multicolumn{4}{|c|}{$\begin{array}{l}\text { Reduction in CQA Risk Rating } \\
\text { Opening and Closing }\end{array}$} & \multirow[t]{2}{*}{$\begin{array}{l}\text { Chi- } \\
\text { Square }\end{array}$} & \multirow[t]{2}{*}{$d f$} & \multirow[t]{2}{*}{ Sig. } \\
\hline & $\begin{array}{c}\text { Lowest- } \\
0\end{array}$ & $1-7$ & $8-14$ & $15-28$ & & & \\
\hline $\begin{array}{l}\text { Geographic } \\
\text { Region }\end{array}$ & & & & & 44.623 & 6 & .000 \\
\hline $\begin{array}{l}\text { Urban } \\
(n=1,060)\end{array}$ & $\begin{array}{r}106 \\
10 \%\end{array}$ & $\begin{array}{r}479 \\
45.2 \% \\
\end{array}$ & $\begin{array}{r}350 \\
33 \%\end{array}$ & $\begin{array}{r}125 \\
11.8 \%\end{array}$ & & & \\
\hline $\begin{array}{l}\text { Appalachian } \\
(n=664)\end{array}$ & $\begin{array}{r}80 \\
12 \% \\
\end{array}$ & $\begin{array}{r}205 \\
30.9 \% \\
\end{array}$ & $\begin{array}{r}251 \\
37.8 \% \\
\end{array}$ & $\begin{array}{r}128 \\
19.3 \% \\
\end{array}$ & & & \\
\hline $\begin{array}{l}\text { Rural) } \\
(n=741)\end{array}$ & $\begin{array}{r}95 \\
12.8 \% \\
\end{array}$ & $\begin{array}{r}303 \\
40.9 \% \\
\end{array}$ & $\begin{array}{r}246 \\
33.2 \% \\
\end{array}$ & $\begin{array}{r}97 \\
13.1 \% \\
\end{array}$ & & & \\
\hline Program & & & & & 131.281 & 9 & .000 \\
\hline $\begin{array}{l}\text { Placement } \\
(n=364)\end{array}$ & $\begin{array}{r}55 \\
15.1 \% \\
\end{array}$ & $\begin{array}{r}128 \\
35.2 \% \\
\end{array}$ & $\begin{array}{r}109 \\
29.9 \% \\
\end{array}$ & $\begin{array}{r}72 \\
19.8 \%\end{array}$ & & & \\
\hline $\begin{array}{l}\text { Neglect } \\
(n=935)\end{array}$ & $\begin{array}{r}77 \\
8.2 \% \\
\end{array}$ & $\begin{array}{r}352 \\
37.6 \% \\
\end{array}$ & $\begin{array}{r}380 \\
40.6 \% \\
\end{array}$ & $\begin{array}{r}126 \\
13.4 \%\end{array}$ & & & \\
\hline $\begin{array}{l}\text { Physical } \\
(n=520)\end{array}$ & $\begin{array}{r}48 \\
9.2 \% \\
\end{array}$ & $\begin{array}{r}174 \\
33.5 \% \\
\end{array}$ & $\begin{array}{r}225 \\
43.3 \% \\
\end{array}$ & $\begin{array}{r}73 \\
14.1 \% \\
\end{array}$ & & & \\
\hline $\begin{array}{l}\text { Other } \\
(n=588)\end{array}$ & $\begin{array}{r}5 \\
.9 \% \\
\end{array}$ & $\begin{array}{r}311 \\
52.9 \% \\
\end{array}$ & $\begin{array}{r}120 \\
20.4 \% \\
\end{array}$ & $\begin{array}{r}62 \\
10.6 \% \\
\end{array}$ & & & \\
\hline \multicolumn{8}{|l|}{$\begin{array}{l}\text { Risk Fields } \\
\text { (Opening) }\end{array}$} \\
\hline Maltreatment & & & & & 921.713 & 12 & .000 \\
\hline $\begin{array}{l}(0) \\
(n=504)\end{array}$ & $\begin{array}{r}149 \\
29.6 \% \\
\end{array}$ & \begin{tabular}{r|}
308 \\
$61.1 \%$ \\
\end{tabular} & $\begin{array}{r}44 \\
8.7 \% \\
\end{array}$ & $\begin{array}{r}3 \\
.6 \% \\
\end{array}$ & & & \\
\hline $\begin{array}{l}(1) \\
(n=302)\end{array}$ & $\begin{array}{r}42 \\
13.9 \% \\
\end{array}$ & $\begin{array}{r}192 \\
63.6 \% \\
\end{array}$ & $\begin{array}{r}64 \\
21.2 \% \\
\end{array}$ & $\begin{array}{r}4 \\
7.6 \% \\
\end{array}$ & & & \\
\hline $\begin{array}{l}(2) \\
(n=625)\end{array}$ & $\begin{array}{r}52 \\
8.3 \% \\
\end{array}$ & \begin{tabular}{r|}
262 \\
$41.9 \%$ \\
\end{tabular} & $\begin{array}{r}274 \\
43.8 \% \\
\end{array}$ & $\begin{array}{r}37 \\
5.9 \% \\
\end{array}$ & & & \\
\hline $\begin{array}{l}(3) \\
(n=594)\end{array}$ & $\begin{array}{r}20 \\
3.4 \% \\
\end{array}$ & $\begin{array}{r}157 \\
26.4 \% \\
\end{array}$ & $\begin{array}{r}285 \\
48 \% \\
\end{array}$ & $\begin{array}{r}132 \\
22.2 \% \\
\end{array}$ & & & \\
\hline $\begin{array}{l}(4) \\
(n=440)\end{array}$ & $\begin{array}{r}18 \\
4.1 \% \\
\end{array}$ & $\begin{array}{r}68 \\
15.5 \% \\
\end{array}$ & $\begin{array}{r}180 \\
40.9 \% \\
\end{array}$ & $\begin{array}{r}174 \\
39.6 \% \\
\end{array}$ & & & \\
\hline $\begin{array}{l}\text { Sequence of } \\
\text { Events }\end{array}$ & & & & & 1019.39 & 12 & .000 \\
\hline $\begin{array}{l}(0) \\
(n=323)\end{array}$ & $\begin{array}{r}110 \\
34.1 \% \\
\end{array}$ & $\begin{array}{r}191 \\
59.1 \% \\
\end{array}$ & $\begin{array}{r}20 \\
6.2 \% \\
\end{array}$ & $2.6 \%$ & & & \\
\hline $\begin{array}{l}(1) \\
(n=408)\end{array}$ & $\begin{array}{r}66 \\
16.2 \% \\
\end{array}$ & $\begin{array}{r}270 \\
66.2 \% \\
\end{array}$ & $\begin{array}{r}68 \\
16.7 \% \\
\end{array}$ & $\begin{array}{r}4 \\
1 \% \\
\end{array}$ & & & \\
\hline $\begin{array}{l}(2) \\
(n=798)\end{array}$ & $\begin{array}{r}73 \\
9.1 \% \\
\end{array}$ & $\begin{array}{r}364 \\
45.6 \% \\
\end{array}$ & $\begin{array}{r}325 \\
40.7 \% \\
\end{array}$ & $\begin{array}{r}36 \\
4.5 \% \\
\end{array}$ & & & \\
\hline $\begin{array}{l}(3) \\
(n=664)\end{array}$ & $\begin{array}{r}26 \\
3.9 \% \\
\end{array}$ & $\begin{array}{r}133 \\
20 \% \\
\end{array}$ & $\begin{array}{r}320 \\
48.2 \% 1 \\
\end{array}$ & $\begin{array}{r}185 \\
27.9 \% \\
\end{array}$ & & & \\
\hline
\end{tabular}


Table 19 (Continued)

Results of Chi-Square Testing: Case Characteristics by Reduction in

Cumulative CQA Rating, Opening to Closing

\begin{tabular}{|c|c|c|c|c|c|c|c|}
\hline \multirow[t]{2}{*}{$\begin{array}{l}\text { Case } \\
\text { Characteristics }\end{array}$} & \multicolumn{4}{|c|}{$\begin{array}{l}\text { Reduction in CQA Risk Rating } \\
\text { Opening and Closing }\end{array}$} & \multirow[t]{2}{*}{$\begin{array}{l}\text { Chi- } \\
\text { Square }\end{array}$} & \multirow[t]{2}{*}{$d f$} & \multirow[t]{2}{*}{ Sig. } \\
\hline & $\begin{array}{c}\text { Lowest- } \\
0\end{array}$ & $1-7$ & $8-14$ & $15-28$ & & & \\
\hline \multicolumn{8}{|l|}{ Sequence (Cont.) } \\
\hline $\begin{array}{l}(4) \\
(n=272)\end{array}$ & $\begin{array}{r}6 \\
2.2 \% \\
\end{array}$ & $\begin{array}{r}29 \\
10.7 \% \\
\end{array}$ & $\begin{array}{r}114 \\
41.9 \% \\
\end{array}$ & $\begin{array}{r}123 \\
45.2 \%\end{array}$ & & & \\
\hline Family Devel. & & & & & 1060.85 & 12 & .000 \\
\hline $\begin{array}{l}(0) \\
(n=325)\end{array}$ & $\begin{array}{r}96 \\
29.5 \% \\
\end{array}$ & $\begin{array}{r}207 \\
63.7 \% \\
\end{array}$ & $\begin{array}{r}22 \\
6.8 \% \\
\end{array}$ & 0 & & & \\
\hline $\begin{array}{l}(1) \\
(n=709)\end{array}$ & $\begin{array}{r}86 \\
12.1 \% \\
\end{array}$ & $\begin{array}{r}415 \\
58.5 \% \\
\end{array}$ & $\begin{array}{r}202 \\
28.5 \% \\
\end{array}$ & $\begin{array}{r}6 \\
.8 \% \\
\end{array}$ & & & \\
\hline $\begin{array}{l}(2) \\
(n=572)\end{array}$ & $\begin{array}{r}41 \\
7.2 \% \\
\end{array}$ & $\begin{array}{r}211 \\
36.9 \% \\
\end{array}$ & $\begin{array}{r}283 \\
49.5 \% \\
\end{array}$ & $\begin{array}{r}37 \\
6.6 \% \\
\end{array}$ & & & \\
\hline $\begin{array}{l}(3) \\
(n=457)\end{array}$ & $\begin{array}{r}28 \\
6.1 \% \\
\end{array}$ & $\begin{array}{r}78 \\
17.1 \% \\
\end{array}$ & $\begin{array}{r}219 \\
47.9 \% \\
\end{array}$ & $\begin{array}{r}132 \\
28.9 \% \\
\end{array}$ & & & \\
\hline $\begin{array}{l}(4) \\
(n=341)\end{array}$ & $\begin{array}{r}15 \\
4.4 \%\end{array}$ & $\begin{array}{r}37 \\
10.9 \%\end{array}$ & $\begin{array}{r}114 \\
33.4 \% \\
\end{array}$ & $\begin{array}{r}175 \\
51.3 \%\end{array}$ & & & \\
\hline Discipline & & & & & 592.396 & 12 & .000 \\
\hline $\begin{array}{l}(0) \\
(n=1076)\end{array}$ & $\begin{array}{r}153 \\
14.2 \% \\
\end{array}$ & $\begin{array}{r}525 \\
48.8 \% \\
\end{array}$ & $\begin{array}{r}335 \\
31.1 \% \\
\end{array}$ & $\begin{array}{r}63 \\
5.9 \% \\
\end{array}$ & & & \\
\hline $\begin{array}{l}(1) \\
(n=539)\end{array}$ & $\begin{array}{r}60 \\
11.1 \% \\
\end{array}$ & $\begin{array}{r}265 \\
49.2 \% \\
\end{array}$ & $\begin{array}{r}171 \\
31.7 \\
\end{array}$ & $\begin{array}{r}43 \\
8 \%\end{array}$ & & & \\
\hline $\begin{array}{l}(2) \\
(n=360)\end{array}$ & $\begin{array}{r}29 \\
8.1 \%\end{array}$ & \begin{tabular}{r|}
89 \\
$24.7 \%$ \\
\end{tabular} & $\begin{array}{r}178 \\
49.4 \%\end{array}$ & $\begin{array}{r}64 \\
17.8 \%\end{array}$ & & & \\
\hline $\begin{array}{l}(3) \\
(n=225\end{array}$ & $\begin{array}{r}10 \\
4.4 \% \\
\end{array}$ & \begin{tabular}{r|}
29 \\
$12.9 \%$ \\
\end{tabular} & $\begin{array}{r}100 \\
44.4 \% \\
\end{array}$ & $\begin{array}{r}86 \\
38.2 \% \\
\end{array}$ & & & \\
\hline $\begin{array}{l}(4) \\
(n=128)\end{array}$ & $\begin{array}{r}4 \\
3.1 \% \\
\end{array}$ & $\begin{array}{r}10 \\
7.8 \% \\
\end{array}$ & $\begin{array}{r}100 \\
44.4 \% \\
\end{array}$ & $\begin{array}{r}86 \\
38.2 \% \\
\end{array}$ & & & \\
\hline Adult Patterns & & & & & 943.176 & 12 & .000 \\
\hline $\begin{array}{l}(0) \\
(n=256)\end{array}$ & $\begin{array}{r}78 \\
30.5 \% \\
\end{array}$ & $\begin{array}{r}164 \\
64.1 \% \\
\end{array}$ & $\begin{array}{r}14 \\
5.5 \% \\
\end{array}$ & 0 & & & \\
\hline $\begin{array}{l}(1) \\
(n=506)\end{array}$ & $\begin{array}{r}79 \\
15.6 \% \\
\end{array}$ & $\begin{array}{r}311 \\
61.5 \% \\
\end{array}$ & $\begin{array}{r}112 \\
22.1 \% \\
\end{array}$ & $\begin{array}{r}4 \\
.8 \% \\
\end{array}$ & & & \\
\hline $\begin{array}{l}(2) \\
(n=604)\end{array}$ & $\begin{array}{r}53 \\
8.8 \% \\
\end{array}$ & $\begin{array}{r}282 \\
46.7 \% \\
\end{array}$ & $\begin{array}{r}249 \\
41.2 \% \\
\end{array}$ & $\begin{array}{r}20 \\
3.3 \% \\
\end{array}$ & & & \\
\hline $\begin{array}{l}(3) \\
(n=459)\end{array}$ & $\begin{array}{r}26 \\
5.7 \% \\
\end{array}$ & $\begin{array}{r}111 \\
24.2 \% \\
\end{array}$ & $\begin{array}{r}241 \\
52.5 \% \\
\end{array}$ & $\begin{array}{r}81 \\
17.6 \% \\
\end{array}$ & & & \\
\hline $\begin{array}{l}(4) \\
(n=591)\end{array}$ & $\begin{array}{r}30 \\
5.1 \% \\
\end{array}$ & $\begin{array}{r}92 \\
15.6 \% \\
\end{array}$ & $\begin{array}{r}224 \\
37.9 \% \\
\end{array}$ & $\begin{array}{r}245 \\
41.5 \% \\
\end{array}$ & & & \\
\hline $\begin{array}{l}\text { Child } \\
\text { Development }\end{array}$ & & & & & 133.009 & 12 & .000 \\
\hline $\begin{array}{l}(0) \\
(n=890)\end{array}$ & $\begin{array}{r}104 \\
11.7 \%\end{array}$ & $\begin{array}{r}396 \\
44.5 \% \\
\end{array}$ & $\begin{array}{r}308 \\
34.6 \%\end{array}$ & $\begin{array}{r}82 \\
9.2 \%\end{array}$ & & & \\
\hline
\end{tabular}


Table 19 (Continued)

Results of Chi-Square Testing: Case Characteristics by Reduction in

Cumulative CQA Rating, Opening to Closing

\begin{tabular}{|c|c|c|c|c|c|c|c|}
\hline \multirow[t]{2}{*}{$\begin{array}{l}\text { Case } \\
\text { Characteristics }\end{array}$} & \multicolumn{4}{|c|}{$\begin{array}{c}\text { Reduction in CQA Risk Rating } \\
\text { Opening and Closing }\end{array}$} & \multirow[t]{2}{*}{$\begin{array}{l}\text { Chi- } \\
\text { Square }\end{array}$} & \multirow[t]{2}{*}{$d f$} & \multirow[t]{2}{*}{ Sig. } \\
\hline & $\begin{array}{c}\text { Lowest- } \\
0\end{array}$ & $1-7$ & $8-14$ & $15-28$ & & & \\
\hline \multicolumn{8}{|l|}{ Child Dev. (Cont.) } \\
\hline $\begin{array}{l}(1) \\
(n=623)\end{array}$ & $\begin{array}{r}77 \\
12.4 \% \\
\end{array}$ & $\begin{array}{r}274 \\
44 \%\end{array}$ & $\begin{array}{r}207 \\
33.2 \% \\
\end{array}$ & $\begin{array}{r}65 \\
10.4 \%\end{array}$ & & & \\
\hline $\begin{array}{l}(2) \\
(n=452)\end{array}$ & $\begin{array}{r}40 \\
8.8 \% \\
\end{array}$ & $\begin{array}{r}161 \\
35.6 \% \\
\end{array}$ & $\begin{array}{r}173 \\
36.2 \% \\
\end{array}$ & $\begin{array}{r}78 \\
17.3 \% \\
\end{array}$ & & & \\
\hline $\begin{array}{l}(3) \\
(n=312)\end{array}$ & $\begin{array}{r}31 \\
9.9 \%\end{array}$ & $\begin{array}{r}95 \\
30.4 \%\end{array}$ & $\begin{array}{r}113 \\
36.2 \%\end{array}$ & $\begin{array}{r}73 \\
23.4 \%\end{array}$ & & & \\
\hline $\begin{array}{l}(4) \\
(n=135)\end{array}$ & $\begin{array}{r}17 \\
12.6 \% \\
\end{array}$ & $\begin{array}{r}30 \\
22.2 \% \\
\end{array}$ & $\begin{array}{r}36 \\
26.7 \% \\
\end{array}$ & $\begin{array}{r}52 \\
38.5 \%\end{array}$ & & & \\
\hline Family Sup. & & & & & 346.668 & 12 & .000 \\
\hline $\begin{array}{l}(0) \\
(n=1,257)\end{array}$ & $\begin{array}{r}178 \\
14.2 \% \\
\end{array}$ & $\begin{array}{r}582 \\
46.3 \% \\
\end{array}$ & $\begin{array}{r}409 \\
32.5 \% \\
\end{array}$ & $\begin{array}{r}88 \\
7 \% \\
\end{array}$ & & & \\
\hline $\begin{array}{l}(1) \\
(n=607)\end{array}$ & $\begin{array}{r}60 \\
9.9 \%\end{array}$ & $\begin{array}{r}248 \\
40.9 \% \\
\end{array}$ & $\begin{array}{r}223 \\
36.7 \% \\
\end{array}$ & $\begin{array}{r}76 \\
12.5 \% \\
\end{array}$ & & & \\
\hline $\begin{array}{l}(2) \\
(n=406)\end{array}$ & $\begin{array}{r}27 \\
6.7 \% \\
\end{array}$ & $\begin{array}{r}101 \\
24.9 \%\end{array}$ & $\begin{array}{r}163 \\
40.1 \%\end{array}$ & $\begin{array}{r}115 \\
28.3 \%\end{array}$ & & & \\
\hline $\begin{array}{l}(3) \\
(n=100)\end{array}$ & $\begin{array}{r}5 \\
5 \%\end{array}$ & $\begin{array}{r}28 \\
28 \%\end{array}$ & $\begin{array}{r}35 \\
35 \%\end{array}$ & $\begin{array}{r}32 \\
32 \%\end{array}$ & & & \\
\hline $\begin{array}{l}(4) \\
(n=53)\end{array}$ & $\begin{array}{r}1 \\
1.9 \\
\end{array}$ & $\begin{array}{r}1 \\
1.9 \% \\
\end{array}$ & $\begin{array}{r}12 \\
22.6 \% \\
\end{array}$ & $\begin{array}{r}39 \\
73.6 \% \\
\end{array}$ & & & \\
\hline $\begin{array}{l}\text { Time Open } \\
\text { Current Episode }\end{array}$ & & & & & 37.561 & 12 & .000 \\
\hline $\begin{array}{l}\text { Less } 6 \text { months } \\
(\mathrm{n}=399)\end{array}$ & $\begin{array}{r}48 \\
12 \% \\
\end{array}$ & $\begin{array}{r}195 \\
48.9 \% \\
\end{array}$ & $\begin{array}{r}116 \\
29.1 \% \\
\end{array}$ & $\begin{array}{r}38 \\
9.5 \%\end{array}$ & & & \\
\hline $\begin{array}{l}6 \text { to } 9 \text { months } \\
(n=530)\end{array}$ & $\begin{array}{r}60 \\
11.3 \%\end{array}$ & $\begin{array}{r}200 \\
37.3 \%\end{array}$ & $\begin{array}{r}194 \\
36.6 \%\end{array}$ & $\begin{array}{r}74 \\
14 \%\end{array}$ & & & \\
\hline $\begin{array}{l}\text { Over } 9 \text { months } \\
12 \text { months } \\
(n=377)\end{array}$ & $\begin{array}{r}33 \\
8.8 \%\end{array}$ & $\begin{array}{r}149 \\
39.5 \%\end{array}$ & $\begin{array}{r}140 \\
37.1 \%\end{array}$ & $\begin{array}{r}52 \\
13.8 \%\end{array}$ & & & \\
\hline $\begin{array}{l}\text { Over } 12 \text { months } \\
18 \text { months. } \\
(n=507)\end{array}$ & $\begin{array}{r}46 \\
9.1 \%\end{array}$ & $\begin{array}{r}182 \\
35.9 \%\end{array}$ & $\begin{array}{r}194 \\
38.3 \%\end{array}$ & $\begin{array}{r}80 \\
15.8 \%\end{array}$ & & & \\
\hline $\begin{array}{l}\text { Over } 18 \text { months } \\
(n=645)\end{array}$ & $\begin{array}{r}94 \\
14.6 \% \\
\end{array}$ & $\begin{array}{r}259 \\
40.2 \% \\
\end{array}$ & $\begin{array}{r}201 \\
31.2 \% \\
\end{array}$ & $\begin{array}{r}81 \\
12.6 \% \\
\end{array}$ & & & \\
\hline $\begin{array}{l}\text { Sup. Area of } \\
\text { Study }\end{array}$ & & & & & 26.782 & 18 & .08 \\
\hline $\begin{array}{l}\text { Social Work } \\
(n=1,071)\end{array}$ & $\begin{array}{r}124 \\
11.6 \% \\
\end{array}$ & $\begin{array}{r}433 \\
40.3 \% \\
\end{array}$ & $\begin{array}{r}367 \\
34.3 \% \\
\end{array}$ & $\begin{array}{r}147 \\
13.7 \% \\
\end{array}$ & & & \\
\hline $\begin{array}{l}\text { Sociology } \\
(n=202)\end{array}$ & $\begin{array}{r}26 \\
12.9 \%\end{array}$ & $\begin{array}{r}64 \\
31.7 \%\end{array}$ & $\begin{array}{r}75 \\
37.1 \%\end{array}$ & $\begin{array}{r}37 \\
18.3 \%\end{array}$ & & & \\
\hline
\end{tabular}


Table 19 (Continued)

Results of Chi-Square Testing: Case Characteristics by Reduction in

Cumulative CQA Rating, Opening to Closing

\begin{tabular}{|c|c|c|c|c|c|c|c|}
\hline \multirow[t]{2}{*}{$\begin{array}{l}\text { Case } \\
\text { Characteristics }\end{array}$} & \multicolumn{4}{|c|}{$\begin{array}{c}\text { Reduction in CQA Risk Rating } \\
\text { Opening and Closing }\end{array}$} & \multirow[t]{2}{*}{$\begin{array}{l}\text { Chi- } \\
\text { Square }\end{array}$} & \multirow[t]{2}{*}{$d f$} & \multirow[t]{2}{*}{ Sig. } \\
\hline & $\begin{array}{c}\text { Lowest- } \\
0\end{array}$ & $1-7$ & $8-14$ & $15-28$ & & & \\
\hline \multicolumn{8}{|l|}{ Supervisor (Cont.) } \\
\hline $\begin{array}{l}\text { Psychology } \\
(n=363)\end{array}$ & $\begin{array}{r}31 \\
8.5 \% \\
\end{array}$ & $\begin{array}{r}146 \\
40.2 \% \\
\end{array}$ & $\begin{array}{r}141 \\
38.8 \% \\
\end{array}$ & $\begin{array}{r}45 \\
12.4 \% \\
\end{array}$ & & & \\
\hline $\begin{array}{l}\text { Corrections } \\
(n=87)\end{array}$ & $\begin{array}{r}6 \\
6.9 \% \\
\end{array}$ & $\begin{array}{r}37 \\
42.5 \% \\
\end{array}$ & $\begin{array}{r}32 \\
36.8 \% \\
\end{array}$ & $\begin{array}{r}12 \\
13.8 \% \\
\end{array}$ & & & \\
\hline $\begin{array}{l}\text { Counseling } \\
(n=137)\end{array}$ & $\begin{array}{r}12 \\
8.8 \% \\
\end{array}$ & $\begin{array}{r}64 \\
46.7 \% \\
\end{array}$ & $\begin{array}{r}38 \\
27.7 \% \\
\end{array}$ & $\begin{array}{r}23 \\
16.8 \%\end{array}$ & & & \\
\hline $\begin{array}{l}\text { Human Studies } \\
(n=98)\end{array}$ & $\begin{array}{r}7 \\
7.1 \%\end{array}$ & $\begin{array}{r}43 \\
43.9 \%\end{array}$ & $\begin{array}{r}30 \\
30.6 \%\end{array}$ & $\begin{array}{r}18 \\
18.4 \%\end{array}$ & & & \\
\hline $\begin{array}{l}\text { Other/Unspecified } \\
(n=458)\end{array}$ & $\begin{array}{r}65 \\
14.2 \% \\
\end{array}$ & $\begin{array}{r}184 \\
40.2 \% \\
\end{array}$ & $\begin{array}{r}150 \\
32.8 \% \\
\end{array}$ & $\begin{array}{r}59 \\
12.9 \% \\
\end{array}$ & & & \\
\hline
\end{tabular}

Table 20

Results of Chi-Square Testing: Case Characteristics by Reduction in Mudd Safety CQA Rating, Opening to Closing

\begin{tabular}{|c|c|c|c|c|c|c|c|}
\hline \multirow[t]{2}{*}{$\begin{array}{l}\text { Case } \\
\text { Characteristics }\end{array}$} & \multicolumn{4}{|c|}{$\begin{array}{c}\text { Mudd Safety Reduction Between } \\
\text { Opening and Closing }\end{array}$} & \multirow[t]{2}{*}{$\begin{array}{l}\text { Chi- } \\
\text { Square }\end{array}$} & \multirow[t]{2}{*}{$d f$} & \multirow[t]{2}{*}{ Sig. } \\
\hline & $\begin{array}{c}\text { Lowest- } \\
0\end{array}$ & $1-6$ & $7-10$ & $11-16$ & & & \\
\hline Worker Position & & & & & 17.591 & 9 & .040 \\
\hline $\begin{array}{l}\text { Worker } \\
(n=1,561)\end{array}$ & $\begin{array}{r}188 \\
12 \% \\
\end{array}$ & $\begin{array}{r}684 \\
43.8 \% \\
\end{array}$ & $\begin{array}{r}415 \\
26.6 \% \\
\end{array}$ & $\begin{array}{r}274 \\
17.6 \% \\
\end{array}$ & & & \\
\hline $\begin{array}{l}\text { Clinician } \\
(n=730)\end{array}$ & $\begin{array}{r}114 \\
15.6 \% \\
\end{array}$ & $\begin{array}{r}287 \\
39.3 \%\end{array}$ & $\begin{array}{r}194 \\
26.6 \%\end{array}$ & $\begin{array}{r}135 \\
18.5 \%\end{array}$ & & & \\
\hline $\begin{array}{l}\text { Specialist } \\
(n=57)\end{array}$ & $\begin{array}{r}7 \\
12.3 \% \\
\end{array}$ & $\begin{array}{r}30 \\
52.6 \%\end{array}$ & $\begin{array}{r}8 \\
14 . \%\end{array}$ & $\begin{array}{r}12 \\
21.1 \%\end{array}$ & & & \\
\hline $\begin{array}{l}\text { Supervisor } \\
(n=69)\end{array}$ & $\begin{array}{r}14 \\
20.3 \%\end{array}$ & $\begin{array}{r}25 \\
36.2 \%\end{array}$ & $\begin{array}{r}14 \\
20.3 \%\end{array}$ & $\begin{array}{r}16 \\
23.2 \%\end{array}$ & & & \\
\hline Sup. Degree & & & & & 10.661 & 3 & 0.14 \\
\hline $\begin{array}{l}\text { Bachelor } \\
(n=1654)\end{array}$ & $\begin{array}{r}202 \\
12.2 \%\end{array}$ & $\begin{array}{r}681 \\
41.2 \%\end{array}$ & $\begin{array}{r}448 \\
27.1 \%\end{array}$ & $\begin{array}{r}323 \\
19.5 \%\end{array}$ & & & \\
\hline $\begin{array}{l}\text { Masters } \\
(n=822)\end{array}$ & $\begin{array}{r}121 \\
14.7 \% \\
\end{array}$ & $\begin{array}{r}373 \\
45.4 \% \\
\end{array}$ & $\begin{array}{r}195 \\
23.7 \% \\
\end{array}$ & $\begin{array}{r}133 \\
16.2 \% \\
\end{array}$ & & & \\
\hline
\end{tabular}


Table 20 (Continued)

Results of Chi-Square Testing: Case Characteristics by Change in Mudd Safety CQA Rating, Opening to Closing

\begin{tabular}{|c|c|c|c|c|c|c|c|}
\hline \multirow[t]{2}{*}{$\begin{array}{l}\text { Case } \\
\text { Characteristics }\end{array}$} & \multicolumn{4}{|c|}{$\begin{array}{l}\text { Mudd Safety Reduction Between } \\
\text { Opening and Closing }\end{array}$} & \multirow[t]{2}{*}{$\begin{array}{l}\text { Chi- } \\
\text { Square }\end{array}$} & \multirow[t]{2}{*}{$d f$} & \multirow[t]{2}{*}{ Sig. } \\
\hline & $\begin{array}{c}\text { Lowest- } \\
0\end{array}$ & $1-6$ & $7-10$ & $11-16$ & & & \\
\hline Sup. Area Study & & & & & 39.61 & 18 & .002 \\
\hline $\begin{array}{l}\text { Social Work } \\
(n=1,094)\end{array}$ & $\begin{array}{r}148 \\
13.5 \% \\
\end{array}$ & $\begin{array}{r}485 \\
44.3 \% \\
\end{array}$ & $\begin{array}{r}271 \\
24.8 \% \\
\end{array}$ & $\begin{array}{r}190 \\
17.4 \% \\
\end{array}$ & & & \\
\hline $\begin{array}{l}\text { Sociology } \\
(n=208)\end{array}$ & $\begin{array}{r}23 \\
11.1 \% \\
\end{array}$ & $\begin{array}{r}69 \\
33.2 \% \\
\end{array}$ & $\begin{array}{r}60 \\
28.8 \% \\
\end{array}$ & $\begin{array}{r}56 \\
26.9 \%\end{array}$ & & & \\
\hline $\begin{array}{l}\text { Psychology } \\
(n=370)\end{array}$ & $\begin{array}{r}46 \\
12.4 \% \\
\end{array}$ & $\begin{array}{r}141 \\
38.1 \% \\
\end{array}$ & $\begin{array}{r}116 \\
31.4 \% \\
\end{array}$ & $\begin{array}{r}67 \\
18.1 \%\end{array}$ & & & \\
\hline $\begin{array}{l}\text { Corrections } \\
(n=87)\end{array}$ & $\begin{array}{r}11 \\
12.6 \% \\
\end{array}$ & $\begin{array}{r}35 \\
40.2 \% \\
\end{array}$ & $\begin{array}{r}26 \\
29.9 \% \\
\end{array}$ & $\begin{array}{r}15 \\
17.2 \% \\
\end{array}$ & & & \\
\hline $\begin{array}{l}\text { Counseling } \\
(n=142)\end{array}$ & $\begin{array}{r}15 \\
10.6 \% \\
\end{array}$ & $\begin{array}{r}62 \\
43.7 \% \\
\end{array}$ & $\begin{array}{r}32 \\
22.5 \% \\
\end{array}$ & $\begin{array}{r}33 \\
23.2 \% \\
\end{array}$ & & & \\
\hline $\begin{array}{l}\text { Human Studies } \\
(n=100)\end{array}$ & $\begin{array}{r}5 \\
5 . \% \\
\end{array}$ & $\begin{array}{r}47 \\
47 \% \\
\end{array}$ & $\begin{array}{r}25 \\
25 \% \\
\end{array}$ & $\begin{array}{r}23 \\
23 \% \\
\end{array}$ & & & \\
\hline $\begin{array}{l}\text { Other/Unspecified } \\
(n=472)\end{array}$ & $\begin{array}{r}74 \\
15.7 \% \\
\end{array}$ & $\begin{array}{r}215 \\
45.6 \% \\
\end{array}$ & $\begin{array}{r}111 \\
23.5 \% \\
\end{array}$ & $\begin{array}{r}72 \\
15.3 \% \\
\end{array}$ & & & \\
\hline Sup.Gender & & & & & 18.345 & 3 & .000 \\
\hline $\begin{array}{l}\text { Male } \\
(n=615)\end{array}$ & $\begin{array}{r}102 \\
16.6 \% \\
\end{array}$ & $\begin{array}{r}277 \\
45 \% \\
\end{array}$ & $\begin{array}{r}147 \\
23.9 \% \\
\end{array}$ & $\begin{array}{r}89 \\
14.5 \%\end{array}$ & & & \\
\hline $\begin{array}{l}\text { Female } \\
(n=1,833)\end{array}$ & $\begin{array}{r}214 \\
11.7 \%\end{array}$ & $\begin{array}{r}765 \\
41.7 \%\end{array}$ & $\begin{array}{r}491 \\
26.8 \%\end{array}$ & $\begin{array}{r}363 \\
19.8 \%\end{array}$ & & & \\
\hline Worker yrs ser. & & & & & 26.844 & 12 & .008 \\
\hline $\begin{array}{l}\text { Less than } 1 \mathrm{yr} \\
(\mathrm{n}=164)\end{array}$ & $\begin{array}{r}30 \\
18.3 \% \\
\end{array}$ & $\begin{array}{r}69 \\
42.1 \% \\
\end{array}$ & $\begin{array}{r}33 \\
20.1 \% \\
\end{array}$ & $\begin{array}{r}32 \\
19.5 \% \\
\end{array}$ & & & \\
\hline $\begin{array}{l}1 \text { to } 5 \text { yrs } \\
(n=245)\end{array}$ & $\begin{array}{r}31 \\
12.7 \% \\
\end{array}$ & $\begin{array}{r}89 \\
36.3 \% \\
\end{array}$ & $\begin{array}{r}75 \\
30.6 \% \\
\end{array}$ & $\begin{array}{r}50 \\
20.4 \% \\
\end{array}$ & & & \\
\hline $\begin{array}{l}6 \text { to10 yrs } \\
(n=121)\end{array}$ & $\begin{array}{r}20 \\
16.5 \% \\
\end{array}$ & $\begin{array}{r}59 \\
48.8 \% \\
\end{array}$ & $\begin{array}{r}22 \\
18.2 \% \\
\end{array}$ & $\begin{array}{r}20 \\
16.5 \% \\
\end{array}$ & & & \\
\hline $\begin{array}{l}11-20 \text { yrs } \\
(n=38)\end{array}$ & $\begin{array}{r}11 \\
28.9 \%\end{array}$ & $\begin{array}{r}18 \\
47.4 \%\end{array}$ & $\begin{array}{r}8 \\
21.1 \% \\
\end{array}$ & $\begin{array}{r}1 \\
2.6 \% \\
\end{array}$ & & & \\
\hline $\begin{array}{l}\text { Over } 21 \text { yrs } \\
(n=24)\end{array}$ & $\begin{array}{r}2 \\
8.3 \% \\
\end{array}$ & $\begin{array}{r}7 \\
29.2 \% \\
\end{array}$ & $\begin{array}{r}8 \\
33.3 \% \\
\end{array}$ & $\begin{array}{r}7 \\
29.2 \% \\
\end{array}$ & & & \\
\hline $\begin{array}{l}\text { Geographic } \\
\text { Region }\end{array}$ & & & & & 49.014 & 6 & .000 \\
\hline $\begin{array}{l}\text { Urban } \\
(n=1,094)\end{array}$ & $\begin{array}{r}133 \\
12.2 \% \\
\end{array}$ & $\begin{array}{r}494 \\
45.2 \% \\
\end{array}$ & $\begin{array}{r}297 \\
27.1 \% \\
\end{array}$ & $\begin{array}{r}177 \\
25.8 \% \\
\end{array}$ & & & \\
\hline $\begin{array}{l}\text { Appalachian } \\
(\mathrm{n}=686)\end{array}$ & $\begin{array}{r}86 \\
12.5 \% \\
\end{array}$ & $\begin{array}{r}238 \\
34.7 \% \\
\end{array}$ & $\begin{array}{r}185 \\
27 \% \\
\end{array}$ & $\begin{array}{r}177 \\
25.8 \% \\
\end{array}$ & & & \\
\hline $\begin{array}{l}\text { Rural) } \\
(n=742)\end{array}$ & $\begin{array}{r}112 \\
15.1 \%\end{array}$ & $\begin{array}{r}344 \\
46.4 \%\end{array}$ & $\begin{array}{r}167 \\
22.5 \% \\
\end{array}$ & $\begin{array}{r}119 \\
25.5 \% \\
\end{array}$ & & & \\
\hline
\end{tabular}


Table 20 (Continued)

Results of Chi-Square Testing: Case Characteristics by Change in Mudd

Safety CQA Rating, Opening to Closing

\begin{tabular}{|c|c|c|c|c|c|c|c|}
\hline \multirow[t]{2}{*}{$\begin{array}{l}\text { Case } \\
\text { Characteristics }\end{array}$} & \multicolumn{4}{|c|}{$\begin{array}{l}\text { Mudd Safety Reduction Between } \\
\text { Opening and Closing }\end{array}$} & \multirow[t]{2}{*}{$\begin{array}{l}\text { Chi- } \\
\text { Square }\end{array}$} & \multirow[t]{2}{*}{$d f$} & \multirow[t]{2}{*}{ Sig. } \\
\hline & $\begin{array}{l}\text { Lowest- } \\
0\end{array}$ & $1-6$ & $7-10$ & $11-16$ & & & \\
\hline $\begin{array}{l}\text { Time Open } \\
\text { Current Episode }\end{array}$ & & & & & 37.797 & 12 & .000 \\
\hline $\begin{array}{l}\text { Less } 6 \text { months } \\
(n=399)\end{array}$ & $\begin{array}{r}62 \\
15 \%\end{array}$ & $\begin{array}{r}194 \\
47.1 \%\end{array}$ & $\begin{array}{r}101 \\
24.5 \%\end{array}$ & $\begin{array}{r}55 \\
13 / 3 \%\end{array}$ & & & \\
\hline $\begin{array}{l}6 \text { to } 9 \text { months } \\
(n=530)\end{array}$ & $\begin{array}{r}7- \\
13 \%\end{array}$ & $\begin{array}{r}215 \\
39.8 \%\end{array}$ & $\begin{array}{r}144 \\
26.7 \%\end{array}$ & $\begin{array}{r}111 \\
20.6 \%\end{array}$ & & & \\
\hline $\begin{array}{l}\text { Over } 9 \text { months } \\
\text { to } 12 \text { months } \\
(n=377)\end{array}$ & $\begin{array}{r}36 \\
9.2 \%\end{array}$ & $\begin{array}{r}177 \\
45 \%\end{array}$ & $\begin{array}{r}107 \\
27.2 \%\end{array}$ & $\begin{array}{r}73 \\
18.6 \%\end{array}$ & & & \\
\hline $\begin{array}{l}\text { Over } 12 \text { months } \\
\text { to } 18 \text { months. } \\
(n=507)\end{array}$ & $\begin{array}{r}57 \\
10.9 \%\end{array}$ & $\begin{array}{r}200 \\
38.2 \%\end{array}$ & $\begin{array}{r}156 \\
29.8 \%\end{array}$ & $\begin{array}{r}110 \\
21 \%\end{array}$ & & & \\
\hline $\begin{array}{l}\text { Over } 18 \text { months } \\
(n=645)\end{array}$ & $\begin{array}{r}106 \\
16.4 \%\end{array}$ & $\begin{array}{r}289 \\
44.7 \%\end{array}$ & $\begin{array}{r}138 \\
21.3 \%\end{array}$ & $\begin{array}{r}114 \\
17.6 \%\end{array}$ & & & \\
\hline $\begin{array}{l}\text { No. Sub. Ref in } \\
\text { Case at Closure }\end{array}$ & & & & & 26.555 & 9 & .002 \\
\hline $\begin{array}{l}1 \\
(n=1,464)\end{array}$ & $\begin{array}{r}180 \\
12.3 \%\end{array}$ & $\begin{array}{r}614 \\
41.9 \%\end{array}$ & $\begin{array}{r}380 \\
26 \%\end{array}$ & $\begin{array}{r}290 \\
19.8 \%\end{array}$ & & & \\
\hline $\begin{array}{l}2 \\
(n=556)\end{array}$ & $\begin{array}{r}70 \\
12.6 \%\end{array}$ & $\begin{array}{r}239 \\
43 \%\end{array}$ & $\begin{array}{r}146 \\
26.3 \%\end{array}$ & $\begin{array}{r}101 \\
18.2 \%\end{array}$ & & & \\
\hline $\begin{array}{l}3 \\
(n=199)\end{array}$ & $\begin{array}{r}22 \\
11.1 \%\end{array}$ & $\begin{array}{r}80 \\
40.4 \%\end{array}$ & $\begin{array}{r}65 \\
32.8 \%\end{array}$ & $\begin{array}{r}31 \\
15.7 \%\end{array}$ & & & \\
\hline $\begin{array}{l}\text { Over } 3 \\
(n=304)\end{array}$ & $\begin{array}{r}59 \\
19.4 \%\end{array}$ & $\begin{array}{r}143 \\
47 \%\end{array}$ & $\begin{array}{r}58 \\
19.1 \%\end{array}$ & $\begin{array}{r}44 \\
14.5 \%\end{array}$ & & & \\
\hline Program & & & & & 143.184 & 9 & .000 \\
\hline $\begin{array}{l}\text { Placement } \\
(n=386)\end{array}$ & $\begin{array}{r}68 \\
17.6 \%\end{array}$ & $\begin{array}{r}154 \\
39.9 \%\end{array}$ & $\begin{array}{r}79 \\
20.5 \%\end{array}$ & $\begin{array}{r}85 \\
22 \%\end{array}$ & & & \\
\hline $\begin{array}{l}\text { Neglect } \\
(n=949)\end{array}$ & $\begin{array}{r}81 \\
8.5 \%\end{array}$ & $\begin{array}{r}369 \\
38.9 \%\end{array}$ & $\begin{array}{r}301 \\
31.7 \%\end{array}$ & $\begin{array}{r}198 \\
20.9 \%\end{array}$ & & & \\
\hline $\begin{array}{l}\text { Physical } \\
(n=530)\end{array}$ & $\begin{array}{r}50 \\
9.4 \%\end{array}$ & $\begin{array}{r}219 \\
41.3 \%\end{array}$ & $\begin{array}{r}173 \\
32.6 \%\end{array}$ & $\begin{array}{r}88 \\
16.6 \%\end{array}$ & & & \\
\hline $\begin{array}{l}\text { Other } \\
(n=599)\end{array}$ & $\begin{array}{r}125 \\
20.9 \%\end{array}$ & $\begin{array}{r}310 \\
51.8 \%\end{array}$ & $\begin{array}{r}85 \\
14.2 \%\end{array}$ & $\begin{array}{r}79 \\
13.2 \%\end{array}$ & & & \\
\hline Region & & & & & 123.50 & 45 & .000 \\
\hline $\begin{array}{l}\text { Barren River } \\
(n=157)\end{array}$ & $\begin{array}{r}18 \\
11.5 \%\end{array}$ & $\begin{array}{r}75 \\
47.8 \%\end{array}$ & $\begin{array}{r}33 \\
21 \%\end{array}$ & $\begin{array}{r}31 \\
19.7 \%\end{array}$ & & & \\
\hline $\begin{array}{l}\text { Big Sandy } \\
(n=77)\end{array}$ & $\begin{array}{r}10 \\
12.8 \%\end{array}$ & $\begin{array}{r}29 \\
37.2 \%\end{array}$ & $\begin{array}{r}20 \\
25.6 \%\end{array}$ & $\begin{array}{r}19 \\
24.4 \%\end{array}$ & & & \\
\hline $\begin{array}{l}\text { Bluegrass/Fayette } \\
(n=94)\end{array}$ & $\begin{array}{r}23 \\
24.2 \%\end{array}$ & $\begin{array}{r}38 \\
40 \%\end{array}$ & $\begin{array}{r}18 \\
19 . .8 \%\end{array}$ & $\begin{array}{r}16 \\
16.8 \%\end{array}$ & & & \\
\hline
\end{tabular}


Table 20 (Continued)

Results of Chi-Square Testing: Case Characteristics by Change in Mudd Safety CQA Rating, Opening to Closing

\begin{tabular}{|c|c|c|c|c|c|c|c|}
\hline \multirow[t]{2}{*}{$\begin{array}{l}\text { Case } \\
\text { Characteristics }\end{array}$} & \multicolumn{4}{|c|}{$\begin{array}{l}\text { Mudd Safety Reduction Between } \\
\text { Opening and Closing }\end{array}$} & \multirow[t]{2}{*}{$\begin{array}{l}\text { Chi- } \\
\text { Square }\end{array}$} & \multirow[t]{2}{*}{$d f$} & \multirow[t]{2}{*}{ Sig. } \\
\hline & $\begin{array}{c}\text { Lowest- } \\
0\end{array}$ & $1-6$ & $7-10$ & $11-16$ & & & \\
\hline \multicolumn{8}{|l|}{ Region Cont. } \\
\hline $\begin{array}{l}\text { Bluegrass Rural } \\
(n=321)\end{array}$ & $\begin{array}{r}55 \\
17 \%\end{array}$ & $\begin{array}{r}151 \\
46.7 \%\end{array}$ & $\begin{array}{r}70 \\
10.8 \%\end{array}$ & $\begin{array}{r}47 \\
14.6 \%\end{array}$ & & & \\
\hline $\begin{array}{l}\text { Cumberland Valley } \\
(n=167)\end{array}$ & $\begin{array}{r}18 \\
10.4 \% \\
\end{array}$ & $\begin{array}{r}48 \\
27.7 \% \\
\end{array}$ & $\begin{array}{r}46 \\
26.6 \% \\
\end{array}$ & $\begin{array}{r}61 \\
35.3 \% \\
\end{array}$ & & & \\
\hline $\begin{array}{l}\text { Fivco } \\
(n=83)\end{array}$ & $\begin{array}{r}10 \\
11.8 \% \\
\end{array}$ & $\begin{array}{r}19 \\
22.4 \% \\
\end{array}$ & $\begin{array}{r}32 \\
37.6 \% \\
\end{array}$ & $\begin{array}{r}24 \\
28.2 \% \\
\end{array}$ & & & \\
\hline $\begin{array}{l}\text { Gateway/Buffalo } \\
(n=111)\end{array}$ & $\begin{array}{r}18 \\
15 \% \\
\end{array}$ & $\begin{array}{r}59 \\
49.2 \% \\
\end{array}$ & $\begin{array}{r}27 \\
22.5 \% \\
\end{array}$ & $\begin{array}{r}16 \\
13.3 \% \\
\end{array}$ & & & \\
\hline $\begin{array}{l}\text { Green River } \\
(n=167)\end{array}$ & $\begin{array}{r}18 \\
10.7 \% \\
\end{array}$ & $\begin{array}{r}83 \\
49.1 \%\end{array}$ & $\begin{array}{r}44 \\
26 \%\end{array}$ & $\begin{array}{r}24 \\
14.2 \%\end{array}$ & & & \\
\hline $\begin{array}{l}\text { Kentucky River } \\
(n=100)\end{array}$ & $\begin{array}{r}14 \\
14.3 \% \\
\end{array}$ & $\begin{array}{r}30 \\
30.6 \% \\
\end{array}$ & $\begin{array}{r}26 \\
26.5 \% \\
\end{array}$ & $\begin{array}{r}28 \\
28.6 \% \\
\end{array}$ & & & \\
\hline $\begin{array}{l}\text { KIPDA/Jefferson } \\
(n=453)\end{array}$ & $\begin{array}{r}41 \\
8.6 \% \\
\end{array}$ & $\begin{array}{r}214 \\
44.7 \% \\
\end{array}$ & $\begin{array}{r}147 \\
30.7 \% \\
\end{array}$ & $\begin{array}{r}77 \\
16.1 \% \\
\end{array}$ & & & \\
\hline $\begin{array}{l}\text { KIPDA/Rural } \\
(n=63)\end{array}$ & $\begin{array}{r}8 \\
2.4 \% \\
\end{array}$ & $\begin{array}{r}24 \\
39.3 \% \\
\end{array}$ & $\begin{array}{r}16 \\
26.2 \% \\
\end{array}$ & $\begin{array}{r}13 \\
21.3 \% \\
\end{array}$ & & & \\
\hline $\begin{array}{l}\text { Lake Cumberland } \\
(n=126)\end{array}$ & $\begin{array}{r}16 \\
12.1 \% \\
\end{array}$ & $\begin{array}{r}53 \\
40.2 \% \\
\end{array}$ & $\begin{array}{r}34 \\
25.8 \% \\
\end{array}$ & $\begin{array}{r}29 \\
22 \%\end{array}$ & & & \\
\hline $\begin{array}{l}\text { Lincoln Trail } \\
(n=149)\end{array}$ & $\begin{array}{r}26 \\
17 \% \\
\end{array}$ & $\begin{array}{r}70 \\
45.8 \% \\
\end{array}$ & $\begin{array}{r}34 \\
22.2 \% \\
\end{array}$ & $\begin{array}{r}23 \\
15 \% \\
\end{array}$ & & & \\
\hline $\begin{array}{l}\text { Northern KY } \\
(n=236)\end{array}$ & $\begin{array}{r}34 \\
14.2 \% \\
\end{array}$ & $\begin{array}{r}113 \\
47.3 \% \\
\end{array}$ & $\begin{array}{r}56 \\
23.4 \% \\
\end{array}$ & $\begin{array}{r}36 \\
15.1 \% \\
\end{array}$ & & & \\
\hline $\begin{array}{l}\text { Pennyrile } \\
(n=110)\end{array}$ & $\begin{array}{r}17 \\
15.2 \% \\
\end{array}$ & $\begin{array}{r}46 \\
41.1 \% \\
\end{array}$ & $\begin{array}{r}32 \\
28.6 \% \\
\end{array}$ & $\begin{array}{r}17 \\
15.2 \%\end{array}$ & & & \\
\hline $\begin{array}{l}\text { Purchase } \\
(n=51)\end{array}$ & $\begin{array}{r}5 \\
10.4 \%\end{array}$ & $\begin{array}{r}24 \\
50 \%\end{array}$ & $\begin{array}{r}14 \\
29.2 \%\end{array}$ & $\begin{array}{r}5 \\
10.4 \%\end{array}$ & & & \\
\hline
\end{tabular}

Of the nominal/ordinal variables examined, primary program of service, a prior episode of treatment, supervisor's gender, all CQA individual risk fields, and number of referrals in case at closure were significantly related to the CQA cumulative rating at closure (rating by level of risk) (Table 18). Of cases having prior agency involvement, $19.5 \%$ were rated as moderate to high risk, while 
cases without agency involvement had only $15 \%$ of their scores rated as moderate to high risk. Even though the overall mean for cases with male supervisors (4.04) was only slightly higher than for females (3.58) on the closing CQA cumulative scores, $4.4 \%$ of the scores of the cases with male supervisors were in the significant and high risk categories at closure, while those with female supervisors had only $2.7 \%$ of the cases in the significant and high risk categories. Cases with over 3 referrals at time of case closure had the highest percentage $(22.7 \%)$ of cases scoring in the moderate to high-risk categories at time of case closure. Accordingly, cases with only 1 referral in them at case closure had the lowest percentage (14.8\%) of cases scoring in the moderate to high-risk categories at time of case closure. Supervisor area of study was close to having a significant relationship ( $p$.067). Geographic region, worker gender, worker area of study, worker and supervisor highest degree, worker and supervisor years of service, worker position, and current case plan were not significantly related to the closing cumulative CQA score (Table 18).

Variables found to be associated with reduction in cumulative CQA score were: (a) region, (b) geographic region, (c) all CQA risk fields, (d) primary program of study, (e) supervisor gender, and (f) supervisor area of study (Table 19). Higher levels of change (over 7 points) were found in physical abuse cases, with $57 \%$ of the cases showing more than 7 points of change, followed by neglect with $54 \%$ of the cases showing more than 7 points of change. Caution must however, be taken in considering these findings as programs of service were not mutually exclusive. Workers selected the primary program of service for their 
cases based on existing maltreatment; however, it is probable that many of the cases had more than one program of service during the life of the case. More cases with a female supervisor (49.9\%) had at least 7 points of reduction in the cumulative CQA score from opening to closing, than those with a male supervisor $(45.1 \%)$.

Variables found to have no significant relationship to reduction in CQA score were: (a) case having prior treatment episode, (b) worker gender, (c) supervisor and worker highest degree, (d) number of referrals in case at closure, (e) worker area of study, and (f) time case was open for current treatment episode (Table 19). When CQA change was examined in 5 levels by dividing the most change into (a) 15-21 and (b) 21-28, supervisor's degree (bachelor or masters) was significant at $p<.03$.

The variables having a relationship to reduction in clients' CQA safety risk ratings from the opening CQA to the closing CQA were: (a) worker position, (b) supervisor area of study, (c) supervisor degree, (d) supervisor gender, (e) workers years of experience, (f) worker gender, (h) geographic region, (i) region, (j) number of referrals in case at closure, and (k) primary program of service. Variables not having a significant relationship included, worker degree, worker area of study, worker gender, and supervisor years of service (Table 20).

Geographic region was found to have a significant relationship to CQA change and safety change. Surprisingly, the highest percentage (57.1\%) of cases scoring over 7 points of CQA reduction was in those regions classified as Appalachia. Regions with rural areas had the second highest percentage 
(46.3\%) of cases scoring over 7 points of CQA change, followed by urban areas with the lowest percentage (44.8\%).

In summary, the variables having a relationship to reduction in level of risk from the first CQA at case opening to the last CQA at case closure were (a) region, (b) primary program of service, (c) a prior treatment episode, (d) individual CQA risk domains scores of the first CQA, (e) supervisor highest degree, $(f)$ case manager area of study, $(g)$ case manager position, (h) supervisor gender, (i) number of referrals in case at closure (j) worker position and $(k)$ worker gender. Regions, primary programs of service and individual risk domains have been explored under Change. Prior treatment episode and number of referrals will be explored under Recurrent Maltreatment. Variables related to worker demographics will be explored more fully under Case Manager Demographics.

Repeat Maltreatment: Research Questions Two and Three

Research Question 2: What is the relationship between the levels of risk as assessed by the CQA and repeat maltreatment for child protective service cases following case closure?

Research Question 3: What are the relationships between services provided by the Kentucky Department of Protection and Permanency and repeat maltreatment following case closure? Cases with Prior Treatment Episode

One out of every two cases in this study had previously received services from CFC. Of the 2,829 cases in the study population, 1,435 cases had had a 
previous referral (Table 21). The mean length of time between the last case closing and the current case opening was 10.70 months. The shortest means between the previous case closure and the current case opening were in Green River region ( 8.5 months) and Cumberland Valley region ( 8.55 months). The longest mean time between the prior case closure and current treatment episode was in the KIPDA Rural region (13.6 months). Considering that Cumberland Valley and KIPDA Rural regions had the higher CQA change means (greatest reduction in risk) and shortest service times (Table 14), it is interesting that the time between case closure and reopening was vastly different between the two regions. KIPDA Rural, having one of the highest rates of change (greater reduction in risk) and the shortest service times, was able to maintain the case without repeat maltreatment for a longer period of time.

Recidivism rates ranged from a low of $34 \%$ in the KIPDA Rural region to a high of $59 \%$ in the KIPDA Jefferson region. Regions exceeding $50 \%$ recidivism included, Barren River, Big Sandy, KIPDA Jefferson, Kentucky River, Lincoln Trail, and Pennryrile. The mean length of time the cases were open during the previous treatment episode was 15.86 months (Table 21). Longer service times were found in the Barren River, Big Sandy, KIPDA Jefferson, and Kentucky River regions. Pennyrile (11.35 months) and Purchase (11.55 months) were well below the mean for service time (15.86 months).

The number of referrals in the study, including reports from prior treatment episodes, ranged from 1 to 19 at case closure (Table 22). Although one case had 19 referrals, only 4 of those referrals were substantiated or found to be in 
Table 21

Distribution of Cases with Prior Treatment Episode, Means of Months that

Cases Were Previously Open and Means of Months Between Case Closing

and Reopening $(N=1,435)$

\begin{tabular}{|c|c|c|c|c|c|c|}
\hline Region & $\begin{array}{c}\text { Mean } \\
\text { Months Between } \\
\text { Case Closing } \\
\text { and Reopening }\end{array}$ & SD & $\begin{array}{l}\text { Number of } \\
\text { Cases with a } \\
\text { Prior } \\
\text { Treatment } \\
\text { Episode }\end{array}$ & $\begin{array}{l}\text { Percentage } \\
\text { Study } \\
\text { Population } \\
\text { Within } \\
\text { Region }\end{array}$ & $\begin{array}{l}\text { Mean } \\
\text { Months } \\
\text { Case } \\
\text { Previously } \\
\text { Open }\end{array}$ & $\overline{S D}$ \\
\hline KIPDA Rural & 13.60 & 13.2 & 25 & 34 & 14.42 & 15.3 \\
\hline Lake Cumberland & 12.72 & 14.3 & 68 & 47 & 13.69 & 14.6 \\
\hline Bluegrass Fayette & 12.22 & 10.7 & 55 & 45 & 15.60 & 16.1 \\
\hline $\begin{array}{l}\text { Gateway/Buffalo } \\
\text { Trace }\end{array}$ & 11.95 & 13.1 & 66 & 50 & 16.79 & 16.7 \\
\hline Pennyrile & 11.82 & 10.1 & 66 & 52 & 11.35 & 11.5 \\
\hline $\begin{array}{l}\text { Northern } \\
\text { Kentucky }\end{array}$ & 11.60 & 12.0 & 139 & 50 & 15.23 & 14.6 \\
\hline Barren River & 11.12 & 11.9 & 99 & 58 & 18.30 & 18.1 \\
\hline KIPDA Jefferson & 10.83 & 11.7 & 308 & 59 & 17.00 & 15.9 \\
\hline Purchase & 10.81 & 9.3 & 29 & 48 & 11.55 & 12.9 \\
\hline Kentucky River & 10.80 & 10.3 & 57 & 54 & 18.90 & 16.5 \\
\hline Bluegrass Rural & 10.28 & 13.4 & 172 & 46 & 16.52 & 14.8 \\
\hline Lincoln Trail & 9.71 & 10.4 & 94 & 56 & 13.74 & 14.3 \\
\hline Fivco & 9.48 & 12.7 & 45 & 48 & 15.21 & 14.1 \\
\hline Big Sandy & 9.11 & 10.5 & 50 & 56 & 17.60 & 17.0 \\
\hline $\begin{array}{l}\text { Cumberland } \\
\text { Valley }\end{array}$ & 8.55 & 9.8 & 84 & 44 & 15.45 & 16.5 \\
\hline Green River & 8.50 & 9.7 & 79 & 44 & 14.96 & 13.3 \\
\hline $\begin{array}{l}\text { Overall } \\
\text { Mean/Total }\end{array}$ & 10.70 & 11.7 & 1,436 & 49 & 15.86 & 15.4 \\
\hline
\end{tabular}

need of services. Five hundred and fifty-eight cases had 5 or more referrals, with

58 cases having 5 or more referrals substantiated or found in need of services. 


\section{Table 22}

\section{Frequency of Referrals in Cases at Closure*}

\begin{tabular}{|c|c|c|c|c|c|c|c|c|c|c|c|c|}
\hline Total Number & Numb & of $S$ & ubstar & tiated & $r \ln 1$ & eed & $\overline{f R e}$ & erra & $\operatorname{inc}$ & & & \\
\hline & 1 & 2 & 3 & 4 & 5 & 6 & 7 & 8 & 10 & 13 & Incomplete & $\begin{array}{c}\text { Total } \\
\text { Number } \\
\text { Referrals }\end{array}$ \\
\hline One & 803 & & & & & & & & & & 10 & 813 \\
\hline Two & 407 & 197 & & & & & & & & & 26 & 827 \\
\hline Three & 195 & 163 & 62 & & & & & & & & 15 & 722 \\
\hline Four & 87 & 104 & 52 & 11 & & & & & & & 16 & 511 \\
\hline Five & 63 & 62 & 47 & 18 & 1 & & & & & & 11 & 416 \\
\hline Six & 34 & 41 & 24 & 20 & 8 & 1 & & & & & 12 & 326 \\
\hline Seven & 13 & 25 & 17 & 13 & 4 & 2 & & & & & 9 & 207 \\
\hline Eight & 8 & 15 & 12 & 14 & 8 & 4 & 1 & 1 & & & 4 & 213 \\
\hline Nine & 4 & 6 & 10 & 8 & 4 & 1 & 3 & & & & 2 & 127 \\
\hline Ten & 3 & 6 & 3 & 5 & 4 & 1 & 1 & & & & 4 & 81 \\
\hline Eleven & 2 & 4 & 1 & 4 & 1 & 3 & & 1 & & & & 60 \\
\hline Twelve & 2 & 3 & 2 & 3 & & 1 & & & & & 1 & 33 \\
\hline Thirteen & & 1 & 1 & 1 & 1 & & & & & & & 14 \\
\hline Fourteen & & 1 & & 1 & 1 & 2 & & & & & 1 & 23 \\
\hline Fifteen & & & & 2 & & 1 & & 1 & 1 & 1 & & 45 \\
\hline Nineteen & & & & 1 & & & & & & & & 4 \\
\hline Total & 1,621 & 628 & 232 & 101 & 32 & 16 & 5 & 3 & 1 & 1 & 111 & 4,022 \\
\hline
\end{tabular}

${ }^{\star}$ Closure occurring between January 2002 and June 2002.

There was a total of 4,022 referrals with substantiated or found in need of services findings. This study involved only cases that were open for ongoing 
services. Therefore, referrals that were unsubstantiated, without case opening, were not reflected in these numbers. Some case histories may have begun prior to 1997; however, the computerization of case records limits their availability for analyses.

\section{Referrals Since Case Closure}

From the time of the most recent case closure through June 2003, 758 cases had new referrals. In the 758 cases, there were a total of 1,117 new referrals. Since closure, 300 cases have had at least one substantiated or found in need of services finding, with 50 cases having had multiple substantiated referrals (Table 23).

\section{Table 23}

\section{Frequency of Referrals in Cases Since Case Closure}

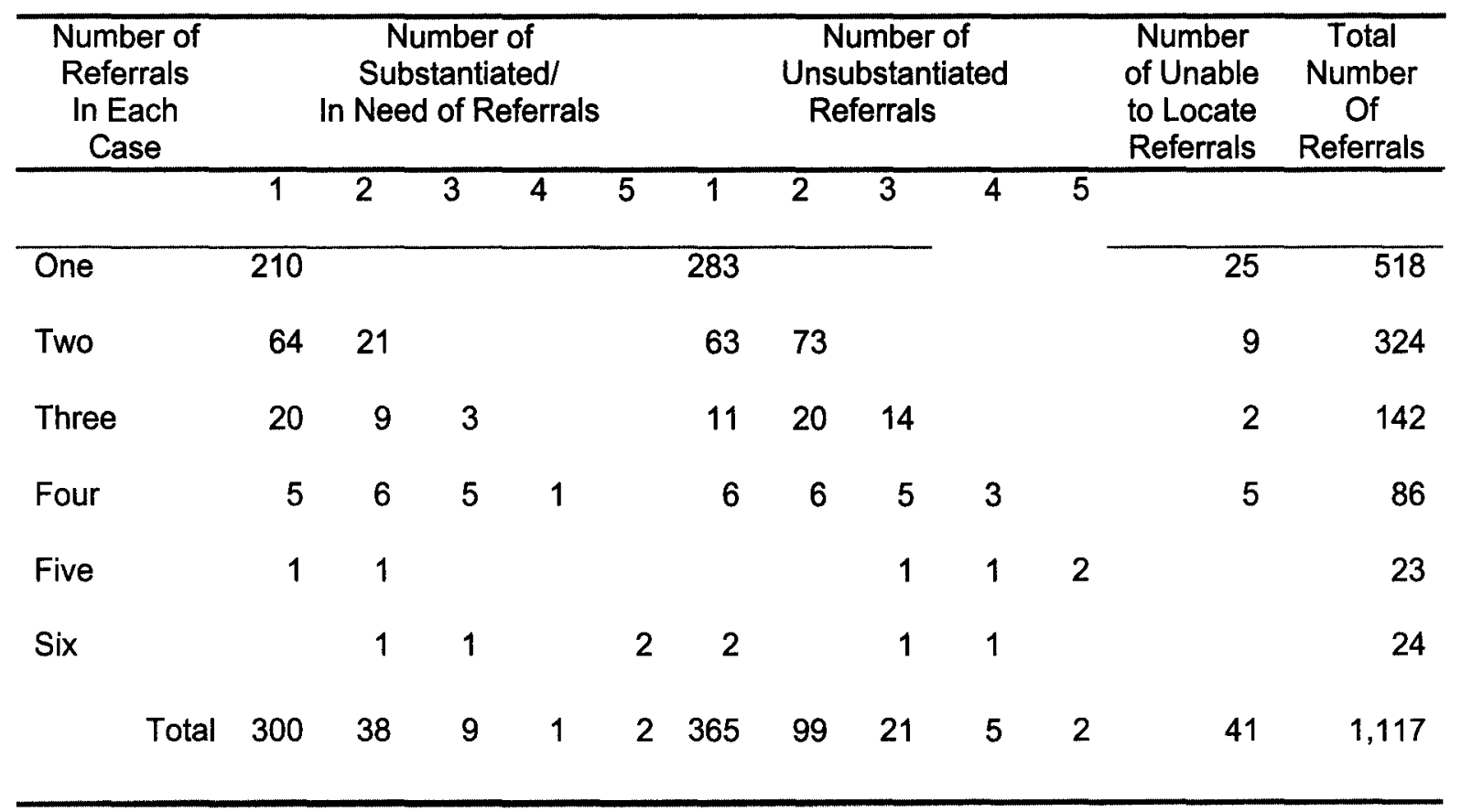


The number of new referrals in the cases ranged from 1 to 6 , with 2 cases having 5 substantiated/found in need of services referrals and 2 cases having 5 unsubstantiated referrals. Four hundred and ninety-two cases had unsubstantiated referrals, with 127 cases having multiple unsubstantiated referrals. Forty-one cases had family could not be located as a referral finding.

Slightly more than one-fourth of the study cases had at least one report of maltreatment following case closure, with $12 \%$ of the cases having a substantiated or family in need of services finding (Table 24). The overall mean months between case closure and new referral was 6.4 months. The Lake Cumberland region (7.7 months) and Gateway/Buffalo Trace region (7.2 months) had the most mean months between case closure and new referrals. While the shortest time between case closure and new referral was found in the Fivco region (5 months). The Cumberland Valley, KIPDA Rural, Lincoln Trail, and Northern Kentucky regions were below the State's mean for length of time between case closure and new referral. The number of referrals received on the closed cases rose sharply 90 days following case closure and then declined slowly from 4 to 10 months (Figure 6). The sharp increase of referrals within 90 days of case closure would suggest that additional support and service coordination are needed in aftercare planning.

The number of children involved in the new referrals ranged from 1 to 7 in each incident (Figure 7). One thousand five hundred and twenty-eight children were involved in the new referrals. Approximately $22 \%$ of the children were age 3 or under, $48 \%$ were under the age of 8 , and $27 \%$ were over the age of 12 . The 
child victims were evenly divided between males and females, with $49 \%$ of the child victims being female.

\section{Table 24}

\section{Distribution of Cases with Recidivism by Region}

\begin{tabular}{|c|c|c|c|c|c|c|}
\hline Region & $\begin{array}{c}\text { Frequency } \\
\text { of } \\
\text { Closed } \\
\text { Cases } \\
\text { In study }\end{array}$ & $\begin{array}{l}\text { Mean of Length } \\
\text { of Time in } \\
\text { Months from } \\
\text { Case Closure to } \\
\text { First New } \\
\text { Referral }\end{array}$ & $\begin{array}{l}\text { Frequency of } \\
\text { All Cases } \\
\text { with } \\
\text { New Reports } \\
\text { Following } \\
\text { Closure }\end{array}$ & $\begin{array}{l}\text { Percentage } \\
\text { of Cases in } \\
\text { Study with } \\
\text { New } \\
\text { Reports } \\
\text { Following } \\
\text { Closure }\end{array}$ & $\begin{array}{l}\text { Frequency of } \\
\text { Cases in } \\
\text { Study with } \\
\text { Substantiated } \\
\text { Referrals } \\
\text { Since } \\
\text { Closure* }\end{array}$ & $\begin{array}{l}\text { Percentage } \\
\text { of Cases in } \\
\text { Study with } \\
\text { Substantiated } \\
\text { Referrals } \\
\text { Since } \\
\text { Closure }\end{array}$ \\
\hline Barren River & 172 & 6.4 & 50 & 29.0 & 26 & 15.1 \\
\hline Big Sandy & 90 & 6.7 & 26 & 28.8 & 10 & 11 \\
\hline Bluegrass Fayette & 122 & 7.0 & 35 & 28.7 & 14 & 11.4 \\
\hline Bluegrass Rural & 377 & 6.8 & 91 & 24.1 & 33 & 8.7 \\
\hline Cumberland Valley & 190 & 5.9 & 33 & 17.3 & 23 & 12.1 \\
\hline Fivco & 93 & 5.0 & 24 & 25.8 & 17 & 18.3 \\
\hline $\begin{array}{l}\text { Gateway/Buffalo } \\
\text { Trace }\end{array}$ & 131 & 7.2 & 36 & 27.5 & 12 & 9.1 \\
\hline Green River & 178 & 6.6 & 55 & 30.9 & 28 & 15.7 \\
\hline Kentucky River & 105 & 6.7 & 30 & 28.6 & 17 & 16.2 \\
\hline KIPDA Jefferson & 523 & 6.5 & 158 & 30.2 & 78 & 14.9 \\
\hline KIPDA Rural & 72 & 5.2 & 16 & 22.2 & 7 & 10 \\
\hline Lake Cumberland & 145 & 7.7 & 35 & 24.1 & 18 & 12.4 \\
\hline Lincoln Trail & 168 & 5.6 & 52 & 31.0 & 21 & 12.5 \\
\hline Northern Kentucky & 277 & 6.0 & 82 & 29.6 & 28 & 10.1 \\
\hline Pennyrile & 126 & 6.8 & 21 & 16.7 & 9 & 7.1 \\
\hline Purchase & 60 & 6.5 & 14 & 23.3 & 9 & 15 \\
\hline $\begin{array}{l}\text { Overall } \\
\text { Means/Totals }\end{array}$ & 2,898 & 6.4 & 758 & 26.2 & 350 & 12 \\
\hline
\end{tabular}




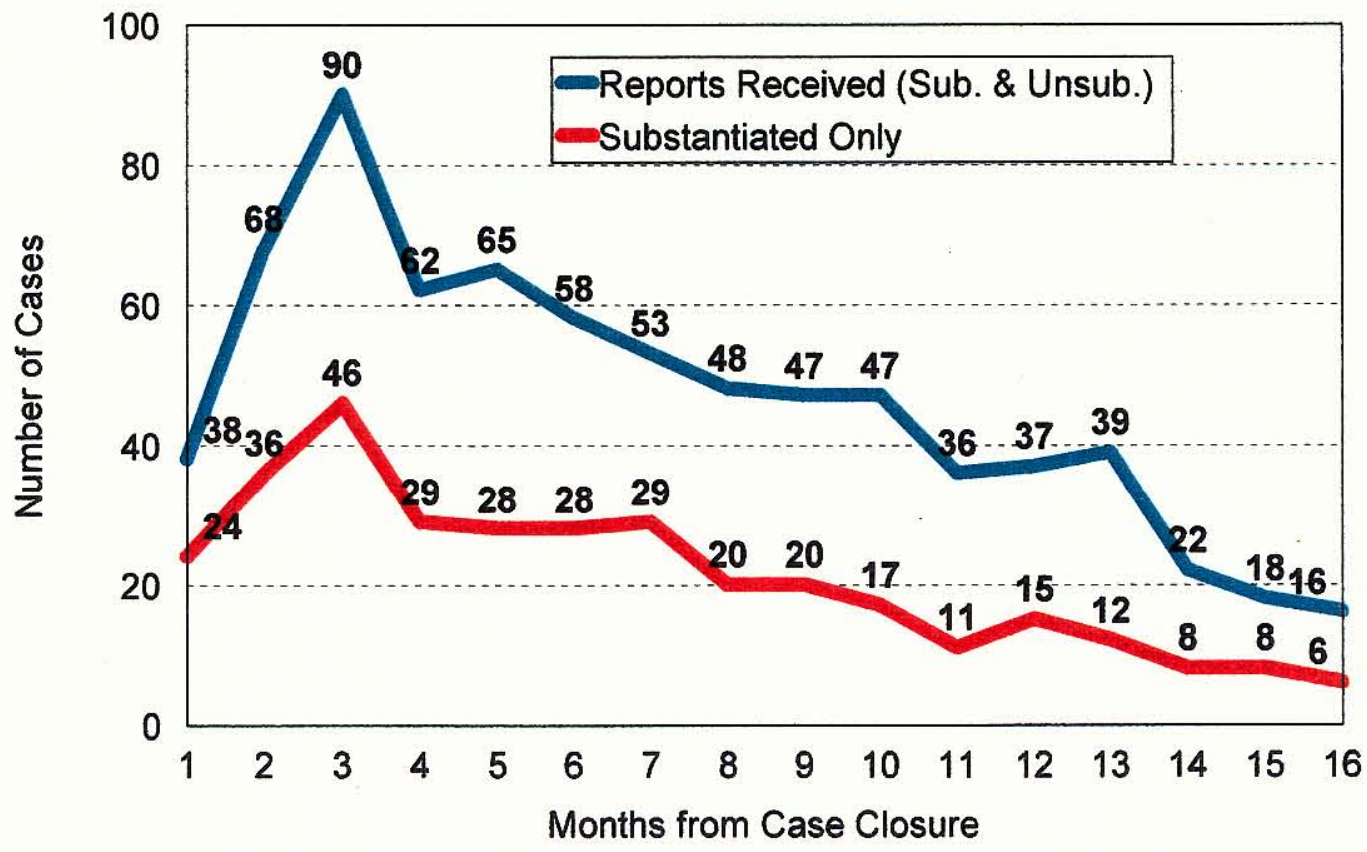

Figure 6. Length of time from case closure to new referrals.

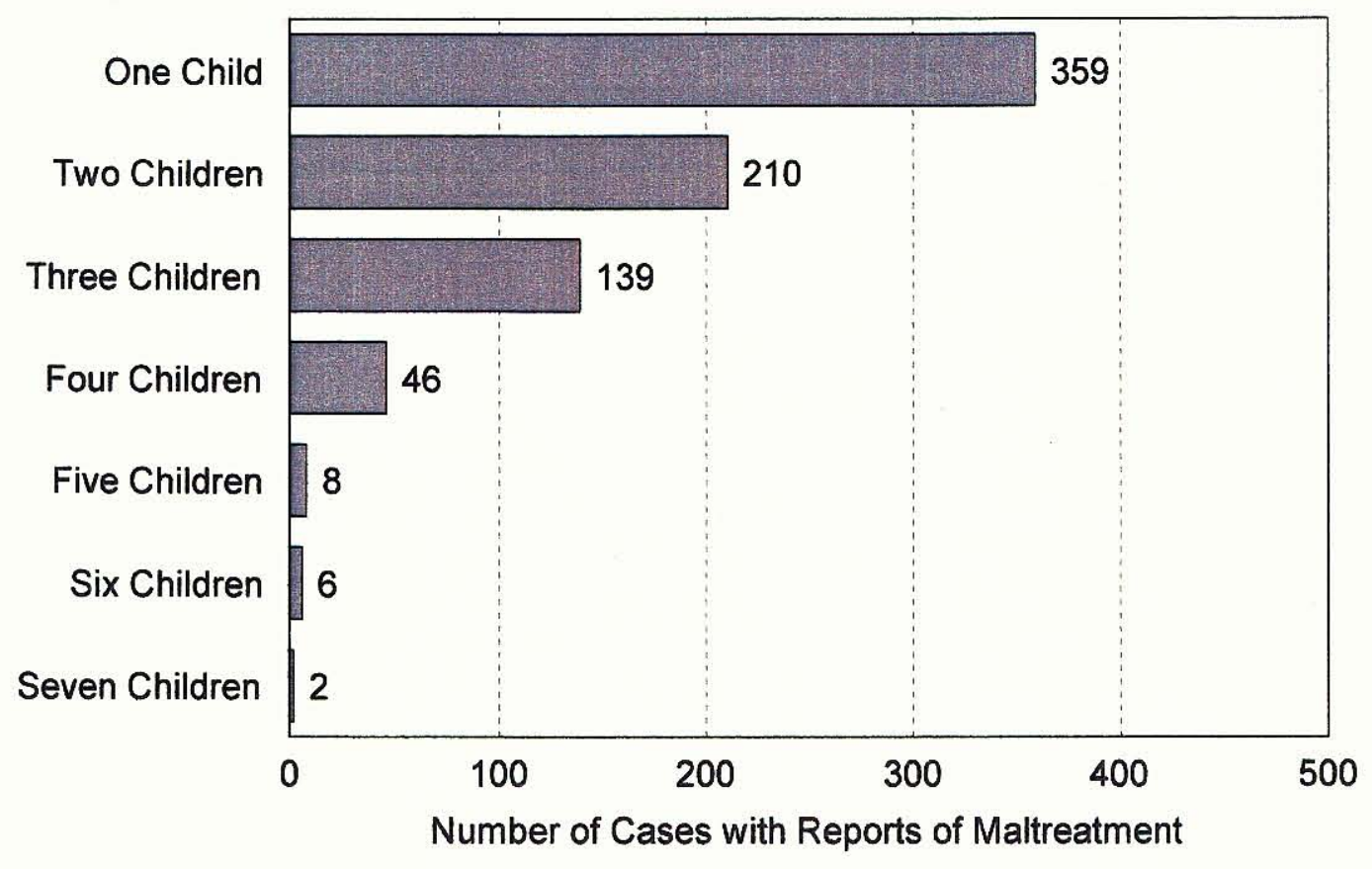

Figure 7. Number of children involved in reports of maltreatment since closure by case. 


\section{Results of Chi-Square testing}

Bivariate analysis was used to examine relationships and differences in case variables and recurrent maltreatment. Case characteristics by substantiated maltreatment (Table 25) presents case variables with an association to substantiated maltreatment following case closure. Case characteristics by cases with reports of maltreatment (Table 26) presents case variables with an association to substantiated and/or unsubstantiated maltreatment following case closure. English, Marshall, Brummel, and Coghlan (1998) supported the inclusion of unsubstantiated referrals in studies of recurrent maltreatment.

\section{Restatement of and Answers to Questions Two and Three}

Research questions 2 and 3 were answered by examining repeat maltreatment in two ways: (a) substantiated referrals following case closure (Table 25), and (b) reports of maltreatment received following case closure, including substantiated and unsubstantiated findings (Table 26).

Research Question 2: What is the relationship between the levels of risk as assessed by the CQA and repeat maltreatment for child protective service cases following case closure?

Significant relationships were found between reports of maltreatment following case closure and (a) opening cumulative CQA scores, (b) closing cumulative CQA scores, (c) opening Mudd safety scores, and (d) closing Mudd safety scores. Only $23 \%$ of those having the lowest CQA scores at opening (0-6) had at least one new report of maltreatment following case closure, while $29 \%$ of 
Table 25

Results of Chi-Square Testing: Case Characteristics by Repeat

Substantiated Maltreatment

\begin{tabular}{|c|c|c|c|c|c|}
\hline \multirow[t]{2}{*}{$\begin{array}{l}\text { Case } \\
\text { Characteristics }\end{array}$} & \multicolumn{2}{|c|}{$\begin{array}{l}\text { Substantiated Referrals } \\
\text { After Case Closure }\end{array}$} & \multirow[t]{2}{*}{$\begin{array}{l}\text { Chi- } \\
\text { Square }\end{array}$} & \multirow[t]{2}{*}{$d f$} & \multirow[t]{2}{*}{ Sig. } \\
\hline & Yes & No & & & \\
\hline $\begin{array}{l}\text { Mudd Safety } \\
\text { Factor at Close }\end{array}$ & & & 12.382 & 4 & .015 \\
\hline $\begin{array}{l}O \\
(n=931)\end{array}$ & $\begin{array}{r}104 \\
11.2 \%\end{array}$ & $\begin{array}{r}827 \\
88.8 \%\end{array}$ & & & \\
\hline $\begin{array}{l}1-4 \\
(n=1,226)\end{array}$ & $\begin{array}{r}189 \\
15.4 \% \\
\end{array}$ & $\begin{array}{r}1,037 \\
84.6 \% \\
\end{array}$ & & & \\
\hline $\begin{array}{l}5-8 \\
(n=311)\end{array}$ & $\begin{array}{r}31 \\
10 \%\end{array}$ & $\begin{array}{r}280 \\
90 \%\end{array}$ & & & \\
\hline $\begin{array}{l}9-12 \\
(n=35)\end{array}$ & $\begin{array}{r}4 \\
11.4 \% \\
\end{array}$ & $\begin{array}{r}31 \\
88.6 \%\end{array}$ & & & \\
\hline $\begin{array}{l}13-16 \\
(n=81)\end{array}$ & $\begin{array}{r}8 \\
9.9 \% \\
\end{array}$ & $\begin{array}{r}73 \\
90.1 \% \\
\end{array}$ & & & \\
\hline $\begin{array}{l}\text { Sub.Referrals in } \\
\text { Case at Closure }\end{array}$ & & & 10.880 & 3 & .012 \\
\hline $\begin{array}{l}1 \\
(n=1,621)\end{array}$ & $\begin{array}{r}172 \\
10.6 \% \\
\end{array}$ & $\begin{array}{r}1,449 \\
89.4 \% \\
\end{array}$ & & & \\
\hline $\begin{array}{l}2 \\
(n=628)\end{array}$ & $\begin{array}{r}92 \\
14.6 \% \\
\end{array}$ & $\begin{array}{r}536 \\
85.4 \% \\
\end{array}$ & & & \\
\hline $\begin{array}{l}3 \\
(n=232)\end{array}$ & $\begin{array}{r}34 \\
14.7 \% \\
\end{array}$ & $\begin{array}{r}198 \\
85.3 \% \\
\end{array}$ & & & \\
\hline $\begin{array}{l}\text { Over } 3 \\
(n=348)\end{array}$ & $\begin{array}{r}52 \\
14.9 \% \\
\end{array}$ & $\begin{array}{r}296 \\
85.1 \% \\
\end{array}$ & & & \\
\hline $\begin{array}{l}\text { Risk Fields At } \\
\text { Opening }\end{array}$ & & & & & \\
\hline $\begin{array}{l}\text { Sequence of } \\
\text { Events }\end{array}$ & & & 9.911 & 4 & .042 \\
\hline $\begin{array}{l}(0) \\
(n=412)\end{array}$ & $\begin{array}{r}45 \\
10.9 \% \\
\end{array}$ & $\begin{array}{r}367 \\
89.1 \% \\
\end{array}$ & & & \\
\hline $\begin{array}{l}(1) \\
(n=452)\end{array}$ & $\begin{array}{r}46 \\
10.2 \% \\
\end{array}$ & $\begin{array}{r}4-6 \\
89.8 \% \\
\end{array}$ & & & \\
\hline $\begin{array}{l}(2) \\
(n=888)\end{array}$ & $\begin{array}{r}134 \\
15.1 \% \\
\end{array}$ & $\begin{array}{r}754 \\
84.9 \% \\
\end{array}$ & & & \\
\hline $\begin{array}{l}(3) \\
(n=746)\end{array}$ & $\begin{array}{r}90 \\
12.1 \% \\
\end{array}$ & $\begin{array}{r}656 \\
87.9 \%\end{array}$ & & & \\
\hline $\begin{array}{l}(4) \\
(n=331)\end{array}$ & $\begin{array}{r}35 \\
10.6 \% \\
\end{array}$ & $\begin{array}{r}296 \\
89.4 \% \\
\end{array}$ & & & \\
\hline Family Devel. & & & 11.793 & 4 & .019 \\
\hline $\begin{array}{l}(0) \\
(n=361)\end{array}$ & $\begin{array}{r}30 \\
8.3 \% \\
\end{array}$ & $\begin{array}{r}331 \\
91.7 \% \\
\end{array}$ & & & \\
\hline
\end{tabular}


Table 25 (Continued)

Results of Chi-Square Testing: Case Characteristics by Repeat

Substantiated Maltreatment

\begin{tabular}{|c|c|c|c|c|c|}
\hline \multirow[t]{2}{*}{$\begin{array}{l}\text { Case } \\
\text { Characteristics }\end{array}$} & \multicolumn{2}{|c|}{$\begin{array}{c}\text { Substantiated Referrals } \\
\text { After Case Closure }\end{array}$} & \multirow[t]{2}{*}{$\begin{array}{l}\text { Chi- } \\
\text { Square }\end{array}$} & \multirow[t]{2}{*}{$d f$} & \multirow[t]{2}{*}{ Sig. } \\
\hline & Yes & No & & & \\
\hline \multicolumn{6}{|l|}{ Family Dev. (Cont) } \\
\hline $\begin{array}{l}(1) \\
(n=784)\end{array}$ & $\begin{array}{r}102 \\
30.6 \% \\
\end{array}$ & $\begin{array}{r}682 \\
87 \% \\
\end{array}$ & & & \\
\hline $\begin{array}{l}(2) \\
(n=630)\end{array}$ & $\begin{array}{r}96 \\
15.2 \% \\
\end{array}$ & $\begin{array}{r}534 \\
84.8 \% \\
\end{array}$ & & & \\
\hline $\begin{array}{l}(3) \\
(n=517)\end{array}$ & $\begin{array}{r}56 \\
10.8 \% \\
\end{array}$ & $\begin{array}{r}461 \\
89.2 \% \\
\end{array}$ & & & \\
\hline $\begin{array}{l}(4) \\
(n=410)\end{array}$ & $\begin{array}{r}49 \\
12 \%\end{array}$ & $\begin{array}{r}361 \\
88 \%\end{array}$ & & & \\
\hline Family Support & & & 9.345 & 4 & .053 \\
\hline $\begin{array}{l}(0) \\
(n=1,406)\end{array}$ & $\begin{array}{r}153 \\
10.9 \% \\
\end{array}$ & $\begin{array}{r}1,253 \\
89.1 \% \\
\end{array}$ & & & \\
\hline $\begin{array}{l}(1) \\
(n=673)\end{array}$ & $\begin{array}{r}101 \\
15 \%\end{array}$ & $\begin{array}{r}572 \\
85 \%\end{array}$ & & & \\
\hline $\begin{array}{l}(2) \\
(n=476)\end{array}$ & $\begin{array}{r}63 \\
13.2 \%\end{array}$ & $\begin{array}{r}413 \\
86.8 \%\end{array}$ & & & \\
\hline $\begin{array}{l}(3) \\
(n=128)\end{array}$ & $\begin{array}{r}11 \\
8.6 \%\end{array}$ & $\begin{array}{r}117 \\
91.4 \%\end{array}$ & & & \\
\hline $\begin{array}{l}(4) \\
(n=72)\end{array}$ & $\begin{array}{r}336 \\
12.2 \% \\
\end{array}$ & $\begin{array}{r}64 \\
88.9 \% \\
\end{array}$ & & & \\
\hline \multicolumn{6}{|l|}{$\begin{array}{l}\text { Risk Fields at } \\
\text { Closing } \\
\end{array}$} \\
\hline $\begin{array}{l}\text { Sequence of } \\
\text { Events }\end{array}$ & & & 7.811 & 4 & .099 \\
\hline $\begin{array}{l}(0) \\
(n=2,072)\end{array}$ & $\begin{array}{r}247 \\
11.9 \%\end{array}$ & $\begin{array}{r}1,825 \\
88.1 \%\end{array}$ & & & \\
\hline $\begin{array}{l}(1) \\
(n=414)\end{array}$ & $\begin{array}{r}64 \\
15.5 \%\end{array}$ & $\begin{array}{r}350 \\
84.5 \% \\
\end{array}$ & & & \\
\hline $\begin{array}{l}(2) \\
(n=229)\end{array}$ & $\begin{array}{r}30 \\
13.1 \%\end{array}$ & $\begin{array}{r}199 \\
86.9 \%\end{array}$ & & & \\
\hline $\begin{array}{l}(3) \\
(n=87)\end{array}$ & $\begin{array}{r}5 \\
5.7 \% \\
\end{array}$ & $\begin{array}{r}82 \\
94.3 \% \\
\end{array}$ & & & \\
\hline $\begin{array}{l}(4) \\
(n=27)\end{array}$ & $\begin{array}{r}4 \\
14.8 \%\end{array}$ & $\begin{array}{r}23 \\
85.2 \% \\
\end{array}$ & & & \\
\hline Family Devel. & & & 11.352 & 4 & .023 \\
\hline $\begin{array}{l}(0) \\
(n=1,463)\end{array}$ & $\begin{array}{r}175 \\
12 \%\end{array}$ & $\begin{array}{r}1,288 \\
88 \%\end{array}$ & & & \\
\hline
\end{tabular}


Table 25 (Continued)

Results of Chi-Square Testing: Case Characteristics by Repeat

Substantiated Maltreatment

\begin{tabular}{|c|c|c|c|c|c|}
\hline \multirow[t]{2}{*}{$\begin{array}{l}\text { Case } \\
\text { Characteristics }\end{array}$} & \multicolumn{2}{|c|}{$\begin{array}{c}\text { Substantiated Referrals } \\
\text { After Case Closure }\end{array}$} & \multirow[t]{2}{*}{$\begin{array}{l}\text { Chi- } \\
\text { Square }\end{array}$} & \multirow[t]{2}{*}{$d f$} & \multirow[t]{2}{*}{ Sig. } \\
\hline & Yes & No & & & \\
\hline \multicolumn{6}{|l|}{ Family Dev. (Cont) } \\
\hline $\begin{array}{l}(1) \\
(n=718)\end{array}$ & $\begin{array}{r}109 \\
15.2 \%\end{array}$ & $\begin{array}{r}609 \\
84.8 \%\end{array}$ & & & \\
\hline $\begin{array}{l}(2) \\
(n=224)\end{array}$ & $\begin{array}{r}36 \\
16.1 \% \\
\end{array}$ & $\begin{array}{r}188 \\
83.9 \%\end{array}$ & & & \\
\hline $\begin{array}{l}(3) \\
(n=120)\end{array}$ & $\begin{array}{r}12 \\
10 \%\end{array}$ & $\begin{array}{r}108 \\
90 \%\end{array}$ & & & \\
\hline $\begin{array}{l}(4) \\
(n=108)\end{array}$ & $\begin{array}{r}7 \\
6.5 \%\end{array}$ & $\begin{array}{r}101 \\
93.5 \%\end{array}$ & & & \\
\hline Adult Patterns & & & 9.150 & 4 & .057 \\
\hline $\begin{array}{l}(0) \\
(n=1,231)\end{array}$ & $\begin{array}{r}147 \\
11.9 \%\end{array}$ & $\begin{array}{r}1,084 \\
88.1 \%\end{array}$ & & & \\
\hline $\begin{array}{l}(1) \\
(n=799)\end{array}$ & $\begin{array}{r}115 \\
14.4 \%\end{array}$ & $\begin{array}{r}684 \\
85.6 \%\end{array}$ & & & \\
\hline $\begin{array}{l}(2) \\
(n=297)\end{array}$ & $\begin{array}{r}49 \\
16.5 \%\end{array}$ & $\begin{array}{r}248 \\
83.5 \%\end{array}$ & & & \\
\hline $\begin{array}{l}(3) \\
(n=127)\end{array}$ & $\begin{array}{r}12 \\
9.4 \%\end{array}$ & $\begin{array}{r}115 \\
90.6 \%\end{array}$ & & & \\
\hline $\begin{array}{l}(4) \\
(n=196)\end{array}$ & $\begin{array}{r}19 \\
9.7 \%\end{array}$ & $\begin{array}{r}177 \\
90.3 \%\end{array}$ & & & \\
\hline Prior Case & & & 33.058 & 1 & .000 \\
\hline $\begin{array}{l}\text { Yes } \\
(n=1,436)\end{array}$ & $\begin{array}{r}228 \\
15.9 \%\end{array}$ & $\begin{array}{r}1,208 \\
84.1 \%\end{array}$ & & & \\
\hline $\begin{array}{l}\text { No } \\
(n=1,393)\end{array}$ & $\begin{array}{r}122 \\
8.8 \%\end{array}$ & $\begin{array}{l}1,271 \\
91.2 \%\end{array}$ & & & \\
\hline $\begin{array}{l}\text { Workers Yr. } \\
\text { Service }\end{array}$ & & & 9.809 & 4 & .044 \\
\hline $\begin{array}{l}\text { Less than } 1 \mathrm{yr} \\
(\mathrm{n}=177)\end{array}$ & $\begin{array}{r}17 \\
9.6 \%\end{array}$ & $\begin{array}{r}160 \\
90.4 \%\end{array}$ & & & \\
\hline $\begin{array}{l}1-5 \mathrm{yrs} \\
(\mathrm{n}=271)\end{array}$ & $\begin{array}{r}38 \\
14 \%\end{array}$ & $\begin{array}{r}233 \\
86 \%\end{array}$ & & & \\
\hline $\begin{array}{l}6-10 \mathrm{yrs} \\
(n=134)\end{array}$ & $\begin{array}{r}25 \\
18.7 \%\end{array}$ & $\begin{array}{r}109 \\
81.3 \%\end{array}$ & & & \\
\hline $\begin{array}{l}11-20 \text { yrs } \\
(n=52)\end{array}$ & $\begin{array}{r}6 \\
11.5 \%\end{array}$ & $\begin{array}{r}46 \\
88.5 \%\end{array}$ & & & \\
\hline $\begin{array}{l}\text { Over } 21 \\
(\mathrm{n}=26)\end{array}$ & & $\begin{array}{r}26 \\
100 \%\end{array}$ & & & \\
\hline
\end{tabular}


Table 26

Results of Chi-Square Testing: Case Characteristics by Reports of Maltreatment, Substantiated and Unsubstantiated

\begin{tabular}{|c|c|c|c|c|c|}
\hline \multirow[t]{2}{*}{$\begin{array}{l}\text { Case } \\
\text { Characteristics }\end{array}$} & \multicolumn{2}{|c|}{$\begin{array}{l}\text { New Reports of Maltreatment } \\
\text { After Case Closure }\end{array}$} & \multirow[t]{2}{*}{$\begin{array}{l}\text { Chi- } \\
\text { Square }\end{array}$} & \multirow[t]{2}{*}{$d f$} & \multirow[t]{2}{*}{ Sig. } \\
\hline & Yes & No & & & \\
\hline CQA Closing & & & 9.894 & 3 & .019 \\
\hline $\begin{array}{l}0-6 \text { Low } \\
(n=2,037)\end{array}$ & $\begin{array}{r}625 \\
30.7 \% \\
\end{array}$ & $\begin{array}{r}1,412 \\
69.3 \%\end{array}$ & & & \\
\hline $\begin{array}{l}\begin{array}{l}7-13 \text { Moderate } \\
(\mathrm{n}=347)\end{array} \\
\end{array}$ & $\begin{array}{r}79 \\
22.8 \% \\
\end{array}$ & $\begin{array}{r}268 \\
77.2 \% \\
\end{array}$ & & & \\
\hline $\begin{array}{l}\text { 14-19 Significant } \\
(\mathrm{n}=59)\end{array}$ & $\begin{array}{r}14 \\
23.7 \% \\
\end{array}$ & $\begin{array}{r}45 \\
76.3 \% \\
\end{array}$ & & & \\
\hline $\begin{array}{l}20-28 \text { High } \\
(n=21)\end{array}$ & $\begin{array}{r}6 \\
28.6 \% \\
\end{array}$ & $\begin{array}{r}15 \\
71.4 \% \\
\end{array}$ & & & \\
\hline $\begin{array}{l}\text { Mudd Safety } \\
\text { Factor at Close }\end{array}$ & & & 32.232 & 4 & .000 \\
\hline $\begin{array}{l} \\
(n=931)\end{array}$ & $\begin{array}{r}245 \\
26.3 \% \\
\end{array}$ & $\begin{array}{r}686 \\
73.7 \% \\
\end{array}$ & & & \\
\hline $\begin{array}{l}1-4 \\
(n=1,225)\end{array}$ & $\begin{array}{r}404 \\
33 \% \\
\end{array}$ & $\begin{array}{r}821 \\
67 \% \\
\end{array}$ & & & \\
\hline $\begin{array}{l}5-8 \\
(n=311)\end{array}$ & $\begin{array}{r}62 \\
19.9 \% \\
\end{array}$ & $\begin{array}{r}249 \\
80.1 \% \\
\end{array}$ & & & \\
\hline $\begin{array}{l}9-12 \\
(n=35)\end{array}$ & $\begin{array}{r}8 \\
22.9 \% \\
\end{array}$ & $\begin{array}{r}27 \\
77.1 \% \\
\end{array}$ & & & \\
\hline $\begin{array}{l}\begin{array}{l}13-16 \\
(n=81)\end{array} \\
(n-10\end{array}$ & $\begin{array}{r}13 \\
16 \% \\
\end{array}$ & $\begin{array}{r}68 \\
84 \% \\
\end{array}$ & & & \\
\hline Prior Case & & & 89.692 & 1 & .000 \\
\hline $\begin{array}{l}\text { Yes } \\
(n=1,436)\end{array}$ & $\begin{array}{r}488 \\
34 \% \\
\end{array}$ & $\begin{array}{r}948 \\
66 \% \\
\end{array}$ & & & \\
\hline $\begin{array}{l}\text { No } \\
(n=1392)\end{array}$ & $\begin{aligned} 278 \\
20 \% \\
\end{aligned}$ & $\begin{array}{r}1,114 \\
80 \% \\
\end{array}$ & & & \\
\hline $\begin{array}{l}\text { Sub. Referrals in } \\
\text { Case at Closure }\end{array}$ & & & 14.716 & 3 & .002 \\
\hline $\begin{array}{l}1 \\
(n=1,620)\end{array}$ & $\begin{array}{r}404 \\
24.9 \% \\
\end{array}$ & $\begin{array}{r}1,216 \\
75.1 \\
\end{array}$ & & & \\
\hline $\begin{array}{l}2 \\
(n=628)\end{array}$ & $\begin{array}{r}186 \\
29.6 \% \\
\end{array}$ & $\begin{array}{r}442 \\
70.4 \% \\
\end{array}$ & & & \\
\hline $\begin{array}{l}3 \\
(n=232)\end{array}$ & $\begin{array}{r}83 \\
35.8 \% \\
\end{array}$ & $\begin{array}{r}149 \\
64.2 \% \\
\end{array}$ & & & \\
\hline $\begin{array}{l}\text { Over } 3 \\
(n=348)\end{array}$ & $\begin{array}{r}93 \\
26.7 \% \\
\end{array}$ & $\begin{array}{r}255 \\
73.3 \% \\
\end{array}$ & & & \\
\hline
\end{tabular}


Table 26 (Continued)

Results of Chi-Square Testing: Case Characteristics by Reports of Maltreatment, Substantiated and Unsubstantiated

\begin{tabular}{|c|c|c|c|c|c|}
\hline \multirow[t]{2}{*}{$\begin{array}{l}\text { Case } \\
\text { Characteristics }\end{array}$} & \multicolumn{2}{|c|}{$\begin{array}{l}\text { New Reports of Maltreatment } \\
\text { After Case Closure }\end{array}$} & \multirow[t]{2}{*}{$\begin{array}{l}\text { Chi- } \\
\text { Square }\end{array}$} & \multirow[t]{2}{*}{$d f$} & \multirow[t]{2}{*}{ Sig. } \\
\hline & Yes & No & & & \\
\hline Program & & & 27.517 & 5 & .000 \\
\hline $\begin{array}{l}\text { Placement } \\
(n=530)\end{array}$ & $\begin{array}{r}107 \\
20.2 \% \\
\end{array}$ & $\begin{array}{r}423 \\
79.8 \% \\
\end{array}$ & & & \\
\hline $\begin{array}{l}\text { Neglect } \\
(n=1003)\end{array}$ & $\begin{array}{r}314 \\
31.3 \%\end{array}$ & $\begin{array}{r}689 \\
68.7 \%\end{array}$ & & & \\
\hline $\begin{array}{l}\text { Physical Abuse } \\
(\mathrm{n}=557)\end{array}$ & $\begin{array}{r}162 \\
29.1 \% \\
\end{array}$ & $\begin{array}{r}395 \\
70.9 \% \\
\end{array}$ & & & \\
\hline $\begin{array}{l}\text { Community } \\
(n=172)\end{array}$ & $\begin{array}{r}35 \\
20.3 \% \\
\end{array}$ & $\begin{array}{r}137 \\
79.7 \% \\
\end{array}$ & & & \\
\hline $\begin{array}{l}\text { Sexual Abuse } \\
(n=125)\end{array}$ & $\begin{array}{r}30 \\
24 \% \\
\end{array}$ & $\begin{array}{r}95 \\
76 \% \\
\end{array}$ & & & \\
\hline $\begin{array}{l}\text { Other } \\
(n=441)\end{array}$ & $\begin{array}{r}118 \\
26.8 \% \\
\end{array}$ & $\begin{array}{r}323 \\
73.2 \% \\
\end{array}$ & & & \\
\hline Region & & & 4.702 & 2 & .095 \\
\hline $\begin{array}{l}\text { Urban } \\
(n=1225)\end{array}$ & $\begin{array}{r}356 \\
29.1 \% \\
\end{array}$ & $\begin{array}{r}869 \\
70.9 \% \\
\end{array}$ & & & \\
\hline $\begin{array}{l}\text { Appalachian } \\
(\mathrm{n}=754)\end{array}$ & $\begin{array}{r}187 \\
24.8 \% \\
\end{array}$ & $\begin{array}{r}567 \\
75.2 \%\end{array}$ & & & \\
\hline $\begin{array}{l}\text { Rural } \\
(n=824)\end{array}$ & $\begin{array}{r}223 \\
26.3 \% \\
\end{array}$ & $\begin{array}{r}626 \\
72.9 \% \\
\end{array}$ & & & \\
\hline Position & & & 10.637 & 3 & .005 \\
\hline $\begin{array}{l}\text { Worker } \\
(n=1,711)\end{array}$ & $\begin{array}{r}497 \\
29 \% \\
\end{array}$ & $\begin{array}{r}1,214 \\
71 \% \\
\end{array}$ & & & \\
\hline $\begin{array}{l}\text { Clinician } \\
(n=848)\end{array}$ & $\begin{array}{r}196 \\
23.1 \% \\
\end{array}$ & $\begin{array}{r}652 \\
76.9 \% \\
\end{array}$ & & & \\
\hline $\begin{array}{l}\text { Specialist } \\
\text { Supervisor } \\
(n=142)\end{array}$ & $\begin{array}{r}35 \\
24.6 \%\end{array}$ & $\begin{array}{r}107 \\
75.4 \%\end{array}$ & & & \\
\hline Region & & & 25.640 & 15 & .042 \\
\hline $\begin{array}{l}\text { Barren River } \\
(n=157)\end{array}$ & $\begin{array}{r}49 \\
28.5 \% \\
\end{array}$ & $\begin{array}{r}123 \\
71.5 \% \\
\end{array}$ & & & \\
\hline $\begin{array}{l}\text { Big Sandy } \\
(\mathrm{n}=77)\end{array}$ & $\begin{array}{r}25 \\
27.8 \% \\
\end{array}$ & $\begin{array}{r}65 \\
72.2 \% \\
\end{array}$ & & & \\
\hline $\begin{array}{l}\text { Bluegrass/Fayette } \\
(n=94)\end{array}$ & $\begin{array}{r}35 \\
28.7 \%\end{array}$ & $\begin{array}{r}87 \\
71.3 \%\end{array}$ & & & \\
\hline $\begin{array}{l}\text { Bluegrass Rural } \\
(n=321)\end{array}$ & $\begin{array}{r}91 \\
24.1 \\
\end{array}$ & $\begin{array}{r}286 \\
75.9 \% \\
\end{array}$ & & & \\
\hline
\end{tabular}


Table 26 (Continued)

Results of Chi-Square Testing: Case Characteristics by Reports of

Maltreatment, Substantiated and Unsubstantiated

\begin{tabular}{|c|c|c|c|c|c|}
\hline \multirow[t]{2}{*}{\begin{tabular}{|l|} 
Case \\
Characteristics \\
\end{tabular}} & \multicolumn{2}{|c|}{$\begin{array}{l}\text { New Reports of Maltreatment } \\
\text { After Case Closure }\end{array}$} & \multirow[t]{2}{*}{$\begin{array}{l}\text { Chi- } \\
\text { Square } \\
\end{array}$} & \multirow[t]{2}{*}{$d f$} & \multirow[t]{2}{*}{ Sig. } \\
\hline & Yes & No & & & \\
\hline \multicolumn{6}{|l|}{ Region (Cont.) } \\
\hline $\begin{array}{l}\text { Cumberland Valley } \\
(n=167)\end{array}$ & $\begin{array}{r}35 \\
18.4 \% \\
\end{array}$ & $\begin{array}{r}155 \\
81.6 \% \\
\end{array}$ & & & \\
\hline $\begin{array}{l}\text { Fivco } \\
(n=83)\end{array}$ & $\begin{array}{r}24 \\
25.8 \%\end{array}$ & $\begin{array}{r}69 \\
74.2 \%\end{array}$ & & & \\
\hline $\begin{array}{l}\text { Gateway/Buffalo } \\
(n=111)\end{array}$ & $\begin{array}{r}36 \\
27.5 \%\end{array}$ & $\begin{array}{r}95 \\
72.5 \%\end{array}$ & & & \\
\hline $\begin{array}{l}\text { Green River } \\
(n=167)\end{array}$ & $\begin{array}{r}55 \\
30.9 \%\end{array}$ & $\begin{array}{r}123 \\
69.1 \%\end{array}$ & & & \\
\hline $\begin{array}{l}\text { Kentucky River } \\
(n=100)\end{array}$ & $\begin{array}{r}31 \\
29.5 \%\end{array}$ & $\begin{array}{r}74 \\
70.5 \%\end{array}$ & & & \\
\hline $\begin{array}{l}\text { KIPDA/Jefferson } \\
(n=453)\end{array}$ & $\begin{array}{r}162 \\
31 \%\end{array}$ & $\begin{array}{r}361 \\
69 \%\end{array}$ & & & \\
\hline $\begin{array}{l}\text { KIPDA/Rural } \\
(n=63)\end{array}$ & $\begin{array}{r}17 \\
23.6 \%\end{array}$ & $\begin{array}{r}55 \\
76.4 \%\end{array}$ & & & \\
\hline $\begin{array}{l}\text { Lake Cumberland } \\
(n=126)\end{array}$ & $\begin{array}{r}36 \\
24.8 \%\end{array}$ & $\begin{array}{r}109 \\
75.2 \%\end{array}$ & & & \\
\hline $\begin{array}{l}\text { Lincoln Trail } \\
(n=149)\end{array}$ & \begin{tabular}{r|}
52 \\
$31 \%$
\end{tabular} & $\begin{array}{r}116 \\
69 \%\end{array}$ & & & \\
\hline $\begin{array}{l}\text { Northern KY } \\
(n=236)\end{array}$ & $\begin{array}{r}83 \\
30.1 \%\end{array}$ & $\begin{array}{r}193 \\
69.9 \%\end{array}$ & & & \\
\hline $\begin{array}{l}\text { Pennyrile } \\
(n=110)\end{array}$ & $\begin{array}{r}21 \\
16.7 \%\end{array}$ & $\begin{array}{r}105 \\
83.3 \%\end{array}$ & & & \\
\hline $\begin{array}{l}\text { Purchase } \\
(n=51)\end{array}$ & \begin{tabular}{r|}
14 \\
$23.3 \%$
\end{tabular} & $\begin{array}{r}46 \\
76.6 \%\end{array}$ & & & \\
\hline \multicolumn{6}{|l|}{ Risk Fields (open) } \\
\hline Maltreatment & & & 12.718 & 4 & .013 \\
\hline $\begin{array}{l}(0) \\
(n=617)\end{array}$ & \begin{tabular}{r|}
159 \\
$25.8 \%$ \\
\end{tabular} & $\begin{array}{r}458 \\
74.2 \% \\
\end{array}$ & & & \\
\hline $\begin{array}{l}(1) \\
n=349)\end{array}$ & $\begin{array}{r}86 \\
24.6 \% \\
\end{array}$ & $\begin{array}{r}263 \\
75.4 \%\end{array}$ & & & \\
\hline $\begin{array}{l}(3) \\
(n=674)\end{array}$ & \begin{tabular}{r|}
179 \\
$26.6 \%$ \\
\end{tabular} & $\begin{array}{r}495 \\
73.4 \%\end{array}$ & & & \\
\hline $\begin{array}{l}(4) \\
(n=511)\end{array}$ & $\begin{array}{r}124 \\
24.3 \% \\
\end{array}$ & $\begin{array}{r}387 \\
75.7 \%\end{array}$ & & & \\
\hline $\begin{array}{l}\text { Sequence of } \\
\text { Events }\end{array}$ & & & 25.115 & 4 & .000 \\
\hline $\begin{array}{l}(0) \\
(n=412)\end{array}$ & \begin{tabular}{r|}
88 \\
$21.4 \%$ \\
\end{tabular} & $\begin{array}{r}324 \\
78.65 \\
\end{array}$ & & & \\
\hline $\begin{array}{l}(1) \\
(n=452)\end{array}$ & $\begin{array}{r}118 \\
26.1 \% \\
\end{array}$ & $\begin{array}{r}334 \\
73.9 \% \\
\end{array}$ & & & \\
\hline
\end{tabular}


Table 26 (Continued)

Results of Chi-Square Testing: Case Characteristics by Reports of Maltreatment, Substantiated and Unsubstantiated

\begin{tabular}{|c|c|c|c|c|c|}
\hline \multirow[t]{2}{*}{$\begin{array}{l}\text { Case } \\
\text { Characteristics }\end{array}$} & \multicolumn{2}{|c|}{$\begin{array}{c}\text { New Reports of Maltreatment } \\
\text { After Case Closure }\end{array}$} & \multirow[t]{2}{*}{$\begin{array}{l}\text { Chi- } \\
\text { Square }\end{array}$} & \multirow[t]{2}{*}{$d f$} & \multirow[t]{2}{*}{ Sig. } \\
\hline & Yes & No & & & \\
\hline Sequence (Cont.) & & & & & \\
\hline $\begin{array}{l}(2) \\
(n=887)\end{array}$ & $\begin{array}{r}292 \\
32.9 \%\end{array}$ & $\begin{array}{r}595 \\
67 / 1 \%\end{array}$ & & & \\
\hline $\begin{array}{l}(3) \\
(n=746)\end{array}$ & $\begin{array}{r}188 \\
25.2 \%\end{array}$ & $\begin{array}{r}588 \\
74.8 \%\end{array}$ & & & \\
\hline $\begin{array}{l}(4) \\
(n=331)\end{array}$ & $\begin{array}{r}80 \\
24.2 \%\end{array}$ & $\begin{array}{r}251 \\
75.8 \%\end{array}$ & & & \\
\hline Family Devel. & & & 11.130 & 4 & .025 \\
\hline $\begin{array}{l}(0) \\
(n=278)\end{array}$ & $\begin{array}{r}83 \\
23 \% \\
\end{array}$ & $\begin{array}{r}278 \\
77 \% \\
\end{array}$ & & & \\
\hline $\begin{array}{l}(1) \\
(n=783)\end{array}$ & $\begin{array}{r}226 \\
28.9 \% \\
\end{array}$ & $\begin{array}{r}557 \\
71.1 \% \\
\end{array}$ & & & \\
\hline $\begin{array}{l}(2) \\
(n=630)\end{array}$ & $\begin{array}{r}195 \\
31 \%\end{array}$ & $\begin{array}{r}435 \\
69 \%\end{array}$ & & & \\
\hline $\begin{array}{l}(3) \\
(n=517)\end{array}$ & $\begin{array}{r}134 \\
25.9 \% \\
\end{array}$ & $\begin{array}{r}383 \\
74.1 \% \\
\end{array}$ & & & \\
\hline $\begin{array}{l}(4) \\
(n=410)\end{array}$ & $\begin{array}{r}99 \\
24.1 \%\end{array}$ & $\begin{array}{r}311 \\
75.9 \%\end{array}$ & & & \\
\hline Family Support & & & 14.459 & 4 & .006 \\
\hline $\begin{array}{l}(0) \\
(n=1406)\end{array}$ & $\begin{array}{r}350 \\
24.9 \% \\
\end{array}$ & $\begin{array}{r}1056 \\
75.1 \% \\
\end{array}$ & & & \\
\hline $\begin{array}{l}(1) \\
(n=672)\end{array}$ & $\begin{array}{r}213 \\
31.7 \% \\
\end{array}$ & $\begin{array}{r}459 \\
68.3 \% \\
\end{array}$ & & & \\
\hline $\begin{array}{l}(2) \\
(n=476)\end{array}$ & $\begin{array}{r}136 \\
28.6 \% \\
\end{array}$ & $\begin{array}{r}340 \\
71.4 \% \\
\end{array}$ & & & \\
\hline $\begin{array}{l}(3) \\
(n=128)\end{array}$ & $\begin{array}{r}32 \\
25 \%\end{array}$ & $\begin{array}{r}96 \\
75 \%\end{array}$ & & & \\
\hline $\begin{array}{l}(4) \\
(n=72)\end{array}$ & $\begin{array}{r}13 \\
18.1 \% \\
\end{array}$ & $\begin{array}{r}59 \\
81.9 \% \\
\end{array}$ & & & \\
\hline $\begin{array}{l}\text { CQA Risk Fields } \\
\text { Closing }\end{array}$ & & & & & \\
\hline $\begin{array}{l}\text { Sequence of } \\
\text { Events }\end{array}$ & & & 11.509 & 4 & .021 \\
\hline $\begin{array}{l}(0) \\
(n=2072)\end{array}$ & $\begin{array}{r}547 \\
26.4 \% \\
\end{array}$ & $\begin{array}{r}1,525 \\
73.6 \% \\
\end{array}$ & & & \\
\hline $\begin{array}{l}(1) \\
(n=413)\end{array}$ & $\begin{array}{r}133 \\
32.2 \% \\
\end{array}$ & $\begin{array}{r}280 \\
67.8 \% \\
\end{array}$ & & & \\
\hline $\begin{array}{l}(2) \\
(n=229)\end{array}$ & $\begin{array}{r}65 \\
28.4 \% \\
\end{array}$ & $\begin{array}{r}164 \\
71.6 \% \\
\end{array}$ & & & \\
\hline $\begin{array}{l}(3) \\
(n=87)\end{array}$ & $\begin{array}{r}14 \\
16.1 \% \\
\end{array}$ & $\begin{array}{r}73 \\
83.9 \% \\
\end{array}$ & & & \\
\hline
\end{tabular}


Table 26 (Continued)

Results of Chi-Square Testing: Case Characteristics by Reports of

Maltreatment, Substantiated and Unsubstantiated

\begin{tabular}{|c|c|c|c|c|c|}
\hline \multirow[t]{2}{*}{$\begin{array}{l}\text { Case } \\
\text { Characteristics }\end{array}$} & \multicolumn{2}{|c|}{$\begin{array}{c}\text { New Reports of Maltreatment } \\
\text { After Case Closure }\end{array}$} & \multirow[t]{2}{*}{$\begin{array}{l}\text { Chi- } \\
\text { Square }\end{array}$} & \multirow[t]{2}{*}{$d f$} & \multirow[t]{2}{*}{ Sig. } \\
\hline & Yes & No & & & \\
\hline Sequence (Cont.) & & & 11.509 & 4 & .021 \\
\hline $\begin{array}{l}(4) \\
(n=27)\end{array}$ & $\begin{array}{r}7 \\
25.9 \%\end{array}$ & $\begin{array}{r}20 \\
74.1 \%\end{array}$ & & & \\
\hline Family Devel. & & & 21.235 & 4 & .000 \\
\hline $\begin{array}{l}(0) \\
(n=1463)\end{array}$ & $\begin{array}{r}417 \\
28.5 \%\end{array}$ & $\begin{array}{r}1,046 \\
71.5 \%\end{array}$ & & & \\
\hline $\begin{array}{l}(1) \\
(\mathrm{n}=717)\end{array}$ & $\begin{array}{r}220 \\
30.7 \%\end{array}$ & $\begin{array}{r}497 \\
69.3 \%\end{array}$ & & & \\
\hline $\begin{array}{l}(2) \\
(n=224)\end{array}$ & $\begin{array}{r}66 \\
29.5 \%\end{array}$ & $\begin{array}{r}158 \\
70.5 \%\end{array}$ & & & \\
\hline $\begin{array}{l}(3) \\
(n=120)\end{array}$ & $\begin{array}{r}23 \\
19.2 \%\end{array}$ & $\begin{array}{r}97 \\
80.8 \%\end{array}$ & & & \\
\hline $\begin{array}{l}(4) \\
(n=108)\end{array}$ & $\begin{array}{r}13 \\
12 \%\end{array}$ & $\begin{array}{r}95 \\
88 \%\end{array}$ & & & \\
\hline Adult Patterns & & & 18.321 & 4 & .001 \\
\hline $\begin{array}{l}(0) \\
(n=1231)\end{array}$ & $\begin{array}{r}339 \\
27.5 \%\end{array}$ & $\begin{array}{r}892 \\
72.5 \%\end{array}$ & & & \\
\hline $\begin{array}{l}(1) \\
(n=798)\end{array}$ & $\begin{array}{r}260 \\
32.6 \% \\
\end{array}$ & $\begin{array}{r}538 \\
67.4 \% \\
\end{array}$ & & & \\
\hline $\begin{array}{l}(2) \\
(n=297)\end{array}$ & $\begin{array}{r}82 \\
27.6 \% \\
\end{array}$ & $\begin{array}{r}215 \\
72.4 \% \\
\end{array}$ & & & \\
\hline $\begin{array}{l}(3) \\
(n=127)\end{array}$ & $\begin{array}{r}25 \\
19.7 \%\end{array}$ & $\begin{array}{r}102 \\
80.3 \% \\
\end{array}$ & & & \\
\hline $\begin{array}{l}(4) \\
(n=196)\end{array}$ & $\begin{array}{r}40 \\
20.4 \%\end{array}$ & $\begin{array}{r}156 \\
79.6 \%\end{array}$ & & & \\
\hline
\end{tabular}

cases having the highest CQA scores (20-28) at opening had a new report. However, mixed findings were evidenced by $30 \%$ of those with the lowest CQA scores at closing having at least one new report of maltreatment following case closure, while only $28.6 \%$ of those with the highest closing CQA scores had a new report. 
Significant relationships were found between substantiated maltreatment

following case closure and (a) closing Mudd safety factor score, (b) opening CQA risk domain scores for sequence of events, family development, and family support, and (c) closing CQA scores for sequence of events, family development, and adult patterns of behavior. Again, however, the findings were mixed with low closing Mudd safety scores having higher percentages of substantiated maltreatment than those with high closing Mudd safety scores.

Research Question 3: What are the relationships between services provided by the Kentucky Department of Protection and Permanency and repeat maltreatment following case closure?

The nominal/ordinal variables found to have a significant relationship to substantiated referrals after case closure included (a) the number of substantiated referrals in the case at time of case closure, (b) prior episode of treatment, and (c) case manager's years of experience (Table 25). Variables not having a significant relationship to repeat substantiated referrals included (a) supervisor gender, area of study, years of service, and degree, (b) current case plan at time of case closure, (c) position of case manager, (d) case manager's area of study, gender, and degree, (e) child 3 and under listed as victim, (f) length of time case open for current treatment episode, and $(\mathrm{g})$ primary program of service.

Variables found to be significantly associated with reports of maltreatment received after closure (substantiated and unsubstantiated referrals) included: (a) prior episode of treatment, (b) worker's years of experience, (c) primary program 
of service, (d) the number of substantiated referrals in the case at closure, (e) region, and (f) position of case manager (Table 26). Variables found not to have a significant relationship to reports of maltreatment received after closure included (a) time case was open for a prior treatment episode, (b) supervisor area of study, degree, years of service and gender, (c) case manager's area of study, degree, and gender, (d) number of children in referrals, (e) current case plan, and (f) victim age 3 and under.

Primary program of service was significantly related to reports of maltreatment after closure, but not to substantiated repeat maltreatment. Neglect had the highest percentage of reports of maltreatment following case closure (31.3\%), closely followed by physical abuse (29.1\%). Remember, however, that programs of service were not mutually exclusive and it is likely that cases had multiple program areas during the life of the case.

Prior episode of treatment was found to be significantly related to substantiated referrals after case closure and also to reports of maltreatment after closure. Fifteen percent of those with a prior episode of treatment had a substantiated incident of maltreatment following case closure, while only $8.8 \%$ of those without a prior episode of treatment had a new substantiated incident of maltreatment following the most recent case closure. Likewise, $34 \%$ of those with a prior episode of treatment had a new report of maltreatment following closure, while only $20 \%$ of those without a prior episode of treatment had a new incident of maltreatment. 
Number of substantiated referrals in case at closure was significantly related to substantiated referrals after case closure. Cases with more than one substantiated referral in the case at closure had higher percentages of repeat substantiated maltreatment following case closure. Ten percent of cases with only 1 substantiated referral at case closure had a new substantiated incident of maltreatment following case closure, while $14 \%$ of those with more than 1 substantiated referral had a new incident of maltreatment.

In summary, some of the identified variables were significantly related to just substantiated referrals, while others were related to only the broader dependent variable of reports of maltreatment. Variables related to both classifications of repeat maltreatment included: (a) cases having a prior episode of treatment, (b) CQA opening and closing Sequence of Events, (c) Mudd safety factor at closing, (d) CQA opening and closing Family Development, (e) number of substantiated referrals in the case at time of case closure, (f) case manager years of service, (g) CQA closing Adult Patterns, and (h) CQA opening Family Support.

Case Manager Demographics: Research Questions Four and Five Research Question 4: What are the relationships between change in the level of risk and case manager demographics for child protective services?

Research Question 5: What are the relationships between repeat maltreatment following case closure and case manager demographics? 


\section{Demographics of Population}

The Council on Accreditation (COA) recognizes the Social Work degree as the professional standard for casework in child protection. Related degrees, including counseling, psychology, human studies, family studies, and sociology are also recognized as acceptable degrees. Case managers with social work degrees managed $37.7 \%$ of the study cases (Table 27). However, case managers with degrees accepted by COA as meeting the standard for child protective work managed $73.6 \%$ of the cases in the study. Seven hundred and eighty-three unique case managers were involved in the study with responsibility ranging from 1 to 41 study cases. The gender of case managers for the study cases was $75 \%$ female, $21 \%$ male, and $4 \%$ unknown.

COA recognizes the Master of Social Work (MSW) Degree as the professional standard for supervision within the field of child protection. The Council also recognizes Masters of Counseling and Psychology Degrees as acceptable supervisory degrees. Thus, $26.9 \%$ of the cases involved in the study were provided supervision by a COA recognized master leveled supervisor (Table 28). Two hundred and seventeen unique supervisors were included in the study, with responsibility of study cases ranging from 1 to 85 . The gender of supervisors for the study cases was (a) $73 \%$ female, (b) $24 \%$ male, and (c) $3 \%$ unknown.

Case managers at the time of case closure were classified as worker, clinician, specialist, and supervisor. A frequency of position revealed that case management responsibility of study cases was (a) $60.5 \%$ worker, (b) $30 \%$ 
Table 27

Case Manager's Area of Study and Highest Educational Degree

\begin{tabular}{|c|c|c|c|c|c|c|}
\hline $\begin{array}{l}\text { Case Manager's Area } \\
\text { of Study }\end{array}$ & Numbe & $\begin{array}{r}\text { of Cases by } \\
\text { Case Ma }\end{array}$ & $\begin{array}{l}\text { Highest } \\
\text { nager }\end{array}$ & egree of & $\begin{array}{r}\text { Number o } \\
\text { Case M } \\
\text { Disci }\end{array}$ & $\begin{array}{l}\text { f Cases by } \\
\text { anagers } \\
\text { plines }\end{array}$ \\
\hline & Master & $\begin{array}{c}\text { Percentage } \\
\text { Per } \\
\text { Total } \\
\text { Population }\end{array}$ & Bachelor & $\begin{array}{c}\text { Percentage } \\
\text { Per } \\
\text { Total } \\
\text { Population }\end{array}$ & Frequency & $\begin{array}{c}\text { Percentage } \\
\text { Per } \\
\text { Total } \\
\text { Population }\end{array}$ \\
\hline Social Work & 196 & 7.1 & 847 & 30.6 & 1,043 & 37.7 \\
\hline Counseling & 55 & 2 & 12 & .40 & 67 & 2.4 \\
\hline Other & 42 & 1.5 & 103 & 3.7 & 145 & 5.2 \\
\hline Psychology & 37 & 1.3 & 354 & 12.8 & 391 & 14.1 \\
\hline $\begin{array}{l}\text { Unspecified--Not } \\
\text { Social Work }\end{array}$ & 26 & .9 & 393 & 14.2 & 419 & 15.1 \\
\hline Human Studies & 10 & .4 & 133 & 4.8 & 143 & 5.2 \\
\hline Sociology & 7 & .3 & 385 & 13.9 & 392 & 14.2 \\
\hline Corrections/Justice & 6 & 3.6 & 160 & 5.8 & 166 & 6 \\
\hline Total & 379 & 13.7 & 2,387 & 86.3 & 2,766 & 97.9 \\
\hline
\end{tabular}

clinician, (c) $2.1 \%$ specialist and (d) $2.9 \%$ supervisor. CFC case managers, classified as workers, would generally have less than 2 years of experience or be less proficient than those classified as clinicians.

Years of service for workers and supervisors were available for only six regions: Barren River, Bluegrass/Fayette, Fivco, Gateway/Buffalo Trace, Lincoln Trail, and Northern Kentucky. Thus years of service data analysis is reflective of cases within only those 6 regions. There was a significant difference between the overall mean years of worker service ( 4.51 years) and the overall mean years 
Table 28

Supervisor Area of Study and Highest Educational Degree

\begin{tabular}{|c|c|c|c|c|c|c|}
\hline \multirow[t]{2}{*}{ Supervisors' Area of Study } & \multicolumn{4}{|c|}{$\frac{\text { Number of Cases by Highest }}{\text { Degree of Supervisor }}$} & \multicolumn{2}{|c|}{$\frac{\text { Number of Cases }}{\text { by Discipline }}$} \\
\hline & Master & $\begin{array}{c}\text { Percent } \\
\text { Of } \\
\text { Total } \\
\text { Population }\end{array}$ & Bachelor & $\begin{array}{c}\text { Percent } \\
\text { Of } \\
\text { Total } \\
\text { Population }\end{array}$ & Frequency & $\begin{array}{c}\text { Percent } \\
\text { Of } \\
\text { Total } \\
\text { Population }\end{array}$ \\
\hline Social Work & 544 & 19.7 & 702 & 25.4 & 1,246 & 45.1 \\
\hline Counseling & 159 & 5.8 & 0 & 0 & 159 & 5.8 \\
\hline Other & 93 & 3.4 & 147 & 5.3 & 240 & 8.7 \\
\hline Human Studies/Services & 62 & 2.3 & 51 & 1.8 & 113 & 4.1 \\
\hline Psychology & 38 & 1.4 & 364 & 13.2 & 402 & 14.5 \\
\hline $\begin{array}{l}\text { Unspecified--Not Social } \\
\text { Work }\end{array}$ & 34 & 1.2 & 251 & 9.1 & 285 & 10.3 \\
\hline Sociology & 12 & .4 & 214 & 7.7 & 226 & 8.2 \\
\hline $\begin{array}{l}\text { Corrections/Criminal } \\
\text { Justice }\end{array}$ & 9 & .3 & 84 & 3 & 93 & 3.4 \\
\hline Total & 951 & 34.4 & 1,813 & 65.6 & 2,764 & 97.7 \\
\hline
\end{tabular}

of supervisor service (15.1 years) for the study cases. Of the 756 cases considered with worker years of service, one-way ANOVA testing revealed that there was a significant difference $(p<.001)$ between position classification of case manager and years of service (Table 29 ). Only $3.2 \%$ of those classified as workers had more than 5 years of experience, while $55.5 \%$ of those classified as clinicians and $95 \%$ of those classified as specialist or supervisor had more than 5 years of experience. 
Examination of cumulative CQA scores by area of study for supervisors revealed that scores for those with social work degrees was nearly equal to the overall mean. One-way ANOVA testing revealed that there was a significant difference $(p<.05)$ in closing CQA scores for supervisors by area of study (Table 30). Examination of cumulative CQA scores by area of study for case managers with social work degrees revealed that those with social work degrees was slightly below the overall mean, however, one-way ANOVA testing revealed there was no significant difference between the areas and closing CQA scores.

\section{Table 29}

Comparison of Years of Service and Worker Position

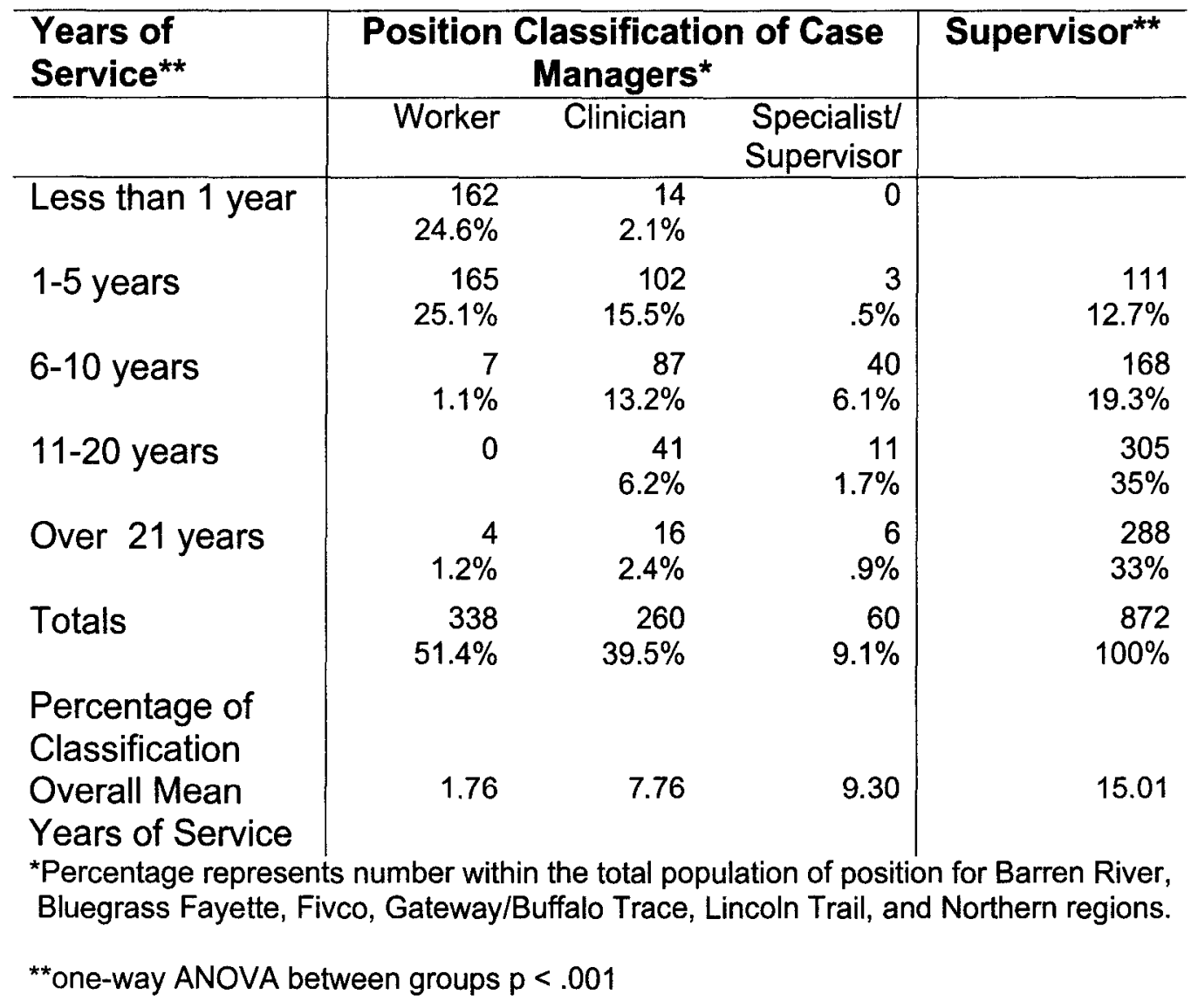


Table 30

Comparison of Overall Means of Case Managers/Supervisors and Closing Cumulative CQA Scores

\begin{tabular}{lrrrr}
\hline Area of Study & \multicolumn{4}{c}{$\begin{array}{c}\text { Case Manager/Supervisor } \\
\text { Closing CQA Cumulative Scores }\end{array}$} \\
\hline & \multicolumn{2}{c}{ Supervisor } & \multicolumn{2}{c}{ Case Manager } \\
& CQA Score & Number & CQA Score & Number \\
\hline Counseling & 4.36 & 137 & 4.15 & 62 \\
Other & 4.15 & 458 & 3.85 & 389 \\
Human Studies & 3.87 & 89 & 4.83 & 98 \\
Social Work & 3.64 & 1,071 & 3.59 & 903 \\
Sociology & 3.62 & 202 & 3.36 & 352 \\
Psychology & 3.16 & 363 & 3.87 & 334 \\
Corrections & 3.15 & 87 & 3.63 & 119 \\
Total/Overall Mean & 3.69 & 2,416 & 3.72 & 2,423 \\
*one-way ANOVA between groups $\mathrm{p}<.001$ & & & \\
& & & & \\
\hline
\end{tabular}

Restatement of and Answers to Questions Four and Five

Research question 4: What are the relationships between change in the level of risk and case manager's demographics for child protective services?

Using bivariate analysis to examine relationships and differences, case manager demographics found to be associated with greater reduction in risk were (a) workers' years of service and (b) workers' position. Workers' areas of study and gender, and supervisors' years of service were not found to be significantly related to reduction in risk. 
Worker position and worker years of experience had significant relationships with reduction in safety risk domain scores (Table 20). Workers' years of service was significantly related to worker position $(p<.001)$. Only $3.2 \%$ of those classified as workers had more than 5 years of experience, while $55.5 \%$ of those classified as clinicians and $95 \%$ of those classified as specialist/supervisor had more than 5 years of experience. As years of service were available for only 6 regions, position (available for all regions in state) was examined. Reduction in safety factor scores were higher with those classified with higher levels of expertise. Eighteen percent of cases with a worker as case manager had risk reductions in the highest category (11-16 points), while clinicians had $19 \%$, specialists had $21 \%$ and supervisors had $23 \%$.

Supervisor's gender was found to be significantly related to the cumulative CQA rating at case closure $(p<.001)($ Table 18$)$. The overall mean of closing cumulative CQA scores was slightly higher for males (4.04) than for females (3.58). The small difference, however, does not appear to be clinically significant. Males rated $4.4 \%$ of their cases as significant or high risk at closing, while females rated only $2.7 \%$ of their cases as significant or high risk at closure. The relationship between supervisor's area of study and CQA cumulative rating at closing approached being significant in determining amount of risk $(p<.067)$ (Table 18). Overall means of closing CQA scores for supervisors ranged from 3.15 to 4.36 (Table 30 ). The CQA risk rating assessment scale considers cumulative scores from 0 to 6.9 to be low risk. Therefore, considering the low risk ratings and small range in supervisors' ratings by area of study, the 
difference in ratings appears to have little clinical significance. Supervisor's area of study was also found to approach significance $(p<.08)$ in its relationship to change in CQA ratings between opening and closing (reduction in risk) (Table 19). As with closing CQA ratings, the overall low ratings and small range of difference between CQA ratings for supervisors by area of study would suggest little clinical significance in reduction of risk for supervisors by area of study.

Examination of supervisor area of study by reduction in safety rating from opening to closing revealed that cases with supervisors having social work as their area of study had lower change scores (less reduction in risk) than all areas except the "other" category (Table 20). The overall mean of reduction in risk for workers' with social work degrees was 5.72 , while the highest mean of reduction in risk was found in cases managed by workers' with Sociology degrees 6.96 . Change in $56 \%$ of the cases managed by workers' with Sociology degrees was rated in the two highest categories, while only $42.2 \%$ of workers' with social work degrees was rated change in the two highest categories.

Supervisor gender was also found to have a significant relationship to safety change (Table 20 ). Reduction in risk in $38.4 \%$ of cases with male supervisors was found to be in the two highest categories of change, while $46.6 \%$ of those cases with females as supervisors rated in the two highest categories. Thus, cases with female supervisors had greater reductions in risk.

Research question 5: What are the relationships between repeat maltreatment following case closure and case manager demographics? 
Using bivariate analysis to examine relationships and differences, case manager demographics found to be associated with repeat maltreatment were workers' years of experience and worker position. Workers' years of experience was found to have a significant relationship to repeat substantiated maltreatment $(p<.04)$ (Table 25). Comparison of the means of substantiated referrals by workers years of service, however, revealed that there was very little difference between groups. The number of substantiated referrals varied from 1.08 to 1.39 for the different lengths of service with the agency.

Worker position was significantly related to reports of maltreatment following closure (substantiated and unsubstantiated referrals) (Table 26). The percentage of recidivism ranged from a high of $29 \%$ with workers to a low of $23.1 \%$ with clinicians. Thus, those with less experience had higher numbers of recurrent maltreatment following case closure.

The findings of this study (a) provided Kentucky and study population demographics, (b) examined the CQA tool, and (c) examined and provided answers to each of the research questions. Discussion of these findings will be presented in Chapter 5. 


\section{CHAPTER V \\ DISCUSSION}

The purpose of this final chapter is to summarize the findings and to relate those findings to current literature on child assessment and safety.

Summarization of data findings will be organized around change (reduced risk) and repeat maltreatment. Limitations, concluding comments and questions for future research will also be presented in this chapter.

The Adoption and Safe Families Act (ASFA) of 1997, P. L. 105-89, revolutionalized National Child Welfare Systems bringing unparalleled change and challenge. ASFA, built on over two decades of law and policy in child welfare, emphasizes that child safety is the chief consideration in decisionmaking regarding protective services for children. CFC's strategic plan, in line with ASFA, also emphasizes that the primary goal of CFC is to ensure that children and vulnerable adults are safe from harm (Kentucky Cabinet for Families and Children, 2003). Literature supports that evaluating the likelihood of maltreatment is a key decision in the child protective process (DePanfilis, 1996; English, 1998; Fuller, Well, \& Cotton, 2001; Haskett, Scott, \& Fann, 1995; McDonald \& Marks, 1991; Seaberg, 1988). 
Thus, one goal, and many would argue the most important goal, of assessment in child welfare is to gather and analyze information that will support sound decision-making regarding the safety of children. Christensen, Todahl, and Barrett (1999), emphasized that solution-based assessment is based on the principle that families have strengths that must be used to resolve the issues of concern. As such, assessment provides the foundation for subsequent service delivery and decisions, beginning with whether to substantiate a referral or find a family in need of services and continuing throughout the life of the case. Child welfare staff make complex decisions daily regarding child safety that deeply affect the lives of children and their families. Thus, workers must move from whether the family has complied with the plan, to whether the family is able to manage risk of harm at an acceptable level without agency involvement.

Hence, it is important to examine factors, which may help workers make better decisions about risk of harm and repeat maltreatment. This quantitative dissertation examined risk assessment and recidivism to determine if there was a relationship between child protective services provided by the Kentucky Department of Protection and Permanency and risk of harm. Risk of harm as measured by the CQA, repeat maltreatment and worker demographics were examined. Accepting that risk assessment is an ongoing process in child protective work and an individual's risk score should not be substituted for good clinical judgment in making casework decisions (Wald \& Woolverton, 1990), it is important to examine the tools that workers are using to guide their decisions. 
Thus this discussion of findings will begin with the Continuous Quality

Assessment Tool and its effectiveness in assessing risk.

\section{Continuous Quality Assessment Tool}

A replication of Huebner's (2002) factor analysis of the CQA, identified a safety factor that differed from the previous study of the tool. The Huebner safety factor included the CQA risk domains of maltreatment, adult patterns of behavior and sequence of events. The Mudd safety factor included the same domains with the addition of the family development domain. The Mudd safety factor was found to have an internal alpha coefficiency value higher than the Huebner safety factor. The Huebner well being factor included the CQA risk domains of family development, choice of discipline, child/youth development, and family support. The Mudd well being factor included the same domains with the omission of family development, which Mudd placed in the safety factor. Internal consistency for the well being factor was found to be below acceptable limits.

Solution-based casework is anchored around three tenets: (a) the commonality of challenges in family life, (b) the importance of focusing casework on those everyday life challenges that are high risk for families, and (c) the need to focus individual skill development on preventing relapse in high risk situations (Christensen, Todahl, \& Barrett, 1999). Thus, the inclusion of the family development stages and tasks domain in the safety factor is supported by the tenets that anchor the casework approach used in Kentucky. Further confirmation for the addition of the family development domain to safety was achieved by personal contact with Huebner. Huebner, Commonwealth of 
Kentucky researcher, reported that her later studies confirmed the addition of the family development domain to the safety factor.

Missing data and closing CQAs being scored higher (more risk) than opening CQAs, which had been identified as problems for Huebner's (2002) initial study of the CQA, were not problematic issues in current data. Only $6.3 \%$ of the cases were scored higher at closing than at opening. This does not appear to be a scoring issue of concern, as there are many reasons why a case could score higher at closing than opening, including new incident of maltreatment, additional information gained through course of casework, and the addition of new individuals to the home.

Examination of study findings revealed that high numbers of individual risk domains being scored " 0 " (no risk) was an issue. Family support, choice of discipline, and child development, domains of the Mudd well being factor, had scores of ' 0 " on $35 \%$ to $50 \%$ of the opening CQAs. An example of uncharacteristically low scoring was evidenced in the family support domain$35 \%$ of the study cases had a primary service program of neglect, yet nearly $93 \%$ of family support scores at closing indicated that lack of family support was not an issue. Thus, due to excessively low ratings in the well being factor and its less than acceptable internal consistency, the well being factor was not considered valid for this study.

Assessment is crucial at the point of case closure. In line with solutionbased concepts, this would be the point at which the family is able to manage their high-risk behaviors without agency intervention. Thus, closure may occur 
when there is reasonable expectation that the child will be safe and the family can manage any remaining risk of harm, with the assistance of their identified support system and community resources. To meet ASFA's accountability provisions, decisions about case closure need to be made in conjunction with the family and community partners and must be based on safety outcomes. This study found that at closing, $43.5 \%$ to $85 \%$ of risk domains were rated ' 0 '. Twenty-four percent of the closing cumulative CQA scores were ' 0 ' (no risk), with nearly $83 \%$ being rated in the low risk category. Huebner (2002) and the Kentucky's final CFSR report (U.S. Department of Health and Human Services, Children's Bureau, 2003) suggested that the low scoring of workers was indicative of an incident focused assessment, rather than the more desired comprehensive assessment. While there are undoubtedly many reasons for low scoring (indicating lack of risk), this researcher, as a state and federal CFSR reviewer, would suggest that workers are using the CQA to validate their decision to close cases, rather than as a tool to guide their decision making. Cases with moderate to high-risk ratings are being scrutinized closely at time of case closure; therefore, the low rating becomes a validation of the worker's decision and a means of circumventing additional scrutiny.

\section{CQA Conclusions}

It is clear that determining risk of harm within families is a complex and challenging endeavor. Therefore, further examination of the CQA tool is needed. There have been only limited tests of inter-rater reliability to determine whether two workers would score cases the same with the tool. Currently, the CQA is 
used throughout the life of the case and this often necessitates more than one worker completing an assessment on a case. Huebner (2002) concluded from her testing of the CQA that test-retest reliability was essential before trust could be placed in the scores. To increase reliability, efforts must continue toward solidifying the anchors to specifically identify events within each of the levels of risk. In particular the anchors and ratings for the well being factor should be examined and revised to increase their reliability.

The quality of casework decisions will be influenced by the validity of risk assessment tools used. As evidenced by the findings of this study, the CQA has strengths, as well as weaknesses. Accordingly, recognizing the inconsistencies in scoring, the lack of internal consistency of the well being factor, and the high number of '0" ratings can be used to improve Kentucky's risk assessment process. It may well be that the process of completing the CQA encourages workers to think about their clients' needs, which leads to improved service delivery. The CQA was described during the CFSR as a "useful process for assessing safety and risk" (U.S. Department of Health and Human Services, Children's Bureau, 2003). This study supports the CQA as being a valid tool for assessing safety and risk. However, the CQA's usefulness as an ongoing assessment tool, assessing behavioral changes throughout the life of the case, is not supported.

\section{Change}

According to Hudson (1988) the driving force behind the concept of service is change. Yet Carter (1988), after 10 years of studying social service programs, 
concluded that few programs were asking whether they were making a

difference. This study of protective service clients and change is directed toward answering the question, "Are we making a difference?"

\section{Confirmation of Change by Paired t-testing}

Paired t-testing, comparing changes in opening and closing CQA scores by Huebner safety factor, Mudd safety factor, and cumulative scores found significant differences $(p<.001)$, indicating that there had been a reduction in risk of harm. Pearson product-moment correlation testing indicated that the strongest associations between change in the CQA cumulative score and the individual risk domains were with maltreatment, sequence of events, family development, and adult patterns of behavior. These are the risk domains of the Mudd safety factor. Paired t-testing of the overall means, opening and closing, by program area and by region also showed significant differences $(p<.001)$ in all areas.

\section{Regional Differences in Change}

Examination of reduction in risk by individual regions revealed that some regions were doing a better job of reducing risk than others. Greatest differences between opening and closing CQA scores were in the FIVCO and Cumberland Valley regions (Appalachian Regions). The smallest reductions in risk scores were found in the Bluegrass Fayette region (Urban Region). Cumberland Valley, KIPDA Rural, KIPDA Jefferson, and Lake Cumberland regions had means of change (reduction in risk) above the state's overall mean of change, while their means of months of service were below the overall state mean. Thus their CQA 
scores and service times indicate higher reduction in risk in a less than average service time. Conversely, Bluegrass Rural, Bluegrass Fayette, Purchase, Green River, and Gateway Buffalo Trace regions had less than average means of change, while their service times were higher than the State's overall mean. Surprisingly, the highest percentages of risk reduction were in those regions classified as Appalachia. Regions with lowest percentages of reduction in risk were those having urban areas.

\section{Significant Relationships Between Independent Variables and Change}

Knowing we are making a difference is not enough; we also need to know for whom we are making a difference and how we are making a difference with those individuals. For the study cases, primary program of service, number of referrals in the case at time of case closure, and length of time case was open for treatment made a difference in the amount of risk reduction assessed.

Although, physical abuse and neglect cases were found to have higher percentages of significant risk reduction (over 7 CQA points), caution must be exercised in considering these findings, as programs of service were not mutually exclusive. Kinard (1994), and Howing, Woodarski, Kurtz, and Gaudin (1989) previously found the classification of maltreatment to be a methodological issue. They suggested that outcomes be viewed as cumulative. Accordingly, to gain a more thorough understanding of the effect of program of service, all service programs present throughout the life of study cases would need to be examined.

Confirming that cases with multiple referrals are complex and difficult for child protection workers to effectively manage, cases with higher numbers of 
referrals at closure had higher risk scores and less amount of change from opening to closing. Cases with over 3 referrals at time of case closure had the highest percentage $(22.7 \%)$ of cases scoring in the moderate to high risk categories at time of case closure and lowest percentage (33.6\%) of cases scoring over 7 points of CQA change from opening to closing. Cases with only 1 referral in them at case closure had the lowest percentage $(14.8 \%)$ of cases scoring in the moderate to high risk categories at time of case closure and highest percentage $(45.8 \%)$ of cases scoring over 7 points of CQA change from opening to closing.

The current data supported Cohn and DeGraff's (1982) finding that length of time in treatment is related to outcome. Time periods showing the greatest amount of change were 6 to 9 months and 12 to 18 months. Nearly $16 \%$ of cases open for 12 to 18 months scored 15 to 28 CQA points of risk reduction, while only $9.5 \%$ of cases open for less than 6 months scored an equal amount of risk reduction. Consequently, cases open for longer than 18 months also showed less amounts of risk reduction.

In summary, this study provides data, which enhances protection workers' understanding of how they are making a difference. With a million children a year being abused, child protective agencies are confronted with the need to understand assessment, risk and change. Variables, other than case manager/supervisor demographics, found to be related to change in Kentucky included (a) regional differences, (b) primary program of service, (c) number of referrals in case at closure, and (d) length of time case was open. Further 
research, examining each of the variables in greater depth, will be needed to understand how each of the identified variables uniquely contributes to change. Greater understanding of the variables related to change would allow interventions to be targeted toward those items, which improve or limit change.

\section{Case manager/Supervisor Demographics Related to Change}

As change is examined, it is important to understand how case manager demographics impact the outcome. Only supervisor gender and worker position were related to reduction in risk. Cases with male supervisors closed with slightly higher levels of assessed risk than those with female supervisors. Reduction in risk was higher with those classified with higher levels of expertise. Thus, current data supports Cohn and DeGraff's (1982) finding that workers with more years of child abuse and neglect experience were more successful in achieving desired outcomes.

Workers' having social work degrees was not significantly related to reduction in risk. However, since $73.6 \%$ of the cases were managed by workers with degrees recognized by COA as meeting the standard for child protective work, the importance of a degree in social work may be lessened. In addition, Kentucky's training for child protective workers was found to be in substantial conformity during the Federal CFSR (U.S. Department of Health and Human Services, Children's Bureau, 2003). Kentucky's final CFSR report was highly complementary of the Permanency and Protection Training Academy that all protection workers attend during their first 3 months of employment. Thus, 
having a social work degree may be less important, in light of the extensive training provided for new employees.

\section{Repeat Maltreatment}

Ultimately, the effectiveness of decision-making and service delivery is measured by the recurrence or lack of recurrence of maltreatment. Thus, most would agree with DePanfilis (1996) that the primary purpose of child protective agencies offering services to children and families after reports of abuse or neglect have been substantiated is to prevent the reoccurrence of maltreatment. Sadly, however, Cohn and Daro (1987), who reviewed data on 3,253 families involved in 89 treatment programs, found that one-half of parents were likely to reabuse following case closure. This is evidenced in the current population, as 1 out of every 2 cases in the study population had previously received services from CFC.

The percentage of recurrence of maltreatment (in the study population) since the most recent case closure, however, is much lower than the $50 \%$. The mean length of time between the prior case closing and reopening for current episode of treatment was 10.7 months. Reviewing the frequency of length of time between prior case closing and reopening for current treatment episode, over $75 \%$ of the cases had been reopened by 16 months. Considering the current population from the time of case closure through June 2003 (12 to 16 months), only $12 \%$ of the cases have had a substantiated incident of maltreatment. Even with inclusion of unsubstantiated referrals, the percentage of recurrent maltreatment is much less than the $50 \%$. From the time of case 
closure to June 2003 slightly more than one-fourth $(n=758)$ of the cases have had a new referral.

\section{Regional Differences in Repeat Maltreatment}

Examination of repeat maltreatment by region revealed that Fivco (18.3\%) and Kentucky River regions (16.2\%) had the highest percentages of substantiated recurrent maltreatment following case closure. Ironically, Fivco and Kentucky River regions had means of reduction in risk (opening to closing CQA) above the state's overall mean. Thus, amount of risk reduction was not predictive of repeat maltreatment. Further examination of the data showed that Fivco region had the second highest opening CQA mean and the second lowest closing CQA mean in the state. Kentucky River region also had one of the higher opening CQA means. Therefore, these regions with high opening CQA risk scores had high rates of repeat maltreatment. Lowest percentages of substantiated recurrent maltreatment were found in Pennyrile $(7.1 \%)$ and Gateway/Buffalo Trace regions (9.1\%). Pennyrile and Gateway/Buffalo Trace regions had means of reduction in risk below the state's overall mean. Again, amount of risk reduction was not predictive of repeat maltreatment. Gateway/Buffalo Trace region had the second lowest opening CQA mean in the state. Pennyrile region also had a lower opening CQA mean. Hence, regional differences highlight that opening CQA scores are more predictive of recidivism than closing CQA scores.

Significant Relationships Between Independent Variables and Repeat

\section{Maltreatment}


Variables found to have a significant association with substantiated repeat maltreatment included, Mudd safety factor, CQA risk domains, number of referrals in case at closure, prior episode of treatment, and workers years of service. Examination of the Mudd safety scores and risk domains of the CQA supports that opening CQA scores are more predictive of repeat maltreatment than closing scores. Although, significant relationships were found between substantiated maltreatment following case closure and (a) closing Mudd safety factor score, (b) opening CQA risk domain scores for sequence of events, family development, and family support, and (c) closing CQA scores for sequence of events, family development, and adult patterns of behavior, the findings were mixed. As expected, the percentage of cases having a new referral following case closure was smaller for those having the lowest cumulative CQA scores at opening (0-6). Those having the lowest opening Mudd safety scores also had fewer new referrals following case closure. The closing cumulative CQA scores and closing safety factor scores; however, were not predictive of repeat maltreatment. Low closing Mudd safety scores had higher percentages of substantiated repeat maltreatment than those with high closing Mudd safety scores and low closing cumulative CQA scores had higher percentages of cases with new referrals. Excessive low scoring at closing is undoubtedly one explanation for the mixed findings between CQA scores and repeat maltreatment. At closing, $43.5 \%$ to $85 \%$ of risk domains were rated ' 0 ." Another explanation for the mixed findings may be that different individuals completed the opening and closing CQAs, and as a result some inconsistency in scoring may 
be present. The consistency of scoring is an area that needs to be examined more closely.

A review of the CQA risk domains and their associations with recurrent maltreatment shows similar issues - too many domains rated ' 0 ' and high and low percentages across the 5-point scale that are not sequential by level of identified risk. On the other hand, as evidenced by review of the individual risk domain scores, the individual scores may be as important in determining recurrent maltreatment, as the total score. Fuller, Wells, and Cotton (2001) cautioned against simply summing the number of risk factors, reporting that the interaction of risk factors was too important to discount. A review of opening sequence of events scores shows that the highest percentage of substantiated repeat maltreatment was found in cases with a sequence score of ' 2 ' at opening. A review of the anchors for sequence ' 2 ' revealed that one of the anchors is inconsistent parenting. Inconsistent parenting would be only one explanation for the mixed findings and increased recidivism in the ' 2 ' category of sequence of events. Interestingly, the opening maltreatment ' 2 ' category also had the most recidivism and substantiated maltreatment. A review of the anchors for maltreatment ' 2 ' showed that many of the anchors highlight patterns of chronic neglect.

Fuller, Wells, and Cotton (2001) found that type of maltreatment was a predictor for short-term recurrence of child abuse/neglect. Although, neglect and physical abuse had the highest percentage of referrals following case closure, current data did not support that these programs had a significant association to 
substantiated maltreatment. The methodological issue of program of service not being mutually exclusive prohibits a full understanding of service programs' relationships to repeat maltreatment. Accordingly, the cumulative nature of abuse/neglect would require that all service programs present throughout the life of cases be examined for contribution to relationship.

Current data supported Claburn, Magura, and Chizeck (1977) and Fuller, Wells, and Cotton's (2001) findings that a prior episode of treatment was significantly related to substantiated maltreatment following case closure. Fifteen percent of those with a prior treatment episode had a substantiated incident of maltreatment after case closure, while only $8.8 \%$ of those without a prior episode of treatment had a new substantiated incident.

As with reduction in risk, current data supported that cases with multiple referrals are complex and difficult for child protection workers to effectively manage. Cases with higher numbers of referrals at closure had higher numbers of substantiated referrals following case closure.

\section{Case manager/Supervisor Demographics Related to Repeat Maltreatment}

Case manager demographics significantly related to recidivism were worker position and years of service. Position was significantly related to reports of maltreatment received after closure (substantiated and unsubstantiated), while worker years of experience had a significant relationship with substantiated maltreatment. Current data on reports received after case closure supports Cohn and DeGraff's (1982) finding that workers with more years of child abuse and neglect were more successful in achieving desired outcomes. Twenty-nine 
percent of cases managed by workers had new referrals, while only $23 \%$ of those managed by clinicians had new referrals. Thus, cases having case managers with more expertise had fewer reports of maltreatment following case closure. Workers with more than 5 years of experience; however, were more likely to have cases with substantiated maltreatment following case closure. One explanation for the more experienced staff having higher substantiated maltreatment would be that in line with their higher expertise, their case assignments are more complex and difficult to manage.

\section{Limitations}

The limitations of this study are those commonly associated with retrospective studies and secondary analysis. Complete information was not available about all families and workers. As most of the data were collected from electronic case records, COA management and TWIST reports, the researcher had little control over the thoroughness and quality of the original information. While these issues had been monitored through supervisory review and Kentucky's continuous quality improvement process, there were variations in the quantity and quality of individual case records.

The majority of the data being nominal or ordinal was a significant statistical limitation that placed restrictions on data analysis. Considerable data reduction was needed to enhance the manageability of the data. Data reduction led to loss of specificity in some categories. The infancy of the CQA tool contributed to 406 cases being eliminated from the study population. Cases eliminated from the study included (a) ' 0 " ratings for opening cumulative scoring 
and (b) opening and closing CQAs completed on the same day. For cases eliminated, the mean from the time case was open until the first CQA was completed was over 20 months. Over half of the cases had been open longer than 2 years, with $25 \%$ of the group being open over 4 years. Hence, many of the cases were opened prior to the development of the CQA.

\section{Concluding Comments on Assessment, Change, and Recidivism With}

\section{Suggestions For Future Studies}

Even with the limitations recognized, this study has significant implications for risk assessment. Based on a review of the literature, the use of a risk assessment protocol and risk assessment tool improves decision-making. Given the numerous problems with implementing risk assessment processes within child public child welfare agencies, it is helpful to be able to isolate a small set of factors that help workers understand change and determine which families are most likely to have recurrent maltreatment.

\section{CQA Tool}

As evidenced by the findings of this study, the CQA has strong points, as well as limitations. Current data supports the CQA as being a valid tool for assessing safety and risk-the opening CQA scores being more predictive of repeat maltreatment than the closing scores. The CQA's usefulness as an ongoing assessment tool, assessing behavioral changes throughout the life of the case, is not supported. The soundness of assessment decisions will be influenced by the validity of the risk assessment tool used. Accordingly, recognizing the inconsistencies in scoring, the lack of internal consistency of the 
well being factor, and the high number of ' 0 " ratings, can be used to improve Kentucky's risk assessment process.

Suggestions for improving the CQA include: (a) complete inter-rater reliability testing, (b) solidify anchors by using inter-rater testing to identify recognized behavioral indicators for each risk domain, (c) increase worker inter rater reliability by incorporating CQA anchor selection (hands on activities) into new and ongoing worker/supervisory training (d) develop an ongoing assessment that focuses on behavioral changes in the family, and (e) increase supervisory scrutiny of all risk domains scored '0.' Despite limitations, if the methodological issues identified are addressed and the validation research is conducted, the potential for the CQA to guide workers in decision-making is excellent.

\section{Change}

This study of protective service clients and change was directed toward answering the question, "Are we making a difference?" Current data supports that families served by Kentucky Protection and Permanency experienced significant reductions in risk from opening to closing CQA. The investigative responsibility of the protective service agency predisposes protective service workers to focus on whether abuse/neglect occurred rather than on the sequence of events that led to the occurrence of the abuse. To help families learn to manage high-risk behaviors, workers must understand how the abuse occurred (sequence of events). Likewise, protective service agencies must not be content with knowing if they have made a difference, but rather must ask the more inclusive question of how they made a difference. 
Current data supports that number of referrals in the case at time of case closure, supervisor gender, expertise of worker, and length of time case was open for treatment made a difference in the reduction of risk assessed. To more clearly understand risk reduction in Kentucky protective service families, additional studies are needed on: (a) regional differences, (b) type of abuse (including cumulative history of abuse), (c) length of service time for optimal risk reduction, and (d) quality of service delivery (number of face to face visits, quality of case plan, etc.).

Suggestions for improving management and measurement of risk include: (a) identify high risk situations on all case plans to emphasize that risk reduction occurs as families develop skills in managing high risk behaviors, (b) increase emphasis on using risk assessment as the basis for the development of specific risk related case plans, (c) create an ongoing CQA which assesses behavioral changes in the family throughout the life of the case, (d) use the CQA to guide decisions, rather than to validate predetermined courses of action, (e) avoid premature or excessive delays in case closures by discussing length of time case has been open at all case reviews, and ( $f$ ) assign cases with high CQA safety ratings to clinicians (workers with higher years of service and/or expertise).

\section{Recidivism}

If one accepts the premise that the effectiveness of decision-making and service delivery is measured by the recurrence or lack of recurrence of maltreatment, then Kentucky's child protective services are making a difference. Only $12 \%$ of the study cases have had a substantiated incident of maltreatment 
in the 12-16 months since their closure. Recidivism rose sharply during the first 90 days the case was closed, and then slowly decreased over the following 10 months. Cases with high numbers of referrals and/or prior episodes of treatment were found to have a significant relationship to repeat maltreatment. To more clearly understand recidivism in Kentucky, current data indicates additional studies are needed on regional differences and type of abuse (including cumulative history of abuse).

Suggestions for limiting recidivism include: (a) focus aftercare planning on relapse prevention, (b) increase worker competency in developing relapse prevention plans by adding relapse prevention to new and ongoing worker/supervisory training, (c) conduct family team meetings (including community service providers) at case closure to wrap services around family, with particular focus on families' high risk situations and behaviors, (d) teach families to use solution based relapse prevention skills to manage their high risk times (identifying high risk times and warning signals, and utilizing skills to avoid, interrupt, or escape risk situations), (e) assign cases with high numbers of referrals and prior episodes of treatment to workers with higher expertise, and (f) increase supervisory scrutiny of cases with high CQA safety ratings at case opening.

\section{Effectiveness in Kentucky?}

In 1973, Fischer challenged the social work profession to demonstrate effectiveness. Kentucky children and families deserve no less than the agency's best in taking on the challenge of demonstrating effectiveness. Kentucky has 
moved from a system that was largely punitive to one that elevates partnerships. Subsequently, change is occurring and recurrent maltreatment has been reduced. Is Kentucky where it needs to be in assessment, service delivery, and aftercare planning? Absolutely not. Workers, researchers, and agency administrators must constantly strive to improve and demonstrate effectiveness. This study of risk assessment will add to the body of knowledge on measurable outcomes, which will enhance Kentucky's ability to improve service delivery to the families and children of Kentucky. One must always be cognizant that children's' safety, permanency, and well being are the outcomes upon which the effectiveness of the protective service agency will ultimately be judged. 


\section{REFERENCES}

Action for Child Protection, Inc. (2003, May 8). Action is the child safety intervention organization. Retrieved May 8, 2003 from http://www.actionchildprotection.org/home.html.

Adoption And Safe Families Act, P. L. 96-276; [S. 101]. (1981). United States Code Congressional and Administrative News: 96th Congress-Second Session 1980 (Vol. 3.). St. Paul, MN: West Publishing Co.

Adoption Assistance and Safe Families Act, P. L. 105-89; 111 STAT. 2126 [S. 202]. (1998). United States Code Congressional and Administrative News: 105th Congress-First Session 1997 (Vol. 2.). St. Paul, MN: West Publishing Co.

Alexander, L., \& Siman, A. (1973). Fischer's study of studies. Social Work, 18, $597-602$.

Alperin, D. (1993). Family service agencies: Responding to need in the 1980s. Social Work, 38, 597-602.

Anderson, P. (1989). The origin, emergence, and professional recognition, of child protection. Social Service Review, 63, 222-244.

Antler, J., \& Antler, S. (1979). From child rescue to family protection. Children and Youth Services Review, 1, 177-204. 
Beck, D. F., \& Jones, M. J. (1973). Progress on family problems. New York, NY: Family Service Association of America.

Beck, U. (1992). Risk society: Towards a New Modernity. Thousand Oaks, CA: Sage.

Berg, I. K. (1994). Family based services-a solution-focused approach. New York, N Y: W.W. Norton \& Company, Inc.

Berleman, W., Seaberg, J., \& Steinburg, T. (1972). The delinquency prevention experiment of the Seattle Atlantic street: A final evaluation. Social Service Review, 46, 323-346.

Blythe, B. J. (1983). Critique of outcome evaluation in child abuse treatment. Child Welfare, 62(4), 325-335.

Briar, S. (1968, January). The casework predicament. Social Work, 13, 5-11. Briar, S. (1973). The age of accountability [Editorial]. Social Work, 18, 114.

Brown, J. (1975). Research by practitioners. (Letter) Social Work, 20, 501.

Campbell, D. T., \& Stanley, J. C. (1963). Experimental and quasi-experimental designs for research. Boston, MA: Houghton Mifflin Company.

Carstens, C. C. (1915). Report of the committee: A community plan in children's work. Proceedings of the National Conference of Charities and Corrections, 42, 92-106.

Carter, R. K. (1988). Measuring client outcomes: The experience of the states. Administration of Social Work, 11(3/4), 73-88.

Chambers, D. (1993). Social policy and social programs ( $2^{\text {nd }}$ ed.). Needham Heights, MA: Allyn \& Bacon. 
Child Abuse Prevention and Treatment Act, Public Law 93-247; 88 STAT. 4, [S.

1191]. (1975). United States Code Congressional and Administrative News:

93rd Congress--Second Session 1974 (Vol. 1). St. Paul, MN: West

Publishing Co.

Child Welfare League of America. (2003). National child abuse and neglect data system. Retrieved May 20, 2003, from

(http://ndas.cwla.org/Default.asp?Mode=0).

Christensen, D., \& Todahl, J. (1996). Preventing relapse in family casework: A solution based approach to practice. Unpublished manuscript, University of Louisville at Louisville, $\mathrm{KY}$.

Christensen, D., Todahl, J., \& Barrett, W. (1998). Casework skills: Searching for solutions in a post-modern world. Unpublished manuscript, University of Louisville at Louisville, KY.

Christensen, D., Todahl, J., \& Barrett, W. (1999). Solution based casework: An introduction to clinical and case management skills in casework practice. New York: Walter de Gruyter.

Claburn, W. E., Magura, S., \& Chizeck, S. P. (1977). Case reopening: An emerging issue in child welfare services. Child Welfare, 56(10), 655-663.

Cohn, A. H., \& Daro, D. (1987). Is treatment too late: What ten years of evaluative research tell us. Child Abuse and Neglect, 11(3), 433-442.

Cohn, A. H., \& DeGraff, B. (1982). Assessing case management in the child abuse field. Journal of Social Service Research, 5(1/2), 29-43. 
Costin, L. (1991). Unraveling the Mary Ellen legend: Origins of the "cruelty" movement. The Social Service Review, 65(2), 203-23.

Costin, L. (1992). Cruelty to children: A dormant issue and its rediscovery, 19201960. Social Service Review, 66(2), 177-98.

Council on Accreditation for Children and Family Services, Inc. (2001).

Standards and self-study manual (7th ed.). Public organizations. New York: Council on Accreditation.

Craig, M., \& Furst, P. (1965). What happens after treatment? A study of potentially delinquent boys. Social Service Review, 39, 165-171.

Dattalo, P. (1995). A topology of child protective services cases based on client presenting problems. Journal of Social Service Research, 21(2), 55-70.

DePanfilis, D. (1996). Implementing child maltreatment risk assessment systems: Lessons from theory. Administration in Social Work, 20(2), 4159.

DePanfilis, D., \& Salus, M. K. (1992). A coordinated response to child abuse and neglect: A basic manual. DHHS Publication No. (ACF) 92-30362. McLean, VA: The Circle Inc.

DePanfilis, D., \& Zuravin, S. J. (2001). Assessing risk to determine the need for services. Children and Youth Services Review, 23(1), 3-20.

Ell, K. (1996). Social work and health care practice and policy: A psychosocial research agenda. Social Work, 41, 583-592.

English, D. (1998). The extent and consequences of child maltreatment. The Future of Children, 8(1), 39-52. 
English, D. J., Marshall, D. B., Brummel, S. C., \& Coghlan, L. K. (1998).

Decision making in child protective services: A study of effectiveness. Olympia, WA: Washington Department of Social and Health Services.

Ferguson, H. (1997). Protecting children in new times: Child protection and the risk society. Child and Family Social Work, 2(4), 221-234.

Filip, J., McDaniel, N., \& Schene, P. (Ed.) (1992). Helping in child protective services: A competency-based casework handbook. Englewood, CO: American Humane Society.

Fischer, J. (1973a). Is casework effective? A review. Social Work, 18, 5-20.

Fischer, J. (1973b). Has mighty casework struck out? Social Work, 18, 107-110.

Flexner, A. (1915). Is social work a profession? In Proceedings of the National Conference on Charities and Corrections, 1915, (pp. 558-562). Chicago: University of Chicago Press.

Folks, H. (1899). Comments to the ninth session national conference of charities and corrections, May 23, 1898. In I. Barrows, ed., Proceedings of the National Conference of Charities and Corrections (p. 184-191). Boston, MA: George H. Ellis.

Folks, H. (1902). Care of destitute, neglected, and delinquent children. New York: Macmillan.

Freeman, E. M. (1995). Welfare reforms and services for children and families: Setting a new practice, research, and policy agenda. Social Work, 41(5), $521-532$. 
Fuller, T. L., Wells, S. J., \& Cotton, E. E. (2001). Predictors of maltreatment recurrence at two milestones in the life of the case. Children \& Youth Services Review 23(1), 49-78.

Gambrill, E., \& Shlonsky, A. (2001). The need for comprehensive risk management systems in child welfare. Children \& Youth Services Review 23(1), 79-107.

Gane, E. (1947). Discussion. In Proceedings of the National Conference of Social Work: Selected Papers. Seventy-fourth Annual Meeting, April 1319, 1947 (p. 316). New York: Columbia University Press.

Garbarino, J. (1984). What have we learned about child abuse and neglect? In U.S. Department of Health and Human Services, NCCAD (ed.), Perspectives on child maltreatment in the mid 80's. (OHDS) 84-30338. Washington, D.C.: U.S. Government Printing Office.

Gaudin, J.M., Polansky, N. A., \& Kilpatrick, A. C. (1992). The child well-being scales: A field test. Child Welfare 71(4), 319-328.

Geismar, L., \& Krisberg, J. (1966). The family life improvement project: An experiment inn preventative intervention: Part 1. Social Casework, 47, $563-570$.

Gerry, E. T. (1913). The relations of the society for the prevention of cruelty to child saving work. In Proceedings of the National Conference of Charities and Corrections, 1882 (p. 129-130). Fort Worth, IN: Ft. Worth Printing Company. 
Giddens, A. (1994). Beyond left and right: The future of radical politics.

Cambridge, MA: Polity press.

Giovannoi, J. M. (1982). Prevention of child abuse and neglect; research and policy issues. Social Work Research and Abstract, 18(3), 23-31.

Goldman, J., \& Salus, M. (2001). A coordinated response to child abuse and neglect: The foundation for practice. HHS Publication No. 282-98-0025. Retrieved May 20, 2003, from http://www.calib.com/nccanch/pubs/usermanuals.cfm.

Gordon, H. (1946). The place of authority in the protective function of the public welfare agency. CWLA Bulletin, 25, September.

Gough, D. (1996). Defining the problem. Child Abuse \& Neglect, 20(11), 9931002.

Graycarek, R., \& Hoye, K. (2002). 2000 Kentucky child poverty: One in five children is poor (Kentucky Youth Advocates Census Brief Vol. 2). Retrieved September 8, 2003, from http://www.kyyouth.org/Publications/census/poverty-kh09.pdf

Grinnell, R. (1997). Social work research \& evaluation. Itasca, IL: F. E. Peacock Publishers.

Gyarfas, M., \& Nee, R. (1973). Was it really casework? Social Work, 18, 3-4. Hampton, R. L., \& Newberger, E. H. (1985). Child abuse incidence and reporting by hospitals: Significance of severity, class, and race. American Journal of Public Health, 75(1), 56-60. 
Hasket, M. E., Scott, S. S., \& Fann, K. D. (1995). Child abuse potential inventory and parenting behavior: Relationships with high-risk correlates. Child Abuse \& Neglect, 19(12), 1483-1495.

Holder, W., \& Corey, M. (1987). Child protective services risk management: A decision making handbook. Charlotte, NC: ACTION for Child Protection. Holder, W., Costello, T, Lund, T. R., \& Holder, T. (2000). SAFE: Safety assessment and family evaluation. Charlotte, NC: ACTION for Child Protection.

Howing, P. T., Wodarski, J. M., Gaudin, J. M., \& Kurtz, P. D. (1989). Effective interventions to ameliorate the incidence of child maltreatment: The effective base. Social Work, 34(4), 330-38.

Howing, P. T., Wodarski, J. M., Kurtz, P. D., \& Gaudin, J. M. (1989).

Methodological issues in child maltreatment research. Social Work Research and Abstracts, 25(3), 3-5.

Hudson, W. (1974). Casework as a causative agent in client deterioration. Social Service Review, 48, 442-449.

Hudson, W. (1988). Measuring clinical outcomes and their use for managers. Administration in Social Work, 11(3/4), 59-71.

Huebner, R. (2002, April). Evaluation of the continuous quality assessment tool.

Paper presented at the Continuous Quality Assessment Workgroup Meeting, Frankfort, KY. Johnson, W., \& L'Esperance, J. (1984). Predicting the recurrence of child abuse. Social Work Research \& Abstracts, 20(2), 21-26. 
Kadushin, A. (1978). Child welfare strategy in the coming years: An overview. In Child welfare in the coming years. Washington, DC: U.S. Department of Health, Education, and Welfare.

Kadushin, A. (1980). Child Welfare Services $3^{\text {rd }}$ ed. New York, NY: Macmillan. Kentucky Cabinet for Families and Children. (2003a, January). Commonwealth of Kentucky Child and Family Services Statewide Assessment. Report submitted to U.S. Department of Health and Human Services during Children and Families Service Review, Kentucky.

Kentucky Cabinet for Families and Children. (2003b). Kentucky Department of Protection and Permanency Operations Manual. Retrieved May 20, 2003, from http://cfc.state.ky.us/pandp_process/.

Kentucky Kids Count Data Book. (2003). Retrieved September 8, 2003, from Annie E. Casey Foundation Website: http://www.aecf.org/kidscount/databook/

Kentucky Legislative Research Commission. (2003). Kentucky Revised Statutes. Retrieved January 18, 2004, from http://www.Irc.state.ky.us/krs/titles.htm. Kinard, E. M. (1994). Methodological issues and practical problems in conducting research on maltreated children. Child Abuse and Neglect 18(8), 645-656.

Kinnear, P. R., \& Gray, C. D. (1992). SPSS/PC made simple. Hove (UK): Lawrence Erlbaum Associates.

Kirk, S. A. (1991). Scholarship and the professional school. [Editorial]. Social Work Research and Abstracts, 27(1), 3-5. 
Levitt, E. (1957). The results of psychotherapy with children: An evaluation. Journal of Consulting Psychology, 21, 189-196.

Likert, R. (1932). A technique for measurement of attitudes. Archives of Psychology, 150, 55.

Lincoln, A. N. (1898). Classification of paupers. In I. Barrows (Ed.), Proceedings of the National Conference of Charities and Corrections (p. 184-191). Boston, MA: George H. Ellis.

Lyons, P., Doueck, H. J., Koster, A. J., Witzky, M. K., \& Kelly, P. L. (1999). The child well-being scales as a clinical tool and management information system. Child Welfare 78(2), 241-258.

Macdonald, K. I., \& Macdonald, G. M. (1999). Perceptions of risk. In P. Parsloe (Ed.), Risk assessment in social care and social work: Research highlights. Philadelphia, PA: Jessica Kingsley.

Magura, S. (1982). Clients view outcomes of child protective services. Social Casework, 63(9), 522-31.

Magura, S., \& Moses, B. S. (1980). Outcome measurement in child welfare. Child Welfare, 59(10), 595-606.

Magura, S., \& Moses, B. S. (1984). Clients as evaluators of child protective services. Child Welfare, 63(2), 99-112.

Magura, S., \& Moses, B. S. (1986). Outcome measures in child welfare services: Theory and applications. Washington, DC: Child Welfare League of America. 
Maluccio, A. N. (1979). Perspectives of social workers and clients on treatment outcome. Social Casework, 60(July), 394-401.

Mary Ellen Wilson. (1874, April 14). The New York Times, p. 2.

McCurdy, K. (1995). Risk assessment in child protective services. Social Work Research 19(2), 77-88.

McDonald, T., \& Marks, J. (1991). A review of risk factors assessed in child protective services. Social Service Review, 65(1), 112-132.

Middleman, R., \& Goldberg, G. (1972). The interactional way of presenting generic social work concepts. Social Work, 8, 48.

Middleman, R., \& Goldberg, G. (1974). Social service delivery: A structural approach to social work practice. New York: Columbia Press

Miller, W. (1957). The impact of a community group work program on delinquent corner groups. Social Service Review, 31, 390-406.

Miller, H. (1968). Value dilemmas in social casework. Social Work, 13, 42-52.

Nasuti, J., (1998). Risk assessment in child protective services. Journal of Family Social Work, 3(1), 55-70.

Nasuti, J., \& Pecora, P. (1993). Risk assessment scales in child protection: A test of the internal consistency and interrater reliability of one statewide system. Social Work Research \& Abstracts, 29(2), 28-33.

Nelson, K. E., Saunders, E. J., \& Landsman, M. J., (1993). Chronic child neglect in perspective. Social Work, 38(6), 661-670.

Olson, I. (1970). Some effects of increased aid in money and social services to families getting AFDC. Child Welfare, 49, 94-104. 
Patti, R. (1985). In search of purpose for social welfare administration.

Administration in Social Work 9(3), 1-4.

Pecora, P. J. (1989). Evaluating risk assessment systems-methodological issues and research findings. In P. Schene \& K. Bond (Eds.), Research issues in risk assessment for child protection (pp. 47-59). Denver, CO: American Association for Protecting Children.

Pecora, P. J., Fraser, M. W., Nelson, K. E., McCroskey, J., \& Meezan, W. (1995). Evaluation family based services. New York: Aldine De Gruyter.

Rapp, C. A., Hardcastle, D. A., Rosenzweig, J., \& Poertner, J. (1983). The status of research in social service management. Administrative in Social Work 7(3), 89-100.

Rapp, C. A., \& Poertner, J. (1988). Moving clients center stage through the use of client outcomes. New York: Haworth Press, Inc.

Reid, J. H. (1979). Child welfare perspectives. New York: Child Welfare League of America, Inc., 1979.

Reid, W. J. (1988). Service effectiveness and the social agency. In R. Patti (Ed.), Managing for service effectiveness in social welfare organizations (pp. 4158). New York: Haworth Press, Inc.

Reid, W., \& Shyne, A. (1969). Brief and Extended Casework. New York: Columbia University Press.

Rubenstein, H., \& Bloch, M. H. (1978). Helping clients who are poor: Worker and client perceptions of problems, activities, and outcomes. Social Service Review 52(March), 69-84. 
Rubin, A., \& Babbie, E. (Eds.) (1997). Research methods for social work (3 ${ }^{\text {rd }}$ ed.). Pacific Grove: CA: Brooks/Cole Publishing.

Seaberg, J. R. (1988). Child well-being scales: A critique. Social Work Research \& Abstracts, 24(3), 9-15.

Seaberg, J. R. (1990). Child well being: A feasible concept. Social Work, 35(3), 267-272.

Shapiro, D. (1979). Parents and protectors. New York: Child Welfare League of America.

Shireman, J. E., Grossnickle, D., Hinsey, C., \& White, J. (1990). Outcome study of protective services: Comparison of interviews and records in data sources. Child Welfare 69(2), 167-79.

Specht, H. (1968). Casework practice and social policy formulation. Social Work, 13(January), 42-52.

Thomas, M. P. (1972). Child abuse and neglect: Part 1. Historical overview, legal matrix, and social perspectives. North Carolina Law Review, 50, 293-349.

U. S. Census (2000). Census 2000 Data for the State of Kentucky. Retrieved September 8, 2003, from http://www.census.gov/census2000/states/ky.html.

U.S. Department of Health and Human Services. (2000). Rethinking child welfare practice under the Adoption and Safe Families Act of 1997: A resource guide. Washington, DC: U.S. Government Printing Office. 
U.S. Department of Health and Human Services, Administration on Children, Youth and Families. (2001). Child maltreatment 1999: Reports from the states to the National Child Abuse and Neglect Data System.

Washington, DC: U.S. Government Printing Office.

U.S. Department of Health and Human Services, Administration on Children, Youth and Families. (2003). Child maltreatment 2001: Reports from the states to the National Child Abuse and Neglect Data System.

Washington, DC: U.S. Government Printing Office.

U.S. Department of Health and Human Services, U.S. Advisory Board on Child Abuse and Neglect. (1993, April). The continuing child protection emergency: A challenge to the nation. Washington, D.C.: Author.

U.S. Department of Health and Human Services, Children's Bureau (2003). Child and Family Service Review: Kentucky Final Report. Retrieved February 1, 2004, from (http://www.acf.dhhs.gov/programs/cb/cwrp/cfsr.htm).

Videka-Sherman, L., \& Viggiani, P. (1996). The impact of federal policy on children: Research needs for the future. Social Work, 41, 594-600.

Wald, M. S., \& Woolverton, M. (1990). Risk assessment: The emperor's new clothes? Child Welfare 69(6), 483-511.

Watkins, S. (1990). The Mary Ellen myth: Correcting child welfare history. Social Work, 35, 500-503.

Webb, A., \& Riley, P. (1970). Effectiveness of casework with young female probationers. Social Casework, 51, 566-572. 
Wells, S. J. (1994) Child protective services: Research for the future. Child Welfare, $L X X I I /(5), 431-447$.

Wilkinson, K., \& Ross, P. (1972). Evaluation of the Mississippi A.F.D.C.

Experiment. Social Service Review, 46(September), 363-377.

Winefield, H. R., \& Barlow, J. A. (1995). Client and worker satisfaction in a child protection agency. Child Abuse \& Neglect, 19(8), 897-905.

Wolfe, D. (1985). Child-abusive parents: An empirical study and analysis. Psychological Bulletin, 97(3), 462-482.

Wood, K. (1978). Casework effectiveness: A new look at the research. Social Work, 46, 437-458.

Wulezyn, F. H., \& George, R. M. (1992). Foster care in New York and Illinois: The challenge of rapid change. Social Service Review, 66(2), 278-294. 


\section{Appendix A}

\section{Continuous Quality Assessment \\ Directions for Completion, Form, Anchors}

\section{Familial Perpetrators}

The Continuous Quality Assessment guides the workers in the collection, organization and analysis of information to better determine the safety, risk and needs of the families and children served through a consistent statewide assessment process. The CQA contains the following sections in TWIST: Maltreatment / Presenting Problem

- Abuse / Neglect Conditions

- CPS Ratings and Anchors

- Sequence of Events

- Safety Screening Checklist

- Family Developmental Stages and Tasks

- Family Choice of Discipline

- Adult Patterns of Behavior

- Child / Youth Development

- Family Support

- Summary Screens

\section{Non-familial Perpetrators}

Reports that have a non-familial out of home perpetrator may use an abbreviated version of the assessment. The abbreviated assessment shall include:

- Maltreatment / Presenting Problem; 
- Sequence of Events;

- Abuse / Neglect Conditions; and

- Summary Screens.

\section{Timeframes for Completion of the CQA}

1. The CQA is completed by the worker on every referral (CPS, Status, General Family). For the purpose of the Continuous Quality Assessment, familial is defined as anyone who has continuous access to the child in a home environment. Examples include boyfriends, extended family members, babysitters, etc.

2. If risks are identified at the time of the investigative visit, the worker completes the Family's Safety Plan or Personal Safety Plan.

3. The investigative workers shall complete the CQA (a) within 30 working days of a report on all referrals and (b) prior to transferring to ongoing services. The CQA shall be completed by the ongoing workers (a) prior to a case plan; (b) a minimum of every six months; (c) when significant changes occur in the family; and (d) prior to case closure.

4. If a case plan is needed prior to the completion of the initial CQA, the case plan may be developed prior to the completion of the CQA, however, the case plan cannot be submitted for supervisory approval until the CQA has been completed and submitted.

5. If a new referral is received after the case has been opened for ongoing services, the new referral shall have a new CQA. 
case plan cannot be submitted for supervisory approval until the CQA has been completed and submitted.

5. If a new referral is received after the case has been opened for ongoing services, the new referral shall have a new CQA.

6. When a new referral is received more than 30 days after the first referral, the worker may, with supervisory approval, may use the information from the previous CQA to assist in completing the CQA.

7. In addition to the CQA, the investigative summary and results screens in TWIST shall be completed when the CQA is being utilized for a new referral. (Kentucky Cabinet for Families and Children, 2003). 


\title{
COMMONWEALTH OF KENTUCKY CABINET FOR FAMILIES AND CHILDREN DEPARTMENT FOR COMMUNITY BASED SERVICES
}

\author{
CONTINUOUS QUALITY ASSESSMENT \\ Investigative or Ongoing- CPS NARRATIVE OUTLINE
}

\section{Date CQA Approved:}

I. MALTREATMENT/PRESENTING PROBLEM: What is the extent of the maltreatment? Collateral/witness description of maltreatment.

\section{Narrative:}

\begin{tabular}{|c|}
\hline $\begin{array}{c}\text { Maltreatment } \\
\text { Rating }\end{array}$ \\
\hline$(0-4)^{*}$ \\
\hline
\end{tabular}

*See Anchor Listing

II. SEQUENCE OF EVENTS: What surrounding circumstances and sequence of events accompany the maltreatment (according to victims, siblings/other household members, nonoffending caretaker(s), perpetrator, and collateral sources)? Include environmental factors such as clean house, exposed wiring, etc.

\section{Narrative:}

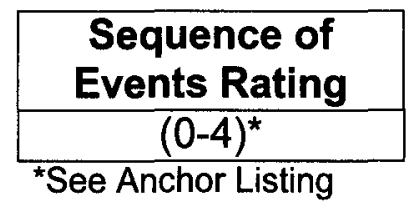

III. FAMILY DEVELOPMENTAL STAGES \& TASKS: What are the overall tasks the family typically face? How effective are their current parent practices? Include strengthens (i.e. ignores child's needs, has unrealistic expectations of child's functioning) and risks (i.e. ignores child's needs, has unrealistic expectations of child's functioning) any cultural or health issues which impact the developmental stage and tasks of the family. (A separate tab is provided for discussing discipline.)

\section{Selected Assessment Factors}

Chosen from listing of safety factors, i.e. Maltreating adult exhibits no remorse or guilt, Adults residing in home cannot explain injuries and/or conditions, Recent history of maltreatment escalation, etc. 
Narrative:

\begin{tabular}{|l|l|l|}
\hline Parent/Caretaker & CPS Rating & Comments \\
\hline & & \\
\hline
\end{tabular}

\begin{tabular}{|c|}
\hline $\begin{array}{c}\text { Family } \\
\text { Development } \\
\text { Rating }\end{array}$ \\
\hline$(0-4)^{\star}$ \\
\hline
\end{tabular}

*See Anchor Listing

IV. FAMILY CHOICE OF DISCIPLINE: What are the disciplinary approaches used by the parents/caretakers? Are certain developmental tasks high risk for reactive discipline? Include strengthens (i.e. uses self control while disciplining child, is fair and consistent, etc.) and risks (i.e. uses violence or threats, discipline is vengeful).

\section{Selected Assessment Factors}

Chosen from listing of safety factors, i.e. One or both adults intend(ed) to hurt child and do not show remorse, etc.

\section{Narrative:}

\begin{tabular}{|l|l|l|}
\hline Parent/Caretaker & CPS Rating & Comments \\
\hline & & \\
\hline
\end{tabular}

\begin{tabular}{|c|}
\hline $\begin{array}{l}\text { Family Choice of } \\
\text { Discipline Rating }\end{array}$ \\
\hline$(0-4)^{\star}$ \\
\hline
\end{tabular}

*See Anchor Listing

\section{INDIVIDUAL ADULT PATTERNS OF BEHAVIOR: Do certain adults have} individual self-control problems? What behavioral strengths do you notice? (i.e. is able to carry out the activities of daily living, makes plans for safety, etc.) What behavior do you see that may be high risk (i.e. high-risk behavior is escalating, employment problems, educational/vocational issues, exhibits little ability to handle life skills.)?

\section{Selected Assessment Factors}

Chosen from listing of safety factors, i.e. Previous reports in TWIST, There is a criminal record of assault/child molestation charges, alcohol/drug charges, or other relevant charges, There is a documented history, or observable indicators, of mental health problems, etc..

\section{Narrative:}




\begin{tabular}{|c|c|c|c|c|c|}
\hline $\begin{array}{c}\text { Parent/ } \\
\text { Caretaker }\end{array}$ & $\begin{array}{c}\text { CPS } \\
\text { Rating }\end{array}$ & $\begin{array}{c}\text { Criminal Records } \\
\text { Checked }\end{array}$ & CA/N & LINK & Comments \\
\hline & & & & & \\
\hline
\end{tabular}

\begin{tabular}{|c|}
\hline $\begin{array}{c}\text { Adult Patterns of } \\
\text { Behavior }\end{array}$ \\
\hline$(0-4)^{*}$ \\
\hline
\end{tabular}

${ }^{*}$ See Anchor Listing

VI. CHILD/YOUTH DEVELOPMENT: How do the children function on a daily basis? Are they able to accomplish developmentally appropriate tasks? Include strengths (i.e. developmentally on target, verbal, etc.) evasive behaviors, feelings, intellect, physical capacity, temperament, risks (i.e. intellectual functioning is age inappropriate), any cultural or health needs (include seizures) which impact child development, any educational/vocational issues, and any independent living skills needed. Address every child in home.

\section{Selected Assessment Factors}

Chosen from listing of safety factors, i.e. Any child is fearful of home situation, Any child shows effects of maltreatment such as serious physical, emotional, or behavioral symptoms, etc..

\section{Narrative:}

\begin{tabular}{|l|c|c|}
\hline Child/Youth & $\begin{array}{c}\text { CPS } \\
\text { Rating }\end{array}$ & Comments \\
\hline & & \\
\hline
\end{tabular}

\begin{tabular}{|c|}
\hline $\begin{array}{c}\text { Child } \\
\text { Development } \\
\text { Rating }\end{array}$ \\
\hline$(0-4)^{*}$ \\
\hline
\end{tabular}

*See Anchor Listing

VII. FAMILY SUPPORT: What is known about appropriate/positive family support systems? How do these support systems help the family protect the children?

\section{Selected Assessment Factors}

Chosen from listing of safety factors, i.e. Parents/caretakers do not have resources/support system to meet basic needs, etc.

Narrative: 


\begin{tabular}{|c|}
\hline $\begin{array}{c}\text { Family Support } \\
\text { Rating }\end{array}$ \\
\hline$(0-4)^{*}$ \\
\hline *See Anchor Listing
\end{tabular}

\section{RATINGS/FINDINGS/DECISIONS/ACTIONS}

\section{CPS RATINGS}

Maltreatment

Sequence of Events

Family Developmental Stages

Family Choice of Discipline

Adult Patterns of Behavior

Child Development

Family Support

\section{RISK ASSESSMENT}

High Risk (20 - 28)

Significant Risk (14-19.9)

Moderate Risk (7 - 13.9)

Low Risk $(0-6.9)$

TOTAL

ASSESSMENT/ONGOING CONCLUSION: Document the current status and action taken by the social services worker, adult caretaker, or others, in order to remove the risk. State justification, or rationale, for case closure or the continuation of ongoing services.

\section{Narrative:}

Worker Signature

Date

Supervisor Signature

Date 


\section{ANCHORS FOR CONTINUOUS QUALITY ASSESSMENT}

\section{Anchors-Child Maltreatment/Presenting Problem}

\section{CPS}

\section{Extreme - 4}

1. Throwing or shaking a child age $0-5$ (chronological or developmental)

2. Any injury to a non-mobile infant

3. Any inflicted injury to a child age 0-5 (chronological or developmental)

4. Any injury due to neglect to a child age $0-5$ (chronological or developmental)

5. Any previous child death due to unexplained or undetermined causes

6. Subsequent infant death where there is a history of SIDS

7. Restraints such as binding child or locking child in a closet, etc.

8. Inflicted burns

9. Injuries to head, face, genitals, internal injuries

10. Broken bone (injury inconsistent with explanation)

11. Punching or blows to the torso

12. Child injured or physically involved in a domestic violence incident

13. Weapons involved in abuse/neglect

14. Child exposed to sexual violence toward parent

15. Any child with a sexually transmitted disease

16. Any sexual abuse of a child

17. Sexual exploitation

18. Parent knowingly exposes child to a person in the home who presents danger to the child (i.e. domestic violence, sex offender, etc.)

19. Kidnapping/hostage taking

20. Unsupervised child 7 and under (chronological or developmental)

21. Abandonment

22. Life threatening unmet health needs

23. Failure to thrive/diagnosed malnutrition or dehydration due to neglect

24. Physician states child is at risk of abuse/neglect or has been abused/neglected

25. Qualified mental health professional has found emotional injury

26. Parent and/or child totally incapacitated due to drugs (including prescription drugs) or alcohol

27. Child has inappropriate access to drugs (including prescription drugs) or alcohol

28. Children without food for one day or more

29. Homeless-excluding shelters (living in car, barn, etc.)

30. Home with imminent risk factors (structurally unsound, exposed wiring, no heating source, rodent or insect infestation, raw sewage or garbage that presents a health hazard)

31. Refuses to cooperate with investigation or provide information

32. Child fatality due to abuse and/or neglect

33. Exposure to hazardous chemicals utilized in 'Meth Labs' or similar drug paraphernalia

34. Parent unwilling to allow child to come home due to refusal to deal with child's behavior, resulting in child needing placement

35. Any other situation deemed appropriate by FSOS that creates extreme risk to the child

\section{Status}

1. Suicidal ideations and/or homicidal ideations

2. Prostitution

3. Gang activity

4. Habitual runaway

5. Child's behavior is a danger to the family and due to this the parent is refusing to let the child come home

6. Child refusing to return home

7. Physical aggression towards parents/siblings/authority figures (medical treatment required)

8. Sexual perpetrating 
9. Use of any weapons

10. Drug (including prescription drugs) or alcohol addiction

11. Fire setting

12. Multiple placements due to child's behaviors

13. Child refuses to participate in mental health services

14. Beyond control (not following court orders)

15. Cruelty to animals

16. Total refusal to cooperate

17. Engages in criminal behavior

18. Any behavior that would require immediate placement

19. Any other situation deemed appropriate by FSOS that creates extreme risk to the child

$$
\text { Severe }-3
$$

\section{CPS}

1. Significant bruising to arms, legs, or buttocks

2. Prior unexplained injuries

3. Adult exposes self to child

4. Exposure to sexual activity or pornography

5. Parent/caretaker allows child to have inappropriate sexual relationships

6. Child witness to domestic violence (physical or threats)

7. Unmet health needs that result in future health problems or that may cause long term effects

8. Chronic use of drugs (including prescription drugs) or alcohol by parent while caring for child

9. Child forced to engage in criminal activity

10. Children exposed to the distribution of drugs(including prescription drugs) or criminal activity by the parents

11. Child under 14 allowed to engage in criminal activity including drug use

12. Children ages 8-10 unsupervised for extended periods of time (consider developmental age of child)

13. Children without food for less than one day

14. Physical altercation between parent/caretaker and child under age 12

15. Home smells of urine or feces or has trash or clutter creating fire hazard, broken screens or windows, exposed chemicals, medications or other hazards, etc.

16. Child under 16 not enrolled in school or home school program

17. Refuses to cooperate with investigation or provide information except by court order or police intervention

18. Parent/caretaker expresses fear they will harm child

19. Child expresses fear parent/caretaker will harm them

20. Any other situation deemed appropriate by FSOS that creates severe risk to the child

\section{Status}

1. Beyond control (not following house rules)

2. Physical aggression toward peers

3. Physical aggression toward parents/siblings/authority figures (no medical treatment needed)

4. Stealing from family and friends (no criminal charges filed)

5. Habitual truancy

6. Sexually active (under Age 16)

7. Experiments with drugs(including prescription drugs) or alcohol

8. Limited gang involvement

9. Refuses to cooperate without court intervention

10. Runaway, second occurrence

11. Destruction of property

12. Any other situation deemed appropriate by FSOS that creates severe risk to the child 


\section{Moderate - 2}

\section{CPS}

1. Bruising to the arms, legs or buttocks

2. Physical altercation between parent/caretaker and child 12 and over

3. Child age 8-10 unsupervised for short periods (consider developmental age of child)

4. Child age 12-15 unsupervised for extended periods (consider developmental age of child)

5. Failure to seek medical attention or lack of follow-up for ongoing, routine, non-life threatening conditions

6. Poor hygiene in children $0-7$ that has a negative impact on the child's health or emotional well-being

7. Child age 0-7 dressed inappropriately for weather conditions

8. Not enough food in the home to meet the basic needs of the family (chronic)

9. Home with no access to water, piled up clothing and papers, dirty dishes with mold and food, etc.

10. Qualified mental health professional has concerns about child's emotional well being

11. Recreational drug (including prescription drug) use by parent, but child has no access

12. Child ages 14 and older allowed to engage in criminal activity including drug use

13. Caretaker fails to make reasonable efforts to get child to school

14. Child left with family/caretaker with no provisions for making educational or medical decisions for child and no way to contact parent

15. Chronic pattern of parent/caretaker failing to follow through with recommendations to get rid of head lice

16. Any other situation deemed appropriate by FSOS that creates moderate risk to the child

\section{Status}

1. Past CPS issues

2. Anger control issues

3. Verbal aggression

4. Escalating negative behavior

5. Teen pregnancy (over age 16)

6. Sexually active (over age 16 )

7. Escalating court involvement

8. Physical intimidation

9. Runaway, first occurrence

10. Truancy (children over 12)

11. Police intervention

12. Limited cooperation

13. Any other situation deemed appropriate by FSOS that creates moderate risk to the child

\section{Mild - 1}

\section{CPS}

1. Minor bruising to older children

2. Poor hygiene for children over 7 that has a negative impact on the child's health or emotional well-being

3. Worker or community partner has concerns about emotional well being

4. History of drug (including prescription drug) or alcohol abuse

5. Home with inadequate heat, food, home cluttered, dirty dishes, etc

6. Parent has failed to follow through with getting rid of head lice

7. Any other situation deemed appropriate by FSOS that creates mild risk to the child 


\section{Status}

1. Leaving home without permission

2. Mutual altercation between peers (no injuries)

3. Physical altercation (pushing and shoving only, no police involvement)

4. Cooperates at least minimally

5. Excessive absences or tardiness

6. Difficulty with authority issues

7. Mental health issues (treated)

8. Anger management issues (treated)

9. Any other situation deemed appropriate by FSOS that creates mild risk to the child

$$
\text { None - } 0
$$

\section{CPS}

1. No prior CPS, APS referrals or FINSA's

2. No maltreatment found

3. Child is dependent through no fault of the parent/caretaker

4. General family services (no risk factors present)

\section{Status}

1. Cooperation with service providers

2. Following supervision/probation conditions

3. Following through on case plan objectives

4.

\section{Anchors For Child-Sequence Of Events}

\section{Extreme - 4}

\section{Investigation}

1. History of diagnosed mental illness or observable bizarre behavior which presents a risk to the child(ren)

2. Maltreatment is justified by parents as a cultural or religious practice

3. Long term abuse or neglect has occurred with detrimental results

4. Circumstances surrounding maltreatment are unclear and no definite cause can be found

5. Pattern of behavior escalation over time

6. Use of weapons or objects

7. Domestic violence with physical harm to child or adult

8. Child is continuously exposed to ongoing domestic violence

9. Total incapacitation due to drug(including prescription drug) or alcohol abuse, which results in a parent's inability to care for the child(ren)

10. Adult is unable to verbalize high-risk times/triggers

11. Adult refuses to be interviewed or could not be located

12. Any other situation deemed appropriate by FSOS that creates extreme risk to the child

\section{Ongoing}

1. Mental health professional has indicated that parent/caretaker is not capable of providing care for child or presents a danger to the child's safety

2. Continually refuses to address issues that led to maltreatment and that are documented on the case plan or avoids making contact with the worker

3. Refuses to or has not participated in any parenting classes, counseling sessions, substance abuse treatment, Alcoholics Anonymous, Narcotics Anonymous, or domestic violence offender treatment that is part of the case plan or court ordered

4. Received a new drug(including prescription drugs) or alcohol-related charge, or a new act of domestic violence occurred since last assessment 
5. There has been a substantiated finding of child/adult abuse or neglect since the last assessment

6. Has repeatedly failed to get child to counseling

7. Was asked to leave in-patient drug (including prescription drugs) or alcohol abuse program, or left on their own before treatment was completed

8. Continues to blame agency, school, community partner, other household member or child for problems

9. Continuously appears unable to comprehend seriousness of the issues that caused their case to be opened

10. Refuses to allow worker to visit home at scheduled times, or repeatedly fails to show for DCBS office visits

11. Refuses random drug/alcohol screens

12. Has a positive drug/alcohol screen, or results show a diluted specimen

13. Has not kept scheduled visits with the child

14. Had to be asked to leave visit due to inappropriate behavior

15. Visits are supervised due to concerns about child's safety

16. Parent's whereabouts are unknown

17. Any other situation deemed appropriate by FSOS that continues to place child at risk

\section{Severe - 3}

\section{Investigation}

1. Adult's explanation of maltreatment is not consistent with information obtained

2. Adult denies, minimizes or blames others for maltreatment (perpetrator)

3. Drug(including prescription drugs) or alcohol abuse resulting in a substantial incapacity on the part of the parent

4. History of intergenerational abuse/neglect

5. Multiple victims

6. Uses threats of harm

7. Use of power and control is the primary method of getting ones way

8. History of intergenerational domestic violence

9. History of protective orders or criminal charges

10. Parent/caretaker is only minimally able to verbalize high-risk times/triggers

11. Any other situation deemed appropriate by FSOS that creates severe risk to the child

13. Non-offending parent does not believe that maltreatment occurred

\section{Ongoing}

1. There has been a new FINSA since the last CQA and service needs were identified

2. Has attended a minimum of parenting classes, but teacher documents that he/she does not participate, they fail to demonstrate techniques learned or claim he/she already knows everything the instructor taught

3. Regularly attends counseling sessions, but is not willing to address issues in their past which contribute to their inability to provide adequate care for their child

4. Non-offending parent continues to believe that maltreatment did not occur

5. Has discontinued domestic violence/sex offender treatment

6. Fails to follow through with the aftercare plan for treatment after completing an in-patient program.

7. Fails to maintain safe, stable housing or source of income

8. Missed $50 \%$ or more of their visits with child without calling to cancel or reschedule

9. Interaction with child during visits is inappropriate, (i.e., when child is out of control parent fails to intervene, or worker has to demonstrate to parent/caretaker how to interact with/or care for child, etc.)

10. Continues to deny that drug (including prescription drugs) or alcohol dependency is an issue for them, stating they only drink socially

11. Appears to have no understanding of why drug (including prescription drugs) or alcohol dependency may impair their ability to care for their child 
12. Has no understanding of how domestic violence may impair their ability to care for their child

13. Allows child to attend counseling, but child has missed $50 \%$ or more of their sessions

14. Is more interested in arguing with worker than in dealing with issues that create risk to the child

15. Is often not home for scheduled home visits by worker

16. Acknowledges a drug (including prescription drugs) or alcohol dependency, but believes usage can be controlled without treatment

17. Is always home for scheduled visits, but is unwilling to talk with worker about case plan

18. Any other situation deemed appropriate by FSOS that continues to place child at risk

\section{Moderate - 2}

\section{Investigation}

1. Adult/parent's behavior has occurred over time without injury to the child

2. Drug (including prescription drug) or alcohol abuse that results in problem behavior (legal problems or job loss)

3. Adult can verbalize high-risk times/triggers but responds inconsistently

4. Positive methods of dealing with family problems are rarely used

5. Any other situation deemed appropriate by FSOS that creates moderate risk to the child

\section{Ongoing}

1. States they can fix the problems without interference from worker and/or other community partners

2. Worker has to demonstrate how to interact with child, but parent appears to be increasing in skill level

3. Child's return will create additional stress for the family

4. Any other situation deemed appropriate by FSOS that continues to place child at risk

\section{Mild - 1}

\section{Investigation}

1. First time occurrence and/or parent expresses remorse.

2. Parent currently experiencing situational stress.

3. Some success with use of problem-solving techniques.

4. Adult is usually able to verbalize high-risk times/triggers and usually responds appropriately.

5. Any other situation deemed appropriate by FSOS that creates mild risk to the child.

\section{Ongoing}

1. Attends most counseling/parenting sessions and can demonstrate an understanding of issues and skills that will enable them to prevent further abuse

2. States they understand the dangers of drug (including prescription drugs) or alcohol dependency for both them and their children.

3. Attends some form of alcohol/drug support group fairly regularly and can state to worker how their participation has helped them to understand the dynamics of drug(including prescription drug) or alcohol dependency

4. Any other situation deemed appropriate by FSOS that continues to place child at risk

$$
\text { None - } 0
$$

\section{Investigation}

1. Facts are consistent with parent's explanation of circumstances

2. No threats or use of violence to resolve conflict

3. No history of intergenerational violence

4. No past or present drug (including prescription drug) or alcohol abuse

5. Adult verbalizes high-risk times/triggers and demonstrates appropriate responses 


\section{Ongoing}

1. Has completed drug/alcohol treatment, attends some type of drug/alcohol support group, and understands the dangers of drug (including prescription drug) or alcohol use on them and their children

2. Makes sure child attends counseling sessions and will participate with child when requested

3. Has completed all aspects of the case plan, and can demonstrate to the DCBS worker and/or other community partners skills they have learned to decrease risk

4. Has demonstrated appropriate methods of non-physical discipline

\section{Anchors-Family Stages-Development and Tasks}

\section{Extreme - 4}

1. Exhibits behavior based only on parent/caretaker's needs

2. Non-offending parent puts needs of the perpetrator before the needs of family (fails to protect)

3. Ignores child's strengths/limitations/needs

4. Demonstrates expectations impossible for child to meet

5. Does not provide basic care, nurturing, and/or support

6. Places child in unsafe situations

7. Previous termination of parental rights

8. Culture (beliefs, traditions, values) places child/family at imminent risk

9. Chronically transient

10. No known source of income

$$
\text { Severe }-3
$$

1. Does not exhibit behavior taking into account child's chronological/developmental age

2. Insensitive to child's strengths/limitations/needs

3. Usually does not provide basic care, nurturing, and/or support

4. Impulsive in most areas of parenting/caretaking

5. History of confirmed severe/chronic abuse and/or neglect (no current maltreatment)

6. History of child placement

7. Dissatisfied with parent/caretaker role

8. Divorced/separated parents place child(ren) in middle of conflict

9. Teen pregnancy(under age 16)

10. K-TAP is only source of income (time limited)

\section{Moderate - 2}

1. Usually does not exhibit behavior considering the child's chronological/developmental age

2. Sometimes has unrealistic expectations based on the child's strengths/limitations/needs

3. Inconsistent in providing basic care, nurturing and/or support

4. Exhibits limited self-control in most areas of parenting/caretaking

5. Confirmed history of abuse and/or neglect

6. Somewhat dissatisfied with parent/caretaker role

7. Inconsistent employment

\section{Mild - 1}

1. Sometimes fails to exhibit behavior considering the child's chronological/developmental age

2. Inconsistent expectations based on the child's strengths/limitations/needs 
3. Sometimes inconsistent in providing basic care, nurturing, and/or support

4. Does not exhibit self control in certain areas of parenting/caretaking

5. Somewhat satisfied with parent/caretaker role

6.

$$
\text { None - } 0
$$

1. Exhibits behavior taking into account child's chronological/developmental age

2. Possesses reasonable expectations for the child based on strengths/limitations/needs

3. Provides basic care, nurturing and support

4. Is protective

5. Demonstrates positive parent/caretaker skills

6. Satisfied with parent/caretaker role

\section{Anchors-Choice Of Discipline}

\section{Extreme - 4}

1. Method of discipline results in injury to the child

2. Discipline includes violence, threats and verbal assault

3. Adult uses disciplinary methods that are unrealistic for the child

4. Adult consistently takes frustrations out on child

5. Discipline is applied excessively and without consideration to the child's chronological age or developmental age

6. Punishment is seen as the primary function of parenting

7. Adult is unaware of appropriate methods of discipline

\section{Severe - 3}

1. Uses negative/inappropriate disciplinary approaches

2. Discipline sometimes occurs as the adult's reaction to frustration or anger

3. Generally limited in the discipline methods used

4. Parent encourages child to defy authority or engage in other negatives behaviors

5. Discipline applied inconsistently without consideration to the child's chronological age or developmental age

6. Does not attempt to control child's behavior or a lack of discipline in the home (could include curfew)

7. Allows or expects a child or another adult to discipline

\section{Moderate - 2}

1. Occasionally loses self-control when disciplining, without injury occurring

2. Inappropriate discipline may occur but is out of character from typical approach

3. May know different disciplinary approaches, but does not demonstrate willingness or capacity to apply them

\section{Mild - 1}

1. Inconsistent use of discipline

2. Some indication of varied disciplinary methods

3. Seldom loses control when disciplining child

$$
\text { None - } 0
$$

1. Attempts to balance teaching and punishing 
2. Matches discipline appropriately with child's needs, age, behavior and acts

\section{Anchors-Adult Patterns of Behavior}

\section{Extreme - 4}

1. Has current violent behavior that results in injury to child requiring medical treatment

2. Has current violent behaviors that are occurring more frequently or are escalating in severity

3. Has untreated mental illness or indicators of mental illness resulting in high risk behavior or incapacity

4. Has a documented history and current indicators of drug (including prescription drug) or alcohol abuse

5. Has a history of substantiated child sexual abuse

6. Has a history of substantiated physical abuse or neglect of a child 0-5

7. Has abused animals

8. Has a physical or mental impairment that makes them incapable of meeting the child's needs

9. Blames child for own problems and does not take responsibility for own actions

10. Will not or can not protect self or child from harm

11. Has isolated self or others in the home from any outside supports

12. Refuses to cooperate with the investigation

13. Action or lack of action contributed to the death of a child

14. Criminal record shows pattern of drug (including prescription drug) or alcohol use or violence

15. Currently involved in a relationship with a person who has high risk behaviors (i.e. domestic violence, sex offender, etc.)

\section{Severe - 3}

1. Has a documented history of violent behavior or current indicators of violent behavior

2. Has a mental illness and is in treatment but still has some high-risk behavior

3. Has documented history or current indicators of drug (including prescription drug) or alcohol abuse

4. Has a history of substantiated physical abuse or neglect on a child 6 and over

5. Has a physical or mental impairment that limits their ability to meet child's needs

6. Has isolated self or others in the home from most outside support

7. Serial relationships with partners who have high-risk behaviors

8. Has chronic financial problems that prevent them from meeting vital needs of child

9. Cooperates with part of the investigation but refuses to provide some information

10. Exhibits little ability to manage life skills

11. Uses poor judgment in choosing appropriate caretakers

12. Adult is unable to read or write, affecting their ability to care for the child

\section{Moderate - 2}

1. Has documented history of drug (including prescription drug) or alcohol abuse, but no indication of current use

2. Two or more unsubstantiated reports of abuse or neglect

3. Has a physical or mental impairment that limits ability to meet child's need but accepts assistance

4. Has isolated self or others in the home from some outside support

5. Has occasional financial problems that prevent them from meeting some of child's needs

6. Has unrealistic expectations of the child

7. Has a history of mental health treatment with no current indicators of illness

8. Parent's work schedule interferes with supervision of the child 
1. Has a history of drug (including prescription drug) or alcohol treatment with no current indicators of abuse

2. Has a prior unsubstantiated report of abuse or neglect

3. Has a physical or mental impairment that does not appear to limit ability to meet child's needs

4. Is struggling, but able to meet financial needs of family

$$
\text { None - } 0
$$

1. There is no indication that parent/caretaker has been violent with others, abused drugs(including prescription drugs) or alcohol, or has any mental illness

2. There are no prior or current reports of child abuse or neglect

3. Appears to be willing and able to meet all needs of the child

4. Demonstrates the ability to cope with daily life events and stressors

5. Has an appropriate social support system

\section{Anchors-Child Development}

\section{Extreme - 4}

1. Any child age $0-3$ or any child who is older and non-verbal

2. Child unable to bond with anyone

3. Infants or toddlers who cry excessively or have "colic"

4. Medical condition that incapacitates child and requires a caretaker to learn about and provide care

5. Life threatening illness or injury

6. Has seizures that are frequent or severe

7. Has a mental illness that requires in-patient treatment or is a threat to self or others

8. Has behaviors symptomatic of current or past abuse/neglect (including exposure to domestic violence or substance abuse)that is impairing their ability to function at school, in the home or socially and is currently not in counseling.

9. Condition or behavior requires an Individual Education Plan (IEP), but it is not working

10. Sexualized behavior by a child that causes injury to self or others

11. Any child who has multiple sex partners or child who prostitutes

12. Child is approaching adulthood and is unable to function outside of a residential facility

13. Committed to CFC as a status offender and placed out of the home

14. Child has drug(including prescription drug) or alcohol addiction

15. Child refuses to attend school or is failing all subjects

$$
\text { Severe - } 3
$$

1. Any child age 4-6 or any child with limited cognitive or verbal skills

2. Unable to bond with caretaker, but has sufficient bond with others

3. Has a medical condition that limits child and requires some specialized knowledge or care

4. Has a mental illness that requires intensive treatment or behaviors are out of control

5. Child is in counseling due to current or past abuse/neglect (including exposure to domestic violence or substance abuse)and the child's behaviors continue to present problems with their ability to function at school, in the home or socially.

6. Is in need of an Individual Education Plan (IEP) but one has not been developed

7. Public displays of sexualized behavior to self or others

8. Explicit knowledge of sexual acts or sexual statements that are advanced for age 
9. Is delayed for chronological age in reaching a developmental milestone (walking, toilet training, etc.)

10. Inconsistent school attendance or failing some subjects

11. Chronic use of drugs (including prescription drugs) or alcohol

12. Is approaching adulthood and is unable to function without supervision or community support

13. Status offender committed to the Cabinet, but remains in the home

\section{Moderate - 2}

1. Medical condition that somewhat limits child and may require regular medical follow-up

2. Exhibits behaviors that are interfering with normal functioning at home or school

3. Has mental illness that is currently controlled by medication and therapy

4. Child has been abused/neglected in the past or has been exposed to domestic violence or substance abuse and has no observable behaviors that are problematic.

5. Requires an Individual Education Plan (IEP) which is mostly successful

6. Older child having unprotected sex with a peer

7. Experimenting with drugs(including prescription drugs) or alcohol

8. Currently experiencing an unusual life stressor and is not coping well

9. Status offender who is probated to CFC

\section{Mild - 1}

1. Occasionally suffers from a medical condition that requires care

2. Has a mental illness currently controlled by therapy or behavior management

3. Struggles in some subjects in school

4. Currently experiencing an unusual life stressor but is coping well

5. Status offender under limited supervision of CFC; monitors community service work

$$
\text { None - } 0
$$

1. Has no medical or mental health problems

2. Functions well at school with peers and in academic areas

3. Does not exhibit behavior problems at home or school

4. Is not currently experiencing any unusual life stressors

\section{Anchors-Formal and Informal Support System}

\section{Extreme - 4}

1. Unable to access any community resources or supports

2. Family refuses to provide any information about extended family members or other support systems

3. Unwilling to ask for help when needed

4. Has no extended family

5. Has no contact with extended family (could be geographic)

6. Family/friends encourage the adult/family to remain in a harmful situation

7. Family/friends discourage adult from seeking assistance

8. Family is totally isolated (geographically or emotionally)

9. Family/friends reinforce or promote unacceptable behavior

10. No community support

11. Extended family does not believe the parent(s) is responsible for maltreatment 


\section{Severe - 3}

1. Has family members/friends but assistance is inappropriate and unhelpful

2. Family is unable to access any community resources or supports

3. Existing community supports are inadequate or withdrawn for some reason

4. Peers are a negative influence

5. Extended family refuses to assist the family in meeting needs (i.e. child care, transportation, etc.)

6. Adult or child lacks a significant, stable adult relationship

7. Friends/extended family are interfering, uncaring or unsupportive

8. Family has no formal support from clubs, churches or organizations

9. Family has no friends/support system

10. Family/friends not supportive of adult making decisions

\section{Moderate - 2}

1. Family has contact with, but refuses assistance from, extended family or friends

2. Community resources not accessible (waiting lists)

3. Extended family/friends threaten to withdraw support or assistance

4. Out of home care provider requires assistance in meeting child's needs.

$$
\text { Mild - } 1
$$

1. Some involvement with community resources

2. Limited support from clubs, churches, organizations, friends or extended family

3. Family has some understanding of the need to seek assistance from others.

$$
\text { None - } 0
$$

1. Contacts community resources when needed

2. Extended family/friends willing to support and assist

3. Family supported by clubs, organizations or churches

4. Out of home provider and birth family are working to meet the needs of the child

(Cabinet for Families and Children, 2003) 


\section{Appendix B}

\section{Council on Accreditation Standards}

The following COA standards have applicability to this study:

\section{G2 Continuous Quality Improvement}

G2.5 The organization evaluates its systems and procedures and uses its findings to improve its performance.

G.2. 6.01 At least quarterly, each of the organization's services reviews a sample of open and closed cases that includes a representative sample of high-risk cases.

G.2.6.02 Personnel who conduct case record reviews evaluate the presence or absence of required documents, and the clarity and continuity of such documents, which include, but are not limited to: assessments, service plans, appropriate consents, progress or case notes or summaries, evidence of quarterly case supervision, relevant signatures, and service outcomes. G.2.7.01 The organization, in each of its programs and on an ongoing basis, measures service outcomes and the achievement of service goals for all persons serviced.

G. 2.7 The organization has an outcome measurement system in each of its programs, which evaluates individual progress and program effectiveness G. 2.7.2 The organization aggregates and analyzes outcomes data for persons served for each of its programs to determine program effectiveness G.10 The organization maintains information that is necessary to plan, mange, and evaluate its services. 


\section{S5 Case Management Services}

S5.2 The organization conducts an assessment of each case as the basis for service planning and delivery

S.5.3 Service planning and coordination are comprehensive and based upon the findings of the assessment

\section{G8 Assessment and Case Planning}

G8.2.02 Assessments are tailored to individual need and service objectives and the organization collects only such information as is necessary to provide the requested services.

G8.4 The organization develops a written service plan in a timely manner for each person, family, or group that is based on the findings of the assessment and involves, to the fullest extent possible, the participation of the person, family, or group served.

G8.5.02 As appropriate, and with the consent of the person's served...the organization develops a family-centered service plan that identifies strengths, plans for maintaining or strengthening the relationship between the person served and his/her family

\section{G9 Service Delivery}

G9.6 The organization routinely monitors its cases to evaluate service plan implementation and the appropriateness of services.

G9. 7.01 The organization ensures that termination of service, whether voluntary or involuntary, is an orderly process. 
G9.7.02 Termination or discharge occurs when the person or family achieves their goal or is otherwise ready to discontinue services

\section{S10 Child Protective Services}

S10.3.04 The organization uses standardized assessment and planning criteria for decision-making that explores and includes: child safety, family connections, family strengths, and permanency planning

S10.5.02 The organization provides intensive services and more frequent monitoring when the responsible parents demonstrate behavior that substantially inhibits the parents' or caretakers' ability to care for the child; and the service plan addresses a longer period in which services to the family may be required for a successful problem resolution. (Council on Accreditation, 2001) 


\section{Appendix C}

\section{Kentucky Revised Statues Defining Abuse/Neglect}

\section{KRS $600.020(1)$}

Abused or neglected child means a child whose health or welfare is harmed or threatened with harm when his parent, guardian, or other person exercising custodial control or supervision of the child:

(a) Inflicts or allows to be inflicted upon the child physical injury by other than accidental means;

(b) Creates or allows to be created a risk of physical or emotional injury to the child by other than accidental means;

(c) Engages in a pattern of conduct that renders the parent incapable of caring for the immediate and ongoing needs of the child including, but not limited to, parental incapacity due to alcohol and other drug abuse;

(d) Continuously or repeatedly fails or refuses to provide essential parental care and protection for he child, considering the age of the child;

(e) Commits or allows to be committed an act of sexual abuse, sexual exploitation, or prostitution will be committed upon a child;

(f) Commits or allows to be created a risk that an act of sexual abuse, sexual exploitation, or prostitution will be committed upon a child; 
(g) Abandons or exploits the child; or

(h) Does not provide the child with adequate care, supervision, food, clothing, shelter, and education or medical care necessary for the child's well-being. A parent or other person exercising custodial control or supervision of the child legitimately practicing the person's religions beliefs shall not be considered a negligent parent solely because of failure to provided specified medical treatment for a child for that reason alone. This exception shall not preclude a court from ordering necessary medical services for a child, or

(i) Fails to make sufficient progress toward identified goals set forth in the court-approved case plan to allow the safe return of the child to the parent that results in the child remaining committed to the cabinet and remaining in foster care for fifteen (15) of the most recent twenty-two (22) months.

\section{KRS $600.020(8)$}

Child means any person who has not reached his eighteenth birthday

\section{KRS 600.020(19)}

Dependent child means any child, other than abused or neglected child, who is under improper care, custody, control, or guardianship that is not due to an intentional act of the parent, guardian, or person exercising custodial control or supervision of the child. 
KRS 600.020(24)

Emotional injury means an injury to the mental or psychological capacity or emotional stability of a child as evidence by a substantial and observable impairment in the child's ability to function within a normal range of performance and behavior with due regard to this age, development, culture, and environment as testified to by a qualified mental health professional.

\section{KRS 600.020(42)}

Person exercising custodial control or supervision means a person or agency that has assumed the role and responsibility of a parent or guardian for the child, but does not necessarily have legal custody of the child.

\section{KRS 600.020(44)}

Physical injury means substantial physical pain or any impairment of physical condition.

\section{KRS 600.020(55)}

Sexual abuse includes, but is not necessarily limited to, any contacts or interactions in which the parent, guardian, or other person having custodial control or supervision of the child or responsibility for his welfare, uses or allows, permits, or encourages the use of the child for the purposes of sexual stimulation of the perpetrator or another person. (Kentucky Legislative Research Commission, 2003) 


\section{Appendix D}

\section{Risk Assessment Research Chart Review Form}

\section{Case Status}

1. ID \#

2. Region Code (state listing)

3. County Code (state listing)

4. Primary Program of Service
1. Placement
2. Neglect
3. Physical Abuse
4. Community Based
5. Dependency
6. Sexual Abuse
7. Emotional Abuse
8. General Family
9. Other

5. Number of Referrals in Case At Time of Case Closure

6. Number of Substantiated Referrals in Case At Time of Case Closure

7. Number of Active Individuals in Case

8. Months Case Open for Current Treatment Episode

9. Months Case Open for Previous Treatment Episode

\section{Case Service Elements}

10. Targeted Case Mangement Contacts (TCM) in Case During Month Prior to Case Closure

11. TCM Contacts in Case During 2 Months Prior to Case Closure (number)

12. TCM Contacts in Case During 3 Months Prior to Case Closure (number)

13. Date of Last Face to Face Contact Prior to Case Closure (number)

14. Date of Last Ongoing CQA Prior to Case Closure 
15. Date of Last Case Plan Prior to Case Closure

16. Case Plan Current at Time of Case Closure

1. Yes

2. No

17. For Cases With Prior Service Episode, Date Last Closed

18. For Cases With Prior Service Episode, Date Originally Opened

19. Council on Accreditation Case
1. Yes
2. No

\section{Client Status}

20. Most Recent Date case opened (Current Treatment Episode)

21. Date of First CQA (Current Treatment Episode)

22. Scores on First CQA
1. Cumulative Rating
2. Maltreatment
3. Sequence of events
4. Family Development Stages
5. Family Choices of Discipline
6. Adult Patterns of Behavior
7. Child/Youth Development
8. Family Support

23. Date Case Closed (Current Treatment Episode)

24. Date of Last CQA (Current Treatment Episode)

25. Scores on Last CQA
1. Cumulative Rating
2. Maltreatment
3. Sequence of events
4. Family development stages
5. Family Choices of Discipline
6. Adult Patterns of Behavior
7. Child/Youth Development
8. Family Support

26. Date of Last Quality Risk Assessment 
27. Change In Risk Rating Between Opening and Closing CQA

28. Change in Sequence of Events Between Opening and Closing CQA

\section{Recidivism on Targeted Cases}

29. New Incidents of Maltreatment Since Closure

1. Yes

2. No

30. Number of Children Involved in Referrals Following Case Closure

31. Substantiated Incidents of Maltreatment Following Case Closure

32. Unsubstantiated Incidents of Maltreatment Following Case Closure

33. Date of first referral following case closure

34. Gender of child 1 in new incidents of maltreatment

35. Age of child 1 in new incidents of maltreatment

36. Gender of child 2 in new incidents of maltreatment

37. Age of child 2 in new incidents of maltreatment

38. Gender of child 3 in new incidents of maltreatment

39. Age of child 3 in new incidents of maltreatment

40. Gender of child 4 in new incidents of maltreatment

41. Age of child 4 in new incidents of maltreatment

42. Gender of child 5 in new incidents of maltreatment

43. Age of child 5 in new incidents of maltreatment

44. Gender of child 6 in new incidents of maltreatment

45. Age of child 6 in new incidents of maltreatment

46. Gender of child 7 in new incidents of maltreatment

47. Age of child 7 in new incidents of maltreatment 
48. Supervisor ID \#

49. Supervisor Degree
1. Bachelor
2. Masters

50. Supervisor Area of Study
1. Social Work
2. Sociology
3. Psychology
4. Family Studies
5. Corrections
6. Other
7. Human Studies
8. Counseling
9. Unspecified, not Social Work

51. Supervisor Gender
1. Male
2. Female

52. Supervisor Years of Service

53. Case Manager ID \#

54. Case Manager Position
1. Worker
2. Clinician
3. Specialist
4. Supervisor

55. Case Manager Area of Study
1. Social Work
2. Sociology
3. Psychology
4. Family Studies
5. Corrections
6. Other
7. Human Studies
8. Counseling
9. Unspecified, not Social Work 
56. Case Manager Gender

1. Male

2. Female

57. Case Manager Years of Service

58. Case Manager Degree

1. Bachelor

2. Masters 
Appendix E

Letter of Approval

Institutional Review Board For The Protection of Human Subjects

Kentucky Cabinet For Families and Children 


\section{PALLE. PATTON GOVER.VOR}

April 15.2002

\section{THE SECRETARY FOR FAMILIES A.VD CHILDREY COMMONWEALTH OF KENTUCKY \\ 275 EAST MAIN STREET \\ FRA.IKFORT $+6621-0 \mathrm{COO}$ \\ (502) $56+-7130$ \\ (502) $564-3866$ FAX}

VIOLA P. MILLER, ED. D.

SECRETARY

Helen Mudd

Lincoln Trail Protection and Permanency

Department for Community Based Services

901 Aktinson Hill Avenue

Bardstown. KY 40004

Dear Mss. Mludd:

Based upon the information that you have submitted, the Institutional Review Board staff, in accordance with 920 KAR 1:060 Section 2(3)(d), has determined that both Phase I and Phase II of your researeh project entitied "Risk Assessment as a Measure of Effectiveness of Child Protective Services in Public Child Welfare Agency" is exempt from review by the IRB pursuant to 45 CFR 46.101(b)(4) and $46.101(b)(5)$. Therefore, with the approval and cooperation of the appropriate staff in the Department for Community Based Services, you may initiate the research activities as you have described in your research request.

In addition to all other requirements of 45 CFR 46.101-46.409, 920 KAR 1:060, and the Cabinet for Families and Children's "Protocol and Procedures for the Use of Hunan Subjeses in Research," it is the responsibility of the researcher to:

(1) obtain approval by the Board for any modification in the research protocol or design that may increase the level of risk to a subject or a subject's conficentiality prior to implementation. Failure to obtain prior approval of the Board shall result in the suspension or termination of the initial board approval and the requirement that all research accivity be stopped; .

(2) advise the $I R B$ of any unanticipated problem involving a risk to a subject or another individual as a result the research activity as soon is possible;

(3) prepare an annual report and submit to the $\mathbb{R B}$ an annual request for continuing approval of an ongoing research study:

(4) submit to the IRB a copy of the final research findings and conclusions.

If you have any questions or need additional information, please contact Bob Blackburn, $\mathbb{R} B$ Administrator (502) 564-2767 $\times 4$ 102). Otherwise, you may proceed with the study as agreed.

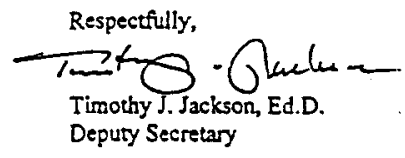

cc: Institutional Review Board Members

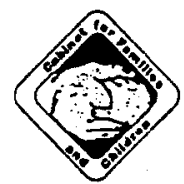

An Eqqual Opporturity Employer - NUE/D

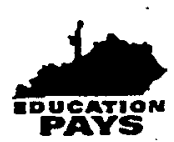




\begin{abstract}
Appendix F
Letter of Approval

Institutional Review Board For The Protection of Human Subjects

University of Louisville
\end{abstract}




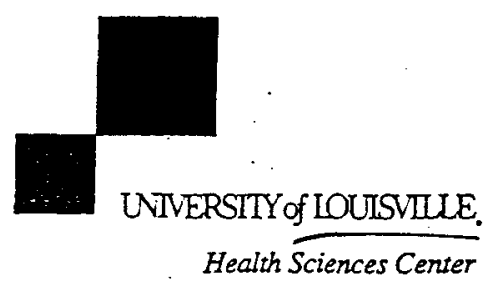

October 21, 2002

Dr. Thomas Lawson

Kent School of Social Work

RE: 556-02 Risk Assessment As a Measure of Effectiveness of Child Protective Services in a Public Child Welfare Agency

\section{Dear Dr. Lawson:}

The above-referenced study has been received by the Human Studies Committees. It has bee determined that the study is exempt according to 45 CFR 46.101 (b) 2.

Thank you for keeping us informed as to your research activity.

Sincerely,

Edurad Rlint

Edward R. Leist, PharmD

Interim Chair, Human Studies Committees

ERL/rsh

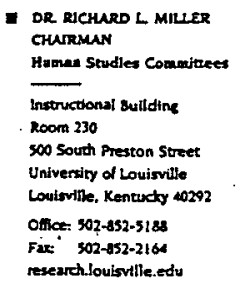




\section{CURRICULUM VITAE}

\section{Helen Mudd, Ph.D., MSSW, MS}

Work: 502-348-3552 (FAX 502-349-6450)

Home: 502-348-3552

Hmudd@bardstown.com

\section{POSITION}

Since August, 2001

Regional Treatment Specialist

Cabinet for Families and Children

State of Kentucky

Since January 1997

Field Educational Liaison

Kent School of Social Work

University of Louisville

January, 1999 to January, 2002

Adjunct Faculty

Carver School of Social Work

Campbellsville University

Campbellsville, Kentucky

November, 1990 to July 2001

Family Services Office Supervisor

Cabinet for Families and Children

State of Kentucky

November, 1989 to November, 1990

District Services Coordinator

Cabinet for Families and Children

Contracted through Eastern Kentucky University

May, 1985 to November 1989

Family Services Worker, Senior

Cabinet for Families and Children

State of Kentucky

May, 1983 to May 1985

Receiving and Discharge Officer

Corrections Cabinet

State of Kentucky 
Ph.D, May, 2004

University of Louisville

Kent School of Social Work

Dissertation: Child Maltreatment Assessment and

Recidivism: A Study of Kentucky Child Protective Services

MSSW, 1990

Kent School of Social Work

University of Louisville

Phi Kappa Phi

GPA: 4.0

MS, 1979

Eastern Kentucky University

Criminal Justice Education

GPA: 3.9

BSW with Distinction, 1976

Eastern Kentucky University

TEACHING

INTERESTS

TEACHING

EXPERIENCE

Practice

Child Welfare

Field

Research

Kent's Master of Science in Social Work (MSSW)

University of Louisville

Educational Field Liaison (current)

\section{Campbellsville University}

Carver School of Social Work

Campbellsville, Kentucky

Introduction to Research (Undergraduate)

Macro Practice (Undergraduate)

RESEARCH Dissertation: Child Maltreatment Assessment and

Recidivism: A Study of Kentucky Child Protective Services

$1999-2001$

\section{Students' Evaluation of Field Placements}

This study analyzed student responses on field placement surveys at the Kent School of Social Work. Content analysis was used to identify major strengths and limitations of the field placement program. 
This pilot project provided workers with a measurement tool to evaluate casework effectiveness in protective service cases. Practitioners utilizing a single subject design evaluated their casework effectiveness in 102 protective service cases over a two-year period.

NATIONAL PRESENTATIONS

INVITED PRESENTATIONS

\section{January 29-31, 2000 (Poster Presentation)}

Practitioners Evaluate Effectiveness by Measuring Relapse Prevention Skills

Society For Social Work and Research in Charleston, South Carolina

\section{March 10-13, 1999 (Paper Presentation)}

Practitioners Evaluate Effectiveness by Measuring

Relapse Prevention Skills

Council on Social Work Education's APA in San

Francisco, California

December 3, 2003

Presented Continuous Quality Assessment to Central Office Staff, Cabinet for Families and Children

October 30, 2003

Presented Lincoln Trail Regional progress report on achievement of ASFA outcomes to Central Office Staff, Regional Staff from selected regions, and invited community participants.

July 21, 2003

Presented Outcomes of Kentucky's 2003 Children and Family Services Review to Communicare Management Staff

June 20, 2003

Presented Outcomes of Kentucky's 2003 Children and Family Services Review to Lincoln Trail VISION (Taped and broadcast on local television on 2 additional occasions)

June 2, 2002

Presented case assessment and planning process to Council on Accreditation Site Visitors, Regional and Central Office Staff 
December 4, 1998

Presented casework effectiveness pilot project to University of Louisville/University of Kentucky Ph.D. students

HONORS AWARDS

2003

Approved by Children's Bureau, U.S. Department of Health and Human Services, as federal consultant for Children and Family Services Reviews

\section{3}

Selection as State Reviewer for Children and Family Service Review

Cabinet for Families and Children

\section{2}

Commendation for Hard Work and Dedication to COA (Council on Accreditation) Process

Lincoln Trail Cabinet for Families and Children

\section{0}

Commendation for Dedication to COA Process

Lincoln Trail Cabinet for Families and Children

\section{7}

Commissioner's award for Outstanding Casework Kentucky's Cabinet for Families and Children

1994

Commendation of Excellence as Public Employee Presbyterian Child Welfare Agency

PROFESSIONAL AFFILIATIONS
Council on Social Work Education

National Association of Social Workers

Kentucky Association of State Employees

Kentucky Ten-ure Association 